


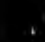




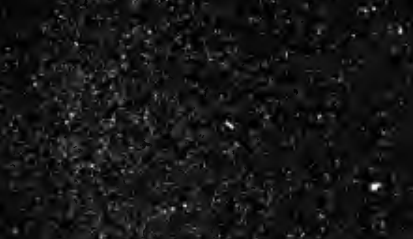

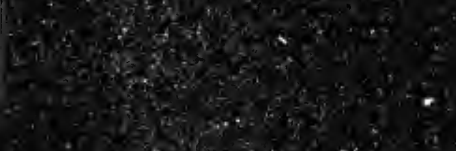

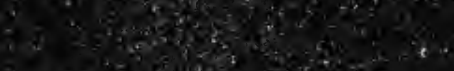

a

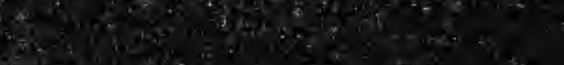

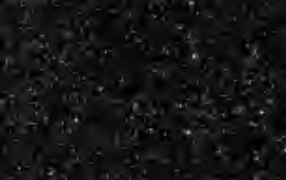

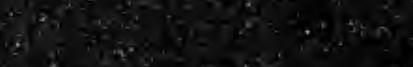

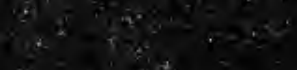

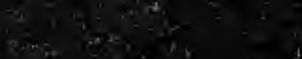

$x^{2} \rightarrow$

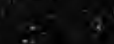



$$
1
$$$$
\text { s }
$$

$\mid$

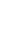

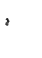




\section{A HANDBOOK OF CHRISTIAN ETHICS}


MESSRs. T. \& T. CLARK have just issted the First Volume of the great

\title{
ENCYCLOPAEDIA OF RELIGION AND ETHICS.
}

\author{
EDITED BY
}

\section{DR. JAMES HASTINGS.}

THE purpose of this Encyclopædia is to give a complete 1 account of Religion and Ethics so far as they are known. It will contain articles on every separate religious belief and practice, and on every ethical and philosophical idea and custom. Persons and places that have contributed to the history of Religion and morals will also be deseribed.

The Encyclopedia will cover a distinet department of knowledge. It is the department which has always exercised the greatest influence over men's lives, and its interest at least, if not its influence, is probably greater at the present time than ever. Within the scope of "Religion and Ethics" come all the questions that are most keenly debated in Psychology and in Soctalism, while the title will be used to embrace the whole of Theology and Purlosophy. Ethics and Morality will be handled as thoroughly as religion.

The work will be completed in Ten Volumes of about 900 pages each, Imperial 8 vo.

Price in Cloth Binding, 28s. net per Volume.

" Half Morocco, 33s. net per Volume.

Please ask for a full Prospectus of this monumental work. It may be had from any Bookseller, or free from the Publishers, on request.

T. \& T. Clark, Publisiners, $3^{8}$ George St., EDINBURGH. 


\section{A HANDBOOK}

OF

\section{CHRISTIAN ETHICS}

BY

J. CLARK MURRAY, LL.D., F.R.S.C.

EMERITUS PROFESSOR OF PHILOSOPHY, M'GILL UNIVERSITY

MONTREAL

Edinburgil : T. \& T. Clark, 38 George Street

I 908

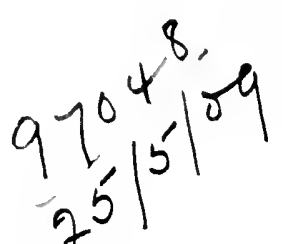


Printed by

Morrison \& GibB Limited,

FOR

T. \& T. CLARK, EDINBURGH.

LONDON : SIMPKIN, MARSIIALL, HANILTON, KENT, AND CO. LIMITED.

NEW YORK : CILARLES SCRIBNER'S SONS. 


\section{CON'TEN'TS}

INTRODUCTION $\quad . \quad \cdot \quad \cdot \quad \cdot \quad \cdot$
§1. Definition of Christian Ethics
1. Ethics is one of the normal sciences, as secking to define
the Chief Good or End of life, which furnishes a norm

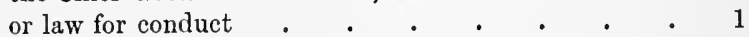

2. Christian Ethics approaches this problem from the Christian point of view. But this point of view is not arbitrary : it is rather a logical necessity. For the good of man carries thought necessarily to that universal good which is the cosmic end. Morality thus passes over into religion, and this movement of ethical thought is represented by Christian Ethics . . . .

§2. Rclation of Christian Ethics to Moral Philosophy .
Christian Ethios starts from the Christian ideal as a datum, Christian Ethics starts from the Christian ideal as a datum,
while Moral Philosophy must find its ideal by philosophical inquiry. But this does not form an absolute differentiation. For-

1. The Christian ideal has also to be found by methods of inquiry essentially philosophical . • .

2. The ideal reached by philosophical inquiry tends to an assimilation with the Christian. . . .

3. Both Christian Ethics and Moral Philosophy must indicate the application of their general ideal to the particular problems of practical life, and in doing so their methods are identical. For in all methods of research there is ultimately no appeal beyond reason . . . . . . . . 12

§ 3. Relation of Christian Ethics to Christian Dogmatics . . $\quad$ - 15

This is indicated by the dependence, especially in moral life-

1. Of theory on practice . . . . . . . 19

2. Of practice on theory . . . . . . . . 21

$\$ 4$. Jivision of the Seiencc-

It is here divided into four parts, treating of (1) the supreme Christian ideal; (2) that ideal in its subjective aspect; (3) that icleal in its objective aspect; (4) Methodolosy . 


\section{PAR'T I \\ THE SUPREME IDEAI, OF CHRISTIAN LIFE}

\section{CHAPTER I}

The Christian Ineal in the Abstract

Formal statement of the ideal.

§ 1. The equal Love of Neighbour and Self . . . . . . 27

Egoism and Altruism. Their reconciliation . . . 28

§ 2. Christian Lore as a Rational Habit. . . • • . . $\quad$ • 32

It is not a mere instinct, nor a mere transient impulse . 33

§ 3. The Christian Ideal revealed in Christ as the Realisation of God's

Will with regard to Man . . . . . . . 35

§ 4. The Christian Ideal as the Realisation of Man's Love to God . 36

\section{CHAPTER II}

\section{Evolution of the Christian IDeal}

\$1. General Tendency in the Expansion of the Moral Ideal . . 40

1. Its extent is widened . . . . . . . . . 41

2. Its intent is deepened (1) by its obligations being conceived, not as merely negatire, requiring to refrain from evil, but as positive, requiring to do good ; (2) by its rights being made less exacting . . . . . . . . 43

§ 2. Evolution of the Moral Ideal among the Hebrews . . . . 48

1. The Hebrew ideal was essentially religious, - the ideal of a religion which was (1) monotheistic, (2) a religion of moral life rather than of external nature . . .

2. The Hebrew ideal was a forecast of the Christian, because, being religious, that is, commanded by God, it (1) embraces humanity in its extent, (2) involves humanity in its intent

§3. Evolution of the Moral Ideal among the Greeks

The ideal of the Greeks was narrowed by their attitude towards Barbarians as well as towards slaves and even free labourers. Emancipation from the prejudices of this attitude by-

1. Philosoplical refletion seeking the foundation of moral law in the constitution of nature rather than in human convention . . . . . .

‥ Expansion of the idea of rightcousness so that it becane coextensive with all virtne, including especially equity, as corrective of statutory law, and liberality 
3. The recognition, espeeially among later Stoies, of all luman beings as children of one Eternal Father, and consequently the development of the new virtue of humanity as well as the eonsecration of the old virtues of hospitality and friendship . . .

\section{CHAPTER III}

The Moral Ideal revealed in the New Testament

\$ 1. The Moral Ideal in Christ's Teaching .
Christ's estimate of the infinite worth of the individual takes an altruistic aspect in anxiety to save the souls of others as well as one's own soul. The Sermon on the Mount elevates morality into the sphere of the spirit. It rejects the Retaliation-theory of social morality, in so far as this demands-

1. A physical equivalent for injury done

2. A mental equivalent,- -love for love, but also hate for hate. Love is made the universal obligation, even towarls those who hate. This injunetion is illustrated in the life as well as in the teaching of Christ

But was Christ's ideal, after all, that of a narrow nationalism, not that of humanitarianism?

In reply attention should be given to-

1. His preference of the title, The Son of Man . . 105

2. His attitude towards Samaritans and Gentiles . 106

3. Several humanitarian parables . . . . . 107

4. The real significance of two sayings, in which He seems to limit His work to the lost sheep of the House of Israel .

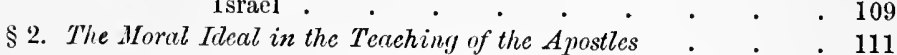

1. That of Paul, especially in 1 Cor. xiii. and in Rom. xiii. 8-10

2. That of Jolin .

\section{PAR'T II}

\section{THE CHRISTIAN IDEAL IN ITS SUBJECTIVE ASPECT}

\section{CHAPTER I}

\section{General Explanations}

Higher and lower self. Self-love distinguished from selfishness. Development of individual responsibility. Prominence given by 
Christ to the infinite worth of the individual soul as contrasted with the infinitesimal worth of all that is merely material. This conception in its speculative aspect . . . . . .

\section{CHAPTER II}

\section{The Natural State of Man in regard to Morality}

Opposite theories-

1. That man's nature is favourable to morality. The Stoics. Pelagius. Roussean and his followers . . . .

2. That man's nature is unfavourable to morality. The idea of an inborn inclination to sin among the Hebrews and the Pagans of the ancient world. St. Augustine. Calvinists and Jansenists. Hobbes . . . . . .

The two theories are not contradictory, but represent different aspects of human nature $\quad . \quad . \quad . \quad . \quad . \quad$.

The real facts are, that-

1. Natural impulses, not in themselves inimical to virtue, may become so if uncontrolled . . . . . .

2. The force of such impulses varies in different individuals, and has to be reckoned with in the moral culture of each .

3. In so far as they are natural, these impulses are non-moral, and cannot therefore be described as sinful. Original siı is a contradictory term . . . . . . . .

4. Morality implies that these impulses may be controlled by the will . . . . . . . . . .

\section{CHAPTER III}

\section{The Beginning of Chiristian Life}

General difficulty in the problem of beginnings. When a human being begins to apply reason to the guidance of conduct, he finds that it has been already overborne by natural impulses, that he has been acting unreasonably. Such action, in its highest aspect as conflicting with Supreme Reason, is a sin. Consequently at the very beginning of Christian life we are called to face the fact of-

§1. Sin of $\sin$ Christian Ethics can accept no view which tending to practical Fatalism, would weaken or paralyse moral eflort 
Sin has two aspects-one divine, as wholly opposed to the will of God; the other liuman, as proceeding wholly from the will of man . $. \quad . \quad . \quad$. Will, therefore, as no mere product of natural causation, has a certain infinitude, so that it cannot be coerced even by the Infinite. Accordingly, in the abstract a finite will may be coneeived as eternally opposed to the Infinite Will. This abstraction is embodied in the tragic conceptions of a Titanic or Satanic will, travestied in the immoralistic "overman" of modern playwrights, treated by Shakespeare as properly a theme for comedy in Falstaff . . . 159

\$2. Repentance or Conversion . . . . . . . . . 163

1. Negatively this change means becoming dead to the old life of $\sin$. $\quad . \quad . \quad . \quad . \quad . \quad . \quad . \quad 165$

2. Positively, being born again to a new life of holiness. 168

1. Such conversion may be sudden and violent, and its suddenness and violence are not out of analogy with familiar natural changes $\quad . \quad . \quad . \quad$. 170

2. But it is not necessarily or normally so . . . . 172

3. Thongh suddenness and violence are not withont value at times as giving force to the initial impulses of the now life . $. \quad . \quad . \quad . \quad . \quad .175$

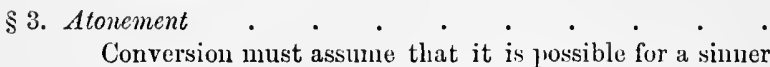
to abandon his sins; and this inplies, further, that the laws of nature, embodying the will of God, are favourable to such abandonment of sin. But abandonment and forgiveness of sin are identical. They both mean that the will of the sinner is brought into harmony with God's will, that he is at one with God. This harmony forms the essence of atonement in its ethical aspect . . . . .

\section{CHAPTER IV}

\section{Christian Charactel:}

Unity of virtues or excellences as being all moditicatious of a common type. Difliculty of classifying and naming the virtues. Aristotle's method of classification and nomenclature. Under any classilication or nomenclature the virtues must be viewed as the highest excellences of human nature in its various sphcres of activity 
§1. The Physical Basis of a Virtuous Life . . .
The attitude of extreme asceticism towards the borly is incompatible with religions intelligence, which must vicw it as a creation of God and as an organ or instrument for the service of the higher life. This is the view enforced in the New Testament . . .

§2. Development of Christian Virtue - $\cdot$.
Moral life as a conflict. The allied metaphor of sowing wild oats. Its truth and its perilous error. Moral life is a conflict with emotional impulses-

1. With those which embody the attractiveness of pleasure, the control of which constitutes Temperance. Aristotle's opinion that there is no vicious extreme of defeat in the love of enjoyment contradicted by Cynicism and asceticism. Christian temperance is not total abstinence from pleasure. Carlyle's description of Christianity as the worship of sorrow is one-sided. Quite as truly it may be called the worship of joy. Christian life gives full play to the joyful emotions. Among these hope takes a prominent rank with its outlook into inmortality, - an outlook that gathers clearness and force from the operation of the law of habit, which has led pagan thinkers to the belief that virtue, once acquired, becomes an inalienable possession, and Christian thinkers to emborly the same belief in the doctrine of the Perseverance of the saints. Nor is Christian sentiment inconsistent with good-humoured mirth, such as finds expression in genuine comic art .

2. With impulses which embody revulsion from pain, the control of which gives rise to two virtues. (1) This revulsiou may take the form of fear, and the control of fear is Courage. Deterrent disciplines, as playing on the passion of fear, are open to grave objections from their effects in pliysical, and in psyclical, as well as in moral, life. The fear of death as a motive in Christianity as compared with ancient Paganism. Lessing's view criticised. Cruclities of popular thought on the subject of death and its fear's. (2) The revulsion from pain may take the form of resentment, the 
control of which yields the gentler virtues.

PAGK Prominence of these in the Christian ideal as contrasted with that of Paganism. Origin and significance of the worship of the Virgin. Corrupting influence of irascibility on moral intelligence . . . . . . . 209

\$ 3. The Culmination of Christian Virtue . . . . . . 221

Christian virtue attains its highest r'each in that genuine wisdom which is identical with genuine knowledge and faith and love-the love of God as well as the love of man

\section{PART III}

\section{THE CHRISTIAN IDEAL IN ITS OBJECTIVE ASPECT}

\section{CHAPTER I}

\section{General Explanations}

The subjective aspect of virtue, in which it is viewed as personal culture, nust not be narrowed to a monastic ideal. There is no genuine culture which has not an objective or social aspect. .

The eonception of Society as an organism, in its truth as well as in its limitations, is recognised in Christian teaching . . . The forms of society essential to man as a moral intelligenceFamily, State, Church-have been gradually differentiated . .

\section{CHAPTER II}

\section{The Christian Churrei}

1. The variety of Churches is best appreciated historically, as giving expression to "the manifold wisdom of God which had to be made known through the Church," and as forming those kindly associations which are of powerful influence in practical life . . . . . . . . . .

2. These associations create obligations of loyalty, which imply

(1) not hostility to other Churches, but (2) effort for the well-

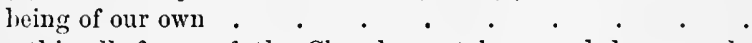

3. For this all forms of the Church must be regarded as merely means to an end. This does not allow, on the one hand, that one form is imperative to the exclusion of all others; or, on the other liand, that no forms at all are necessary. For (1) if there is to be association in religious life at all, men must meet for religious purposes ; and (2) this involves agreement as to times of meeting. Value of Sunday and other holy lays 
4. But all forms become useless, unless they serve the purpose for which they are designed; and that purpose is involved in the very nature of the Church as a purely spiritual society . .

\section{CHAPTER III}

\section{The Christian Family}

By its nature the family involves three relations among its members, -conjugal, parental and filial, brotherly and sisterly-

\$1. The Conjugal Relation . . . . . . .

While orginating in an instinetive emotion, this relation requires, for the higher aims of life, that the emotion shall be transmuted into a moral sentiment by the habitual will of man and wife to live for the good of each other . . . . . . .

The teaching of Jesus recognises that the sexual instinets form an integral part of human nature, embodying the will of the Creator, and that therefore marriage is a necessary institution of society .

But $\mathrm{He}$ also teaches that marriage is no common contract which can be dissolved at will by one or even by botl of the contracting parties, but is a bond so sacred as to be indissoluble exeept by a cause which nay be regarded as in its very nature a dissolution . . . . . . . . . 258

§ 2. The Parental and Filial Relation . . . . . . 262

This relation has obviously two sides-

1. The parental involves authority mellowed by affection. In Christian life, however, this affection is one, not of natural impulse, but of moral habit-the habitual will to care for the good of the children

2. The filial side is one of affection moulded by respect, and requires also to be trained into a moral habit, when, (1) in the interests of the individual, it trains habitual reverence for the moral imperative; (2) in the interests of soeiety, habitual reverence for the authority of Law. Signifieance of the fiftl commandment . . 264

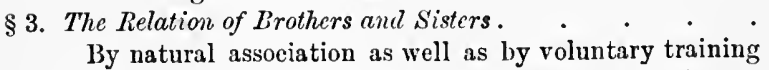
this relation contributes to the development of some of the finest sentiments of social morality . . .

But it requires eaution against relaxation of moral restraint ly familiarity. $. \quad . \quad . \quad . \quad . \quad$. 


\section{CHAPTER IV \\ Tie Christian State}

Though an ideal society would be one after the type of the Church, in which social obligations could be left to the spiritual power of individual conviction, yet, while men remain morally imperfect, it is nccessary to secure the external conditions required for human life. The State, which is designed to fulfil this function, is therefore " an ordinance of God" . . . . . . Notwithstanding this high function, it scems to be assumed at times that the highest morality is either not denianded, or, if demanded, is not possible in political life. Origin and unreasonableness of this assumption $. \quad . \quad . \quad . \quad . \quad . \quad$.

The economical aspect of social well-being. Jesus does not appreciate real wealth, but sees that it is to be secured by making, not it, but righteousness, the primary object . . . .

\section{PART IV}

\section{THE METHODOLOGY OF CHRISTIAN ETHICS}

\section{CHAPTER I}

\section{The Method of Moral Culture in general}

All sciences, so far as they aim at exact knowledge, have substantially the same method. But some are distinguished as practical by the fact that their ultimatc end is not mere knowledge or theory, but its application to practice. For the purposes of life in general, but more particularly of moral life, practical skill withont scientific theory is more valuable than scientific theory withont practical skill: But both ends are attained by the same method, by the training of habit. As habit is a growth from natural endowment-

1. It is necessary that training be adapted to the varieties of disposition with which men are endowed by naturc

2. Methodical training is encouraged by familiar facts which prove that it can not only developo natural dispositions, but also check or even eradicate them ly the development of comnteractive habits . $\cdot \cdot$. $\cdot$.

3. Moral training, therefore, follows the method by which habits are formed, and its success depends (1) on the force of the initial impulse to their formation; (2) on the continued repetition of the actions which form moral habits. This requires the frequent performance of exercises 
prescribed for this speeial purpose. Such exercises constitute what we understand by discipline, learuing, training, education, and terms of similar purport .

Singular lack of such exercises in our educational systems, when contrasted with the exercises provided for physical and intellectual culture

\section{CHAPTER II}

Special Methods of Moral Culture: their Dangeis and Safegualids

Specific moral exercises must be designed mainly to develope power of will. They give an intelligible meaning to the doctrine in regard to works of supererogation. Though lacking in our educational systems, they have never been ignored altogether, at least in religions societies. Fasts and penances, truly understood, form an admirable discipline for training the will to resist both the attraction of pleasure and the revulsion from pain in the performance of duty . $. \quad . \quad . \quad . \quad . \quad$.

Such diseiplines cannot be enforced by external anthority ; for, to be effective, they must be (1) perfectly voluntary, (2) perfectly secret, that is, free from any corrupting inflnence of ostentation .

This is merely another way of saying that snch disciplines are merely means to an end, and must always be subordinated to tlat end. But all through educational work the end is frequently sacrificed

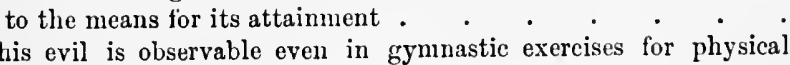
well-being; for these, especially when they take the form of athletic contests, often become, by exhaustive strain, detrimental to health and strength. Aristotle's observation on the subject . By the same mistake a reasonable askesis may degenerate into an unreasonable aseeticism which looks upon the renmeiation of innocent pleasure or the endurance of needless pain as if it were

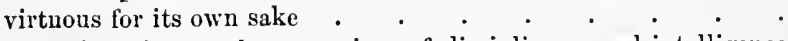

To guard against such perversions of disciphine, moral intelligence must be cnltivated. But the disciplines for this purpose are liable to the same abuse. Casuistry. $\Lambda$ gainst such abuse the best safeguard is to keep before the mind what is the ultiniate eud of all earnest intellectnal work, - to reach the point of view of Perfect Intelligence. What is implied in the habituation of the mind to this point of view . . . . . . . . 


\section{A HANDBOOK OF CHRISTIAN ETHICS}

\section{INTRODUCTION}

\section{§ 1. DEFINITION OF CHRISTIAN ETHICS}

THE science of Christian Ethics is defined by its name. It is a science of Ethics, but of Ethics interpreted in the light of the Christian ideal. The name thus calls for an explanation of two points-(1) the drift of Ethics in general; (2) the modification of Ethics by the peculiar ideal of Christianity.

1. Ethics belongs to that class of sciences which have sometimes been characterised as normal or normative. ${ }^{1}$ These stand in contrast with sciences which are properly styled natural. A natural science, in the simplest meaning of the term, deals with the laws in accordance with which phenomena actually recur. But man's life is not completely explained by these laws. $\mathrm{He}$ is capable of proposing to himself ends in life, and of directing his conduct with a view to the attainment of these. Such an end thus furnishes a norm for the regulation of life, and the laws which must be observed for the attainment of such an end form subjects for a normal science. Every sphere of life may, therefore,

${ }^{1}$ Less happily by Sir W. Hamilton as nomological. See his Lectures on Metaphysics, vol. i. pp. 122-124. 


\section{A HANDBOOK OF CHRISTIAN ETHICS}

have a normal science of its own, according to the end which it is designed to serve. We may give a scientific aim even to the lower activities of sentient life in such studies as Gastronomy, to its higher activities in the Theory of Music and the Theory of Colours; while more important activities of life find their norm in Mechanics, Esthetics, Logic, Rhetoric, and similar sciences. But these studies deal merely with limited spheres of human conduct, and they imply some end in which all are comprehended-an end to which all the activities of life ultimately point. This end, with its implications, forms the subject of Ethics.

The problem of Ethics admits of being described from various points of view. In the first place, as we have seen, it is the problem of finding the chief end of life, to which all particular ends must be subordinated as merely means. Accordingly from the very beginning of ethical inquiry this has been a familiar description of its aim. It is from the Greeks that the description is derived. From the first they made the task of Ethics

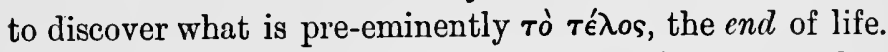

But, in the second place, for every living thing what is conceived as the end of life must be a condition which is so completely in harmony with its nature as to produce its highest possible well-being. But such a condition is what is meant by good in the fullest sense of the term, just as evil is the proper description of anything which interferes with the well-being of a creature, defeating the very end of its existence. Thus the problem of Ethics assumed auother phase; it came to be viewed as seeking the true good of man. And here again the Greeks have been our guides. They identified the end of life with the good of life, ro a aratóv, - summum bonum, as it was rendered in Latin Philosophy. 


\section{INTRODUCTION}

Then, in the third place, we have also seen that the end which a man has in view furnishes a norm for the guidance of his conduct. In other words, it imposes on him a law which he must obey in order to its attainment. But if there is some supreme good which forms the chief end of life, there must be some supreme law, some universal principle, for the government of human conduct; and the problem of Ethics may be said to be the discovery of that principle.

2. This problem is in Christian Ethics approached from the Christian point of view. But the modification thus imposed on the general science of Ethics is far from being altogether arbitrary. It is, on the contrary, rather a logical necessity of ethical speculation. For the good of man, which forms the chief end of his existence and the supreme law for the regulation of his conduct, cannot be anything out of harmony with the general order of the universe in which he lives. His life is, in fact, a perpetual interaction between the forces which are at his own command and those of the external world. Cousequently his good is a joint result of his own activity and that of the universal order. Thus the problem of man's chief end cannot be solved without going beyond himself. It is inextricably bound up with the problem of a cosmic end, an end to which the whole evolution of nature points. It is therefore by a necessary movement of thought that morality passes over into religion, and it is this movement that Christian Ethics represents. Christian Ethics is essentially a religious system. It might appear as if we were thus plunged into all the bewilderment which some associate with the effort to find a satisfactory definition of religion. ${ }^{1}$ But this is by no means necessary. Whether or not the

1 Professor James gives an extravagant expression to the difficulty of such efforts in his Varieties of Religious Experience, pp. 26-27. 
effort is as futile as it has sometimes been represented, it is one which we are not called to undertake. For we have to do, not with religion in the abstract, but with the religion known as Christianity; and that must mean at least such an attitude of the finite mind towards the Infinite as finds its highest embodiment or incarnation in Christ.

The Ethics of Christianity must, of course, run along lines which at many points are parallel to those of other systems. In fact, although Christianity as a religion was from the first essentially and intensely ethical, its Ethics did not take a systematic form from influences originating within itself. Early Christian literature, indeed, is almost entirely occupied with the elucidation and enforcement of ethical precepts. This dominant tone was struck by the writers of the New Testament, and continues to vibrate in post-canonical writings. It has been remarked that the early apologists lead their defence mainly and most effectively along ethical lines. ${ }^{1}$ In this way the early records of the Church furnish many a valuable hint for the scientific treatment of the problems of Christian life. But it was not till Christianity had won the assent of minds trained by the scientific methods of Greek Philosophy, that any attempt was made to embody its ethical teaching in the form of a scientific system. The result was that the systematic form imparted to Christian Ethics is one which had become to a large extent traditional in the ethical schools of Greece. This first appears, where it was naturally to be expected, in the earliest great school of Christian thought founded by the Greek Fathers of Alexandria. ${ }^{2}$

${ }^{1}$ See Ziegler's Geschichte der Christlichen Ethik, p. 157.

2 There must have been a Christian school at Antioch even in Panl's

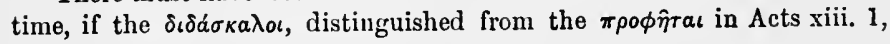


In the writings of Clement, which belong to the close of the second and the beginning of the third century, there are numerous discussions on ethical problems both of a speculative and of a practical character; and these are always conducted in the methods and under the categories which had grown familiar to him from his intimate acquaintance with Greek literature. But Clement never seems to have traversed the field of Ethics as a whole with the view of reducing it to a scientific system. The first attempt of this kind within the Christian Church of which we have any record, was that of Origen, Clement's successor in the Alexandrine school. Of this attempt we have unfortunately merely a brief sketch by an admiring pupil, Gregory Thaumaturgus. From Gregory's Oratio Panegyrica it appears that Origen carried his pupils through a complete course of Philosophy as then understood. Beginning with Logic (chap. vii.) he advanced to Physics, Geometry and Astronomy (chap. viii.), and finished with Ethics, to which he gave special prominence (chaps. ix.-xii.). In his treatment of this science he followed the fourfold classification of the virtues which had been originally devoloped by Plato, which had been adopted by Stoics and Epicureans alike, and which had become current generally in the ethical literature of the ancient world. These he ennobled with a religious title by styling them

are to be understood in the strict sense of the term. There is evidence, in fact, that schools of some sort for the instruction of catechumens arose at an early period in all the great centres of Christian life. That life, therefore, at least from the beginning of its expansion among the Greeks, came under those intellectual influences which endeavour to find a rational system in all things. But none of the early schools attained the historical eminence of that in Alexandria. At a later period, however, in the fourth century, the Antiochene school rose into prominence as a rival and even opponent of the Alexandrine. Sce Hatch's Lectures on the Influence of Greek Ideas and Usages upon the Christian Church, pp. 81-82. 


\section{A HANDBOOK OF CHRISTIAN ETHICS}

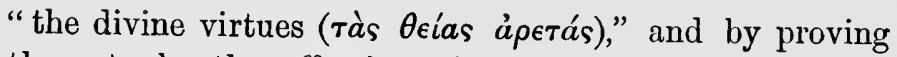

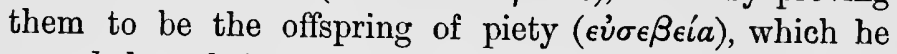
regarded as their common mother $\left(\mu \eta^{\prime} \tau \eta \rho\right)$, the beginning and the end ( $\dot{a} \rho \chi \grave{\eta} \kappa a i$ $\left.\tau \epsilon \lambda \epsilon v \tau \eta^{\prime}\right)$ of them all. ${ }^{1}$

But the first systematic work on Christian Ethics which has come down to us dates from an age more than a century after Origen. It is the De Officiis Ministrorum of Ambrose (A.D. 340-397). By its title this work professes to explain merely the duties of ecclesiastical ministry; yet, as every Christian is in a sense a minister of the Church, it is in reality a manual on the Ethics of Christian life in general. Its title also, and still more its method, form an obvious reminder of Cicero's $D c$ Officiis, as this itself is professedly a compilation from an earlier Greek treatise by the Stoic Panætius. Like Origen, Ambrose follows the generally accepted classification of the virtues, a classification which gives its form to Cicero's treatise also. In another work of Ambrose (Expositio Evang. sec. Lucam, v. 62), the four virtues of this classification are distinguished by the title of cardinal; and this name has held a place in ethical nomenclature ever since. Under Ambrose's treatment the virtues receive a certain Christian colouring from being enforced by quotations from the Bible rather than from pagan authors, and illustrated by examples from Biblical history rather than from the history of Greece and Rome. But this does not modify the form in which the science is treated; it merely alters illustrative details.

There is, of course, no reason for depreciating the service thus rendered to Christianity by the philosophical culture of Greece. That sorvice cannot, in fact, be easily

${ }^{1}$ In his sketch of Origen's ethical teaching, Ziegler (Gcschichte der Christlichen Ethik, pp. 149-153) has unfortunately overlooked this account by Gregory. 
over-estimated. For no teaching of religion or morality can secure the full and lasting assent of the world's intelligence without satisfying the demands of scientific method; and that method could be imparted to Christian teaching at first only by the Greeks. But Greek method, though requiring some systematic form in the treatment of truth, did not necessarily impose any particular form; and in general the adoption, for any subject, of a form from a foreign source is apt to be prejudicial to its treatment. The scientific development of a subject partakes in some measure of the nature of organic growth. Its distinctive form, therefore, ought to be an outgrowth of the subject itself, moulded by its own peculiar spirit. This holds eminently of Christian Ethics. From whatever point of view Christianity may be regarded, even one that is purely historical, the fact forced upon us is the creative power of a great Personality entering into the current of human history, and by His pre-eminent spiritual force giving a direction to the moral life of men. But this means that the moral life of Christendom can be understood only by reference to the creative power of this Personality. It is therefore clearly unscientific to construct a scientific theory of that life in any other method than by direct reference to His personal influence. If there is any place at all for a distinctive science of Christian Ethics, that place can be vindicated only by starting from the ethical ideal embodied in Christ, and working out from that a code of morality for the practical guidance of Christian life. Even if it had not been implied in the whole significance of the Master's teaching and life, it came to be clearly recognised from the first as a rule of conduct in the Christian community, that He had left an example which men should follow (1 Pet. ii. 21; compare Matt. xvi. 24 and par.). 'Tis strange that 


\section{A HANDBOOK OF CHRISTIAN ETHICS}

the value of this principle should not have been recognised in application to moral science as well as to moral action. This is all the more surprising when we consider the attitude towards Christ of those who do not profess Christianity in any orthodox sense. All through the history of Christendom this attitude has been remarkable. For our purposes one of the most significant expressions of this attitude is a well-known utterance of Mr. J. S. Mill,-an utterance all the more significant that its language seems to glow with a warmth somewhat unusual in the author's style. "The most valuable part of the effect upon character, which Christianity has produced by holding up in a Divine Person a standard of excellence and a model for imitation, is available, even to the absolute unbeliever, and can never be lost to humanity. . . . Religion cannot be said to have made a bad choice in pitching on this man as the ideal representative and guide of humanity; nor even now would it be easy, even for an unbeliever, to find a better translation of the rule of virtue from the abstract into the concrete than to endeavour so to live that Christ would approve our life." 1

Now, if such is the view of one who looked upon Christ merely as an useful ideal for the inspiration and guidance of human conduct, then certainly that ideal may reasonably be taken by the Christian moralist as the foundation of his science. Our task, therefore, is to construct the science of moral life in accordance with the ideal of Christ. Such a construction alone can vindicate for Christian Ethics an independent place among the sciences, differentiating it from Moral Philosophy as commonly and properly understood. But the relation of these two sciences calls for fuller consideration. 


\section{§ 2. RELATION OF CHRISTIAN ETHICS TO MORAL PHILOSOPHY}

Christian Ethics, we have just seen, founds on the ideal of Christ. It takes that ideal as a datum, something granted to begin with. On the other hand, a philosophical system of Ethics is not allowed to assume its ideal, but must discover it by the ordinary methods of philosophical inquiry. But this does not form an absolute differentiation of the two sciences. They cannot, in fact, be separated by any hard and fast line of demarcation, and this for various reasons.

1. In the first place, the ethical ideal of Christianity is not wholly free from the problematic character which attaches to the ethical ideal of all humanity. For it need not be said that we have no authoritative exposition of the Christian ideal in such a form as science demands. The reason of this is not far to seek. The work of Christ was to create the Christian life, not to teach a scientific theory of it. His work differed from that of a scientific teacher as the creative work in nature differs from the natural sciences by which it is explained. All science must be furnished with facts, and its task is to give a rational explanation of these. It is the work of Christ in quickening the moral life of the world that has furnished the facts upon which our science is based. That work, therefore, was designed to stimulate action rather than to formulate thought.

It is true that this stimulation came in a large measure from the teaching of Christ, and it is by no means a superfluous task to recall the prominence which is given to this aspect of His life in all the canonical Gospels. ${ }^{1}$

1 This is brought out with some detail in an article on "The Ethics of the Gospels" by A. C. Pigou of King's College, Cambridge, in The International Journal of Ethics for April 1907. 


\section{IO A HANDBOOK OF CHRISTIAN ETHICS}

There is, in fact, ground for believing that the primitive memoirs to which St. Luke alludes (Luke i. 1-2), and the existence of which is indicated by St. Paul (Acts xx. 35) as well as by other evidence, were

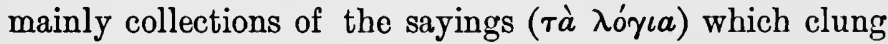
to the memory of men as the most precious legacy of the Master's teaching. Now it is sufficient here to point out that, while His teaching has a very characteristic method of its own, this method is not that of the scientific expositor. Accordingly His conception of the general principle which $\mathrm{He}$ instilled into the moral life of men as well as of its particular applications has to be gathered from a collation of a great variety of statements, and gathered by the same methods of research that are employed in Moral Philosophy.

A similar remark applies to the apostolic writings which form a large part of the New Testament. These are almost entirely occupied with the discussion of ethical problems under the guidance of the new spirit which had been awakened by the Master's teaching. But here also there is no attempt at a scientific method of treatment or a scientific formulation of its results. We are supplied with numerous data pointing to the growth of distinctively Christian forms of thought and sentiment on ethical questions, the growth of a characteristic Christian $\dot{\eta} \theta$ os, eine Christliche Sitte. But these data in the moral life of the primitive Christian community require for their correct interpretation a constant regard for the peculiar condition in which that community was placed. ${ }^{1}$ Consequently, for the construction of a scientific system of Christian Ethics they offer essentially the same problem as that which is presented to the moral philosopher by the facts which constitute the moral

1 An elaborate study of the moral life of the primitive Churches is Die Urchristlichen G'remeindcn: Sittengeschichtliche Bilder, by Dobschütz. 
life of the world at large. It was natural, therefore, that, as we have seen, the first Christian moralists followed the methods that were prevalent in the Moral Philosophy of their time.

2. On the one side, then, Christian Ethics tends to an assimilation with Moral Philosophy. But, on the other side, Moral Philosophy tends to an assimilation with Christian Ethics. It is true there are those to whom Christian Ethics possesses only an historical interest, who regard the Christian ideal as nothing more than a transitory phase which is passing, if it has not already passed, away in the evolution of moral life upon our planet. This, indeed, is not a common attitude. It is not on the side of its Ethics that Christianity is usually attacked. On the contrary, as already mentioned, there are dissentients from Christianity who contend that its ethical value will never be lost, even if its historical foundations be undermined; and the Churches have often to bear a well-aimed blow from an outsider because of their failure to live up to their own ideal in which he himself believes. Among those, however, who approach the problem of Ethics without any hostility to Christian presuppositions, but in impartial independence on them, there is a remarkable general tendency towards a solution which is in essential harmony with the Christian ideal. Accordingly, as will appear in the sequel, the movement towards this ideal may be traced in the leading ethical systems even of pre-Christian Philosophy; while many who, like Count Tolstoi, dissent in various ways from the common interpretation of Christian morality, yet hold that their interpretation alone represents the real significance of Christ's teaching. ${ }^{1}$

1 Occasionally essays pointing to a reconciliation of recent antiChristian teaching with the essential drift of Christian Ethies take a form of curious ingenuity. Thus in Bernard Shaw's Man and Superman 


\section{2 A HANDBOOK OF CHRISTIAN ETHICS}

3. But these facts do not form the only rapprochement between Moral Philosophy and Christian Ethics. For the largest field of all ethical science is not that which searches after the supreme principle of moral life in its abstract universality, but rather that which applies this principle to the guidance of men under the concrete conditions of daily life. But such application of a general principle to particular cases must be conducted on the same method in every region of inquiry; and consequently in this department at least the method of Christian Ethics must be substantially identical with that of Moral Philosophy. And what is that method? It is essentially the rational, as distinguished from any irrational, method of inquiry. That is to say, it is the method imposed upon all work of reason by the essential nature of reason itself. For we can never in any inquiry escape from the authoritative demands of the inquiring reason. In some minds there seems to be a confusion creating the belief that it is possible to find some authority external and superior to reason. Such an authority, whatever may be the prestige of antiquity or the sentiment of veneration with which it is invested, involves a contradiction in its very nature. For, in the first place, its claim upon the subjection of reason must

(p. xxxii) occurs the following: "It may seem a long step from Bunyan to Nietzsche, but the difference between their conclusions is purely formal. Bunyan's perception that righteousness is filthy rags, his scorn of Mr. Legality in the village of Morality, his defiance of the Church as the supplanter of religion, his insistence on courage as the virtue of virtues, his estimate of the career of the conventionally respectable and sensible Mr. Worldly Wiseman as no better than the life and death of Mr. Badman : all this, expressed by Bunyan in the terms of a tinker's theology, is what Nietzsche has expressed in terms of post-Darwinian, post-Schopenhauerian philosophy, Wagner in terms of polytheistic mythology, and Ibsen in terms of mid-nineteenth century dramaturgy." And so on. Nietzsche would certainly be more astounded than any man at this attempt to give a Christian aspect to his ethical teaching. 
take the form of an appeal to the reason which it would subject. But such an appeal obviously recognises the authority of the reason to which the appeal is made. In the very act of claiming that reason is subject to its demands, an external authority must acknowledge that it is itself subject to the demands of reason. But there is a further contradiction in the conception of an external authority claiming absolute subjection from reasonable beings. The demands of such an authority must be embodied in some intelligible form. All intelligible utterances, however, imply an intelligent being for their interpretation; and the interpretation of any utterance depends on the state of intelligence in the being by whom it is interpreted. Even if there is any sense in which infallibility may be claimed for an authority independent of reason, no infallibility has ever been claimed for the persons by whom the utterances of such an authority are to be interpreted. The fallibility of interpretation in the case of ancient oracles had become a byword among the Greeks. The history of the Christian Church, even during the period of the highest prestige to which the Papacy attained, proves that variations have not, as a controversial work of Bossuet seems to imply, been confined to Protestantism. And if any Protestant makes the Bible an oracular utterance with an infallible meaning, he is compelled to face a bewildering divergence in the interpretation of his oracle even by accomplished Biblical scholars. ${ }^{1}$ But even if such a view did not involve a complete misapprehension with regard to the sacred books themselves, it ignores the essential significance of the great movement out of which Protestantism took its origin.

1 There is an often quoted satirical distich of Werenfels: "Hic liber est in quo quærit sua dogmata quisque, Invenit et pariter dogmata quisque sua." 


\section{4 A HANDBOOK OF CHRISTIAN ETHICS}

For that movement meant nothing if it was not at least a reassertion of the elementary truth which has been recognised by all great thinkers, Christian and pagan alike,-the supreme authority of reason in all the problems of life.

It is, therefore, not surprising that Christian Ethics shows another point of analogy with Moral Philosophy. Even though there may be substantial agreement among Christian moralists in regard to the supreme principle of moral life, they have yet diverged widely in the solution of its more special problems. The varying phases of Christian life carry their lesson for us in the study of Christian Ethics. They call for the exercise of a broad intellectual and spiritual sympathy in order to a truly scientific appreciation of the facts with which we have to deal. For we cannot shut our eyes to the fact that Christian life is more or less profoundly modified by the influences amid which men live. Such modifications are readily detected in the comparative study of communities, of social circles, in which the conditions of life are different. Even in spheres of Christian society that are contemporary with one another we find marked variations, and these are in general more conspicuously marked when we compare different periods. For Christian life, like all life, is a process of growth or development-a process of evolution, to use the current language of science; and it is a noteworthy fact that, in His descriptions of Christian life, the Master Himself is fond of drawing His illustrations from the processes of growth in nature. But this implies that Christian Ethics, in seeking to give a scientific interpretation of Christian life, must go through a progress similar to that of the life which it interprets. The problems of our science, therefore, change from age to age. This makes it an useless waste of scientific 
labour to occupy ourselves with problems solved long ago, as if they were still difficulties of our time. Yet the value of the historical study of Christian Ethics in the spirit of the critic rather than of the advocate must not be overlooked. For the Christian as well as for every theist, the evolution of thought on all problems-surely also the evolution of the whole universe-is essentially a rational process, a process in which the Universal Reason reveals Himself throughout the ages. Accordingly the Christian moralist may often find guidance in solving the ethical problems of his own day by studying the moral history of the past from which these problems have been evolved. And as in all life the higher organisms in process of generation seem to pass through the stages which lower organisms represent, so it would appear that for men the highest intellectual life is reached by passing, in some cases rapidly, in some more slowly, through its lower phases. It is this fact that creates our deepest interest in the spiritual struggles of the past, through which our intellectual and moral civilisation has been won. Apart from this nothing is gained, the sight is rather apt to be obscured or blinded, and the spirit to be stifled by stirring again the dust of controversies that have been fought out long ago.

\section{§ 3. RELATION OF CHRISTIAN ETHICS TO CHRISTIAN DOGMATICS}

It thus appears that the ethical teachers of Christendom have not always been at one in their views with regard to particular rules of conduct at least. This means that different doctrines have been entertained in the domain of Christian Ethics as well as in that which is known by the distinctive name of Dogmatics. The two sciences are thus brought into a certain relation 


\section{I6 A HANDBOOK OF CHRISTIAN ETHICS}

or analogy. They are both, indeed, exponents of Christian life, each representing a different phase,--Dogmatics the contemplative or meditative, Ethics the active or practical. This connection of the sciences, however, may be carried too far. It may be made to imply an identification which would logically abolish the distinction between all the branches of Christian Theology. All over the field of the sciences, in fact, their boundary lines would disappear if we dwelt merely on their connections and ignored their differences. If a special science is not to lose its aim by wandering into all the neighbouring fields which skirt its borders, it must concentrate attention on its own domain. Every competent guide over that domain will indicate with sufficient clearness any wider outlook that may be necessary for successful guidance. But the expositor of a special science confounds his task with that of the philosopher when he obscures the distinctive character of his own study in the discussion of its connections with the whole cyclopedia of the sciences. Recent Christian moralists have protested against any obliteration of the distinction between Ethics and Dogmatics. ${ }^{1}$ This confusion is charged by Dorner specially against Schleiermacher and Nitzsch, but not altogether with justice. It is quite true that they both regard the two sciences as merely different branches of Christian doctrine; but, while thus emphasising the connection of the two, they by no means ignore their differences. ${ }^{2}$

1 See Dorner's System of Christian Ethics, \$ 1; Wuttke's Christian Ethics, vol. i. pp. 21-27 ; Martensen's Christian Ethics, vol. ii. pp. 35-45. These references are to the English translations.

"Schleiermacher has an elaborate discussion at the opening of his Christliche Sitte (Werke, Abth. i. Bd. xii. pp. 1-24). Nitzsch is briefer. See his System der Christlichen Lchre, $\S 3$. Wuttke's criticism of Rothe overlooks the fact that the Theologische Ethik is not a mere handbook of Christian Ethies, but a work of far larger speculative range. 
The truth is that the intimate connection of the two studies cannot be ignored without harm to both. It is sheer intellectual confusion to talk of a creedless morality. The confusion draws its origin perhaps from a shallow interpretation of an old fashion in psychological language, which describes mental life as if it were a play of different "faculties" operating independently of one another. An absolutely creedless morality would imply that there might be an activity of mind which was volitional or emotional without being intellectual at all, as if an intelligent being, as such, might act from a mere impulse of emotion or will without any direction whatever from intelligence. But not only are emotional impulses by themselves merely forces in human nature; will also, abstracted from intelligence, is reduced to the rank of a natural force. But forces, conceived as purely natural, are absolutely non-moral. Every moral action is an intelligent action. It flows from the intelligent assent of the agent to some principle which he believes to be good. It implies, therefore, faith in that principle, and the grandeur of moral action must in general be in direct proportion to the intensity of faith in the articles of its creed.

This fact has been specially recognised by all the great thinkers, from Pyrrho to Hume, who are classed as philosophical sceptics. It comes out with peculiar clearness in the teaching of the ancient representatives of this school. Some of them, indeed, are described in popular anecdote as being so wedded to their theory of the universal doubtfulness of things, that they would not turn out of the way to avoid any danger lest they might be supposed to admit the certainty of the danger avoided. Stories of this drift may fairly be taken as representing merely the vulgar gossip of minds that cannot penetrate to the real meaning of a speculative theory, and interpret it according to its most superficial reading. The sceptical 


\section{8 A HANDBOOK OF CHRISTIAN ETHICS}

thinkers of the ancient world were no fools. They knew that life is action, that in order to live a man must act, and in order to act must believe in the reality of the world which his action is to modify. They taught, therefore, that, however sceptical a man may be in the region of pure speculation, yet in order to live at all it is necessary to have some principle for guidance; and in different schools they assumed either the laws and usages of society, or some abstract criterion of probability as sufficient for the regulation of conduct.

Among modern sceptics a similar attitude has been maintained. Descartes started from the conviction that the mind can be purified from prejudice only by a doubt that is unsparing in its universality. Yet for the very success of such a method he held that the doubt must be limited to speculative life. In practical affairs, therefore, he remained one of the most conservative of men. In like manner Hume may not unfairly be described as a somewhat bigoted Tory in reference to the social and political problems of his time, and the prejudices of an old-fashioned British Toryism shine through every page of his History in striking, sometimes amusing, contrast with the revolutionary radicalism of his speculations.

In this respect the procedure of moral life is analogous with that of science, for morality is an application to practical conduct of the same reason which directs the conduct of scientific research. No genuine scientific work can be doue by merely groping in the dark. In theories of scientific method the day has gone by when it was expected that new truths would leap to light as a simple result of good luck in the collection and tabulation of facts. Scientific progress is made only by minds that have been trained to know in what direction fresh discoveries may be expected. Such minds are guided by some guess, surmise, conjecture - some 
anticipatory hypothesis without which the work of investigation would be aimless. The hypothesis at this stage is regarded as an anticipation. In the language of contemporary science it is commonly described as "a working hypothesis." It is what Kant calls a regulative, not a constitutive principle. This feature of scientific method has an import in Ethics also, and that in two ways. For-

1. On one side, we have seen that science is prevented from evaporating into a region of unsubstantial theory only by practical verifications which keep it on the solid foundation of fact. Even in the exact sciences the most rigid mathematical deduction must submit to the test of observation or experiment. The brilliant mathematical triumph of Adams and Leverrier, by which they wrung from nature the secret of the planet Neptune, did not satisfy the scientific world till the telescope was turned to the point indicated by their calculations, and brought the joy which comes to

\section{" the watcher of the skies}

When a new planet swims into his ken."

But observations and experiments are actions; they are methods by which the observer or experimentalist finds whether he can act on his theoretical deductions. Such practical methods, indeed, are sometimes held to be the only real and ultimate test of all truth. This contention has within recent years developed into a philosophical theory under the name of Pragmatism, which claims among its adherents not a few names in the Old World as well as in the New. Whatever may be said of this theory as a whole, it suggests a significant relation between Ethics and Dogmatics. May it not be that the dogmas of Christian faith, like the theories of other sciences, find their vindication in practical tests? 
Kant, it will be remembered, held that by speculation divorced from the practical conduct of life, reason is incapable of reaching any reality that transcends sensible experience; but that practical reason, imposing a categorical imperative-an unconditional command-upon conduct, postulates the three great supersensible realities, God, Freedom, Immortality, as the condition under which alone that imperative can be realised. ${ }^{1}$ On the same principle, a more vigorous form might be given to Christian Dogmatics if an attempt were made to reconstruct it by seeking for those dogmas, and those alone, which are postulated as imperative requirements of Christian life. If a genuine Christian life can be shown to be impossible except by faith in certain dogmas, that fact should be taken as a more triumphant vindication of these than could be achieved by the most ingenious speculative dialectic. But such vindication means the practical experience which is gained by the

${ }^{1}$ In the same line of thought the author of the Epistle to the Hebrews makes the existence of God as a Moral Governor an indispensable postulate of Christian life: "He that cometh to God must believe that He exists, and is rewarder of them that seck after Him" (xi. 6). Sometimes the same conclusion is reached from an opposite point of view, by starting with a rejection of Christian morality, and landing in a rejection of the fundamental articles of Christian faith as bound up with the morality by an indissoluble connection. Of those who, like George Eliot, cling to the one while letting the other go, Nietzsche remarks: "They are quit of the Christian God, and believe themselves all the more bound to hold fast Christian morality : this is an English consistency, and we will not take it amiss in moral little women $\dot{a}$ la Eliot. In England, for every trivial emancipation from Theology one must, in fear-inspiring fashion, recover honour as a moral fanatic. That is the penance that has to be paid there :-For other people like us it is different. If Christian fiith is given up, the right to Christian morality is pulled from under the feet. This is not quite evident; it has always to be mado clear agrain in spite of English shallow-pates. Christianity is a system, a logieally connected and integral view of things. Break off one of the leading ideas-the belief in God-and the whole goes to pieces." See Gützendammerung in Werke, vol. viii. p. 120. 
application of Christian truth in the conduct of - life. Accordingly all great moralists have emphasised the value of virtuous living for the enlightenment of moral intelligence, and have sounded a warning against the inevitable darkening of moral intelligence which results from vicious ignoring of moral law in practical life. In his cool scientific method, Aristotle is peculiarly explicit and earnest in insisting on the necessity of moral training for the proper study of Ethics. ${ }^{1}$ That is therefore a thoroughly scientific appeal which our Lord Himself makes to test the truth-the divine sanctionof His teaching: "If any man is willing to do the will of God, he shall know of My teaching whether it be of God or I speak of Myself." 2

2. But this will probably involve, on the other side, an important simplification of Dogmatics. Theology cannot escape the influences of the scientific spirit. That spirit demands that every doctrine claiming the assent of scientific intelligence shall submit to practical tests. Any theory, therefore, which is beyond the roach of such tests, which does not admit of being verified by experiment or observation, may continue to furnish gratification for idle curiosity, but does not become part of the scientific faith of the world. In the same way the Christian world is becoming indifferent to

1 " He who is to study properly things honourable and just, and political subjects in general, ought to have been well trained in his habits" (Eth. Nic. i. 4, 7 ; cf. i. 3, 5-7). The reason assigned for this, $\dot{\alpha} \rho \chi \grave{\eta} \gamma \dot{\alpha} \rho \tau \delta \delta \delta$, is one of those curt Aristotelian sayings of which the interpretation forms a subject of controversy. But under any possible interpretation it asserts the importance of knowing the facts of moral experience in order to the successful study of moral and political science. It is surely matter of surprise that this slould require assertion. It is as if one were called to show that it is necessary to know something of the facts of nature in order to the profitable study of any branch of natural science.

${ }^{2}$ John vii. 17. 
religious doctrines which cannot claim more than a speculative interest. It will not, indeed, impose futile and unreasonable restrictions upon the legitimate exercise of speculative intelligence in the domain of religion any more than in that of science. But there is evidently a growing revolt against the enforcement of any injunction to believe a doctrine which is proved by experience to be no indispensable article of Christian faith, no integral part of the faith by which Christian living is sustained.

Whether this revolt is to reconstruct the whole system of Christian Dogmatics or not, it must at least form a dominant issue in the construction of Christian Ethics. To this we now proceed.

\section{§ 4. DIVISION OF THE SCIENCE}

In the arrangement of the different topics to be discussed in a work like this, there is room for considerable variety of choice, and in general some advantage may be pleaded for any arrangement preferred. There is, therefore, little to be gained, as a rule, by controversy as to the rival advantages of different arrangements. Each arrangement may be left to vindicate itself by the manner in which it lays the whole subject before the reader's mind.

Here it is proposed to divide the subject into four parts. The first will be occupied with an inquiry into the general principle or ideal of Christian morality. The second will view this ideal in its subjective aspect, that is, as a spiritual influence evolving the various virtues which together constitute the Christian character. The third will treat of this ideal in its objective aspect, that is, as an external standard from which may be deduced the rules of conduct which together form a code of Christian duty. A fourth part will be devoted to Methodology. 


\title{
PART I
}

\section{THE SUPREME IDEAL OF CHRISTIAN LIFE}

\author{
CHAPTER I
}

\section{THE CHRISTIAN IDEAL IN THE ABSTRACT}

IT has been already observed that in the teaching neither of Christ nor of His apostles is there any scientific formulation of the general principle or the particular rules of Christian life. ${ }^{1}$ It would be easy indeed to quote many a familiar phrase from the New Testament which gives admirable expression to various demands of Christian morality; but these are never formulated in language of scientific pretension or as integral parts of a scientific system of Ethics. So far from that, if one were to follow the fashion of culling passages from the Bible without any critical or historical appreciation, it would not be difficult to parade statements of moral obligation which, in appearance at least, are by no means absolutely identical. Not to speak of the apparent conflict between Paul and James in regard to the relation of faith and works, the fundamental principle itself of Christian life assumes a variety of forms even in the teaching of the Master. That principle appears at times to consist in 


\section{SUPREME IDEAL OF CHRISTIAN LIFE}

following Christ. Then it is cmbodied in the formula known as the golden rule, requiring us to do to others whatever we would have them do to us. Again, it is summed up in the command to love God with all our hearts, and our neighbour as ourselves. It takes even the form of the ethical theory known as Perfectionism in the injunction, "Be ye perfect, even as your Father which is in heaven is perfect." ${ }^{1}$ These variations of statement seem, indeed, to find a reconciliation in the teaching of James. He gives the title of "royal law" 2 to the Old Testament injunction to love our neighbour as ourselves, which had apparently been a favourite of the Master. But this description of the law is evidently to be understood as pointing to its practical excellence, rather than to its function as a governing principle in constructing a scientific code of Christian morality. A similar remark may be applied to the same apostle's elevation of the law of liberty by characterising it as "perfect." 3

Still it is no formidable task, by examining and collating the various passages in the New Testament which have a bearing on the subject, to discover a clear unity of thought underlying all variety in the form of statement. Nor has there ever been any real doubt or difference among the leading thinkers of the Christian Church as to the supreme principle of Christian life. The only facts which can conceal this agreement are the unfortunate, though not unnatural, divergence in regard to the application of the principle in particular cases, and the painful discrepancy which often exists between the principle and the practice of Christian Churches as well as of individual Christians.

1 On these variations see Rothe's Thcologische Ethik, vol. i. p. 395.

${ }^{2} \mathrm{~N} \delta \mu \sigma s \beta a \sigma \iota \lambda_{\iota} \delta s$, Jas. ii. 8.

${ }^{3} \mathrm{~T} \in \operatorname{\lambda \epsilon }$ เos, Jas. i. 25 ; cf. ii. 12. 
But the principle itself has always been recognised as that law and inspiration of life which are known most commonly by the name of love. This term ranges over a variety of meanings. But for us it is understood to be a principle of conduct, and a principle to which all rules of Christian living are subservient. Our task, therefore, is to find what is the meaning of love when conceived as such a principle.

At the outset it must be observed that a philosophical principle for moral life cannot be an arbitrary assumption selected from a number of competing alternatives with indifferent claims. Certainly the supreme principle of Christian life rests upon no such capricious foundation. It is rather one of those necessities of rational thought which form the method and ultimate criterion of all science. For it will be generally recognised that, in its essential meaning, love is that principle of action which seeks the good of the person who is its object, as hatred is always conceived to involve evil to the person hated. It is not difficult, therefore, to see what is the origin of love as a practical principle. It is essentially reason or intelligence in its application to the mutual relations of intelligent beings. No being can do evil to another if he is acting under the guidance of reason alone. It is only when he does not clearly understand what he is doing that he can ever do anything but good either to himself or to others. This is evident whenever the nature of good is defined. For the good of every being is essentially what is adapted to his nature. His highest good must be something adapted to give complete satisfaction to the wants which his nature involves. There can never, therefore, be any reason why one being should interfere with the good of another. Such interference must always be unreasonable. For, as we shall see more 


\section{SUPREME IDEAL OF CHRISTIAN LIFE}

fully, no man liveth to himself. There is such complete solidarity in the human family that the good of every individual is inseparably bound up with the good of others. No man, therefore, can deprive another of any real good or inflict any real evil upon another without doing an injury, in general a far more serious injury, to himself. Accordingly the hateful relations of men are significantly described as misunderstandings, and they dissolve into kindly relations as soon as those interested come to understand what it is they are doing.

It follows from this that the Supreme Intelligence cannot without contradiction be conceived as ever doing what is understood by evil to any being in the universe, but must be conceived as willing always what is good. ${ }^{1}$ It is, therefore, no rapturous utterance of a vague mysticism, it is but a sober statement of philosophical truth, that God is Love. Consequently when morality is elevated into the sphere of religion, when goodness becomes godliness, it must take the form of an habitual will to do good; and such a will is what is understood by love as a principle of conduct.

The historical evolution of this principle in the moral life of the world will come under consideration

1 Among the subjects of formal disputation in Scholastic Theology is the question, "Utrum voluntas Dei sit malorum?" The conimon answer seems to have taken the scholastic form, that God eannot will what is evil per se, but only per accidens. That, lowever, is merely another way of saying that $\mathrm{He}$ ean will only what is good, and that $\mathrm{He}$ makes evil, even when willed by others, subservient to the good which He wills. See the Summa Theologica of Thomas Aquinas, Pars 1. Qu. 19, Art. 9. The question continues to be discnssed in later systens, Protestant as well as Catholic, which eling to scholastic eategories and terminology; in general also with the same result. Goethe saw elearly the torture of the evil will that must always at last be bafled in its aim by working out the opposite of what it intends. It is Mephistopheles who describes himself as

" Ein Theil von jener Kraft,

Die stets das Böse will, und stets das Gute schafft." 
at a later stage. But it will be recognised, probably with substantial unanimity, that the principle was never cnunciated with such perspicuity and force as in the teaching of Christ and His apostles. At all events it does form the supreme principle of Christian morality, and our work must be to unfold its implications. But for scientific exactness it is necessary that it should be formulated in some specific statement. Different statements may reasonably be advocated for different purposes. The following is offered merely as a convenient formula for bringing out at once the general spirit of Christian morality and the rules of conduct which that spirit enjoins:

Christian morality consists in loving our fellow-men as we love ourselves, such love being a rational habit of life, which is revealed in Christ as the realisation of God's will with regard to man, and therefore of man's love to God.

This formula calls for a few preliminary explanations to facilitate the deduction of the corollaries which it involves with regard to the characteristic features of Christian life. The necessary explanations may be arranged in four sections, into which the formula is implicitly divided.

\section{§ 1. The equal Love of Neighbour and Self}

The obligation devolving on every man to love his neighbour as himself will be seen to follow directly from the conception of love as the practical application of intelligence to the mutual relations of men. It is important to bear in mind that to scientific intelligence in its clearest and widest view the universe is primarily a community of intelligent beings, and that what is called the matter of the universe can find no scientific 


\section{8

significance except by relation to the intelligences by whom it is interpreted. This conception of the universe can be obscured only through science allowing itself to be dazzled by its own light, and ignoring its own function as the primary factor in the interpretation of material phenomena. But if this view is implied in all real science, it is still more unequivocally demanded by religion and morality. Here men are conceived almost exclusively as intelligent moral beings. But as such no man is independent of his fellows. The individual, as an absolutely isolated being, is a sheer figment of abstract thought, and no more represents any concrete reality than does a centre conceived in abstraction from its circumference. The individual human being is what he is by virtue of his

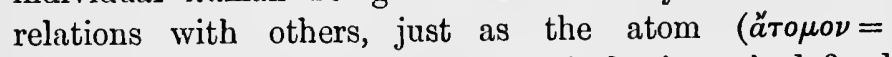
individuum) in physical and chemical science is defined by its reactions with other atoms.

Accordingly every human being, if he would act reasonably, must act with a reasonable regard for the relations in which he stands with his fellow-men. He and they are so utterly and intimately interdependent that none can ignore the good of others without ignoring his own good at the same time. In other words, no man can fail in love to his neighbours without failing thereby in love to himself. It is thus seen to be an elementary truth of practical reason, that a reasonable being ought to seek the good of others as he seeks his own.

This truth offers an explanation of one of the familiar divisions in Ethics which is otherwise apt to be misunderstood. It is common to classify the requirements of moral life in two groups. One comprehends private, personal or individual duties, that is, the duties which a man owes simply to himself without 
necessary reference to any other person. The other comprehends social duties, that is, those which arise from a man's relations to his fellow-men. This classification, however, cannot be interpreted as representing two divisions which are mutually exclusive. It points rather to two different aspects in which all virtue may be viewed. It is admitted, indeed, that there are some virtues which do not involve any necessary reference beyond the individual by whom they are cultivated. Such is temperance. A man thrown on an uninhabited island would still be under an obligation to be temperate in the indulgence of his appetites. But it may with good ground be maintained that in such a case he would merely carry over into his solitary life the moral ideas and habits which had been developed by his previous social relations, and it may fairly be questioned whether a life of absolute solitude would ever develop any virtue whatever, personal or social. But it is truly futile to discuss what a human being might become if he were brought up in complete isolation from his fellows. Such a being would not, in fact, be human at all in the proper sense of the term. Every human being, as we have seen, becomes what he is by reaction with his environment in society as well as in nature. The whole moral life of man is a result of that reaction. But the resultant moral life implies not merely a relation to society. That very relation requires the development in the individual himself of certain habits constituting his moral character. As these habits result from the training of his own nature, they may be spoken of as his personal virtues or vices; but as they are trained by his conduct in relation to others, they may with equal propriety be described as social. In reality, therefore, virtue is neither exclusively social 
nor exclusively personal. It is personal in one aspect, social in another.

These two aspects of virtue, however, appear at least to come into conflict at times, and in such conflict one or the other commonly gains the upper hand. The predominance of the one has come to be technically described as Egoism, that of the other as Altruism. ${ }^{1}$ In practical life the former is commonly characterised as selfishness, the latter as unselfishness or disinterestedness. The terms Egoism and Altruism are properly employed to denote scientific theories in Ethics and Psychology, which are apt to be uncritically appreciated when, as in the language of older writers, one is stigmatised as selfish while the other is commended as unselfish. As purely technical terms, Egoism and Altruism avoid the suggestion of any such prejudice. Egoism is thus taken to mean in Ethics the doctrine that all virtue finds its logical foundation, its rational vindication, in being the indispensable condition of the virtuous agent's own good. In Psychology it designates the theory that all the primitive impulses of human action are but varied forms of the desire for personal pleasure or of the revulsion from personal pain; and that all other motives, however disinterested in appearance, are in reality only outgrowths of these primitive impulses. On the other hand, Altruism, as a scientific term, denotes any theory which is opposed to Egoism in Ethics or Psychology.

It will thus be seen that the rival claims of self and others create at times a certain perplexity in theory as well as practice. On its practical side this problem may continue long to perplex the moral judgment. The tangled web of human life makes it frequently

${ }^{1}$ Henry Drummond has ventured on the coinage, Selfism and Otherism. Ascent of Man, p. 281. 
difficult to unravel the right line of conduct. But for the scientific thinker this cannot imply that there is no right line; that there may be two claims, both rightful, yet irreconcilable with one another. This inference, indeed, has been accepted by some thinkers. Sir Leslie Stephen, for example, considers the reconciliation of disinterested virtue with personal happiness to be as hopeless as the attempt to square the circle or to discover perpetual motion. ${ }^{1}$ But this would reduce moral life from an intelligible order to an unintelligible chaos, and thus render any science of it impossible. And the inference rests on an inadequate definition of what constitutes love as the supreme principle of moral life. In this sense, as we have seen, love is the will to do good; but the will to do any real good to another can never come into irreconcilable conflict with the will to do real good to oneself. Such a conflict between r self and others is averted by avoiding any unreasonable assertion of the claims of either. The individual is to love his neighbour as himself-not less, but also not more, than he loves himself. $\mathrm{He}$ is to treat himself simply as one of the citizens in the kingdom of God, endowed, so far as the interests of that kingdom are concerned, with the same rights-neither more nor less than the same rights-which are accorded to every other citizen.

Here we find the true significance of that trinity of social ideals in which the democratic aspirations of the modern world have often found expression, Liberty, Equality, Fraternity. The order of ethical thought in which these are evolved is obviously the reverse of their common statement. The former is the order of Christian thought. Through the spirit of Christ all the national and social distinctions which separate men

${ }^{1}$ See The Sciencc of Ethics, by Leslie Stephen, p. 430. 


\section{SUPREME IDEAL OF CHRISTIAN LIFE}

from one another are broken down, ${ }^{1}$ so that all families and tribes of men find their common Father in God. ${ }^{2}$ All men are thus put on a footing of equality through their spiritual brotherhood as the common children of one Eternal Father. And this equality can have no meaning except as an equal right for all; nor can there be an equal right for all, which does not allow every individual liberty to act as he pleases. But evcry individual can enjoy this freedom in reality only when each is restricted from interfering with the freedom of the rest.

\section{$\S$ 2. Christian Love as a Rational Habit}

It has been already observed that the word love has considerable fluidity of meaning. But there are two dominant meanings under which most applications of the term may be ranged. This distinction in regard to love represents a general differentiation which runs through the whole of our emotional life. The distinction was brought into prominence among English moralists and psychologists by Bishop Butler in his treatment of the emotion of anger; ${ }^{3}$ but it is equally applicable to all our emotions, and represents, in fact, the common order of their evolution. For all emotion is primarily excited by purely natural stimulants, and tends, therefore, to take the type of a purely animal instinct. But gradually with the evolution of mind reason asserts its sway more and more, so that emotional excitement takes on a new character from a rcasonable regard for its object. It is thus that all emotion tends to assume two types, the earlicr of which may be described as instinctive, natural or animal, while the later is dis-

${ }^{1}$ Gal. iii. 28 ; Eph. iii. 6.

2 Eph. iii. 15.

${ }^{3}$ See his Scrmon on Resentment. 
tinctively rational or intelligent. The instinctive forms of emotion represent merely the peculiar temperament or disposition with which a man is endowed by nature; they do not constitute his moral character in the strict sense of the term. It need scarcely be explained, therefore, though it is infinitely important to bear in mind, that the supreme principle of Christian morality is not the instinctive affection known by the name of love. That kind of affection depends on natural stimulants, and is not summoned at will, so that it cannot be marle the subject of a moral command. A man may have the good fortune to be endowed by nature with a loving disposition. Such love, however, is merely good nature in the proper use of the term. It is, then, the nature, not the will, of a man that is good; and it is good will, strictly understood, rather than good nature, that morality enjoins. But will is essentially an intelligent impulse to action. Intelligent direction is the feature which distinguishes it from a blind instinct, from an unreflecting natural impulse.

But if Christian love is to be distinguished from impulses of an instinctive nature, it must also be distinguished from another class of impulses. For as the supreme principle of Christian morality, love is not only rational, it must also be habitual. Now habit is, like instinct, a certain readiness in action. But there are many forms of readiness that are neither instinctive nor habitual. Habit and instinct are both permanent tendencies of action. But men are sometimes only too ready to act under any transient impulse like the momentary excitement of a sudden passion. Such an impulse, however, does not necessarily indicate any feature of a man's real character. Consequently, though an action done under such an impulse may be beneficial to the agent or others, he is not entitled to the same 


\section{SUPREME IDEAL OF CHRISTIAN LIFE}

credit as if it represented an habitual tendency of his life. On the other hand, if the action be baneful, however deeply it may be deplored, it is not treated with the same disapproval as if it represented the confirmed character of the agent.

"The sin that practice burns into the blood, And not the one dark hour that brings remorse, Shall brand us after of whose fold we be."1

Love, therefore, if it is to be a moral principle of conduct, must not only, unlike instinct, be rational, but, like instinct, be permanent. That is what is meant by speaking of it as habitual.

Habit, then, as well as instinct, is a permanent readiness in action, the difference being that, while the latter is inborn as a part of our constitution, the former is acquired by practice. The relation of the two will form the subject of future inquiry. But meanwhile it may be observed that instinct itself depends on practice for its continuance and force. An instinct often dies out from want of practice or from the counteraction of some incompatible habit. Accordingly every man is what he is by virtue of the habits which he forms. In popular language he is often described as a creature of habit, a slave of custom. It is an often quoted phrase of Paley's, that " man is a bundle of habits." 2

The supreme principle of Christian morality is thus $>$ to be interpreted as meaning an habitual will to do good to others equally with ourselves. This it is that constitutes Christian character, for it has been recognised that character is truly described by Novalis as a completely formed will. ${ }^{3}$

1 Tennyson's "Merlin and Vivien."

2 See his Mforal and Political Philosophy, bk. i. ch. vii.

3 "Der Character ist ein vollkommen gebildeter Wille" (Novalis, 
§3. The Chrristian Ideal Revealed in Cirrist as the Realisation of God's Will witi regard to Man

On the subject of this section it is not necessary to enlarge. It is involved in the most meagre conception of Christianity held by any Christian sect. Only by refusing to think of himself as Christian in any sense of the term can a man cease to consider Christ as in a very real scnse an embodiment or incarnation of God's will with regard to man.

This truth is apt to be obscured by the perplexing controversies which have disturbed the Christian world regarding the nature of Christ. In the primitive Church, more prominently than at any other later period, it was personal devotion to Him that formed the distinctive bond of union among His disciples. It was therefore natural, and it is significant, that in early Christian speculation Christology became by far the most prominent part of theological inquiry. With the extension of the Church into the pagan world, it was inevitable that speculation on this subject eame to be directed mainly by categories of Greek thought which were almost exclusively metaphysical. They were such

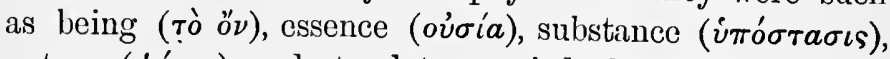
nature ( $\phi \dot{v} \sigma \iota s)$, and at a later period the idea expressed by $\pi \rho o ́ \sigma \omega \pi o \nu$, which was rendered into Latin by persona.

With thesc metaphysical concepts and their application in Christology, we have nothing to do here. For

Schriften, Bd. i. S. 242, 5te Aufl.). Professor James quotes this with approval in the chapter on liabit in his Principles of Psychology, vol. $\mathbf{i}$. 1). 125, and in his Bricfer Coursc, p. 147. Unfortunately in both places he credits the saying to Mr. J. S. Mill ; but Mill (System of Logic, bk. vi. ch. ii.) quotes it explicitly from Novalis. He, too, gives it his approval. Probably he got it from Carlyle's Essay on Novalis, where also it is quoted. 


\section{SUPREME IDEAL OF CHRISTIAN LIFE}

us the relation of Christ to God is conceived only in its ethical aspect, and for ethical purposes His union with God is the union of His will with God's will. ${ }^{1}$ It is by this union that He becomes the revealer of God's will to man. It is not necessary to inquire whether or how far He reveals non-ethical attributes of the divine nature. For us it is sufficient that $\mathrm{He}$ does reveal the will of God concerning ourselves, that He reveals what God wills us to be, and what we may become if we do not thwart that will. And if $\mathrm{He}$ Himself declares that any man who has seen Him may be said to have seen the Father also, ${ }^{2}$ we may perhaps find the most momentous significance of the declaration in another saying of His: "Blessed are the pure in heart: for they shall see God." 3

It is for this reason also that, as already pointed out, moralists like Mr. Mill, who do not consider themselves Christians, recognise frankly the value of Christ's example for the moral guidance and inspiration of humanity.

§ 4. The Christian Ideal as the Realisation of MaN's Love TO GOD

This aspect of the supreme principle of Christian life follows of necessity from the previous. All real union of the finite moral personality with his Infinite Father is an ethical union, an union of will. But the will of God, as we have seen, is good will, or love in the highest sense of the term; and that is the will to do good to

I It is worth while to connect the declaration of John x. 30, "I and the Father are one," with the explanatory remarks that follow in vv. 37, 38 : "If I do not the works of My Father, believe Me not. But if I do them, though ye believe not $\mathrm{Me}$, believe the works: that ye may know and understand that the Father is in $\mathrm{Me}$, and I in the Father." Compare John v. 30, xiv. 10-11.

2 John xiv. 9.

3 Matt. v. 8. 
every being. Consequently there can be no union of man with God, such as the love of God implies, except by perfect harmony with the will of God in willing the $r$ good of all.

By this it is not to be assumed that man's love of God is a mere figure of speech to describe the love of man for his fellows. It may be maintained, and will in fact be maintained, at a later stage, that the love of God is no vague aspiration after a mere ideal of man's creation, but a veritable communion of the finite spirit with the Infinite Spirit of the universe. But after making all allowance for this claim of religious consciousness, it remains a fact that there can be no veritable communion of man with God which does not involve a reconciliation of the human will with the divine will to do good to all creatures. Therefore the love of man for his neighbour as for himself is the realisation of his love to God.

This is the unequivocal teaching of all the sources from which Christian faith is drawn. Even in the Old Testament the keeping of His commandments, the doing of His will, is associated with all genuine love of God. This is peculiarly clear in the spiritual interpretation of the law given by Deuteronomy. ${ }^{1}$ It stands out prominently also in the general teaching of the prophets. But, like all the other peculiarly spiritual teachings of the Old Testament, this becomes far more definitely pronounced in the New. By Christ Himself the doing of $\mathrm{His}$ will is made the one test of love or reverence for Him. "If ye love Me, keep My commandments." 2 Here, certainly, the first three Gospels are in harmony with the fourth. "Not every one that saith unto Me, Lord, Lord, shall enter into the kingdom of heaven;

${ }^{1}$ See, e.g., Deut. vi. 4-9, x. 12, 13, xi. 13, xxx. 16, 20.

2 John xiv. 15, 21, 23, 24. 


\section{SUPREME IDEAL OF CHRISTIAN LIFE}

but he that doeth the will of My Father which is in heaven." 1 Here also the teaching of the apostles reflects unambiguously that of the Master. It finds an expression that is peeuliarly significant, as coming from the apostle who represents most prominently that mystical quietism which has too often wasted moral energy in the indulgence of a purely contemplative, inactive love of God. "This is the love of God," says St. John, "that we keep His commandments." ${ }^{2}$ And there is an unwonted intensity of indignation in the language of the same apostle when he scouts the idea of separating the love of God from the love of men. "If a man say, I love God, while be hateth his brother, he is a liar: for he that loveth not his brother whom he hath seen, how can he love God whom he hath not seen ?" 3

1 Matt. vii. 21 ; cf. xii. 50.

21 John v. 3 ; ef. iv. 21.

${ }^{3} 1$ John iv. 20. 


\section{CHAPTER II}

\section{EVOLUTION OF THE CIRISTIAN IDEAL}

THE evolution of moral life all through the history of man indicates a gradual expansion of the moral ideal; and it is of infinite interest and significance to the student of Christian Ethics, that this evolution has been all along a movement towards a principle of morality substantially identical with that explained in the previous chapter. This will perhaps be indicated more clearly by tracing, first of all, the general trend of thought in the expansion of the moral ideal, and then tracing that expansion in the evolution of moral intelligence among the two people from whom almost exclusively Christianity has drawn its moral system.

Before entering on this sketch, it is desirable to refer to a question which may perhaps cause perplexity to some minds. It is not uncommon to conceive of Christianity as a system of religious and ethical thought once for all revealed to man in complete form. This conception disconnects it from the general evolution of intellectual and moral and religious life in the world. Those who are guided by this conception are apt to look askance at any attempt to find in the moral and religious ideas of Christianity a culmination of movements which can be traced all through the providential evolution of human life from the beginning. They shrink from the admission that any of the truths of Christianity could 


\section{SUPREME IDEAL OF CHRISTIAN LIFE}

have been to any extent anticipated. Faith in these truths appears to be undermined if they are proved to be not absolutely original.

Yet to the scientific thinker absolute originality is so far from being any recommendation of a doctrine that it would be viewed rather as a ground of suspicion, and the claim of such originality becomes one of the little vanities of intellectual work. For the earnest purposes of life the question with regard to any teaching is not whether it is original, but whether it is true. However novel or important it may appear, the extent of its originality is a wholly subordinate issue, a matter merely of historical curiosity. Accordingly in early Christian literature one fails to meet with any obtrusive assertion of originality. On the other hand, from St. Paul down through the early Apologists and Greek Fathers there is a remarkable persistence in asserting the identity of Christian truth with the best teaching of the preChristian world in regard to morality and religion. And that remains the most unassailable proof of the divine origin of the Christian system of thought, that it had been able to absorb into itself the finest thought of all the ages.

\section{$\S 1$. General Tendency in tile Expansion of the Moral IDEaL}

The expansion of the moral ideal is one phase of the evolution of intelligence in general. For intelligence does not work in the moral sphere along lines different from those which it follows in other spheres of its activity. Now there is nothing more evident to common experience as well as to psychological observation, than the fact that in childhood intelligence plays within a very narrow range, while every new stage in its growth 


\section{EVOLUTION OF 'THE CHRISTIAN IDEAL}

is attained by an exertion of wider sweep. This movement obviously can find no permanent halting-place till it reaches a point of view that is universal. The general movement thus described is seen with peculiar clearness in the evolution of moral intelligence. Here the movement runs along two lines. The ideal at which it aims throughout its progress is broadened in extent while it is deepened in intent.

1. The broadening extent of the moral ideal has long been observed to be a prominent feature of human history. Research into the primitive conditions of society soon discloses the fact that in general moral obligation is not at first separated from the instinctive affections which grow out of the relations of kindred. Accordingly the earliest organisation of society seems to be everywhere founded on these relations. ${ }^{1}$ The family is the common type on which society is constructed at first. When social growth expands beyond the limits of family relationship into wider unions, such as are described as clans or tribes, these do not by any means break away from their original type. They seem to become possible only by extending to the clan or tribe the moral relations of family life, that is, by conceiving clansmen or tribesmen as the children of a common patriarch, the descendants of a common ancestor; and the social sentiment of young communities finds a basis for itself in an ideal history by the fiction of a glorified eponymous hero, or even of a grotesque ancestral totem. So completely do natural relations take the place of moral relations among primitive men,

${ }^{1}$ It is not desirable nor is it necessary here to meddle with controverted theories on the evolution of primitive society. There is no intention, therefore, of excluding sympathy with G. Tarde's protest against the common assumption of a rigid uniformity in the course of social evolution among all primitive races. See his Transformations des Droits (1900), pp. 10, 11. 


\section{SUPREME IDEAL OF CHRISTIAN LIFE}

that in many cases at least there appears to be no proper differentiation between family and clan and tribe. But it is evident that this cannot last. By the mere growth of population a time must come when it is no longer possible to think of all the members of a community being in any obvious way related to one another by blood. Then a new bond of union is required. Such a bond is found in national life. Men realise an obligation to one another as citizens of one fatherland, nembers of one political organisation, without thought of any kinship. But the same tendency, which brings this stage of social development, must force a further expansion. The partition-walls of nationality itself, as well as of other divisions among men, must be borne down before the advance of moral intelligence. Human beings must at last become conscious of a moral relation with one another on the simple ground of their common humanity, without regard to any of the distinctions, whether natural or conventional, by which they happen to be separated. The world is still indeed, but slowly, developing the moral habits and customs which are necessary to give effect to this ideal; but it has fortunately found a place long ago among the common thoughts of the civilised races, and forms a familiar theme in their literature. Nothing can show how completely the theme has become a commonplace of ethical reflection, than to find it dressed in the well-trimmed couplets of Pope:

"God moves from Whole to Parts; But liuman soul Must rise from Individual to Whole.

Self-Iove but serves the virtuous mind to wake,

$\Lambda \mathrm{s}$ the small pebble stirs the peaceful lake:

The centre moved, a circle straight sueceeds, Anotleer still, and still another spreasls, Friend, parent, neighbour first it will embrace; His country next; and next all humau race; 
Wide and more wide th' o'erflowings of the mind Take every creature in of every kind ;

Earth smiles around with boundless bounty blest, And heaven beholds its image in his breast." 1

2. Of different, but equally momentous, import has been the evolution of the moral ideal in its intent. It is a familiar fact that moral obligation at first attaches more or less exclusively to the external act required, and it is an unhappy result of this restriction that the real intent of an obligation may be ignored. In its lowest phase the restriction is apt to interpret the obligations of social morality by the requirements of custom or of written law, and surprise may be aroused by any demand which neither law nor custom can be cited to enforce. "It is not in the bond" forms for many minds an adequate reason for refusing to recognise the obligation of a claim.

Even among primitive men, indeed, there are glimmerings of an ideal nobler than any embodied in common usage or in written statute, for God has never left His children without a witness for Himself. In more advanced societies also the common moral consciousness of the world gives expression to this nobler ideal in many a proverbial phrase, such as the familiar significant description of a man of peculiarly honourable character as one whose "word is as good as his bond." But among the great mass of men the aspiration towards a purer ideal of their social relations is fettered by the conception of law confounding that of morality proper. The obligations of social morality are still apt to be interpreted after the type of legal obligations; they are limited to those duties which must be conceded to a very niggardly interpretation of what bare justice requires. Consequently the great moral and religious teachers in

${ }^{1}$ Essay on Man, iv. 361-372. 


\section{SUPREME IDEAI, OF CHRIS'IIAN LIFE}

all ages have seen clearly that the claims of social morality must raise the moral ideal to a loftier conception of justice than that which is embodied in law or in prevalent opinion, if indeed the conception of strict justice must not be left altogether behind.

For the concept of strict justice, like all narrow concepts, is inadequate to explain fully the sphere of thought to which it applies. This arises from the very determinateness which is its characteristic feature, its characteristic excellence for the purposes of civic life. For in order to maintain just relations between man and man in social intercourse, it is obviously essential that the actions which they may exact from one another should be defined with the most rigid accuracy possible. But to be definite is to be finite or limited; and a limited concept, especially in the manifold complications of social life, is apt to exclude data which may be absolutely essential to complete knowledge, and therefore to just judgment. Accordingly it is a very old experience that justice, when narrowly defined and rigidly enforced, may be very far from justice in the full sense of the term. "Summum jus, summa injuria," is quoted by Cicero as a well-worn proverb in his time. ${ }^{1}$ For the same reason it is often possible that the claims of justice, when defined from one point of view, may come into conflict with claims defined from another; and this is evidently the source of that uncertainty with regard to the issue of legal procedure, which has become almost a byword in civilised communities. This is also the reason why the moral consciousness is forcel to recognise the inadequacy of a morality confined within the

1 "Jam tritum sermone proverbium" (De Off. i. 10). A century earlier the proverb is used in the Heautontimoroumcnos of Terence (Aet iv. Sc. 5), and the Latin dramatist seems merely to translate his Greek original, for the same sentiment is met with anong the fragments of Menander. 
restrictions of bare justice. But this very inadequacy points to a morality of wider range, which embraces justice itself by emancipating it from the bondage of narrow rules into the freedom of spiritual life.

It has therefore been customary even from ancient times to distinguish the higher phase of social morality by some such designation as benevolence or love. The distinction need not be considered absolute. The two phases of morality may be divided by no hard and fast line of demarcation. It may well be that love is merely the highest evolution of justice, justice merely $v$ an undeveloped love. For us it is sufficient that the highest moral teaching, pagan as well as Christian, ancient as well as modern, recognises the moral enthusiasm which we understand by love as an all-comprehensive inspiration of conduct, absorbing the limited requirements of what is ordinarily understood by justice. Certainly it is one essential part of the glad tidings which Christianity carries to the world, that the Kingdom of God, which it invites men to enter, is a social condition in which they shall not, in their intercourse with one another, be limited by any stingy calculation of what rigid justice may enforce, but shall lovingly place themselves and all their possessions at the service of one another.

The obligations of justice are, in scientific language, often distinguished as determinate from the indeterminate obligations of love. This expression of the distinction helps us to understand the nature of the restrictions by which social morality is limited at the earlier stage of mere justice, and the nature of the freedom which the moral spirit attains on expanding to the larger enthusiasms of love. To make this clear, it is necessary to explain that, wherever a determinate obligation exists, there must be not only the obligation on one side, but 


\section{SUPREME IDEAL OF CHRISTIAN LIFE}

a corresponding right on the other side to demand the fulfilment of the obligation. Right and obligation become thus strictly correlative. Now in justice-in fairness or honesty to both parties-the obligation and the right must be defined with the utmost possible exactness. But to define these is to limit, to narrow down, the meaning of the terms in which they are stated, so as to leave no room for misapprehension about what one may claim, what the other is bound to do. In bare justice, therefore, one may rigorously exact and enforce the fulfilment of his rightful claims, but the other is not bound to yield more than precisely what is required by the determinate obligation. Accordingly, if there be no higher and freer principle of conduct than bare justice, a man may be rigidly, cruelly exacting in the interpretation and enforcement of his rights, while he may be correspondingly stingy in the interpretation and performance of his obligations. Now the evolution of social morality to the standpoint of love emancipates from this narrowness in the interpretation both of obligations and of rights. It enlarges the sentiment of obligation by making it more exacting, while it frees from self-assertive exaction the sentiment of right. As sometimes expressed, the idea of right falls into the background, while the idea of duty comes to the front as the leading motive of life. Note the effect upon both ideas.

(1) As long as moral consciousness lags at the stage of bare justice, man is apt to take to himself the satisfaction of having fulfilled all his obligations if he merely refrains from injuring others. In other words, the obligations of social life become purely negative. Abstinence from wrong is their sole aim ; "Thou shalt not," their formula. Even when justice as in a contract imposes the performance of an action, the essence of the obligation is simply 
to refrain from injuring the other party by failure to perform the action enjoined. It does not require the contractor to do anything beyond what is definitely prescribed in his bond. On the other hand, the obligations of love are in their essence positive. Their language is, "Ye shall do to others whatsoever ye would that they should do to you"; "Thou shalt love thy neighbour as thyself." It is impossible to overestimate the revolution implied in the passage from the negative to the positive pole of morality. The whole attitude of the mind to the practical problems of life is thereby reversed. Instead of waiting with more or less grudging reluctance till some rigid requirement of justice can be enforced, the liberated spirit now runs out in eager quest of opportunities for doing good to fellow-men. This it is that constitutes Christian conversion in its social effect; and any conversion, which does not bring with it this inspiration of life by love, can profit a man nothing.

(2) But in this conversion the sentiment of right undergoes a transformation similar to that of the sentiment of obligation. The morality of bare justice interprets a right in the full measure of the claims it involves. The contractor is considered at liberty in justice to exact everything that is implied in his bond, and in general all men are regarded as entitled to all the gain which their superior advantages enable them to wring from their fellow-men. The necessity of others becomes their opportunity, and justice in itself is supposed to raise no obstacle against driving and enforcing the hardest bargain with those in need. Love, on the other hand, emancipates social morality from this spirit of rigorous exaction, and forces men to a totally different attitude in the moral interpretation of the necessities of others as well as of their own advantages. If a man 


\section{SUPREME IDEAL OF CHRISTIAN LIFE}

possesses any kind of superiority,-if he is endowed by nature with superior strength or skill, if he is born or rises into a higher social rank, if he inherits or amasses great wealth, if he is gifted with a superior intellect, a refined taste, a resolute will,- then such pre-eminence is not to be conceived as a vantage-ground from which he may legitimately grasp all the benefits which it enables him to extort from his fellows. On the contrary, the claims founded on his superiority will, in the light of the higher morality of love, be more modestly estimated, will be less stringently exacted, will in many cases be generously relinquished altogether. The higher morality, in fact, will interpret a man's superiority, not so much as giving him a right to command the services of others, but rather as imposing on him a more imperative obligation to labour in the service of his less fortunate fellow-creatures.

It is, therefore, by a necessary dialectic that social morality rises from the narrow restrictions of justice to the larger range of benevolence, and it is thus only in accordance with what might be expected to find anticipations of this evolution in pre-Christian moral teaching. Such anticipations are of peculiar interest for us in the regions of Greek and Hebrew thought, inasmuch as we derive from them all that is of real value in our spiritual civilisation.

\section{$\S$ 2. Evolution of the Moral Idfal among tie Hebrews}

Our inquiry does not call us to enter on the large problem of the gencral relation between Judaism and Christianity. We have simply to recognise what is one of the most patent truisms of history, that Judaism formed the primary soil out of which Christianity grew. 


\section{EVOLU'TION OF 'THE CHRISTIAN IDEAL}

Even that fact is here viewed merely in one aspect, in its bearing on the Ethics of Christianity. ${ }^{1}$ This aspect has been prominent in Cliristian thought from the beginning. In the New Testament, indeed, it seems as if it were too prominently obtruded for the wants of modern Christendom, however natural and inevitable that prominence may have been at the time. But historical truth compels us to accept the New Testament view of the Jews as the people "of whom is Christ as concerning the flesh," 2 and therefore to interpret Christianity as growing out of Judaism in accordance with the laws that rule through the providential government of the world. Consequently that body of moral and religious doctrine which the Jews comprehended under the designation of "the Law" formed for them a

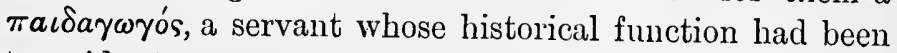
to guide them to the school of Christ. ${ }^{3}$

1 The historians of Christian Ethics in general naturally touch upon this point. Ziegler (Gesehiehte der Christliehen Ethik, 2te Ausg. 1892), gives it a lengthy chapter, treating it from the standpoint of critical scholarship, with a sonewhat depreciatory estimate of the contribution of Judaism to Christian Ethics. Gass (Geschichte der Christliehen Ethik, 1881) is disappointingly meagre in comparison, giving mercly a bricf seetion in his chapter on Biblical Ethics. Wuttke and Luthardt, whose histories have bcen translated into English, both deal with Jewish Ethics at considerable length from a rigidly Lutheran point of vicw. The reader of either will probably sympathise with the translator of Luthardt (in his preface, p. xviii, note) in "desiderating a broader standpoint than the strict Lutheranism that determines most of the historical estimates." There is an English monograph on the situject, The Ethies of the Old Testament, by the Rev. W. S. Bruce (T. \& T. Clark, Edinburgl, 1895), written in a reverently conservative spirit, though not without recognition of the claims of modern criticisn.

${ }^{2}$ Rom. ix. 5 ; cf. i. 3 ; Acts ii. 30.

${ }^{3}$ Gal. iii. 24. Perhajs it is not umecessary to explain that the $\pi a \iota \delta a \gamma \omega \gamma$ ós was not a pædagogue in our sense of the term, as the English Authorised Version would lead one to suppose. By ancient writers he

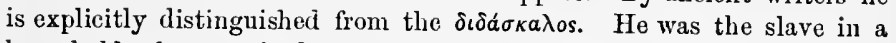
household who exercised a general superintendence over the education 
In estimating the ethical code of Judaism with this special end in view, we are to a large extent relieved from the necessity of entering on the problems which have been raised by modern Biblical Criticism. It need scarcely be said that the attitude of Christ and His apostles, as well as of early Christians in general, towards the Old Testament, is in no sense that of the scientific critic. 'To them the Old Testament was simply a body of writings invested with such reverence and authority as led them naturally and justifiably to appeal to it in confirmation of Christian teaching. There are, indeed, certain facts obtruded in the Old Testament itself which must be accepted under any critical theory. It is evident, for example, that "the Law" did not at any time represent, except by inference from its provisions, the actual condition of the Jewish people. On the contrary, these provisions themselves point to a moral condition calling for the most drastic measures, for a penal code of Draconic severity, in order to prevent the utter dissolution of society, while the narrative and prophetic parts of the Old Testament imply that the corruption of the great body of the people at times must have driven legislator and prophet alike to despair. Moreover, it may be that "the Law" itself represents no legislation ever actually enacted by any governmental authority backed with the requisite power of enforcement. The jural organisation of society which it describes may have been, from first to last, as purely ideal as the Republic of Plato or any other Utopia. All legal codes, in fact, are, in a sense, ideals. Their penal enactments of the boys, rarely of the daughters, especially conducting them to and from school or gymnasium. It is obviously this special function that is referred to in the verse here cited from the Epistle to the Galatians; but in the verse immediately following, as well as in 1 Cor. iv. 15, the allusion is rather to the general tutorial authority of the $\pi a i \delta a \gamma \omega \gamma \delta s$. See Smith's Dict. of Antiq. under the word. 
imply that they are not, and are not expected to be, obeyed by all their subjects. But that does not alter the fact, it rather implies, that Jewish law, like all real or imaginary legislation, does represent a certain ideal of life; and our task now is to examine this ideal in its relation to the ideal of Christianity.

1. At the outset we are met by the conspicuous fact that the moral ideal of Judaism, like that of Christendom, is essentially religious. At a later period, indeed, the period represented by Ecclesiastes and Proverbs among canonical books, in apocryphal literature by The Wisdom of Solomon and The Wisdom of Jesus the Son of Sirach, moral reflection had begun to separate in some measure, though only in some measure, from religious thought. But it may fairly be doubted whether these works represent an intrinsic development of the Hebrew mind, and not rather the change which was coming over it from the influence of Greece. In any case, these are portions of Hebrew literature of which there is very little trace in early Christian thought; and the influence of the Hebrew ideal upon Christianity all went to make morality essentially bound up with religion. Moral obligations were conceived in the Hebrew mind to be divine commands, the moral law in general became a revelation of the Will that rules the universe. This becomes all the more obvious and significant when the distinctive characteristics of Hebrew religion are considered.

(1) In the first place, then, that religion was monotheistic. In asserting or explaining this aspect of Judaism we need not become entangled in the problems which have been raised in regard to its historical development. It may be that Jehovah was at first merely a tribal god, the divine protector of a Semitic tribe, who was not conceived as excluding other gods from being co-ordinate protectors of other tribes. But 


\section{SUPREME IDEAL OF CHRISTIAN LIFE}

even if there be unmistakable traees of sueh a primitive stage in the evolution of Hebrew religion, it must have vanished eompletely for generations before the rise of Christianity. To the eontemporaries of Christ the Old Testament was unquestionably an exponent of monotheism in the proper sense of the term. The eonseiousness of this fact explains in a large measure the peculiar attitude of the Jews towards other races. That attitude, as we shall presently see, had some objectionable features; but it was not without a pleasing side as well. It took a remarkable form in the contact with Greek civilisation brought about by the Maeedonian enquests, and the consequent deportation and migration of Jews to Alexandria. The result of this eontact on the part of the Jews formed a striking eontrast with the result of the same eontact at a later period on the part of the Romans. With a singular absenee of their ordinary national pride the Romans acknowledged that in the higher regions of intelleetual life they had to own complete subjugation by the people over whom they had won an easy military triumph. No such humiliation was that of the Hellenistie Jews who, in the second and even in the third eentury B.C., were eoming into extensive intercourse with Greeks, and learning to appreciate their literature. These Jews felt that they eould face the splendid eulture of Hellas without the necessity of bowing before it in humble subjection. Their literature, too, had a mission in the higher civilisation of the world. Through it and the life it represented they enjoyed, as a eommon heritage of their people, familiarity with the eentral thought of all true religion. On the other hand, to that great thought only the highest minds of Greee had been able to elear their way through the bewilderment of a popular polytheism, and in the expression of it they eontinued to be provokingly hampered by the 


\section{EVOLUTION OF THF CHRISTIAN IDEAI.}

disconcerting ideas and language of a polytheistic race. 'This distinctive feature of Jewish religion excited a deeply interested curiosity in the higher minds of the Gentile world to whom it became known. Of these Tacitus may be taken as a fair representative. With all the haughty sentiment of a Roman patrician toward an Oriental barbarian race, and with a good deal of unfairness arising from amusingly inadequate information, he yet rises to a certain dignity of language in describing the peculiar religion of the despised people. Contrasting it specially with the grotesque zoolatry of the neighbouring Egypt, he described the Jews as worshipping but one Supreme Deity, and worshipping Him with the mind alone, as they deemed it impious to represent in human likeness and in perishable materials the Being who is supremely elevated above all the changeable forms of the material world. ${ }^{1}$

(2) But the spiritual monotheism of the Jews, which called forth the admiration of the Roman historian, involved another characteristic. For if the moral ideal of the Jews was essentially religious, it is quite as true that their religious ideal was essentially moral. In this respect it formed a marked contrast with the paganism of the Greeo-Roman world, in which it had already obtained a footing at many points before the advent of Christ. The pagan religions were, in prominent features at least, rather religions of nature (Naturreligionen) than religions of morality. Many, indeed, at least of the later ereations of Greco-Roman religion, were personifications of moral attributes, but its deities are often merely personifications of forces of nature in complete abstrac-

1 “"Egyptii pleraque animalia effigiesque compositas venerantur; Judxei mente sola umnmque numen intelligunt. Profanos qui Deum imagines mortalibus materiis in speeies hominum effingant; summum illud et aternum, neque mutabile neque interiturum. Igitur nulla simulacra urbibus suis, nedum templis, sinunt" (Histor. v. 5). 


\section{SUPREME IDEAL OF CHRISTIAN LIFE}

tion from any significance for moral life. Accordingly, to cultured reflection, even in pagan minds, these deities excited at times a shock of scornful indignation or satire in the vein of a Hebrew prophet. But the Supreme Being of Hebrew worship, separated, as Tacitus pointed out, from all confusing association with material figures, conceived only in the mind, became naturally the ideal of moral life, and of moral life in its spiritual essence. "Be ye holy, for I am holy," ${ }^{1}$ became a formula for ethical as well as religious thought.

It is not, of course, to be understood that this was an unique message to the Hebrew race. All races of men are called to obey this command. Moreover, all races have recognised the call in some measure, in so far as they have recognised, even in the most rudimentary fashion, the obligations of national and individual morality. Some even may plausibly claim that they have implicitly obeyed the command in fuller measure than the Jews, by rising to a higher morality than the great mass of the Jewish people seem at any time to have reached. But no other nation has ever explicitly recognised as the very purpose of its existence the mission which was uninterruptedly thundered into the ears of the Jewish people by the voices of its inspired teachers.

2. It is this ideal that we are now to examine in its historical significance as a stage in the evolution of the Christian ideal. That significance is one of profound interest. For, notwithstanding any drawbacks that must be discounted in the exposition of the Jewish ideal or in its application throughout Jewish history, it embodies a moral spirit sufficiently humanitarian to

1 The idea of this formula is the dominant note of the whole Old Testament. The formula itself recurs repeatedly with slight variations. In the New Testament it is quoted as if it were a faniliar saying (1 Pet. i. 16), and it sounds like a fine echo of it that we hear in "Be ye perfect, even as your Father which is in heaven is perfect" (Matt. v. 48). 
justify the attitude of Christ and His apostles in maintaining that their teaching was not an abrogation of "the Law," was rather its true fulfilment. This will be cvident whether the ideal is viewed in its extensive or its intensive significance.

(1) In its extent the meaning of the Jewish ideal is intrinsically bound up with the fact of its being a divine command. As such it came to the Jew as a command from the Being who is supreme authority over all races of men. Now there is one form of divine command which is of peculiar import in this connection, because it seems to have been a favourite formula of Jewish law itself, and was adopted with pronounced approval by Christ as expressing the supreme principle of all obligation among men. It is the command in Lev. xix. 18, "Thou shalt love thy neighbour as thyself." "Tis true that the extent of the obligation implied in this command seems to be restricted by the language which immediately precedes it: "Thou shalt not avenge, nor bear any grudge against the children of thy people." From this it might be inferred that neighbour, even in its widest application, cannot be understood here to comprehend more than the children of Israel. But to this restriction there are obvious objections. In the first place, the term עn., which is rendered here by neighbour, 1 is one of wider extent in its origin as well as in its actual

${ }^{1}$ This use of neighbour and its equivalents in modern translations of the Bible is due to the fact that the Hebrew term which it represents is in the Septuagint rendered by $\dot{ } \pi \lambda \eta \sigma l o \nu$, literally, the person near. But the Hebrew equivalent of $\pi \lambda \eta \sigma l o \nu$ is An adrantage of the Septuagint version might perhaps be found in its obtruding the fact that, of course, effective love cannot be dissipated over all human beings indiscriminately, but must be practically limited to those with whom we are brought into contact. Still the unavoidable vacillation of meaning in the original term as well as its translations may explain the perplexity or quibble involved in the question, "Who is my neighbour?" (Luke x. 29 ; cf. ver. 36 ). 


\section{SUPREME IDEAL OF CHRISTIAN LIFE}

use than its English representative. Originally it expresses the idea of comrade or friend, but widens in its application to any other person. The conmand in question, therefore, might be fairly rendered, "Thou shalt love another as thyself." This wider rendering is enforced by the additional fact that the same chapter of Leviticus, in vv. 33 and 34 , gives a eommand of a similar nature with the word stranger, that is, foreigner (ㄱ.), substituted for neighbour. ${ }^{1}$ It might appear, indeed, from the language of this command as if its obligation were restricted to foreigners residing among the Hebrews. It would thus merely give a cosmopolitan range to the sentiment which Viruil puts into the mouth of Dido,

"Tros Tyriusque mili nullo diserinine agetur.".

But this restriction is certainly not stated explicitly, nor can it be said to be even implied, in other expressions of the same general attitude, or in special provisions of " the Law," with regard to foreigners. So far as general attitude is concerned, the Hebrew was enjoined simply to "love the foreigner." 3

The treatment of foreigners in Hebrew law appears thus to be an embodiment in statutory form of the sentiment which from the very begimning of moral eivilisation has found expression in the custom of hospitality. It is worth noting that this custom is found in all its vigour even anong races living under the rudest limitations of tribal morality. It is, therefore, a pleasing

1 It is gratifying to find this conelusion fortified by the greatest Hebrew scholar of his day. "The expression of the second elause in Lev. xix. 18 (cf. vv. 16-18) must be complemented (ergïn t) lyy ver. 34 (Ewald's Altcrthümcr, p. 290, note ${ }^{2}$, 3rd cd.).

2 Eneid, i. 574.

3 Dent. x. 19. Even the earlier Ex. xxii. 21 and xxiii. 9 are in the same unqualified form. Speeial provisions equally unqualified with regard to foreigners are noticed below. 
and foreible proof of the fact that, even under its most unfavourable restrietions, moral life ombodies a spirit that is universal in its implieations. The obligations of hospitality have, in general among primitive men, been invested with a peeuliarly imperative charaeter, overriding almost every other elaim, even that of natural relationship, with which they might eome into eonflict. Usually, therefore, wherever religion forms a prominent feature of life, they have been eonseerated by its sanetions. This consecration of the antique virtue reaches its highest form in the divine command to the Israelite to love a foreigner as he loves himself, and to treat foreigners generally with the same regard for their rights which he aceords to the ehildren of his own people. Nowhere, in fact, have the obligations of hospitality been interpreted after a loftier ideal or surrounded with more sacred assoeiations than in early Hebrew life. This ideal has found a singularly beautiful embodiment in the well-known story preserved from primitive patriarchal life in the eighteenth and nineteenth ehapters of Genesis. Here the point of the narrative evidently turns upon the eontrast of the liberal hospitality of Abraham with the inhospitality and inhuman atrocity displayed by the people of Sodom. Frequent allusions in the New Testament as well as in the Old indieate how deeply the tragic horror of the story had burnt itself into the memory of the people as a warning against brutal degradation. But the tender pathos of the story also, as encouraging the kindly elaims of hospitality, continued to be felt even at a late period, even among Hellenistie Jews. The writer of the Epistle to the Hobrews, it will be remembered, enjoins his readers " not to negleet hospitality, for by it some have entertained angels unawares." 1

${ }^{1}$ Heb. xiii. 2. The Revised Version renders $\phi_{\iota} \lambda o_{\zeta} \varepsilon v i \alpha$ by its etymological meaning, "love of strangers." 


\section{SUPREME IDEAL OF CHRISTIAN LIFE}

But with all the liberal humanitarianism of Jewish law some other facts come into unpleasant contrast. The Old Testament and the New alike reveal among the Jews a condition of moral sentiment far short of their humanitarian ideal. In our estimate of this shortcoming, however, we must not be unfair to the Jews. The defects of their moral life were not peculiar to them, but common to all races of men. Almost every section of the Christian Church itself has shown a tendency to restrict divine favour within the limits of its own organisation, however narrow that might be, and to treat those who dissent from it as if by that very act they were separated from Christ, alienated from the spiritual commonwealth of God, and foreigners to the covenant of promise which God has made with all .His children. ${ }^{1}$ Such a restriction of spiritual sympathies is apt to become peculiarly rigid when ecclesiastical regulations are not merely binding on those who voluntarily become members of a church, but are made part of a civil code to be enforced by the power of the State. This identification of the State with the Church, this blending of civil and religious life, was evidently the national ideal aimed at by the leaders of the Jewish people during a considerable part of their history. It may be questioned, indeed, whether the theocratic ideal of the Jews ever went further, in practice or even in theory, than that of pagan antiquity in general, than that of Western Christendom at the period of the Reformation, than that of Calvin during his régime in Geneva, than that of the New England colonies during their early history. Still this conversion of religion into a national institution tended among the Jews to substitute for humanitarian enthusiasm the passions of a narrow > patriotism, to degrade their glorious national inheritance 
from being a faith for all humanity into a religious privilege reserved for a peculiar people; and therefore, even to some of their finest minds, the truth embodied in their national faith had to come at last as an astounding revelation, that God is no respecter of persons, but that in every nation any man who fears Him and acts righteously is acceptable to him. ${ }^{1}$ Accordingly, to the nations in general - the oris or Gentiles-the attitude of the Jews during a great part of their history was one of aloofness, of repellent isolation. Even the wider and more frequent intercourse with the nations, which resulted from the Babylonian deportations, from the Macedonian and Roman conquests, seemed only to deepen the horror of the Jews for the unfamiliar usages of Gentile life, and especially for its polytheistic forms of worship. Their nationalistic exclusiveness was thus fanned into a fiercer fanaticism. This evidently made them a perplexing study to Gentiles. It created in some of the best minds of the pagan world an antipathy far stronger than the mere dislike of foreigners, which may be met with among all races. This antipathy finds frequent expression in literature, and appears to have been founded on the belief that the Jews cultivated a peculiarly narrow nationalism, putting themselves into antagonism with all the rest of mankind. In the opening chapters of the fifth Book of the Historice of Tacitus, to which reference has already been made, the Jews are described as characterised by unfaltering fidelity among themselves, but towards all others by the hatred of foes: "Apud ipsos fides obstinata, misericordia in promtu, sed adversus omnes alios hostile odium." 2 In a passage which betrays a lack of accurate information as astonishing as that of Tacitus, his older contemporary Juvenal satirises the Jews as if they were ${ }^{1}$ Acts x. 34, 35.

${ }^{2}$ Historiarum, v. 5. 


\section{SUPREME IDEAL OF CHRISTIAN LIFE}

required even hy their law to refuse the most trivial act of kindness to any but the eireuncised :

"Non monstrare vias eadem nisi saera colenti, Quæsitum ad fontem solos deducere verpos."

(2) But the spirit of the Hebrew ideal involves humanity in its intent as well as in its extent. This also is involved in the intrinsically religious aspect of the ideal. The command to be holy because God is holy, makes the divine holiness the standard for human conduct. Now that holiness is sometimes represented exclusively in the stern repellent aspect of a justice that is unbending, irreconcilable. But that is very far from being the exclusive character in which Jehovah was conceived. He was indeed thought of as One who is of purcr eyes than to behold evil, ${ }^{2}$ One who will by no means clear the guilty, but visits the iniquity of the fathers upon the children and upon the children's children, upon the third and fourth generation. ${ }^{3}$ Nor can there be any truthful conception of the Supreme Being which does not force the mind into reverent awe before the inviolability of His laws. But any one at all familiar with the Old Testament knows how frequently and prominently Jehovah is represented under another aspect. The very passages in which His character as the severe Judge is portrayed, are those which also describe Him as "long-suffering and of great mercy, forgiving iniquity and transgression." 4 This is, moreover, the divine character which Jehovah demands of His people-to love merey, to relieve the oppressed, to judge the fatherless, to plead for the widow. ${ }^{5}$ Accordingly we are not surprised to find in the Jewish

1 Satire, xiv. 101, 102.

"Hab. i. 13.

${ }^{3}$ Ex. xxxiv. 7 ; Num. xiv. 18.

${ }^{4}$ See the same passages in Exodus and Numbers.

${ }^{5}$ See, for example, Isa. i. 17 ; Mie. vi. 8. 
law numerous provisions which indicate a kindly consideration for the weaknesses of humall nature and for the defeneeless members of soeiety. The penal code, indeed, as already mentioned, was at times severe. But it was not more barbarous in its severity than the eriminal law of the world generally down to the early part of last century. It seems, moreover, to have been tempered by mild rules in its administration. Thus the remarkable limitation of scourging to "forty stripes save one" 1 seems to have been a practieal preeantion against any mistake of excess in eounting, suggested by the Deuteronomie form of the law which warns against exceeding the "certain number" of forty "lest thy brother should seem vile unto thee." 2

In other regulations also the same kindly spirit shines forth. Most readers of the Old Testament must have noticed the unique provision for the gathering of the various harvests, which takes from the owners the gleaning of the fruits left on tree or field, and reserves these "for the stranger, for the fatherless, for the widow." ${ }^{3}$ This points to an ethical coneeption of property which forms one of the pleasing features of Jewish law. It subordinates proprietary rights to the rights of personality, while it is not too strong to say that, in a great deal of Gentile legislation, the elaims of man as a moral being are ignored when they come into con- $v$ flict with the claims of property. The ethical restriction of a proprietor's rights and the ethical extension of his obligations run through the whole Jewish code. It is not necessary to go into minute detail. But in view of the industrial problems of our own day it is interesting to note the kindly protection which Jewish law afforded to the wage-earner, dependent as he is upon employers of labour for his living. "Thou shalt not oppress an hired servant that is poor and needy, whether he be of
12 Cor. xi. 24.
2 Dent. xxv. 3.
${ }^{3}$ Deut. xxiv. 19-21. 


\section{SUPREME IDEAL OF CHRISTIAN LIFE}

thy brethren or of thy foreigners that are in thy land within thy gates: in his day thou shalt give him his hire, neither shall the sun go down upon it; for he is poor and he setteth his heart upon it: lest he cry against thee unto Jehovah, and it be a sin unto thee." 1

The pathos which gives a tone to this regulation of free labour is felt also in the regulations with regard to slaves. The restrictions and obligations imposed on the slaveholder give to the institution of slavery among the Jews a humanity that contrasts favourably with the inhuman harshness which has characterised that institution almost everywhere else in the modern world as well as in the ancient. ${ }^{2}$ One of the most scholarly students of Hebrew history feels justified in asserting that, though the religion of Jehovah (das Jahvethum) could not abolish slavery at once, "yet no ancient religion is, by its origin as well as by its inextinguishable bent, so decidedly opposed to it, or at least to everything inhuman in it, and already prepared so surely for its abolition." 3

The humanity embodied in the legislation concerning human labourers, slaves as well as freemen, finds a further expression. It is extended also to the lower animals that man employs to help him in his work. Hebrew law thus anticipates that comparatively recent expansion of moral sentiment which expresses itself through the Societies for the Prevention of Cruelty to

${ }^{1}$ Deut. xxiv. 14, 15 ; cf. Jer. xxii. 13-17 ; Mal. iii. 5. It is the spirit of this injunction, and especially of the warning against its violation, that glows in the indignant language with which St. James denounces the oppressors of the toiling poor in his day (v. 3).

2 A summary and interesting explanation of the Hebrew laws in regard to slavery is given in Wallon's Iristoire de l'Eselavage dans l'Antiquité, vol. i. pp. 1-20. Ewald also gives a fine critical summary in his Alterthümer, pl. 280-288 (3rd ed.). The Bible Dictionaries may, of course, be consulted with profit on the subject. The spirit of these laws is fairly indicated in such passages as Ex. xxi. 2-11; Lev. xxx. 41-55.

${ }^{3}$ Ewald, op. cit. p. 282. 


\section{EVOLUTION OF THE CHRISTIAN IDEAL $\sigma_{3}$}

Animals, and in the legislation enacted by their influence. The law which prohibits the muzzling of an ox employed in threshing corn, ${ }^{1}$ at least as it was interpreted by intelligent Hebrews to enforce the justice of a labourer's claim to his wages, ${ }^{2}$ seems to ascribe to animals rights which are not always recognised by those who seek a philosophical foundation for the duties men owe to inferior creatures. In other passages these duties seem to be founded rather on a claim which is urged by many who question the technical right of a lower animal-the claim, namely, of man's own humane sensibility, which is sure to be blunted by cruelty of any kind. ${ }^{3}$ This kindly consideration for the lower animals does not indeed go so far as Buddhism. But this peculiar feature of the great Oriental religion is logically bound up with its attitude towards life in general, which makes the transmigration of souls a prominent object of thought. And it may be claimed for ancient Jewish law, that it recognises the demands of morality in this direction more fully than the legislation or even the moral sentiment of the Western world generally till comparatively recent times.

The same spirit of kindliness, contrasted with a stingy adherence to bare justice, runs through the interpretation of human relations in general. This is especially clear

1 Deut. xxv. 4.

21 Cor. ix. $9 ; 1$ Tim, v. 18.

${ }^{3}$ It must suffice to refer here to Lev. xxii. $27-28$; Dent. xxii. $6-7$; cf. Ex. xxiii. 4, 5. It is well also to bear in mind that the Sabbath law secures rest from work for animals as well as for human labourers, whether slaves or free (Ex. xx. 10 ; Deut. v. 14). Critical inquiry will hardly allow us to cite in this connection the somewhat enigmatical, thrice-repeated commandment not to seethe a kid in its mother's milk (Ex. xxiii. 19, xxxiv. 26 ; Deut. xiv. 21). It is just possible that the prohibition is directed against some pagan rite which was well enough understood by this description at the time, though distinct trace of it has since been lost. But in the simple meaning of its language it seems to refer to a combination which is not really cruel in itself, which only shocks the human sentiment of tenderuess. 


\section{SUPREME IDEAL OF CHRISTIAN LIFE}

in Deuteronomy, with its restatements of the Law in such a form as to prevent its spirit from being lost in a superficially literal interpretation of its requirements. The prophets went further still in this direction, correcting at times without scruple the statutory enactinents of an earlier legislation so as to bring them into unison with equity. The Talmud also shows that many of the great rabbis perpetuated and developed the generous spirit of Deuteronomic and prophetic interpretations of the Law. Even the minor morals, as they are sometimes called unfairly,-the courtesies of social intereourse,-receive due attention in rabbinical decisions. There are instances, at times amusing, at times pathetic, in which a provision of law receives a curious application from the judicial assumption that it must have meant to avoid the infliction of needless pain, to show all possible consideration for the feelings of men. ${ }^{1}$

The deeper views of the moral life found some prominent representatives among the Pharisees of the Christian era. This great sect has not always received its due in history. It represented, in fact, a much greater variety of moral character and of religious thought than is commonly supposed. In one passage of the Talmud a distinction is drawn between seven different types of Pharisees, but of these only one is treated as worthy of the name; and for Christian Ethies it is profoundly significant that this pre-eminence is founded on the fact that the class thus honoured consists of those who "do the will of their Father in heaven, because they love Him." ${ }^{2}$

1 Some examples of this are given in a popular but interesting book, Tales from the Talmud, by E. R. Montagne (1906). See l'l. 43-48, 129, 130, 189-190.

2 Babyl. Sotah, 22b. This part of the Babylonian Talmul is not given in Rodkinson's English translation. The 'Talmulic description of the seven types of Pharisees will be found in the admirable essay on the Talmud by Enanuel Deutsch. See his Literary Remains, p. 29. 


\section{EVOLUTION OF THE CHRISTIAN IDEAL 65}

In the interpretation of "the Law" a distinctly marked cleavage among the Pharisees originated shortly before the birth of Christ. It was connected with the divergent teachings of the two great rabbis, Hillel and Schammai. Of these the former represented that liberal style of interpretation which aimed mainly at realising the spirit of the law, while the latter insisted on rigid adherence to the strict letter of its requirements. The divergence of the two masters gave rise to two antagonistic schools, whose controversies take a prominent place in the Talmud, and appear to have been carried on till a late period, even after the destruction of Jerusalem. Of Hillel some beautiful utterances have fortunately been preserved, and they reveal a teacher whom our Lord would surely have characterised as being "not far from the kingdom of God." 1 It is difficult to avoid the impression that the scribe, whom Christ actually characterised in these words, belonged to the school of Hillel. At least the language of the scribe, which called forth our Lord's commendation, breathes the finest Hillelite spirit. That language recalls especially the famous saying of Hillel, which is sometimes regarded as an anticipation of the so-called "golden rule" of Christ. The story of the incident which called forth this saying is a good illustration of the general contrast in character betwcen Hillel and his rival. The story has been often told, but it bears repetition. For our purpose, as will presently appear, even verbal accuracy is of some moment here; and therefore the story is given in the words of the Talmudic narrative as translated by Rodkinson: "A Gentile came to Schammai, saying, "Convert me on the condition that thou teach me the whole Torah while I stand on one foot.' Schammai pushed him away with the builder's measure he held in his hand. He there-

$$
1 \text { Mark xii. } 34 .
$$




\section{SUPREME IDEAL OF CHRISTIAN LIFE}

upon came to Hillel, and the latter accepted him. He told him, "What is hateful to thee do not urto thy fellow! this is the whole law. All the rest is commentary to this law; go and learn it.'"1

Modern writers very commonly render Hillel's saying in a form which brings it much nearer the saying of Jesus. Thus even Mr. Deutsch gives, "Do not unto another what thou wouldest not have another do to thee" ${ }^{2}$ and a large proportion of those by whom it is quoted adopt similar language. ${ }^{3}$ But in none of these variations is the negative form of the saying obliterated. Yet it is surprising to find that some writers deal with the saying as if there were no difference between it and the positive precept of Christ. Professor Sidgwick ${ }^{4}$ notices this confusion in Hobbes ${ }^{5}$ and Puffendorf, ${ }^{6}$ and evidently Mr. Deutsch also treats the two sayings as identical. ${ }^{7}$ It is, therefore, worth while to draw attention

1 Babyl. Sabbath, 31a. The version given here will be found in Rodkinsou's translation, vol. i. p. 51.

2 Literary Remains, p. 31.

3 Foreign writers show the same laxity. Thus Stapfer, in his $L a$ Palestine dans le T'emps de Jésus Christ (p. 286, 6th ed. 1892), gives "Ne fais pas a ton prochain ce que tu ne vondrais pas qu'il te fit."

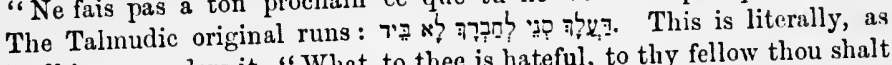
Rodkinson renders it, "What to thee is hateful, to thy fellow thou shalt not do." It corresponds, therefore, almost verbatim with the saying in

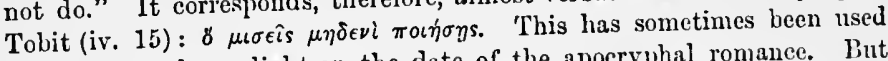
by critics to throw light on the date of the apocryphal romance. But Jost points out (Gcsehichte des Judenthums, vol. i. p. 259, note 1) that the saying is not claimed as original by Hillel, is eited rather as if it were in familiar curreucy. Certainly that is the aspect which it presents in Tobit among a number of noral commonplaces uttered by a dying father to his son.

4 History of Ethics, p. 166, note 1.

5 Compare, in The Leviathan, 1. 144 with p. 153 (Molesworth's edition).

6 De Jure Nature et Gentium, ii. 3, 13. Puffendorf avowedly follows

Hobbes. Neither makes any reference to the sonrces of the two formula confounded.

7 Loc. cit. 


\section{EVOLUTION OF THE CHRISTIAN IDEAL 67}

to the fact, though it has often been pointed out, that in its form at least the precept of Hillel differs very distinctly from that of Christ. The real significance, indecd, of formulæ so general as these, must always depend on their practical application in particular cases. But certainly in its logical implications the formula of Hillel does not necessarily carry social morality beyond that attitude of negative justice which requires merely abstinence from injury, and therefore it falls far short of the positive iujunction requiring us to do to others what we would have them do to us.

In the Gospels it is true that the Pharisees are sometimes denounced unsparingly, though it appears that in this respect the language of the Gospels is outdone by that of the Talmud. ${ }^{1}$ But such denunciations should not be allowed to exclude from our view the indications, which the Gospels themselves contain, of a noble character in some of the class. It is evident, for example, that Jesus did not maintain an attitude of irreconcilable estrangement from the Pharisees as a class, but was quite ready to accept the friendly hospitality offered by some. ${ }^{2}$ Again, at a critical period of our Lord's career, it was "certain of the Pharisees" who took the kindly precaution of warning Him against the cruel design of Herod Antipas. ${ }^{3}$ It should not be overlooked, moreover, that Nicodemus is expressly designated as "a man of the Pharisees"; ${ }^{4}$ and from his association with Joseph of Arimathea in a brave expression of affectionate rever-

1 See Dentseh, op. cit. p. 29.

2 Luke vii. 36 , xii. 37 .

${ }^{3}$ Luke xiii. 31 . It is true that the report of Herod's design is often explained either as an artifice of his own or as an invention of the Pharisees who intervened to induce Jesns to leave Galilee, if not to give up His work altogether ; but sueh interpretations seem to found on the utterly unhistorical assumption that no Pharisee could be eapable of sueh generosity towards Christ.

${ }^{4}$ John iii. 1. 


\section{SUPREME IDEAL OF CHRISTIAN LIFE}

ence for Jesus immediately after the Crucifixion, ${ }^{1}$ it may fairly be taken for granted that the latter was of the same religious sentiments. Joseph and Nicodemus are merely individual examples of the sympathy which the teaching of Jesus found among the better class of the Pharisees. It is worth noting that at the trial of Jesus no Pharisee is spoken of as having been present. For that process, whether it was technically legal or illegal, the official Sadducees were alone responsible. It is therefore entirely in accordance with our historical knowledge to assume that this class furnished most of the early converts to the Christian faith. In fact, so little incompatibility did these converts find between their new faith and their old, that in the Acts of the Apostles many of them are spoken of as still belonging to "the sect of the Pharisees" after their conversion. ${ }^{2}$ It is an additional fact of significance-of all the greater significance that it is apt to pass unnoticed by being a testimony of silence-that all through the Acts, while every persecution of the primitive Church is expressly charged upon the Sadducees, ${ }^{3}$ the Pharisees never appear in a hostile attitude. The first formal prosecution of the apostles breaks down before the courageous and sensible pleading of Gamaliel, grandson of Hillel, and representative of his school. ${ }^{4}$ It was a pupil of Gamaliel's who first grasped in its full significance the world-wide mission of Christianity, and became its most influential missionary among the Gentiles. Paul, in fact, never ceased to cherish, with a feeling of honourable pride, the memory of his connection with the Pharisees. ${ }^{5}$

To critical reflection it may appear that the Jewish law, as explained above, reveals a condition of society

1 John xix. 39.

Acts v. 33-42.

2 Acts xv. 5.

${ }^{3}$ Acts iv. 1-6, v. 17.

- Acts xxii. 3 , xxiii. 6 ; Phil. iii. 5. 


\section{EVOLUTION OF THE CHRISTIAN IDEAL 69}

which has not yet differentiated the legal and the moral spheres. This is true, but the defect is not a peculiarity of Jewish history. It is a common feature in the social evolution of all races. It is also true, however, that a great gain is implied in the differentiation of the two spheres. For, as law aims at the enforcement of its $r$ obligations by physical compulsion, it is of supreme importance that these obligations should be restricted to external conduct without requiring any particular motive by which it must be inspired. It is of the essence of persecution to apply to the spiritual life methods of compulsion which are applicable only to an external act. But however beneficial this separation of law and morality may be, it is not without its drawbacks. For the real value of any action by a moral agent depends on his motive or intention; and therefore, abstracted from this, the action can never be estimated fairly. But this is the very abstraction at which law aims. Accordingly from of old it has been a familiar truth that law, under its limitations, can secure but a rough sort of justice at the best-may even, if rigidly enforced, involve serious injustice at times. It is therefore not wholly a gain to the higher life of men to separate external conduct thus completely from its internal spirit. Not only do the legal relations of men suffer in consequence, but their moral life is liable to a more serious deterioration. For they are apt to fall into the illusion that their obligations are completely fulfilled, if observed merely in their literal interpretation as bodily actions, whatever their mental stimulus may be. It has, therefore, been the general task of moral reformers in all ages to remind the world that there is no security for rectitude of conduct, except in the trained habits of mind which constitute moral character, that before all other cares a guard must be 


\section{0 \\ SUPREME IDEAL OF CHRISTIAN LIFE}

kept upon the heart, since out of it are the issucs of life. ${ }^{1}$

The lack of any rigid distinction between law and morality in Jewish legislation is not without an advantage for our purpose. That legislation becomes thus a clearer indication of the moral ideal of the Hebrew race. We are thus brought back to the kernel of the whole matter, that, as the moral ideal of the Hebrews is intrinsically religious, so their religion is intrinsically moral. In the history of religion may be traced universally the same tendency which has just been described as vitiating the moral life of the world, the tendency to substitute a bodily exercise which is of little profit for that spiritual culture which alone possesses moral or religious significance. ${ }^{2}$ The old Testament contains much painful evidence to prove that Jews yielded to this tendency like other people, but it would be a violation of historical truth to suppose that they were sinners above all others in this respect. The utter externalism of pagan cults in the ancient world was surely a more ghastly caricature of all genuine religion; and in the history of Christendom there have been periods when genuine Christianity seemed to vanish from the common life of the Church, and was forced to create a new atmosphere for itself in voluntary communities devoted specially to the culture of the spirit. This degeneration of religious life is always aggravated by a cause which has been already referred to as narrowing the moral ideal. It is a cause that operated with peculiar force among the Jews. Their religion, as we have seen, was a national institution, but it was an institution woven into all the relations of social life more intricately perhaps than any other national religion. The power of such an institution among any people is

1 Prov. iv. 23.

21 Tim. iv. 8. 
intimately connected with the social position of the priesthood, who are invested with the offices of its administration. Now, among the Jews the priesthood seems to have been at least as powerful a body as under any other civilisation. Not only were they very numerous in proportion to the whole population; they formed an hereditary caste which, as Josephus tells us, took the place of a nobility in other countries. ${ }^{1}$ With this potent influence to support the external organisation, and to enforce the external ritual, of the national religion, it is no wonder that the religious life of the people should have degenerated at times into an observance of legal ceremonies as an obligation of civic life.

But to all this there was a counteracting influence which reveals another side in the religious life of the Hebrews. That life was moulded by another institution of somewhat unique character; at least it would be difficult to find among any other people a class of men exactly corresponding to the Hebrew prophets. The full significance of these men in Hebrew history need not be discussed here. It is sufficient to recognise their function as interpreters of moral and religious truth in perfect freedom from the professional prejudices and rules of the official priesthood. No literature surpasses in impassioned vigour the prophetic denunciations of that corruption which degrades religion into a routine of ceremonies having no intrinsic connection with the spiritual condition of the worshipper. On one hand, the pagan idea that an offended deity may be placated, a reluctant deity wheedled into consent, by any conjuring trickery of a priest, is tossed aside with scorn, while it is pointed out that such a meaningless pretence of

1 See the opening sentences of his Autobiography. The historian was evidently proud of his noble origin. 


\section{SUPREME IDEAL OF CHRISTIAN LIFE}

worship can only be offensive to the Being whom it seeks to please. On the other hand, the worship which Jehovah demands is declared to be such conduct in daily life as will show that the worshipper obeys the supreme requirement of the divine will by loving his neighbour as limself. "To what purpose is the multitude of your sacrifices unto Me? saith Jehovah. ... I delight not in the blood of bullocks, or of lambs, or of he-goats. . . . Your new-moons and your appointed feasts My soul hateth. . . . I am weary to bear them. .. Put away the evil of your doings from before Mine eyes. Cease to do evil, learn to do well." 1 "Wherewith shall I come before Jehovah? . . . Will Jehovah be pleased with thousands of rams, with ten thousand rivers of oil ? . . What doth Jehovah require of thee, but to do justly, and to love mercy, and to walk humbly with thy God?" 2 Such utterances of Hebrew prophecy form a perennial inspiration for the religious life of the world; and Christian preachers, seeking to illustrate and enforce the nature of true worship, continue to draw their texts and lessons largely from this source.

\section{§3. Evolution of the Moral Ideal among the GreEks}

For the scientific study of the evolution of ethical ideas the materials furnished by Greek literature are vastly richer than any that can be found elsewhere in the ancient world. Notwithstanding the enormous literary losses which the disasters of time have entailed, there is still extant enough of the literature of Greece to enable us to trace with some degree of clearness the development of its moral ideal.

So far as the extension of that ideal is concerned, the ${ }^{1}$ Isa. i. 11-17.

2 Mic. vi. 6-8. 


\section{EVOLUTION OF THE CHRISTIAN IDEAL}

Greeks were fettered by a peculiar but powerful hindrance in the very splendour of their civilisation. This led to a differentiation in their minds between themselves and other races, quite as marked as that which the Hebrews drew between themselves and the Gentiles. The word Kápßapos, which to the Greek mind denoted at first only a foreigner, came gradually to imply what its derivatives in modern languages express exclusively, the lack of that culture of which the Greeks were the pre-eminent representatives in the ancient world. This mode of thought created a racial pride which prevented the pure Greek from placing himself easily on the same moral plane with men of another race. It is true that a great intellect like Plato's could indulge in logical sport over his countrymen for their illogical division of men into Greeks and barbarians, pointing out that on the same trivial principle cranes might form a zoological classification with themselves in one group and the rest of animals in another. ${ }^{1}$ But the very splendour of Plato's genius brings into more startling distinctness the narrowing influence of his racial prejudice. His ideal reconstruction of moral and social life, daring though it is in its radicalism, seems never bold enough to conceive a society so completely transformed as to embrace within the range of equal rights and obligations all races of mankind. Aristotle is generally felt to be harsher even than his teacher in his general attitude towards the barbarian world. ${ }^{2}$ Both, in fact, though representing perhaps the highest reach which philosophical intelligence

I The Statesman, p. 262.

2 It may appear strange that no reference is hero made to the common story of Socrates having freed himself from Hellenic prejudice so completely as to describe himself as a citizen of the world. A similar story is told of Diogenes the Cynic. Though frequently repeated, both stories are void of critical foundation. Their history is curious and 


\section{SUPREME IDEAL OF CHIRISTIAN LIFE}

has ever attained, give but an inadequate representation of the moral life even of the Hellenic race. For all literature, and especially the literature of philosophy, is the product of a mental condition of comparatively high culture. Its value, therefore, as an exponent of human life must always be estimated with a discount of the fact that it is not the voice, is at best only now and then an echo of the voice, of the uncultured minds who form the great majority of the people in all places and at all times. This is eminently true of Greek literature in the fourth century before Christ, the age of Plato and Aristotle. It represents merely the limited class of men whose social position allowed them the leisure required for a high mental culture. It is true that in the Athens of that period the leisured class formed a larger proportion of the whole population, of the whole free population at least, than in any similar period of any other State. But it must not be forgotten that it is this class alone that is really represented by the literature of the time. Its two great thinkers especially are frankly, naïvely aristocratic in all their modes of thought, in all their sentiments with regard to human life. The common man, the toiler, whether he be a freeman or a slave, makes no show in their writings except as an abstraction to form a subject of philosophical speculation. This attitude towards the great body of mankind must inevitably mar the moral ideal even of the greatest thinkor. In such an attitude no man can attain an undistorted view of that perfect

intercsting, but would learl ns into letails beyond onr limits. Here it must suffice to say that for the first, the earliest and only independent anthority is Cicero, writing nearly four centuries after the time of Socrates, and that the other rests on the authority of Diogenes Liiertius, who lived five centuries after his namesake of Sinope. No prineiple of historical criticism could justify us in accepting either story uuler these conditions. 
catholicity, that full humanitarianism, which nust $\checkmark$ characterise any moral ideal with a claim to reality.

But though no man can rise above the insuperable limitations of his environment, every scientific thinker carries in his thought a principle which implicitly transcends his limitations. For all scientific thinking is a process of reasoning; and reasoning can make no progress, can reach no conclusion, except by proceeding along the line of some truth which is of universal application. Accordingly we are not surprised to find, in the great ethical systems to which Athens gave birth in the fourth century before Christ, ideas potent enough to break through the barriers of racial or social prejudice. Some of these ideas will be noticed more appropriately when we come to treat the virtues of Christian life in detail. Here we shall give prominence to those features of ethical thinking among the Greeks which indicate a general enlargement of the moral ideal both in its extent and in its intent.

1. Already in the fifth century before Christ the intellectual ferment, excited by historical movements which were profoundly affecting traditional modes of life and thought throughout the Hellenic world, had naturally stirred the minds of men most powerfully on the problems of morality and religion. The particular form which the ethical problem assumed was the question, whether the laws of morality rest on an eternal foundation in the immutable nature of things, or are mercly conventional arrangements of different countries and different ages, whether these laws have their origin $\dot{\epsilon} \nu \phi \dot{v} \sigma \in \iota$ or merely $e^{\nu} \nu \nu$ ó $\mu$. Those who adopted the former alternative recognised as a necessary inference, that the moral law is endowed with an universal validity transcending the limitatious of time and place. The ethical teaching of the time, therefore, began to assume 


\section{SUPREME IDEAL OF CHRISTIAN LIFE}

an humanitarian tone which implicitly bore down the prejudices of race. This teaching beeame familiar to the audiences that crowded the theatres of Greece, and a fine poetic skill was often displayed in investing the popular religion with a new significance by foreing its myths to beeome vehieles of the eternal truths of a spiritual morality. Of this teaching an illustrious example is given in the noble speech of Antigone refusing to obey King Creon when he forbade her to perform the last religious rites which her dead brother could claim. She reminds the king that his commands cannot set aside the divine and eternal order:

"For not by Zeus were these promulgated,

Nor by the Right divine of the underworld;

It was not they laid down these laws for men.

Nor did I deem thy edicts of such force

That, but a mortal, thou could'st go beyond

The unwritten and unfailing laws of God.

Not of to-day or yesterday, these are

of all time; none know when they came to light." 1

2. The same teaching is involved in the treatment of ethical questions by the great thinkers of the following century. For their treatment is scientific, is an endeavour to find a scientifie foundation for moral law; and such a foundation can be obtained only in the laws of man's nature and the general order of the universe. But a morality resting on the nature of man and of the universe implicitly takes an humanitarian range, however inconsistent with such a range may be the ideas or sentiments of any inclividual noralist on particular problems of moral life. Aceordingly, not-

1 Antigone of Sophloeles, 450-457. The impress which these noble words made upon the Greek mind is strikingly indieated by the fact that in a chapter of Aristotle's Rhetoric (i. 13), which will be referred to

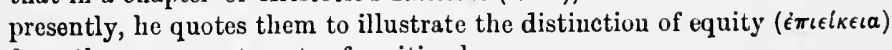
from the mere enactments of positive law. 
withstanding the Hellenic and aristocratic prejudices of Plato and Aristotle, throughout their writings there gleams many a brilliant reflection of the loftiest ethical ideal. This appears most conspicuously in their exposition of the social side of morality. In the ancient classification of the virtues, which has been already mentioned as having originated with Plato, the social side of moral life is distinctively represented by

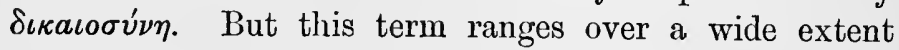
of meaning, from what is understood by justice in its stingiest interpretation up to a conception so unrestricted as to be practically coextensive with the whole range of moral obligation. Accordingly the dialogue of Plato, which gives the fullest exposition of his Ethics and Politics, and even of his Philosophy as a whole,- - the Republic,-grows out of a question with regard to the

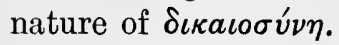

Aristotle's treatment of the same virtue leads to a similar expansion of meaning. He distinguishes, in fact, explicitly between the narrower and the wider interpretation of its obligations. In its narrower sense it implies nothing beyond the requirements of justice that are embodied in law or custom, and then it ranks merely as a particular kind of virtue. But when the spirit rather than the rigid letter of these requirements is observed, justice is elevated into a lofty range of obligations which become comprehensive of all virtue. ${ }^{1}$ Nor should it be overlooked that this ideal of justice is spoken of as being already so familiar to the Hellenic mind, that it had found embodiment in a proverbial

1 Eth. Nic. v. 1 and 2. The two meanings can be traced in the New Testament, where the word is of frequent occurrenee. Sometimes, though by no means uniformly, the higher meaning is in English translations rendered by righteousness, the other by justice. In Rom. v. 7, sicacos represents evidently a less perfect virtue in contrast with a $y a \theta 0$, thongh the English versions translate it by righteons. 


\section{SUPREME IDEAL OF CHRISTIAN LIFE}

saying, "In justice all virtne together is contained,

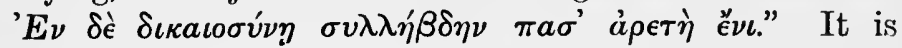
also asserted, apparently in the words of a faniliar quotation from some book now lost, that "neither the evening nor the morning star is so worthy of admiration." 1 Accordingly, though Aristotle's ethical code never takes on an explicitly humanitarian character, it shows throughout the humanising influence of an implicit humanitarianism.

For it becomes obvious that some virtues of finer mould are necessary to supplement the limitations of justice in its narrower sense. Thus, for example, it must be recognised that, on account of their generality, laws can be applicable only to the average of cases, can never take account of the varied and complicated circumstances that distinguish individual actions. The rigid enforcement of a law, therefore, in unusual cases may often, as already observed, ${ }^{2}$ be attended with injustice, sometimes of serious character. Accordingly Aristotle points out the necessity of justice itself taking a larger range to correct any narrow interpretation of its requircments. This larger range of justice he denotes by the term é $\pi \iota \epsilon i \kappa \epsilon \iota a$, which we commonly render equity. Though the more technical exposition of this higher virtue is given in his Ethics, ${ }^{3}$ yet his idea is perhaps more clearly conveyed in a brief passage of the Rhetoric ${ }^{4}$ which has been often quoted for its beauty: "Equity appears as something just, but it is justice going beyond written law. . . It is equitable to make allowance for human nature; to have a regard, not for the law, but for the lawgiver; not for the lawgiver's

${ }^{1}$ Eth. Nic. v. 1, 15. The proverb occurs among the verses of Theognis. The other saying has not been traced. See Sir $\Lambda$. Grant's note on the passage in his edition of the Ethics.

${ }^{2}$ See above, 1. 44.

s Eth. Nic. v. 10 ; Eth. Eud. iv. 10.

${ }^{4}$ Rhetoric, i. 13. 
language, but for his meaning; not for the act, but for the intention; not for part, but for the whole; not for what sort of person one is at the moment, but for what he is always or for the most part; to remember the good received rather than the evil, and the good received rather than the good done; to endure injury with patience; to be willing to settle differences by reason rather than by action; to choose arbitration rather than judicial procedure; for the arbitrator looks to what is equitable, but the judge (mercly) to the law; and for this reason arbitration was devised in order that the equitable might prevail."

Another social virtue is recognised by Aristotle as akin to equity, transcending the bare requirements of justice as commonly understood. To it he gives the name of é $\lambda \epsilon u \theta \epsilon \rho$ cót $\eta s$, liberality. The name, like its Latin equivalent which has been taken over into English, implies in its etymology an attribute peculiarly characteristic of the freeman. That is to say, liberality is not a service such as may be wrung from a slave by compulsion. It is rather a service rendered spontaneously in the spirit of freedom. Accordingly it gives prominence to that positive aspect of social obligations which is apt to be ignored in any rigid definition of justice. ${ }^{1}$

3. Aristotle's recognition of liberality, however, bore fuller fruit in the Stoical school. It was connected by a more irresistible logic, not only with the general principles of their Ethics, but with the whole system of their Philosophy. It is true, the whole school arose under conditions peculiarly favourable for thinking out a theory of moral life that went beyond nationalistic prejudices and the defective ideals attendant upon these. The old system of small independent States, around which the patriotism of the Greeks had twined, had

1 See above, p. 46. 


\section{SUPREME IDEAL OF CHRISTIAN LIFE}

been completely shattered by the political and military triumphs of the Macedonian monarchy. By the same cause even the old line of demarcation between the Greek and the barbarian was being in some measure obliterated by a vast number of Greeks being brought into political and social relations with barbarians, while numbers of barbarians sought with eager appreciation the advantages of Greek culture. Most of the early Stoics were either not of pure Hellenic blood, or had been brought up in one or other of those Hellenic colonies that were in close daily contact with the conquered Oriental races. None of these thinkers had been prejudiced by the influences of the exclusively Hellenic environment which had moulded the earlier moralists. They were all able, they were in fact forced, and must have become accustomed, to look at the problems of moral and political life from a point of view beyond Hellenic limitations. The influence of these historical circumstances was greatly enhanced by the progress of Roman conquests. These brought under one government a vast number of States which had been previously independent and often even hostile. The moral ideas of their citizens became thereby more easily detached from the obligations of distinct nationality. The loss of national independence, moreover, drove the citizens from all work for their old patriotic ideals, and compelled them to seek other ideals of life than those connected with civic service.

These historical conditions went to strengthen the moral reasoning of the Stoics. But it is only fair to say that they were the first great ethical school that reached humitarianism in morals as an inference logically necessitated by the principles of a philosophical systen. The Philosophy of the Stoics was an intensely religious system of thought. Its very kernel was the conception 


\section{EVOLU'TION OF THE CHRISTIAN IDEAL $8 \mathrm{I}$}

of the universc as, in the minutest incidents of its evolution, an embodiment and exponent of Perfect Reason. Man is, therefore, by his very nature participant in the Reason of the universe. It is his very nature to be reasonable, and he acts in accordance with his nature only when he acts in accordance with reason. Such action is his only good. It constitutes for him

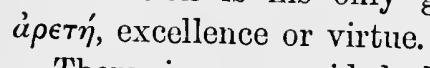

There is a one-sided development of this doctrine $r$ which has received an undue prominence in the common expositions of Stoicism. Since reason alone was recognised as having any rightful place, the emotional side of man's nature was denied any reasonable claim. It was, in fact, sometimes described as rò ẳoyov, the very essence of irrationality. The wise man, therefore, directing his life exclusively by reason, could make no terms with emotion at all. It must be wholly suppressed, and the ideal of virtue came to take on a predominatingly negative cast as consisting mainly in àmá $\theta \epsilon a$, complete freedom from emotional control. This attitude was not confined to the baser passions, which are universally admitted to be unfavourable, if not inimical, to virtue. It extended even to the purest and tenderest sentiments. Undoubtedly, therefore, the Stoical discipline seems at times to have resulted in a passionless severity or harshness of disposition; and it is for this reason that, when the term stoical is used, not as the proper name of a philosophical school, but as a common description of a certain type of men, it is understood to indicate this unattractive character.

But it would be historically unfair to suppose that this represents more than one side or even the most prominent side of Stoical morality. It does not represent at all the religious side, which brings the ideal of the Stoics into its most intiniate connection 


\section{SUPREME IDEAL OF CHRISTIAN LIFE}

with that of Christian moralists. For it must be remembered that, as the Stoic viewed all men as in common participant of the Divine Reason, he held that, so far, all men are made in the image of God, all are His children. The human race was thus conceived as united by an universal bond transcending all the particular relations by which it is divided into groups that are separate merely in space or time. As children of God they form one universal family or brotherhood. They belong not merely to the petty kingdoms of this world, they belong also to that sublimer community which embraces all reasonable beings, divine as well as human intelligences, forming a veritable kingdom of God. "To me as Antoninus," thought the great emperor, "Rome is fatherland; to me as a man, the world." 1 And, two centuries earlier, Cicero, expressing the best pagan thought at the Christian era, observes: "This whole world is to be viewed as one commonwealth of gods and men." 2

The germ of this ennobling conception seems to have exerted a quickening influence upon Stoical teaching from the first. The historical development of this germ, indeed, it is now impossible to trace in detail, for the writings of the earlier Stoics have all perished except in such fragments as happen to be quoted in works that are still extant. But the thought of men being the offspring of God must have been familiar among the Stoics by the middle of the third century before Christ, for it found expression by two at least of the poets of

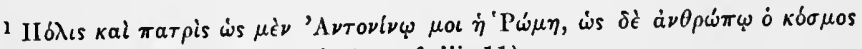
(M. Aurelius'Mcditations, vi. 44 ; cf. iii. 11).

2 "Universus hic nundus nna eivitas sit communis deormm atque hominum existimanda" (Le Legibus, i. 7, 28). The idea was common among the Stoies. Various expressions of it will be found in Hateh's Lecturcs on the Influcnee of Grcek Idcas and Usagcs upon the Christian Church, 1. 212, note 1 . 


\section{EVOLUTION OF 'THE CHRISTIAN IDEAL 83}

that period. One of these is Aratus, who as a countryman, if not a townsman, ${ }^{1}$ of St. Paul, is usually thought to have been in the apostle's mind when he made the quotation in his address before the Areopagus. ${ }^{2}$ The other is the Stoic Cleanthes, by whom a hymn containing the thought in question has come down to us. The leading ethical corollaries of this conception must have been definitely indicated long before the Christian era. The universal brotherhood of man, for example, is but another aspect of the universal fatherhood of God; and therefore we are not surprised to find that it is an idea which had passed even into general literature in the second century before Christ. It finds expression in the often-quoted verse of Terence:

"Homo sum; humani nihil a me alicnum puto," 3

which is said by Augustine to have evoked an outburst of sympathetic applause from the whole theatre. It is an interesting fact, as illustrating the evolution of moral sentiment, that, apparently about this time, the adjective humanus, used in this passage, came to receive the two

1 Soli in Cilicia is commonly named as the birthplace of Aratus, though one authority gives Tarsus. $\mathrm{He}$ is also said to have received Stoical education, and is even ranked by Zeller, though not from any explicit record of the fact, among the pupils of Zeno the Stoic (Philosophie der Griechen, vol. iii. 1, p. 35, note 1 (English translation, p. 44, note 1). See also the article on Aratus in Smith's Dictionary of Greek and Roman Biography and Mythology). The language in which St. Paul introduces his quotation-" as certain even of your own poets have said "- would imply that ho thought of it as a not uncommon expression in Greek poetry. It may be added that Chrysippus, recognised among the ancients as the second founder of Stoicism and its chief literary expositor, was also born at Soli or, aecorling to other not improbable accounts, at Tarsus.

${ }^{2} \Lambda$ cts xvii. 28.

${ }^{3}$ Heautontinoroumenos, i. 1, 25. Terence, it is worth remembering, was, as a Carthaginian and a slave, outside the circle of Roman and aristocratic prejudice. 


\section{SUPREME IDEAL OF CHRISTIAN LIFE}

meanings which English differentiates by human and humane. ${ }^{1}$ The abstract noun humanitas was used to denote not only the whole human race without regard to its divisions, but also the distinctive characteristics of man as man; and these were conceived as including the refinement of intellectual culture, as well as those kindly sentiments and virtues which assert their claims as soon as the common kinship of men is recognised." The moral ideal came in this way, by reasoning from the very nature of man, to yield a place to virtues of the mild, gentle, tender type which had received but scant recognition in earlier codes, especially of the Stoical school. This appears from the position they receive even in Cicero's De Officiis. As already mentioned, this is avowedly an adaptation of a similar Greek treatise by the Stoic Panætius. It may, therefore, fairly be taken as representing Stoical Ethics at the time when its original appeared, and that must have been a good part of a century before its Roman version. In fact, it is scarcely going too far to say that Cicero's work represents the best thought of the Greco-Roman world on the problems of moral life before the Christian era. In it the obligations of social morality are explicitly separated into two groups, characterised as justitia and beneficentia, while the nature of the latter is indicated more fully by being described also by the terms liberalitas and benignitas. ${ }^{3}$ The kindlier features of social virtue come into greater prominence among the later Stoics, especially in the writings of Seneca. But here the teaching of Stoicism runs parallel in time to that of

1 The Greeks had long before implicitly indicated the eonnection between these two ideas in their idiomatic abstractions, $\tau \dot{\alpha} \alpha \dot{\alpha} \theta \rho \omega ́ \pi \epsilon \iota a$ and $\tau \dot{a}$ à $\nu \rho \omega \dot{\pi} \boldsymbol{\tau} \iota \boldsymbol{a}$.

2 Speaking of clementia, Seneca says : "Nullam ex ommibus virtutibus magris homini convenire, cum sit nulla humanior" (De Clcmentia, i. 3. 2).

${ }^{3}$ De Officiis, i. 7 and 14-17. 


\section{EVOLUTION OF THE CHRISTIAN IDEAL 85}

Christianity, and it is difficult to ascertain to what extent they were independent of one another. If there is no evidence of any direct mutual reaction, they were both in common moulded by the great movements of human history during the period of their concurrent existence.

In tracing the growth of humanitarian morality among the Greeks, it should not be forgotten that, like other races, they recognised, even from prehistoric times, that primitive virtue of hospitality which is, in fact, humanity in its simplest form. The Greeks, too, like the Hebrews and other races, had invested the obligations of hospitality with a sacred character. The worship of Zeus Xenios, the divine protector of the stranger-guest, seems to have been universal throughout the Hellenic world. ${ }^{1}$ It may be added that Virgil, who fairly represents the best pagan culture of his time, has, again in language put into the mouth of Dido, identified Jupiter with the Greek Zeus as the divine guardian of hospitality:

"Jupiter, hospitibus nam te dare jura loquuntur," etc."

But in ancient pagan Ethics there is one feature which must not be overlooked, as it affords perhaps the most interesting anticipation of the Christian ideal. This is the prominence generally given to friendship. Here, too, moral sentiment is consecrated, and consecrated by a form of religious thought similar to that employed in the consecration of hospitality. In the worship of Zeus Philios the supreme deity of Greek religion came

${ }^{1}$ Farnell, in his Cults of the Greek States (vol. i. pp. 73-74), gives an interesting and scholarly illustration of this particular cult in its ethical import. By the way, however, the narrative, which he cites from the Life of Apollonius of Tyana, by Philostratus, is, of course, not to be accepted as history. The article on Hospitium by Dr. Schmitz in Smith's Dictionary of Antiquities, is also worth consulting.

2 Aneid, i. 731. 


\section{SUPREME IDEAL OF CHRISTIAN LIFE}

to be characterised as the Patron of Friendship; and this cult, like that of Zeus Xenios, seems to have spread extensively over the Hellenic world. ${ }^{1}$ We are not surprised, therefore, to learn that the cultivation of friendship carries us back even into the mythical period of Greek history. In the legends of Theseus and Pirithous, of Achilles and Patroclus, of Pylades and Orestes, we have a traditional survival of the moral halo which from the beginning the Greek mind seems to have thrown around the relation of friendship among men. This halo lost none of its splendour, it was rather reflected with a richer light, when speculative thought turned to the phenomena of moral life. The philosophical schools, in fact, generally formed some sort of friendly association among their members. This was pre-eminently the case with the earliest school that attained a regular organisation. The Pythagoreans, indeed, were much more of a moral, even a religious, brotherhood than a mere school of speculative thinkers. Consequently some of the most glorious illustrations of friendship still held before us for imitation, such as the story of Damon and Phiutias, are drawn from the circle of the Pythagoreans.

Of later treatises on the subject, the germ is probably to be found in the conversations of Socrates, which Xenophon has recorded in his Memorabilia, ${ }^{2}$ as well as in the description, which the same work gives, of the actual relation which Socrates maintained with his friends. $^{3}$ Plato's dialogue, Lysis, is a discussion on friendship, evidently written while the young philosopher was still under the domination of the ideas which his master had inspired. In later years he returns to the subject in Phocdrus, and it becomes once more the

${ }^{1}$ Farnell, op. cit. vol. i. pp. 74-75.

2 Book ii. chs. 4-6.

${ }^{3}$ Ibid. chs. 7-8. 


\section{EVOLUTION OF THE CHRISTIAN IDEAL 87}

dominant theme in the Symposion when he had reached the maturity of his literary art. But the exposition of friendship by Aristotle, if less splendid than that of his master, satisfies more fully the requirements of philosophic thought. The prominence which it holds in his moral code may be gathered from the fact that his chief ethical treatise, the Nicomachean Ethics, devotes two of its ten books-the eighth and the ninth-entirely to friendship. The Christian idea, that all the lower and narrower obligations of social morality are absorbed in love, has rarely been expressed with finer pith than in the beautiful utterance, "When men are friends there is no need of justice, though when they are just they still stand in nced of friendship, and what is best in justice itself seems to be of the nature of friendship." ${ }^{1}$ The value also, the very necessity, of friendship in human life is forcibly expressed at the very opening of Aristotle's discussion: "Without friends no one would choose to live, even if he had all the other blessings of life." 2 The ethical theory of Epicurus, from its hedonistic and egoistic features, might have been expected to lower friendship from the rank generally assigned to it among the Greeks. But the very opposite was the case. In the Epicurean school the most exacting obligations of friendship were enforced by example as well as by precept. This receives a fine illustration in a recorded saying of the master. One of his disciples had proposed the introduction of communism into the "Garden " after the example of the Pythagoreans. "No," was the reply of Epicurus, "such a system is for men who distrust one another, and those who do so are not friends." ${ }^{3}$

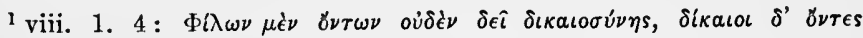

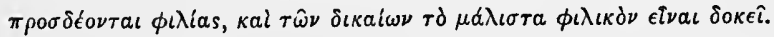

2 Ibid. viii. 1. 1.

${ }^{3}$ Diogenes Laertius, x. 6. The reply of Epicurus seems but an echo 


\section{SUPREME IDEAL OF CHRISTIAN LIFE}

Cicero, with his habitual stateliness of phrase, has in his Laclius given to the Romans the best that he could gather from his Greek teachers on friendship. ${ }^{1}$ A century after the time of Cicero, Seneca also wrote a work on the subject, but only a fragment of it has come down to us. In an oration of Dio Chrysostom there is a passage which gives perhaps the loftiest expression in all literature to the religious aspect of friendship. If the Christian ideal extends the friendly attitude of will beyond a narrow circle of associates to mankind at large, that ideal may be said to have been grasped in the eloquent language of the great rhetorician. The language is put into the mouth of Phidias, the sculptor of the Olynipian Zens, who is represented as expounding the divine ideal which he sought to embody in that great production of his art. After various characteristics of Zeus are described, the god is said to have been called Philios, "because he brings all men into harmony, wishing them to be friends, and no one to be at emnity with any other." Some two generations after Dio we come upon the Toxaris of Lucian, a treatise based on the somewhat clumsy device of a discussion between a Greek and a Scythian as to which of their nations has produced

of Aristotle. He had already objected to communism on the ground that it wonld take away the virtue of liberality in regard to property,

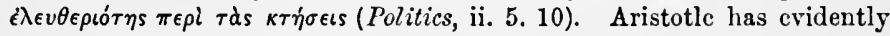
influcnced Christian thought on the subject of communism all through the history of Christendon, but naturally in Christian literature charity takes the place of liberality. The catholic doctrine has found embodiment in the Thirty-eighth Article of the Church of England: "The riches and goods of Christians are not common as touching the right, title, and possession of the same, as certain Anabaptists do falsely boast. Notwithstanding, cvery man ought, of such things as he possesseth, liberally to give alms to the poor according to his ability." Compare Aristotle's P'olitics, ii. 5. 8.

${ }^{1}$ See also the briefer sketch in De Officiis, i. 17 .

2 Oration xii. $413 \mathrm{R}$. 


\section{EVOLUTION OF THE CHRISTIAN IDEAL 89}

the more splendid examples of friendship. The interest centres mainly on the examples cited; but, coming as it does from the greatest comic writer of his age, the work forms a significant proof that the ethical thought of paganism found a charm in the subject to the very last. 


\section{CHAPTER III}

THE MORAL IDEAL REVEALED IN THE NEIV TESTAMENT

IN last chapter it has been shown that the evolution of morality throughout the history of man has been towards an ideal in which love forms the supreme standard, the universal inspiration of life. It was also shown that this evolution indicates the necessary trend of intelligence, and that, therefore, the more completely the finite mind enters into communion with the Infinite, the nearer it comes to the supreme ideal of morality. But communion of the finite mind with the Infinite is the essence of religion; and therefore, as we have seen, it is by an intrinsic evolution of intelligence that the moral consciousness passes over into the religious. Now Christianity, it need not be repeated, is not merely a system of morals; it is also a religion. It is a religion which finds its realisation in moral life; but it is also a morality so unconditional in its claims that it, too, can find no adequate realisation except in religious life, that is, in a life which brings man's finite will into harmony with the Infinite Will that forms the order of the universe.

We have now to see that this is the ideal of morality enjoined in the authoritative sources of information with regard to Christianity, the collection of primitive Christian literature forming our New Testament. In 


\section{THE MORAL IDEAL REVEALED}

this inquiry it will be convenient to consider first the teaching of Christ Himsclf, then that of His apostles.

\section{$\S 1$. The Moral Ideal in Christ's Teaching}

When we come to analyse Christian morality in its various characteristics, we shall find that there is one feature of Christ's teaching which is peculiarly prominent and significant. That is the infinite value which $\mathrm{He}$ attaches to the individual soul, the moral personality. This estimate is sometimes viewed only in its subjective effect. In that aspect, of course, it calls for earnest and strenuous exertion to save the soul from those moral corruptions by which alone it can be lost. But the estimate has an objective effect as well. It imparts an awful intensity of meaning to the command which requires a man to love his neighbour as himself. The egoistic anxiety of the Christian to avoid a loss which is infinite for himself becomes indissolubly associated with a corresponding altruistic anxiety to save others from the same irreparable calamity. This association is, in fact, so indissoluble, that, as we have seen, the egoistic aim itself can never be realised except through the altruistic. This fact necessarily gives a deeper intensity and spirituality to all the ethical teaching of Christ.

In that teaching a prominent place must always be assigned to the Sermon on the Mount. The main drift of this discourse, as has often been pointed out, seems evidently to be the elevation of morality into the sphere of the spirit. It enjoins the necessity of emancipating moral life from enslavement by the mere letter of particular rules of conduct into the freedom of an universal spiritual motive. All the virtues are thus carried back to their source in personal character. 


\section{SUPREME IDEAL OF CHRISTIAN LIFE}

That eharacter is, in fact, what we mean by virtue. For the obligations of morality are not fulfilled by the performance of an external action which does not represent the habitual disposition of the mind. A law may be obeyed in all its requirements so far as external eonduct is concerned; but if obedience has been yielded with reluetance, the law cannot in propriety be said to have been fulfilled at all as a moral law. It is obeyed, as we say, in the letter, but not in the spirit. The man who would willingly disobey it, and is restrained only by some non-moral consideration, has committed sin in his heart. ${ }^{1}$

But the spirit of social morality, as we have seen, $\sim$ cannot be satisfied with a stingy assent to the bare requirements of justice. Accordingly, in the Sermon on the Mount, the Master protests against any such niggardly interpretation of the moral law. $\mathrm{He}$ insists on the inspiration of love as alone adequate to meet the law's demands. Two elauses of the sermon are peculiarly illustrative of this.

1. In the first, $\mathrm{He}$ criticises an old eonception of social morality which may be deseribed as the Retaliation - Theory. It has exerted a practical influence on criminal jurisprudence in early periods of civilisation all over the world, and in this form it has come to be spoken of as the Jus Talionis. It is obviously a primitive attempt to give a mathematical exactness to the "determinate" demands of justice by treating them as capable of quntitative calculation. It is therefore not surprising to learn that it should have found favour as a speculative theory with a school like the Pythagoreans, who were the first to see the vast significance of number, that is, of exactly formulated quantity, in the seientific explanation of the world. ${ }^{2}$ In

1 Matt. v. 28.

2 Aristotle, Eth. Nic. v. 1. 1. 
its simplest form, indeed, retaliation endeavours to restore exactly the quantitative equilibrium in life that has been disturbed by a wrong. It exacts from the wrong-doer precisely the same loss or suffering which he has inflicted, so that he shall be reduced to the same condition as the victim of his wrong. It claims "life for life, eye for eye, tooth for tooth, hand for hand, foot for foot." 1 No more rigorously determinate justice could be invented. But it does not represent the morality enjoined or allowed by Christ. He demands a totally different spirit in the social relations of men in general, a totally different attitude in particular to those who are guilty of wrong. "I tell you not to withstand the wrong-doer. But whosoever shall smite thee on thy right cheek, turn to him the other also; to him who willeth to go to law with thee and to take from thee thy coat, give up thy cloak also; whosoever shall summon thee to go one mile, go with him two; to him that asketh of thee give, and from him that willeth to borrow of thee turn not away." 2

The right interpretation of this language is indicated by its prominent feature. That feature is implied in all moral teaching, though it is peculiarly explicit here. For morality would lose its proper significance if it were not viewed as having to do with the conduct of living moral agents. Now the language employed here, as generally elsewhere by our Lord, shows that $\mathrm{He}$ is not speaking in the style of a speculative thinker about action in the abstract. Every injunction in the passage contemplates a certain attitude towards persons. It is

${ }^{1}$ Deut. xix. 21 ; ef. Ex. xxi. 24 ; Lev. xxiv. 17-22. The first passage is peculiarly remarkable (1) from its occurring in Deuteronomy, (2) from its specific detail, (3) from its being precedcd by the stern injunction, "Thine eye shall not pity."

${ }^{2}$ Matt. v. 38-42. 


\section{SUPREME IDEAL OF CHRISTIAN LIFE}

persons that form the subject and object in every

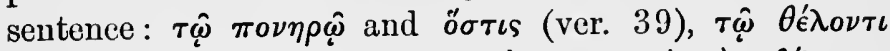

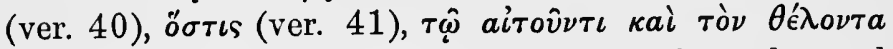
(ver. 42). Here, therefore, $\tau \hat{\varphi} \hat{\varphi} \pi o \nu \eta \rho \hat{\varphi}$ is to be understood not as a neuter, denoting evil or wrong in the abstract; by analogy with the other expressions in the passage it must be taken as a masculine, referring to the concrete wrong-doer. This is confirmed by the general fact that the abstract phrases, which form a common expression of Greek thought, are by no means so familiar to the Hebrew mind. It is not, therefore, resistance to wrong in itself that is prohibited here. 2 Such a prohibition is, in fact, inconceivable. All virtue implies resistance to evil, and such resistance forms a characteristic feature of Christ's whole life. The interpretation of the special injunction of ver. 39 in crass literality breaks down before the action of our Lord when He was smitten by one of the rude officers of the high priest. ${ }^{1}$ It is not, therefore, resistance to evil that His words forbid; they describe rather the attitude towards the wrong-doer that is demanded by the highest morality. He had begun by referring to the attitude allowed and even enjoined in an earlier society. That was the attitude of retaliation or revenge. It is that attitude that is forbidden,- the attitude of resisting the evil-doer by retaliating upon himself the evil he has done. Paul has caught the spirit of his Master's teaching in the noble language in which he enjoins the Roman Christians not to recompense evil by evil, but to overcome evil with good. ${ }^{2}$ He sees that we do not overcome evil by returning it upon the evil-doer; by such a return we rather allow the evil to overcome ourselves. For retaliation or revenge is the expression of an evil will, a will to do evil to another. It means,

${ }^{1}$ John xviii. 23.

${ }^{2}$ Rom. xii. 17-21; cf. 1 Pet. iii. 9. 
therefore, that evil is being perpetuated, has won a triumph instead of being overcome; and the hereditary feuds of every society in which revenge has been allowed furnish innumerable tragic proofs of this effect. Retaliation is thus directly antagonistic to the supreme principle of morality, antagonistic to that love which is the will to do good. For the will to do good, as supreme, is unconditional in its obligation. That obligation, therefore, does not lapse on condition of another person doing evil to us. The supreme moral law, the law of love, can never give us a licence to do evil to any man; and the only victory over evil is that which is gained when for evil good is returned. Thus the forbidding of retaliation forms a natural and logical transition to the next clause of the Sermon on the Mount-the clause bidding us to love our enemies, ${ }^{1}$ that is, to maintain the will to do good even to those who will to do evil to us. The intrinsic connection of thought between the two clauses is indicated by the manner in which the precepts of both are intermingled in the narrative of Luke. ${ }^{1}$

2. The second of the two clauses may, in fact, be regarded as the complementary positive to the negative precept of the first. It, too, adopts the method of antithesis for exposition. Like the first, it opens with a reference to the morality of a ruder age, which has always given way before a clearer moral intelligence. That morality has not only prevailed generally in primitive societies, but it finds innumerable representatives still among the types of rude morality that survive in the most civilised communities; and even the finest minds may lapse into it at times when moral intelligence is obscured by passion. This ruder morality is, in fact, a form of retaliation. It is a 


\section{SUPREME IDEAL OF CHRISTIAN LIFE}

retaliation of affection. It requires us to render to others exactly the kind of affection they give to us, love for love, but also hatred for hatred. It is embodied in the brief formula, "Thou shalt love thy neighbour and hate thine enemy."

On this formula two explanatory remarks are required. In the first place, it is desirable to recall the explanation of the word ncighbour, which was given in last chapter. ${ }^{1}$ It was there explained that the Hebrew original has no connection with mere neighbourhood, but expresses rather the idea of comrade or friend. This meaning brings out the antithesis between the two parts of the formula more clearly than the Greek or the English translation. It thus appears to mean, "Thou shalt love thy friend and hate thine enemy." But, in the second place, it must not be assumed that the formula represents "the Law," either in its letter or in its spirit. Enongh has been said in last chapter to show that the command to love one's neighbour as oneself is to be interpreted in no narrow or niggardly spirit. ${ }^{2}$ The other injunction to hate an enemy, it need scarcely be said, is not only to be found nowhere in the Old Testament, but is explicitly repudiated again and again. The Israelite is forbidden to cherish hatred or grudge, or to seek revenge. ${ }^{3} \quad \mathrm{He}$ is not even allowed by mere neglect to let an enemy suffer an injury which he could prevent." The actual sentiment also of the best minds went more definitely in this direction. In $\mathrm{Job}^{5}$ and in the Psalms ${ }^{6}$ horror is expressed at the thought of requiting even an enemy with evil. Stories also of generous forbenrance towards enemies are related evidently with sympathetic pathos. ${ }^{7}$ In the Book of

\footnotetext{
${ }^{1}$ See above, p. $55 . \quad 2$ Ilid.

' Ex. xxiii. 4-5.

${ }^{5} \mathrm{xxxi} .29-30$.

${ }^{3}$ Lev, xix. 17-18.

${ }^{7}$ Gen. xlv. 1-15; 1 Sam. xxiv. 7-22; 2 Kings vi. 21-23.
} 


\section{'IHE MORAL IDEAL REVEALED}

Proverbs, ${ }^{1}$ which reveals a tendency of later reflection, perhaps through Hellenic influence, to seek a foundation for moral law in laws of human nature, the injunction to do good rather than evil to an enemy is fortified by reference to the effect of the better requital upon the enemiy's own mind: "Thou shalt heap coals of fire upon his head."

But against all this stands the fact, already noticed, of the rude morality which finds satisfaction in revenge, -a morality which does not pass away with the vanishing of uncivilised tribes, but survives to corruptr still the highest eivilisations of the world. In the natural tendency of human life which this fact reveals, it is enough to say that the Hebrews were like other races. Between neighbouring nations, even of kindred origin, there is apt to be more or less friction, creating a certain amount of national antipathy on both sides. This friction was rendered unusually irritating in the case of the Israelites on account of the marked contrast of their ideals with those of their pagan neighbours. The general antipathy thus originated was sometimes intensified by unhappy incidents of international history. Thus, during the migration of the Israelites,

${ }^{1}$ Prov. xxv. 21-22. Paul quotes this in the passage which has just been eited from Rom. xii. 20 ; ef. Prov. xxiv. 17, 29. Occasionally the opinion is still met with, that the duty of forgiving injury is an innovation by Christ upou all the previous ethical teaching of the world. It is therefore worth while to be reminded that His teaching on this point draws a significant confirmation from the fact that it is in harmony, not only, as we see, with the best ethical thought of the Hebrews, but also with that of tho Greeks. Plato is peculiarly explicit on the subject, not in the Hebrew form of a seer's intuition, but in the form of logical evolution which was the characteristic excellence of Greek thought. See Crito, 49, and Republic, 334-335. He puts his teaching indeed into the mouth of his idealised Socrates; but the real Socrates, at least as reported by Xenophon, does not rise to the ideal of his great pupil in a conversation which gave a fitting opportunity for its expression. See Xenophon's Mem. ii. 6. 35 . 


\section{SUPREME IDEAL OF CHRISTIAN LIFE}

the Amalekites had shown an irritating unfriendliness, and had thereby naturally excited a bitter sentiment of national enmity. ${ }^{1}$ This natural sentiment is made the ground of later legislation, and significantly in Denteronomy itself, requiring the Israelites to exterminate the whole of the hated race. $^{2}$ After the settlement in Palestine, Hebrew prejudice against surrounding nations-Philistines, Edomites, Assyrians, Babylonians-was perpetuated by repeated outbreaks of hostility from generation to gencration. Hatred of these pagan races came, therefore, to be viewed as an essential element in the character of an Israelite loyal to the ideals of his own race; and, as in regard to the Amalekites, such hatred was sometimes represented, even by the prophets, as if it were an obligation imposed by the God of Israel. Malachi, for example, deseribes Jehovah as proving His love for Israel by the fact that $\mathrm{He}$ hated Edom, had laid waste his mountains, and made his heritage an abode of jackals. ${ }^{3}$ There is not within the compass of the Psalter a lyric of purer poetic beauty, and it would be diffieult to find in any literature a wail of more tender pathos from an exiled patriot than the 137th Psalm. Yet it is rendered simply impossible for the expression of Christian sentiment by the savage joy with which the singer exults over the prospect of revenge: " $\mathrm{O}$ daughter of Babylon, who art to be destroyed; happy" shall he be, that rewardeth thee as thou hast served us; happy shall he be, that taketh and dasheth thy little ones against the stones."

There was, therefore, enough in Jewish life, as there is enough in human life at all times, to call for the inculcation of a higher morality than that which gives love merely where love is returned. Such a morality
? k.x. xrii. 8-16.
2 Deut. xxv. 17-19.
3 Mal. i. 1-4. 


\section{'THE MORAL IDEAL REVEALED}

is not the morality of love at all. For love is no mercenary barter in which both parties bargain for an equivalent in kind. Real love goes forth freely to do good without thonght of compensation. This is the purport of Christ's injunction: Love not merely those who prove themselves to be friends by loving you in return; but "love your enemies, do good to them that hate you, bless them that eurse you, pray for them that despitefully use you." 1 That is merely another way of saying that the soeial relations of men are not to be limited by any miserly conception of what strict right may demand or strict obligation may enforce. Such a conception yields but a very imperfect morality, such as is recognised even by publicans and Gentiles. ${ }^{2}$ But the Christian must aim at the perfection of His Father in heaven; and that perfection consists in the fact that $\mathrm{He}$ does not confine the gifts of His love to those who give an equivalent in return. On the contrary, "He maketh His sun to rise on the evil as well as the good, and sendeth rain on the just as well as the unjust." ${ }^{3}$

1 The reading here is somewhat uncertain, but the best eritieal opinion seems to regard the received text of Mattliew as amplified from Luke. The latter is, therefore, given here from the Revised Version. See Luke vi. 27 and 28, and eompare the Revised Version of Matt. v. 44.

${ }^{2}$ See Matt. v. 47 in the Revised Version.

${ }^{3}$ Matt. v. 45. Some eommentators quote appropriately the fine thought of Seneea: "Si deos imitaris, da et ingratis beneficia; nam et sceleratis sol oritur, et piratis patent maria" : If you seek to be like God, do good even to the ungrateful; for the sun rises even to the wieked, and the seas are open to pirates. (De Beneficiis, iv. 26.) The passage is of interest as showing at least the trend of the best ethical thinking in the pagan world while Christianity was making its first advanees there. But of course it is by no means impossible that, as Christian tradition believed, Seneca may have eaught some hints of Christian teaching from his brother Gallio (see the apoeryphal correspondence of Paul and Seneea based on Acts xviii. 12-17), if not from other sourees. The prominence thus given to the benefieent aetion of nature is 


\section{IOO SUPREME IDEAL OF CHRISTIAN LIFE}

The gist of this higher morality is embodied in an injunction, which our Lord describes to His disciples as a new commandment, that they should love one another as He loved them. ${ }^{1}$ This description seems most probably to be interpreted, not in the shallower sense of novelty or originality, but rather in the sense indicated by His later description of it as His own distinctive commandment. ${ }^{2}$ The purport also of the commandment is expanded by an immediate explanation, which is peculiarly striking in view of that lofty appreciation of friendship which the previous chapter has traced in the ancient world. The love which Christ enjoins upon His disciples makes them friends not merely with one another, but also with Himself. It emancipates them from any relation of bondage even to Him-a relation in which the slave ${ }^{3}$ does his work in unsympathetic ignorance of his master. The disciples of Christ become His friends by being raised into intelligent sympathy with the divine ideal of life which $\mathrm{He}$ communicates to them. As this ideal is the distinctive charge which they receive from Him, it becomes also the specific mark of discipleship, the peculiar feature of character by which they are to be distinguished in the world. "By this shall all men know that ye are My disciples, if ye have love one to another." 4 But this love must be no idle sentiment. The test of its genuineness is to be the fact of its bearing plentiful fruit. ${ }^{5}$ And it is gratifying to learn

certainly more in harmony with moral and religious thonght than the horrid phrase which has become embedded in legal terminology, describing as the "act of God" any calamity duc to causes beyond human control.

1 John xiii. 34.

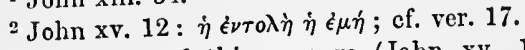

3 The force of this passage (John xv. 13-15) is weakened in the

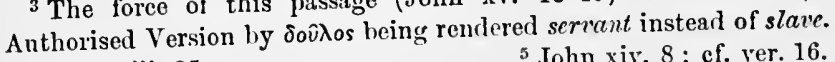

${ }^{4}$ John xiii. 35.

${ }^{5}$ John xiv. 8 ; cf. ver. 16. 
that it stood this test. In the life of the early Chureh the mark of diseipleship was reeognised. This is ecrtified not only by the authority of Christian writers like Tertullian, ${ }^{1}$ but more significantly by the testimony of opponents like Lucian. This humourist treats Christianity in the spirit of fun in which he plays with all forms of religion, and which gives to his writings their dominant feature. But in the only important passage in which he refers to the Christians of his day, he pays a signifieant, though indireet, tribute to their moral character. He amuses himself at their expense because their simple loving-kindness makes them easily the dupes of a charlatan. ${ }^{2}$

1 Tertullian's Apologeticus, 39.

2 See the story entitled, from it's hero's name, Peregrinus Proteus. The whole story, it appears to me, may be characterised, in the language which F. C. Baur applies to the melodramatic death-scene at its close, as "without doubt a pure fiction, Ohne Zweifel eine reine Fiktion" (Die drei ersten Jahrhunderte, p. 398). It is, therefore, futile to inquire whether the Peregrinus of Lucian was ever connected with the Christian Church. We liave first to learn whether he ever existed. The story, indeed, like all good fiction, is true as a pieturo of its time. It may be admitted also that it is true, so far as it goes, in giving a brief glimpse of contemporary Christian life. The hero, while in Palestine, is said to have attached himself to the Church, to have attained some of its highest offices, and become so notorious in his new profession that he suceecded in being thrown into prison. The Roman governor, indeed, seeing through his motives, deprived him of the glory of martyrdom by dismissing him with eontempt; but the good Christians ministered to his wants with generous luxury while he was suffering for their faith. This readiness to be duped obviously implies a corresponding readiness to go out in loving service without inquiring too curionsly into the merits of those whom the service is to benefit. Even the great humourist does not describe this characteristic of the Christians in terms of heartless contempt. His tone is, at worst, that of kindly pity for the guileless benevolence of the people who allowed themselves to be duped so easily by a charlatan like Peregrinus. The tone of Lueian appears far kindlier' than that of Mr. Bernard Shaw in Major Barbara, where the good soldiers of the Salvation Army are held up to amusement for allowing themselves to be imposed upon by tricksters of a very vulgar type compared with the accomplished Tartufe of Lucian's tragi-comic tale. 


\section{IO2 SUPREME IDEAL OF CHRISTIAN LIFE}

The kind of fruit demanded as a test of the genuineness of Christian love finds richly varied illustration in other teachings of our Lord. Such teachings are scattered through all the Gospel narratives, and some of them will be noticed in connection with particular applications of Christian love which have to be discussed in subsequent chapters. But there are two incidents in the life of Jesus which embody the general principle of His teaching in such a forcible form that they may be appropriately referred to here.

The first of these deals with a question which is inevitable in every society. That is the standard by which social rank is determined. The teaching of Christ refers specially, of course, to the principle of rank in the now society which $\mathrm{He}$ had come into the world to establish, and contrasts it with the principle prevailing generally in other societies at the time. Christ's explanation on the subject was called forth very naturally by a dispute which had arisen among His disciples as to which of them should be assigned the highest rank in the new social condition to which they were looking forward, and of which they thought and spoke as a kingdom with $\mathrm{Him}$ for the sovereign. ${ }^{1} \mathrm{He}$ begins by

$1 \Lambda$ comprarison of the three narratives of this incident reveals some slight but interesting variations. In Mattlew (xx. 20-23) the question is brought before Jesus by the wife of Zebedee, ambitious to seeure for her sons the chief places at the right hand and the left of His throne in His kingdom. Mark (x. 35-45) omits altogether the intervention of the mother, and ascribes the ambitions request directly to the sons. But both evangelists deseribe the other ten disciples as stirred to indignation against the two brothers, who were apparently regarded as attempting to "steal a march" on them. The clispute about their rank in the Master's kingdom thus became general, and it was when He observed the common ambition of the whole twelve that He gave His noble utterance on the subjeet. It is apparently this issue of the incilent alone that has interested Luke (xxii. 24-27), and it is certainly the one niomentous feature. He has, therefore, passed over as unessential to the main point the particular ambitions of James and John or their mother. He 
describing the principle of aristocratic ranking in other communities. These He speaks of as Gentile. This designation, however, must evidently be taken not as a racial distinction, but rather as descriptive of those moral characteristics with which it had come to be associated in the Hebrew mind. Among the Hebrews, as already mentioned, the word underwent a similar evolution to that of the word $\beta a$ ápßapos among the Greeks. ${ }^{1}$ The words pagan and heathen have a similar history. In their primary use they are applicable to the dwellers in those rural districts where pre-Christian forms of religion lingered long after the great urban communities had been converted. They have come, therefore, to denote a moral character opposed to the spirit of Christianity, and in that sense they might very properly be used to represent what Christ here means by the term Gentile. For His intention is obviously to describe the order of social ranks in what we should call a pagan or heathen community, that is, a community controlled by a moral spirit inconsistent with His ideal. In such a community superior rank is indicated by power to command the service of others, the nobleman exercising some kind of authority, the prince or chief wielding a complete dominion or lordship over the lower ranks in ordering them to do his will. All this Christ declares to be a reversal of the divine order of social ranks which $\mathrm{He}$ requires His followers to maintain. "Not so shall it be among you." In the new society which you are to form, if a man wishes to attain the rank of a noble he shall do so only by becoming the servant of the rest; if he is ambitious of being chief, he must be as completely at the service of introduces the teaching of Jcsus simply as occasioned by " a strife among them which of them should be accounted the greatest." With this passage it is worth while to compare one of kindrel significance in Matt. xxiii. 1-12.

${ }^{1}$ Above, p. 73. 


\section{IO4 SUPREME IDEAL OF CHRISTIAN LIFE}

the others as if he were their slave. ${ }^{1}$ And this revolution of social ranks is enjoined by Christ not as a mere theoretical precept, but as the principle which actually interpreted the significance of His own life: "For even the Son of Man came not to be served by others, but to serve them, and to give His life a ransom for many."

The second incident to which reference has beer. made puts some strain on the sympathetic imagination of the Western mind. The whole temper of Western culture has tended to incapacitate us for entering with full sympathy into the satisfaction which the Oriental mind finds in the expression of a truth by some picturesque symbol, by some significant act, rather than by language of prosaic accuracy. But if we quicken our sympathy with a phase of mental life so different from our own, we may catch a brief glimpse of the profound significance attaching to the vividly symbolic act, in which, as $\mathrm{He}$ was nearing the close of His life, the Lord of our spiritual civilisation gave expression to its sublime ideal. "He riseth from supper, and laid aside His garments; and took a towel, and girded Himself. Then He poured water into a bason, and began to wash His disciples' feet, and to wipe them with the towel wherewith He was girded. . . . So after He had washed their feet, and had taken His garments, and was set down again, He said unto them, Know ye what I have done to you? Ye call Me Master and Lord: and ye say well; for so I am. If I then, your Lord and Master, have washed your feet; ye onght also to wash one another's feet. For I have given you an example, that ye should do (to one another) as I have done to you." "

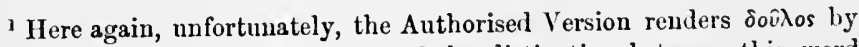
servant. Consequently the foree of the distinetion between this word and $\delta$ cácovos (translated minister) is wholly lost.

2 John xiii. 1-17. 


\section{THE MORAL IDEAL REVEALED}

Teaching so spiritual, so free from any narrow literalism in interpreting the practical requirements of moral life, might well be regarded as bearing the evidence of its own universality. But an attitude of destructive radicalism in the treatment of Christianity continues at times to assert that the Master's ethieal and religious ideas were restricted by the narrowest nationalism prevailing among His eountrymen, and that His teaching received its eosmopolitan interpretation first from the genius of St. Paul. It may, therefore, not be wholly needless to review the evidence from Christ's own life and language of the humanitarian eatholieity whieh charaeterised His teaching.

1. At the outset we eome upon one general feature which is traceable through all the language of our Lord from the beginning to the close of His life. That is, His use of the title "Son of Man." In regard to this title it is unnecessary here to enter into questions which still form subjects of controversy in the critieism of the Gospels. It is sufficient to take note of the fact that, in speaking of Himself, Christ uniformly uses this name in preference to any other. This fact beeomes all the more striking when it appears that, all through the New Testament, the name is never applied to Him by any other person, except in one solitary instance where it is used in what appears to be a quotation from His own words. ${ }^{1}$ Commonly, when any of Christ's

${ }^{1}$ The exception occurs in the exclamation of the first martyr, Stephen : "Behold, I see heaven open, and the Son of Man standing on the right hand of God" (Acts vii. 56). In the cireumstances in which these words were spoken, it was natural that the martyr should seek strengtll by reflecting on the calm endurance with which his Master had stood a similar trial; and when the glory of the victorious Saviour flashed on his soul, it was natural also that he should describe it in the very lan. guage in which it liad been foretold ly the Saviour Himself: "Hereafter shall ye see the Son of Man sitting on the right hand of power, and coming in the clouds of heaven" (Matt. xxri. 64). It may surely be 


\section{IO6 SUPREME IDEAL OF CIHISTIAN LIFE}

countrymen appeal to Him for pity, they addressed Him not as the Son of Man, but as the Soll of David. Both of these names seem to have been in use among the contemporaries of Christ as titles of the expected Messiah; and it is simply of infinite meaning that $\mathrm{Hc}$ uniformly avoided the purely national title which His countrymen preferred, and confined Himself to the unmistakably humanitarian title, the Son of Man.

2. Another feature of significance in the life of Christ is His general attitude towards the Samaritans, contrasted with the well-known prejudice of $\mathrm{His}$ countrymen against that people. This attitude appears (1) in the fact that $\mathrm{He}$ never seems to make any scruple against going through Samaria in His journeyings between Galilee and Judea; (2) in the story of the Samaritan woman ${ }^{1}$ (3) in His reply to James and John when they wanted to call down fire from heaven on a Samaritan village ${ }^{2}$ (4) in the parable of the Good Samaritan $;^{3}(5)$ in the remark which $\mathrm{He}$ made when it was observed that out of a number of lepers who had been healed the only one who returned to give thanks was a Samaritan: "None have been found to return and give glory to God save this man of another race." 4

regarded as merely one of the freaks of modern criticism, that a recent work by a Fellow of one of the Colleges in Oxford should lroach the historieal paradox that Christ never applied the title Son of Man to Himself (The Religion of All Good MLen, and Other Studies in Christian Ethics, by H. W. Garrod. London, 1906).
1 John iv. 5-42.
${ }^{2}$ Luke ix. 51-56.

3 Luke x. 30-37. It has been remarked that, while Jesus speaks of the Samaritans quite naturally under their proper name (ver. 33 ; ef. Matt. x. 5), the strict Jew avoided uttering the name as if it polluted his lips; and therefore the "lawyer," to whom this parable is addressed, answers the question as to which was neighbour to the man who had fallen among thieves by the description, "He that showed merey on him."

+ Luke xvii. 18. 
The import of these more general facts is confirmed by a number of particular incidents, of which the most important may be noticed here. Thus, at an early period of His life we find a request made to Jesus by the centurion of the Roman garrison at Capernaum. That this officer was not an Israelite either by birth or by religious profession, is absolutely certain from the remark of Jesus that He had not found so much faith even in Israel. Yet His conduct to the Gentile soldier ran directly in the teeth of the national prejudices of His countrymen. These prejudices, moreover, could not have been smitten with a more destructive blow than that struck by the memorable words with which $\mathrm{He}$ followed up the incident: "Many shall come from the east and the west, and shall sit down with Abraham and Isaac and Jacob in the kingdom of heaven, but the children of the kingdom shall be cast into outer darkness." 1

3 . These words, especially in their concluding clause, indicate that already our Lord had come into conflict with the ruling authorities of His country. This conflict was soon to deepen, and to give a dominant tone to His tcaching. He was thus led to explain in a varicty of ways that the Israelites had no exclusive claim to divine favour, but that the kingdom of God is open to all the races of men. The most specific and powerful utterances of this drift are to be found in the later parables of His life, which bear the impress cf having been spoken under the conviction that the enmity He had to face from the rulers of the people was hopelessly irreconcilable. The truth is faintly touched already in the parable of the Prodigal Son, ${ }^{2}$ in the attitude ascribed to the elder brother, combined with the kindly remonstrance of the father. It is also ${ }^{1}$ Matt. viii. 5-13.

${ }^{2}$ Luke xv. 11-32. 


\section{SUPREME IDEAL OF CHRISTIAN LIFE}

implied in the parable of the Pharisee and the Publican. ${ }^{1}$ It is indicated more clearly in the parable of the Labourers in the Vineyard,2 especially when interpreted in the light of the startling paradox with which it closes, that "the last shall be first, and the first last." There are two companion-parables, however, in which the meaning of the Great Teacher becomes unmistakable. One is the parable of the Two Sons, ${ }^{3}$ with its strong complaint against His hearers, that even publicans and harlots were entering the kingdom of heaven before them. The other is the parable of the Wicked Husbandmen. ${ }^{4}$ Here the meaning is first indicated by the words, quoted from Ps. xviii. 22, about the stone which the builders had rejected being put into the position of head corner-stone. Then to place the application beyond all possibility of misunderstanding, He bursts into the solemn warning, "Therefore say I unto you, The kingdom of God shall be taken from you, and given to a nation bringing forth the fruits thereof." 5 If $u p$ to this time there had been any doubt as to His meaning among the rulers of His people, there remained room for doubt no longer. "They perceived that $\mathrm{He}$ spake of them," and they would at once have taken violent measures to silence Him but for their fear of the people.

The two parables mentioned last seem to have been followed directly by another, in which their teaching is even more distinctly conveyed. This is the parable of the Marriage Feast. ${ }^{6}$ In the refusal of the invited

1 Luke xviii. 9-14.

3 Matt. xxi. 28-32.

2 Matt. xx. 1-16.

4 Matt. xxi. 33-44.

5 There is evidently an ceho of this warning in the memorable declaration of Paul and Barmabas to the Jews of Antioch in Pisidia, "It was necessary that the worl of God should first have been spoken to you : but seeing ye put it from you, and judge yourselves unworthy of everlasting life, lo, we turn to the Gentiles" (Aets xiii. 46).

6 IIatt. xxii. 1-14. Luke xiv. 16-24 seems another version of the same. 
guests, in the judgment that they had thus shown themselves unworthy, and in the sentence that therefore none of them should taste of the feast, there is obviously a renewal of the complaint against the Jews for their rejection of the great boon which had been put within their reach. In like manner the extension of the rejected boon to the other nations of the world is announced once more, under the form of the King's command to his servants to "go out quickly into the streets and lanes of the eity, and bring in hither the poor and the maimed and the halt and the blind"; and in the second command, to "go into the highways and hedges, and compel them to come in, that the house may be filled." It was thus nothing more than a summing up of the general teaching of His life, when at the close our Lord commissioned His apostles to "go and make

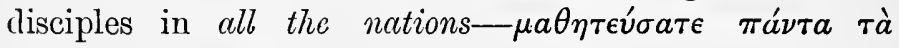
єै $\theta \nu \eta . " 1$

4. There are only two incidents in the life of Jesus which even seem to give a colour to the theory of a narrow nationalism in $\mathrm{His}$ ethical and religious sympathies. One of these arose from His journey in the most northerly region of Palestine bordering on Syria. ${ }^{2}$ There, notwithstanding His desire to avoid notice, He was sought by a woman who is described as a Canaanite or Syrophenician of Greek culture. She was thus certainly a Gentile. She sought Him to cure her daughter, who was tormented by an evil spirit. Anxious to avoid being drawn into publicity, He told her that His work was confined to "the lost sheep of the house of Israel." She persisted, however, in her appeal, and was met by a statement about the limitation of His work, reiterated in stronger form. "It is not meet to

${ }^{1}$ Matt. xxviii. 19 ; cf. Luke xxiv. 47.

2 Matt. xv. 21-28; Mark vii. 24-30. 


\section{IO SUPREME IDEAL OF CHRISTIAN LIFE}

take the children's bread, and to cast it to the dogs." To the Western mind the form of expression seems harsh; but when we take note of the thoroughly Oriental style of the whole conversation, and bear in mind the character of the speaker, it is impossible to take the phrase as other than a commonplace figure of speech which had lost all offensiveness by its familiar use. This was evidently the spirit in which it was understood by the woman herself, who, with a sort of instinctive genius quickened by motherly affection, was rcady with a happy repartee, "Yes, Lord; yet the dogs eat of the crumbs which fall from their master's table." Thereupon the action of our Lord proved that His limitation of His work was never meant as the expression of any universal or eternal law. He certainly could not have intended to elevate the national prejudice of $\mathrm{His}$ countrymen into a general principle of moral life ; for on recognising the strength of her faith $\mathrm{He}$ acceded at once to the mother's request, in the same humanitarian spirit in which He had before been moved by the faith of the Roman centurion at Capernaum.

In all this it is not difficult to read the purpose of Christ. The consciousness that $\mathrm{He}$ was "not sent but to the lost sheep of the house of Israel" was simply a recognition of the insuperable limitations which restrict all human labour. He saw that, by the laws which govern the life of man, His work would necessarily be most effective among $\mathrm{His}$ own people; but His clear insight into the import of this fact never let Him imagine that it formed an irremovable barrier against any extension of His work among other nations when the providence of God opened an opportunity for such extension. This explanation will apply to the other incident in the life of Christ, which has also been sometimes adduced as an evidence of the narrowness of 
His aim. That is His commission to the Twelve when they were first sent out as His apostles. As of the Sermon on the Mount, so of this commission, the fullest and most continuous report is given by Matthew (ch. x.). The words of special import here are the fifth and sixth verses, where our Lord repeats a phrase of His declaration to the Syrophenician woman, "Into any way of the Gentiles go not, and into any city of the Samaritans do not enter; but go ye rather to the sheep of the house of Israel that are lost." This limitation of the commission was never understood to be an immutable law. Obviously it was not so understood by the apostles themselves. As soon as it was really possible they carried the gospel beyond the limits of Judaism among Samaritans and pagans, so that, before the first generation had passed away after the death of Christ, He had won disciples in every province of the Roman Empire.

\section{$\S$ 2. Tire Moral Idfal in tire Teacinng of the APOSTLES}

With the exposition now given of the ethical teaching of Christ it is not necessary to enter with any great detail into that of the apostles. It will be sufficient to point out how clearly they grasped the ethical significance of their Master's teaching and life. For this purpose we may confine ourselves to the two principal representatives of the apostles in the New Testament, St. Paul and St. John, one dominating the earlier, another the later period of the apostolic age.

1. In the writings of Paul there are two passages of prime importance for our purpose.

(1) One of these is the thirteenth chapter of the first Epistle to the Corinthians. This chapter affords a 


\section{2 SUPREME IDEAL OF CHPISTIAN LIFE}

noble example of that tendency in the mind of the apostle to give way to a fervour of sentiment which raises his language at times into the region of poetry. The chapter, in fact, is really a lyric in prose on the pre-eminent excellence of love. ${ }^{1}$ The random division of the Received Text into chapters and verses conceals the connection in which this lyric occurs. It is well, therefore, to observe that it is preceded by an injunction to be earnest in seeking the higher graces of Christian life. Then to this injunction the apostle adds that he has a most excellent way to point out by which those graces may be attained; and following up this promise he bursts into poetic rapture over the supreme value, the indispensable necessity, of love in the Christian character.

(2) The other passage of Paul's writings occurs in Rom. xiii. 8-10. These verses follow an injunction to render to every man his due, so as to be indebted to none. Then the apostle seems to realise the necessity of explaining that there is indeed one debt of which it is impossible to be quit; and that is the debt of love. "Owe no man any thing, but to love one another: for he that loveth his fellow has completely fulfilled the law. For Thou shalt not commit adultery, Thou shalt not murder, Thou shalt not steal, Thou shalt not covet, and whatever other commandment there may be, are brought

${ }^{1}$ It is unfortunate that the Autholised Version renders árám $\eta$ by charity here as well as in some other places. The translation ajpears to have originated in Wyoliff's version, and his anthority has influenced generally subsequent English translators. But lore was already subtituted in some of the early translations, as Rogers' (1537) and the Genevan (1560), and has been very properly restored in the Revised Version of our day. It is worth while to add that $\dot{\alpha} \gamma \dot{\alpha} \pi \eta \eta$ is not a Hellenic, but only a Hellenistic word. It is never met with in any classical Greek writer, and has evidently been coined from the cognate verb. But its frequent oecurrence in the Septuagint proves that it was in common use among Hellenistic Jews. 
under one head ${ }^{1}$ in this saying, namely, 'Thou shalt love thy neighbour as thyself.' Love worketh no evil to neighbours; therefore love is the fulfilment ${ }^{2}$ of law."

Though these are the main passages of St. Paul's writings expressly dealing with the supreme principle of Christian morality, yet the whole trend of his teaching runs in the same direction. Thus he sees in the life and death of Christ the type of that love which is demanded of His followers. "Hardly," he says, "for a just man would one die; though perhaps for the good man one would even dare to die. But God proves His own love to us, because, while we were yet sinners, Christ died for us." ${ }^{3}$ Again he indicates in a significant instance how every demand of moral life must be subordinated to love. It is when he refers to the speaking of the truth. Even that obligation, with all its imperative requirements, is yet qualified by the more imperative obligation of the supreme law of morality; and some at least of the easuistical problems which bave been raised in regard to veracity would be easily solved if it were borne in mind that the truth is to be spoken in love. ${ }^{4}$

2. The Apostle John carries us back at once to the eternal foundation of the moral law in the nature of the Creator: "God is Love." ${ }^{5}$ This gives its distinetive eharacter to his Gospel, which thus becomes an historical exposition of the theme, that "God so loved the world as to give His only-begotten Son, in order that whosoever believeth on Him should not perish, but have eternal life." ${ }^{6}$ His Epistles, especially the first and most

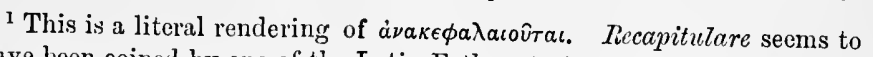
have been coined by one of the Latin Fathers to translate this verb.

${ }^{2}$ II $\lambda \eta \rho \omega \mu \alpha$ is not the act of completing, $\pi \lambda \eta \dot{\eta} \rho \omega \sigma(s$, but the result of the act, the completed thing, the complement, totality, or sum.

3 Rom. v. 7-8.

1 John iv. 8 .

${ }^{4}$ Eph. iv. 15.

${ }^{6}$ John iii. 16. 


\section{I 4 SUPREME IDEAL OF CHRISTIAN LIFE}

important, are variations of the same theme. It is on this ground he holds that no man can be said to be born of God, to know God, or to love God, unless he manifests his higher birth, his knowledge, and his love of God in the love of his fellow-men. ${ }^{1}$ There is even a startling intensity in the language which expresses his indignant refusal to recognise any divorce between the love of God and the love of man: "If a man say, I love God, while he hateth his brother, he is a liar: for he that loveth not his brother whom he hath seen, how can he love God whom he hath not seen?" 2

${ }^{1}$ It is worth while to note with attention this identification (1) of the knowledge with the love of God; (2) of both with the spiritual process described as being born of God; (3) of all three with the love of men. Compare 1 John ii. 3-4, iv. 16, 20, 21, v. 2-4.

21 Jobn iv. 20. 


\section{PAR'T II}

\section{'THE CHRISTIAN IDEAL IN ITS SUBJECTIVE ASPECT}

\section{CHAPTER I}

\section{GENERAL EXPLANATIONS}

IT has been already explained ${ }^{1}$ that virtue presents two aspects. In one it refers to the character of the virtuous man himself ; in the other, to his relations with society. The former is commonly described as personal, individual, private; the latter, as social. In the former aspect, virtue does not look beyond the subjective condition of the moral being; the latter indicates his objective relations. Briefly, therefore, the two may be distinguished as subjective and objective. In its subjective aspect virtue exhibits the moral intelligence aiming at the highest perfection of which he is capable. That means his true well-being. In this aspect, therefore, it has often been observed, virtue is identical with self-love in the most reasonable sense of the term, that is, with a love which seeks the true good of the lover himself. It is true that the term self-love is used with a considerable variation of meaning. It has, in fact, been sometimes degraded to denote the vicious principle of 
conduct which is more definitely stigmatised as sclfishness. But the difference between selfishness and self-love has long been a commonplace among moralists. This difference ought to be made clear. It is founded on an old psychological distinction which recognises a higher and a lower self in every man. The love of self, therefore, may obviously be interpreted in reference to either. It may thus be applied to characteristics which are not. only different, but opposed, inasmuch as the claims of the higher self must often come into conflict with those of the lower. It is these divergent characteristics that are distinguished in English ethical terminology by self-love and selfishness. Self-love has thus come to mean the individual's regard for his own real good. Selfishness, on the contrary, does not in propriety imply any regard for self at all, but rather a want of regard for others. The selfish man, therefore, in general is one who allows himself indulgences which imply no regard for his own interests any more than for the interests of other persons. ${ }^{1}$

In its distinctive sense self-love may thus be regarded as comprehending all personal virtue. It is that rational desire and endeavour which aim at the highest good of the individual. But as that good can be found only in a character of perfect virtue, self-love may not unfairly be regarded as including the entire sphere of morality, social as well as personal. In this fact also may be found the logical source and a plausible founda-

1 The distinction goes back to the admirable chapter on the self-lover

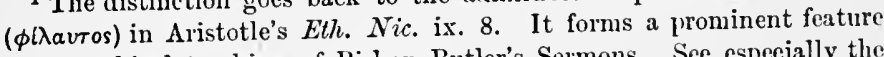
in the ethical teaching of Bishop Butler's Sermons. See especially the first and the eleventh sermons, with the preface to the whole eollection. An elaborate exposition of the distinction is given by Dugald Stewart in his Philosophy of the Aetive and Moral Powers, bk. ii. ch. i. The psyehological aspeet of the subjeet is treated with singular fulness and felicity of illustration in Professor James' P'rinciples of Psychology, vul. i. ch. x. 
tion of those theories which in technical language are described as egoistic. Unfortunately most of these theories proceed on the assumption that the chief end of life is the individual's personal pleasure. Still as different individuals draw their pleasures from different sources, the egoistic ideal admits of extremely different interpretations. These interpretations have sometimes been distinguished by reserving the name Hedonism for the theory which identifies the chief end of life with what is commonly understood by pleasure $(\dot{\eta} \delta o \nu \eta)$; while the theory which defines that end by the higher concept

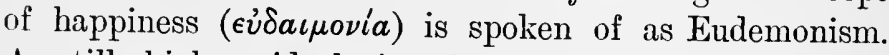
$A$ still higher ideal is that which we express by blessedness; and a theory selecting this ideal might appropriately be named Makarism, and would come nearer to Christian thought on the subject. ${ }^{1}$ In this higher concept of blessedness, Christianity evolves into clearer light the truth obscurely embodied in hedonistic and eudemonistic theories. Even that loftier Egoism, which takes personal perfection rather than personal enjoyment as the ideal of life, finds expression, as we have seen already, in the injunction, "Be ye perfect, even as your Father which is in heaven is perfect." 2

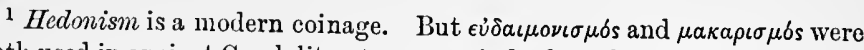
both used in ancient Greek literature, not, indced, to describe philosophical theories, but in the sense of felicitation, eongratulation, pronouncing happy or blessed. The two words, in fact, are sometimes combined like synonyms, as in Aristotle's Rhetoric, i. 9. 34, and in Cebes' Tubula, xxiii. 4. Still the adjective $\mu a ́ k \alpha \rho$ expressed an essentially higher idea than evoal $\mu \omega \nu$, the idea of a blessedness transcending the accidents of time. It was, therefore, the term properly applied to the gods, and, like the Gernan selig, to the dead. As an ethical theory, Makarism finds a brief expression in a sentenee often quoted from the chapter on "The Everlasting Yea" in Carlyle's Sartor Resartus: "There is in man a Higher than Love of Happiness; he can do withont Happiness, and instead thereof find Blessedness."

${ }^{2}$ Above, p. 24. 
The truth is that Christianity offers an adequate recognition, and therefore a scientific interpretation, of all the varied aspects of moral life. Christian Ethics is thus neither an exclusive Egoism nor an exclusive Altruism. It offers rather the true reconciliation of the two systems. This reconciliation is reached by the loftier significance to which Egoism is raised by Christian thought. It has become almost a commonplace in the history of spiritual life, that Christianity brought the infinite worth of the individual into a prominence which it had never received before. The development of this conception has been a slow process in the moral civilisation of the world. There are glimpses of an early stage of social history when the moral worth of the individual is scarcely recognised at all. That is the stage already referred to as tribal. ${ }^{1}$ One of the common features of tribal society is the fact that the individual, as an independent moral personality, is not yet clearly differentiated from his tribe. Accordingly moral responsibility and all the moral ideas it involves are associated rather with the tribe than with the individual tribesman. If a nember of one tribe kills a member of another, the guilt of the wrong is not conceived as attaching solely to the wrong-doer, even though he may be perfectly well known, and though it may be known also that no other person aided or abetted him in any way. The whole tribe must assume responsibility for the wrong, and must tender the customary atonement. The same phenomenon is witnessed where a tribe is divided into clans, and clans into families. The whole clan or the whole family is held responsible for the acts of a single member. The result is that the tribal stage of social evolution is commonly characterised by chronic wars between neighbouring tribes, by clan feuds and 1 Above, p. 41. 
family feuds that are carried down from. one generation to another. ${ }^{1}$

The moral confusions of this social condition fill many a page of primitive history, and are reflected in many of the legends of prehistoric time. Even in the Old Testament, with all its comparatively exalted morality, those moral confusions may be traced throughout a considerable part of Hebrew history. The early story of Achan's theft, involving in his punishment his whole family along with his cattle as well as his plunder, ${ }^{2}$ and from a later period the similar story of Haman, forming the chief incident in the Book of Esther, ${ }^{3}$ give sufficient illustration. But it appears that at no very late period the higher moral intelligence of the Hebrews must have begun to revolt against such a disastrous lack of moral discrimination. ${ }^{4}$ It is explicitly prohibited in the Deuteronomic revision of "the law": "The fathers shall not be put to death for the children, neither shall the children be put to death for the fathers: every man shall be put to death for his own sin." 5 It is this prohibition that is said in both of the Hebrew Histories to have guided King Amaziah in punishing only the actual murderers of his father, not their children. ${ }^{6}$ But

${ }^{1}$ INere it must suffice to refer generally to the literature dealing with tribal life for illustrations of the moral phenomena referred to ; but it may be mentioned that Dr. Parkman gives a peculiarly interesting description of the facts of tribal responsibility and of the elaborate ritual of atonement which it sonetimes demanded in the case of a murder by a Huron of a man connceted with the Jesuit mission to the Huron Indians. See his Jesuits in North America, pp. 354-360.

${ }^{2}$ Josh. vii.

${ }^{3}$ See especially ch. ix. 13-14.

4 This revolt is traced at some length in an article on "The Rise of Individualisin among the Hebrews," by Dr. J. M. P. Sunitl, in The American Journal of Theology for April 1906. By Individualism the writer means the eonsciousness of individual as distinguished from tribal responsibility.

${ }^{5}$ Deut. xxiv. 16.

"2 Kings xiv. 6 ; 2 Chrou. xxv. 4. 
the sentiment of this prohibition finds elearer and nobler expression in the teaching of the prophets. Besides a brief but pithy utterance of Jeremiah, ${ }^{1}$ the theme takes up a whole chapter in the Book of Ezekiel ; ${ }^{2}$ and within the compass of ethical and religious literature it would be difficult to find language of loftier eloquence in the enunciation of a great truth of spiritual life. Ezekiel starts from a confusion of popular thought with regard to the effects of heredity. The confusion had become such a commonplace assumption as to have found embodiment in a homely proverb which forms also the gist of Jeremiah's brief protest: "The fathers have eaten sour grapes, and the children's teeth are set on edge." The idea embodied in this proverb had received an ethical interpretation which involves an unscientific, as well as immoral and irreligious, confusion of thought. It fails to discriminate the law of moral responsibility from the law of simple sequence in nature. Men are thus made responsible for facts entailed by the law of heredity, over which they have no control. This is the confusion which the prophet denounces. Against heredity as a fact in nature he says nothing; and with the teaching of modern science we can appreciate his silence. But whatever may be the qualities which by natural causation are transmitted from parents to offspring,-and on this point the science of our time is still in the midst of an unsettled controversy,- there is no inheritance of moral values. For moral worth, for merit or guilt, every individual stands on his own footing. "The son shall not bear the iniquity of the father, neither shall the father bear the iniquity of the son"; the righteousness of the righteous and the wickedness of the wicked shall be upon each of them individually.

Jer. xxxi. 29-30.

${ }^{2}$ Ch. xviii. 
The Hebrew mind had bcen thus brought to recognise the independent moral worth of the individual personality. The Greeks also had reached a similar conception, though by a different road. The development of the conception among the Greeks was fostered by the breaking up of the old form of political organisation which had divided the people of Greece into a number of separate petty States. That primitive form of society retained necessarily some of the features of tribal life. The individual found a sphere for the larger part of his moral activity in civic duties. His moral worth, therefore, came to be estimated not so much by his excellence

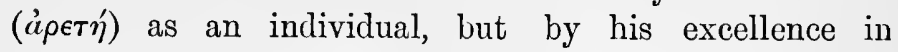
citizenship. The loss of independence, however, by the old States excluded their citizens from the political activity which had made up a large part of their moral life. In that sphere, therefore, they could no longer find that complete satisfaction which forms for every man his chief good. They had to seek that satisfaction not in the public work of citizenship, but in the private work of personal culture. Accordingly, for two or three centuries before the birth of Christ it had become a commonplace among pagan moralists - Sceptics and Epicureans as well as Stoics-that the virtuous man has an independent worth from which he can derive complete satisfaction, and that the aim of all moral training ought to be the development of this self-

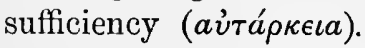

But after the most generous interpretation is allowed for the noblest utterances of Hebrew as well as of pagan thought, it remains an evident fact that no teaching of this drift approaches the sublimity of Christ's conception. His conception, however, involves no narrow Egoism or Individualism of any type; it is a recognition of what constitutes the individual's real worth, his true life or 
soul $\left(\psi v \chi \eta^{\prime}\right){ }^{1} \quad$ It is His teaching that "a man's life $\left(\zeta \omega^{\prime}\right)$ consisteth not in the abundance of the things which he possesseth." ${ }^{2}$ For Him man hinself is greater by far than all his possessions; and therefore it can profit a man nothing to gain a whole world of possessions, if he lose possession of himself, if he lose his life or soul. ${ }^{3}$ Accordingly, from this point of view the supreme end of existence sometimes takes an intensely egoistic form. It becomes simply the saving of a man's life or sonl. And therein lies a deep ethical truth. For even if the laws of the universe, in their purely natural aspect, were careful only of the type and careless of the single life, it is not so with moral laws. These deal essentially with individuals, and with individuals even when treating them in their social relations to one another. A number of individuals may indeed be united into an incorporated society for the purpose of acting as if they formed one person. But the personality, with which the society is thus endowed, is a purely artificial creation of law, a convenient fiction for enabling its members to take legal action as a whole body. The personality thus conferred on the body is merely legal, its responsibilities are confined to the formal acts demanded of it by law. It has no moral, that is, spiritual responsibilities, for it is not a real moral personality. A corporation has no soul. The moral imperative, therefore, is always addressed to a Thou. Its formula is, "Thou shalt" or "Thou shalt not."

1 The Authorised Version gives sometimes life, sometines soul, for $\psi v \times \eta^{\prime}$, and it is well to bear in mind that the two ideas are fused in the Greek term. Frequently also $\zeta \omega \dot{\eta}$ oceurs with prominence given to the higher meaning of life, as when refinerl ly aiwnos for life eternal, or simply by itself for the essence of life, with or without the definite artiele, and onee in the intensified phrase $\dot{\eta} \delta \nu \tau \omega s \zeta \omega \dot{\eta}$ (1 Tim. vi. 19). Bios also is used at times, though for a lower sense of life.

${ }^{2}$ Luke xii. 15.

3 Mark viii. 36. 
Accordingly it is the single moral life, the individual soul, that is of supreme worth in the universe. This is the sublime conception that forms perhaps the most claracteristic feature in the teaching of Christ. Under this conception the whole material universe shrinks to an infinitesimal value in itself, while the individual moral intelligence rises to a worth that is infinite in comparison. ${ }^{1}$ But this conception, when compared with the estimate of common thought, involves such a transposition of values, that it calls for some reflection in order to realise its significance. The transposition has two sides. It involves both a lowering and a heightening of value.

The depreciation involved runs counter to a general current of thought in our day. The vastness of the material universe is one of the commonplaces of scientific literature. You cannot open a popular work on astronomy which does not impress on its readers the boundless extent of the starry systems that revolve in the unfathomable abysses of space, while imagination is appalled at the enormous drafts upon the bank of time that are made by palæontology. This conception of the immeasurable extent and duration of the universe has produced a profound effect on our ideas of man and of his relation to the environment in which he lives. Such a result was in some respects a necessity of logical thinking; in other respects it is a wholly illogical inference. It is true that material things, when they are viewed simply as material, must be estimated by reference to the space and the time which they fill. But it has been said truly as well as pithily, that Time and Space are

"It may be worth noting that, in the "Song of Myself" (48), Walt Whitman gives expression to this estimate of the human soul, though in a style which contrasts with the simple language of Christ: "I say to every man or woman, Let your soul stand cool and composed before a million universes." 
no gods after all; and, I take it, the author of that saying meant that time and space do not take rank among the supreme ideals of intelligence, are not perhaps to be treated as ideals at all in any correct sense of the term. Scientific thought must, indeed, bring its ideas of time and space into harmony with observed facts; but for that purpose it is as easy to grant a million or a million of millions as a single unit. The difference between a million and a unit is a mere matter of counting, and for the expert arithmetician it becomes a vanishing fraction of thought. To a disciplined mind, it may be said without arrogance, "One day is as a thousand years, and a thousand years as one day."

There is, therefore, no reason why we should allow mere bigness to impose on our minds. The material world, with all its vast spaces and times, is in itself insignificant; that is to say, it loses all significance when it is isolated from the living interests of intelligent beings. It is hard, indeed, to understand what can be meant by a world in such isolation, a world which is neither seen, nor heard, nor touched, nor felt, nor known in any way whatever. But even if such a world could exist, it would certainly be stripped of all intelligible significance. A world like our moon, without intelligent inhabitants, even a whole system of such worlds, might occupy immeasurable regions of space and evolve through innumerable ages of time; but if it were so remote from inhabited worlds as to be incapable of affecting their destiny, it might be swept out of existence, and its annihilation would be devoid of the most trivial interest or meaning. To give it interest or meaning it would have to be appreciated by some intelligent being, it must awaken some interest in such a being, even if it be merely the interest of intelligent curiosity. Apart from such interested appreciation, a material thing or an 
event in the material world remains absolutely insignificant.

In apparent opposition to all this, besides the scientifie conception of the immensity of the material universe, there is a common line of thought in the higher literature of the world. In fact, the distinetively poetical view of nature is that which sees a wealth of meaning even in the minutest material thing. We are thus taught to

"Find tongues in trees, books in the running brooks, Sermons in stones, and good in everything." 1

There is a well-known lyric of our last great Laureate, addressed to one of those tiny objects in nature which are commonly passed without notice, almost always without any thought of their hidden meaning:

"Flower in the crannied wall,

I plnck you out of the crannies,

I hold you here, root and all, in my hand,

Little flower; but if I could understand

What you are, root and all, and all in all,

I shonld know what God and man is."

But it is extremely suggestive that the poet himself emphasises the if in these lines. In it lies the whole gist of the lyric. That little word contains the eondition of the flower's significance. The significance of the flower depends on its being understood by the poet. If there is no intelligent soul to understand what the flower is, even if there is only a soul too unintelligent to see into the meaning of the flower, then, as the Laureate's predecessor has taught us :

"A primrose by a river's brim

A yellow primrose is to him, And it is nothing more." 2

${ }^{1}$ As You Like It, Act ii. Sc. 1.

${ }^{2}$ Wordswortl's "Peter Bell," pt. i. 
The highest poetic thought and the highest scientific thought point thus to the same conclusion in regard to the world in which the problems of our moral life are to be solved. We are thus prevented from viewing that world as merely a play of material things,- of atoms, molecules, electrons, or whatever else they may be called,-pulling and pushing one another without direction from any intelligent purpose towards any intelligible end. That cannot be the last word of science in interpreting the meaning of the world. If it were, then the world would simply have no meaning at all. For intelligent beings who seek some intelligible meaning in the world which is their home, that world must be primarily and essentially the home of intelligent beings, of intelligent beings who use its material constituents as material for working out their destinies. All the triumphs of science illustrate the unceasing process by which the intelligence of man is subduing the matter of the universe to himself and forcing it to serve his purposes. Nor need we allow the immensity of the universe to hamper our thought, or prevent us from viewing it as an instrumentality for the purposes of intelligent beings. Think what is implied in the formation of those material things which we call our bodily organs, that is, the material instruments which serve the purposes of our intellectual and moral as well as our animal life. The production of an organ like the hand, the eye, the ear, the brain of man, has called into play forces that sweep through the range of our solar system, if not even of regions beyond,- - forces that have been toiling at their task, "without rest, though without haste," for millions of years.

But this conception of the material universe implies a corresponding conception of the intelligence that gives it meaning and value. And this brings us to Christ's 
point of view in regard to the worth of the intelligent soul. To Him the worth of other things is trivial in comparison. Even the gain of a whole world of other things cannot counterbalance the loss of the soul. And in point of fact, as we have seen, apart from their worth to the intelligent soul they cannot in strictness be said to have any worth at all, they are really worthless. Accordingly the loss of anything purely material is a trifling incident compared with the loss of a single soul. In all the universe there is no calamity comparable with this. In truth it may be asked whether there is any other calamity in any real sense of the term. Such a loss would defeat the very purpose for which the universe exists, the very drift of the Creator's plan. It is the intelligent moral being that indicates the significance of that plan. And consequently, as Ezekiel saw, ${ }^{1}$ it is involved in the very conception of God, that He can take no pleasure in the death of the wicked, but would rather have them turn from their wickedness and live. That is also our Lord's conception of God, though He expresses it with a tender beauty that is not found even in the language of Ezekiel. "It is not," He says, "the will of our Father in heaven that any of His little ones should perish." 2 It is on this ground that $\mathrm{He}$ sees an infinite worth even in the lowliest of our fellow-men, and utters a peculiarly solemn warning against their being treated with any unloving sentiment of scorn, as they are objects of interest and concern to the Infinite Father of all. Here again there is an inimitable pathos in the poetic beauty of the Hebrew form in which His thought finds its natural clothing: "Take heed that ye despise not one of these little ones; for I say unto you, That their angels do always behold the face of My Father which is in heaven." 3 It is in this aspect also that He makes

${ }^{1}$ Ezek. xviii. 23, 32.

2 Matt. xviii. 14.

${ }^{3}$ Matt. xviii. 10. 
His own life a revelation of the nature of God. "The Son of Man," He explains, "is come to seek and save that which was lost." 1

This conception of God, especially in His relation to the threatened loss of a soul, finds its fullest expression in the three noble parables of the lost, which have been preserved by St. Luke,- - the Lost Sheep, the Lost Piece of Silver, and the Lost Son. ${ }^{2}$ In these parables the divine attitude is described under the relations of human life. The property and the son that seem safe are left to take care of themselves in order that the whole energy of the loser may be devoted to the recovery of what is lost. So in the universe the whole "stream of tendency"-all the influences that stream from the Central Power-co-operate to avert the tragedy involved in the loss of a soul. The vis medicatrix naturo operates throughout the moral world as throughout the physical. It is as if the harmony of the universe were imperilled by the prospect of losing a soul, as if the harmony were restored when the threatened disaster is averted. And therefore the higher intelligences,

"Who range above man's mortal state,"

who see into the creative plan with larger, clearer eyes than ours, are described as thrilling with an emotion of exultant triumph over the rescue of a soul in peril: "There is joy in the presence of the angels of God over one sinner that repenteth."

Here, of course, individual personality has been viewed mainly on its practical-its moral and religious-side. But it has a speculative value as well, and this value can be clearly traced in the general trend of speculative

${ }^{1}$ Luke xix. 10.

${ }^{2}$ Luko xv. The only hint clsewhere of these parables is in Matt. xviii. $12,13$. 
thought through the deeper movements of modern Philosophy. It is this line of thought that is struck at the very beginning by Descartes finding in the reality of the self-conscious thinker the irreducible fact, beyond which his doubting analysis cannot go, as it is implied in the very reality of his doubt; and this fact became thus the irremovable foundation on which the knowledge of the doubter might be reconstructed from its ruins. This line of thought is traced with infinitely richer detail by Kant in his transcendental deduction of the categories. There his endeavour is to show that the supreme categories of all our thinking are simply the necessary forms in which we must judge of things if we think intelligently about them at all, and that these forms of judgment are necessary because they are modes of the unifying function- " the synthetic unity"-of self-consciousness. This significance of the Kantian movement, culminating in its supreme interpretation by Hegel, has been brought out with singular clearness in Dr. Hutchison Stirling's work, What is Thought? 1 The sheer logical force of this movement is strikingly indicated by the feeble resistance of Mr. J. S. Mill. His attempt to bolster up the disintegrating Empiricism of Hume by decomposing self-consciousness into "a series of feelings which can be aware of itself as a series," closes with the confession that his decomposition lands him in a "paradox," in " the inexplicable fact," "that something, which has ceased, or is not yet in existence, can still be, in a manner, present." ${ }^{2}$ But this is obviously a surrender of the very citadel of Empiricism. At the present day attention is attracted by a number of systems

${ }^{1}$ What is Thought? or the Problem of Philosophy by way of a General Conclusion so far. T. \& T. Clark, Edinburgh, 1900. See especially
ch. iv.

'Examination of Sir W. Hamilton's Philosophy, p. 213. 
under such names as Pluralism, Humanism, Personal Idealism, not to speak of Pragmatism. Through all these, amid their variations, runs the common thought of the indispensable import of unifying self-consciousness, even in the speculative interpretation of the world. Another phase of current thought draws its inspiration from the writings of the unfortunate Nietzsche, and recognises the infinite value of the individual in a novel direction by claiming for him an unrestricted play in the evolution of a new type which shall transcend the limitations of humanity. The expected Overman, ${ }^{1}$ however, is conceived as sweeping aside even the limitations of moral law. But there is no intelligible conception of moral law, except as the irreversible order of the universe in its relation to conduct; and therefore even the most Titanic will can gain strength only by calling into play the irresistible forces of that order. Consequently a being, who aims at an immoralistic ideal, does not thereby display superhuman power, but is only allowing himself in helpless impotence to be dashed against the universal order by the stress of impulses, over which he has lost control. But of such Immoralism more will have to be said in the sequel.

To return now to the relation of Egoism and Altruism, it must be obvious that in the light of the infinite worth of the soul Egoism is transfigured. Instead of being in conflict, it comes to be identical, with Altruism. The identity is, in fact, indicated by the Master Himself in that form of antithesis, of apparent paradox, by which $\mathrm{He}$ gives at times a startling emphasis to His sayings:

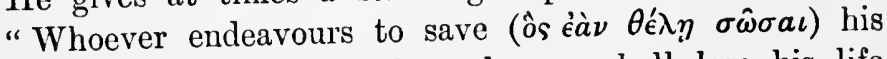
life (soul) shall lose it; but whoever shall lose his life (soul) for My sake shall find it." ${ }^{2}$ Here the conflict of

1 Why should English writers adopt the offensive hybrid, Supcrman?

2 Matt. xvi. 25. The parallels are Mark viii. 35 ; Luke ix. 25 ; John 
Egoism and Altruism disappears. The egoistic end is to be sought, ior it can be found, only in the altruistic. All this is elearly and utterly remote from the spurious Egoism by which it has often been travestied. That morbid brooding over the fate of one's soul, which degenerates at times into sheer repulsive selfishness, into hopeless, helpless melancholy, if not into suicidal madness, originates in a total misapprehension of what the saving of the soul implies. The saving of the soul means salvation from that dissolving influenee of a selfish life, which is sure to issue in a dissolution of moral energy, in what is significantly named a dissolute moral character. The call is not to aim directly at the saving of oneself, but to reach that end indireetly by forgetting-and forgetting is the opposite of getting, it is losing-oneself in the endeavour to save and to benefit others. Consequently the saving of the soul is achieved only by its emancipation from the corrupting effeets of sin, by eultivating all the virtues, altruistie and egoistic, alike. ${ }^{1}$ These constitute holiness; and holiness is, in reality as well as etymology, the wholeness or health of the soul. To the investigation of these we must now proceed.

But for this investigation it is necessary to know the nature of the moral being who is to be trained into perfect virtue or holiness. We shall begin, therefore, with a study of man's nature, at least so far as it affects his moral life.

xii. 25. In the last passage, the spiritual, that is, the purely ethical element, beeomes more pronouneed in the phrase, "He that loveth, he that hateth his life (soul)."

1 This is the teaching of the highest religious Ethies of aneient paganism also, as may be seen from the Republic of Plato, especially in the closing passage of the ninth Book. In the Tabula of Cebes this is the dominant idea of saving. The adjective $a \sigma \omega r o s, u n s a v e d$, is common in Greek literature to denote a man lost to virtue. 


\section{CHAPTER II}

THE NATURAL STATE OF MAN IN REGARD TO MORALITY

MAN is, in a sense, his own creator. As a moral being at least he is what he is by virtue of the habits which he himself forms. ${ }^{1}$ But what he is in other respects is largely determined by forces with whose operation in creating him he has had nothing to do. It is these forces that operate in the process of our birth, and in the subsequent growth which is in reality a continuation of that process. The word nature, by its etymology, describes the process of being born; and therefore the state of man, so far as it is determined by that process, is commonly and properly spoken of as his state by nature, or as his nature simply.

But this state is not identical, nor is it even in uniform harmony, with moral life. Man does not evolve into virtuous living by the sheer force of nature. Otherwise there would be no difference between moral life and natural life. There is, indeed, a naturalistic vicw of the universe, which conceives the activity of intelligent moral beings as determined by a causality essentially similar to that which determines the actions of unintclligent things. But, not to anticipate a discussion which will come more appropriately afterwards, even under extreme naturalism it is recognised that man's moral 
life is distinguished from his natural growth by being under the control of his will, however the will itself may be explained. It thus appears that in the nature of man there is a factor which does not, without voluntary direction, evolve a life of virtue, but requires for such a life to be directed, if not at times even overcome, by his will. To be directed at least, it is said, perhaps to be overcome; and this alternative points to two predominant tendencies in the interpretation of human nature, which may be traced through the whole history of scientifie, as well as of ordinary, thinking on the subject.

1. One of these contends that human nature is r intrinsically favourable to morality. On this view the natural impulses of man require merely to be guided, or rather to be left free to their own operation, in order to produce a life of perfect virtue. This view has found expression among the Hebrews in the familiar saying of the Preacher, "that God made man upright, though they have sought out many inventions." " It gives also the dominant tint to Hebrew pictures of the primitive condition of man. Not only is everything in general at the creation pronounced by the Creator to be "very good," " but man in particular is with special emphasis declared to have been created in the image of God. ${ }^{3}$ The phrase lingers in Hebrew literature passing over into the language of early Christendom. ${ }^{4}$

Among the Greeks a similar conception of human nature took a characteristic form. At an early period, as we have already seen, the problem of ethical science was by them embodied in the question whether morality

1 Eccles, vii. 29.

${ }^{2}$ Gen. i. 31.

"Gen. i. 27: "God created man in His own image, in the image of God created He him."

4 See Geu. v. 1, ix. 6 ; cf. Heb. i. 3 ; Col. iii. 10 ; Jas. iii. 9. 
has a foundation in nature or merely in the enactments of human society. ${ }^{1}$ The former of these alternatives found a peculiarly clear exposition in the central thought of Stoical Philosophy. For that system, as already explained, ${ }^{2}$ viewed all nature as the creation and exponent of Perfect Reason. Nature was thus conceived as an absolutely rational order. To the Stoic, therefore, the natural state of man was, by logical necessity, one of still uncorrupted innocence, and the moral law took the simple form of a requirement to live in accordance with nature.

In the Christian Church this view of human nature was represented by the great heretic of the fifth century, Pelagius. But, as we shall find, it continued to influence dogmatic speculation, not only in the form of what is called Semi-Pelagianism, but even in an important feature of the orthodox doctrine itself as fixed by Augustine, who was at once the main opponent of Pelagius and the main influence in formulating the doctrinal system of Christianity.

But the Stoical doctrine was destined to exert its most potent influence upon human history during the great revolutionary movements of the eighteenth century. To understand this influence, it is necessary to bear in mind that human life is impossible without the aid of fixed habits in the individual, of established laws or customs in society. But these habits and usages must be moulded anew from time to time in order to adapt them to the changes that are inevitable in the cvolution of human life. Otherwise, instead of being an aid, they become an olsstruction to the healthy growth of indiviluals as well as of communities. When life outgrows the habits and customs of an earlier age, these are apt to be felt as an irksome restraint or constraint on the human 
spirit, imposed by the artificial conventions of society; and there arises an irresistible craving to be freed from such artificial compulsion, to enjoy the unimpeded play of what is conceived to be human nature in its primitive simplicity. This craving gave a peculiar form to the old doctrine with regard to man's original state by nature. That state was conceived to be one in which man was free from all the corruptions of an artificial society. In France during the eighteenth century the coercion of the individual by social regulations had attained an extreme degree of artificiality, of irksomencss, of injustice. But the French intellect had at the same time attained an extreme degrce of clearness in its insight into the baselessness of the authority claimed for human institutions and regulations that are not demanded by the essential wants of human nature. Accordingly it was the French intellect mainly that did the revolutionary work of sapping the foundations of the artificial society of the time.

This revolutionary work found its typical repre- $v$ sentative in Rousseau. For him, especially in his earlier writings, man is by nature a being of guileless sensibility, whose natural instincts would always preserve him in uncorrupted innocence if they were never checked or thwarted by the corrupting influences of society. The great aim, therefore, of human improvement came to be conceived as an effort to throw off the unnatural tyranny by which human life is fettered, and to return to that primitive freedom in which every individual was directed by the innocent impulses of his own nature. It has been a common, though not altogether warranted, assumption of many writers, that the primeval state of human nature survives in the savage races that have persisted beyond the range of civilisation. Consequently among the writers of Rousseau's school it was a favourite 
method to illustrate that primeval state by describing the life of savage tribes. But the source from which these deseriptions are derived it is difficult to discover. The information within the reach of the writers reveals innumerable facts, before which it is hard to conceive how "the noble savage" of their pictures could ever have found shape even in the most unfettered fancy. The French had, to speak of nothing else, all Les Relations des Jesuites with their lurid pictures of life among the North American Indians. Rousseau himself, who allowed his pupil in Emile no book but Robinson Crusoe, might have found a picture of the state of nature in the cannibals from whom Crusoe rescued Friday. Defoc evidently knew what the life of savages really is, and among the philosophers of the previous century Hobbes had studied to good advantage the information on the subject that was available in his time. ${ }^{1}$ The truth obviously is that the theory of man's original nature was not drawn from any ascertained facts with regard to savage life, but that the picture of the simple unsophisticated savage was wholly woven out of an a prior $i$ theory with regard to the original nature of man. But it is astonishing to what an extent this theory has perverted the thoughts of men in regard to the problems of moral and religious, as well as political life. It frustrated some of the earliest efforts to induce Protestant Churches to undertake missionary work among the savages of heathendom, from the fear that these might have their simple virtues corrupted by the vices of civilised society. ${ }^{2}$

1 The Leviathan, p. 114 (Molesworth's edition).

2 This opposition to foreign missions found a singularly significant expression in the Church of Scotland, when the Calvinism of its creed was thrown to the winds by its dominant party in leference to the new idea with legard to the state of nature. The occasion was a dehate in the General Assembly of 1796 on a proposal to enter upon missionary work. One of the triunphant oppononts of the proposal gave iucidentally 
On the other hand, the civilised society of Europe was carried away by the desire to escape from the corruptions of its artificial civilisation by returning to the simplicity of nature; and it was this desire which, kindled into a fiery fanaticism, burst forth with volcanic fury in the European upheaval, known as the French Revolution, with which the eighteenth century closed.

But the influence of this theory about man's natural state has not passed away. It continues to find exponents here and there in a variety of forms. Thus it has affected not only social science in general, but more particularly that department of social science which deals with the industrial life of society. Under its influence the principal aim of industrial legislation came to be the emancipation of industrial enterprise as completely as possible from the artificial restrictions by which it was hampered. This aim was inspired by the conviction that, if men are left free to follow the dictates of their own nature, they will attain industrial prosperity far more unerringly than by any governmental * coercion. This application of the Rousselian theory on

a vigrorous exposition of the prevalent theories of human nature: "The untutored Indian or Otaheitan, whose daily toils produce his daily food, and who, when that is procured, basks with his family in the sun witl little reflection or care, is not without his own simple virtues. His breast can beat high with the feelings of friendship; his heart can burn with the ardour of patriotism; and although his mind have not comprehension enongh to grasp the idea of general philanthrophy, yet the houseless stranger finds a sure shelter under his hospitable, though humble, roof, and experiences that, though ignorant of the general prineiple, his soul is attuned to the feelings on which its practice must generally depend. But go and engraft on his simple manners the customs, refinements, and, may I not add, some of the vices of civilised society; and the influence of that religion, which you give as a compensation for the disadvantages attending such communications, will not refine his morals nor insure his hapliness." There is an interesting sketch of this debate in a volume of essays by Hugh Miller, from which the abovc extract is taken. 
the state of nature reached its fullest development among the economists of Britain generally, but more especially among those who are commonly grouped as $>$ forming the Manchester school. The theory also forms the scientific foundation of all intelligible Nihilism or Anarchism. For the belief that all government may with advantage be set aside must rest on the assumption that men will enter into equitable relations with one another more readily if left free to follow their own instincts, than by any man or any body of men arrogating to themselves a right to coerce the rest.

This amiable view of human nature finds expression in various forms of individual culture, which exert no little influence upon the moral life of our time, even when they are not crystallised into scientific or religious doctrines. Of these a number of types may be found among the representatives of what is indefinitely described as liberal Christianity. In illustration, Professor James quotes Theodore Parker and other leaders of the liberal movement in New England during the early part of last century. 1 These do not, of course, ignore moral defects or actual sin in men. They deny merely that human nature is cursed with an absolute negation of goodness, a positive enmity to God. One cannot but feel in their utterances the shock of a natural and not unreasonable recoil from the appalling extravagancies of the New England Calvinism, amid which they were brought up.

2. The kindly view of human nature finds its counterpart in another which runs to the opposite extreme. It contends that the natural instincts of man, so far from favouring, tend rather to thwart and baftle his efforts after moral purity. Such a view is not to be regarded as an exclusive product of Christian thought. Not only

${ }^{1}$ Varieties of Religious Experience, 1p. 81-86. 
is it found in the plaint of the Hebrew psalmist, under agony of remorse for some great wrong; declaring that he must have been "shapen in iniquity, conceived in sin." 1 The same feeling finds expression among the two great nations of pagan antiquity. Though in Greek and Roman literature there is at times a self-assertive moral pride which grates upon the sentiment of Christian humility, yet there is also to be met an extremely pathetic sense of the sinfulness that seems to have become engrained in the very nature of man. This connects itself especially in tragic poetry with the conviction that the tendency to $\sin$ is an inevitable doom inherited as a divine nemesis of ancestral guilt.

By its elevation of the moral ideal, Christianity has tended to deepen the sentiment of man's degradation. The strenuous character of St. Paul's spiritual life makes it appear to him as an unceasing battle with sin; and therefore it is not surprising that some of his descriptions of this battle seem to imply that the sin against which he fought was a foe in his own household, forming part of his very self. ${ }^{2}$ But the idea can scarcely be said to have been formulated in dogmatic shape till it was taken up by St. Augustine. His spiritual life, even more clearly than that of St. Paul, throws light on the peculiar trend of his thought on the subject. But his imperial intellect would not allow him to be content merely with a pathetic outcry of remorse. It demanded some logical explanation of the mysterious power of sinful inclinations, and it forced that explanation into its logical position as an integral part of a complete system of Theology. The Augustinian influence, as r already remarked, has been predominant throughout the whole course of theological speculation in the Church. Accordingly the state of nature, especially when cou${ }^{1}$ Ps. li. 5.

${ }^{2}$ Sce especially Rom. vi.-viii. 
trasted with what is distinguished as the state of grace, has been generally coloured by the hues of the Augustinian tradition. Those hues have been, if anything, deepened by the modern representatives of Augustinianism. In the Roman Catholic Church, Jansenists, such as even Pascal, in Protestant Churches, Calvinists of the New World as well as of the Old, have sometimes painted the depravity of man's nature in such unmitigated gloom as scarcely allowed the feeblest ray of divine light to appear in his creation; and passages could be culled from their writings which, isolated from their context, might be read as expositions of an almost atheistic pessimism. This gloom seems to have attained its uttermost darkness among the Calvinists of New England. The stern force of will, which carried them over the ocean to an unknown wilderness and sustained them in their long struggle for a bare existence on a niggardly soil, must have imparted a certain gloom to their whole intellectual and moral life; while their fiercer struggle with real savages prevented them from ever dallying with the pretty pictures of an ideal savage, which captivated the fancy of men at the safe distance of Paris or Edinburgh.

Outside the domain of Christian Theology the same conception of the state of nature has found a place in opposition to that of Rousseau. He held, as we have seen, that this state is one of simple innocence, which has only been warped into manifold forms of corruption by the artificial tyranny of social regulations. On the other hand, with a far truer, if still inadequate analysis, Hobbes saw that, apart from social restraints and stimulants, moral life could find no soil on which to grow. Men, secking the gratification of their natural inclinations, would inevitably come into conflict with one another whenever they became competitors for the same 
means of gratification, so that the state of nature would be one of incessant war, in which every man's hand would be turned against his fellow. ${ }^{1}$

On reviewing these apparently antagonistic theories of human nature with a critical eye, it does not require any great insight to discover that in reality they are not mutually exclusive. The supporters of each may indeed be under the impression that their theory is incompatible with the other; but the theory becomes false by being viewed in this light. Each theory, in fact, is true merely in so far as it is a complement of the other. Each obtrudes one phase of the complex nature of man so prominently as to exclude another phase which is equally real. Of these phases neither, when taken by itself, is more than a fictitious abstraction of thought. Such abstraction is, of course, a legitimate process; it is not only useful, but even indispensable, in science. Only by thus isolating a phenomenon from its concrete entanglements can it be clearly apprehended in its own distinctive nature. There may be something gained for the science of human nature by trying to conceive what man would be if he were a purely rational being, made in the image of God, untainted by any corruption from hereditary faults or from the contamination of an artificial society. On the other hand, there might be a similar gain in trying to conceive what man would be if he were absolutely estranged from God or from the civilising influences of social order. But in either case the gain is subject to the condition that the conception attempted shall be recognised as a mere abstraction, and the gain is converted into a very decided loss for scientific thinking when either conception is taken to represent the full concrete reality of man's condition by nature.

1 The Leviathan, pt. i. ch. xiii., with the corresponding chapter in De Cive and its English version. 
The consciousness of this fact comes out more or less clearly in the history of the rival theorics. Even Stoicism had already recognised the inevitable qualification of its own view. While holding that all nature is the creation and embodiment of Perfect Reason, the Stoics were from the first obliged to take account of a fact which they found it difficult to force into any rational system. Previous thinkers had separated in the mind of man between his reason and his emotional impulses by dubbing the latter with the abstract denomination of

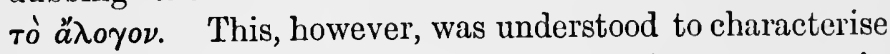
emotion simply as something different from reason, in other words, as a non-rational element in human nature. But by the Stoic emotion was conceived as positively irrational. He made it a perversion of reason, a perversion that goes against reason's very nature, and is therefore unnatural as well as irrational. Accordingly for him emotion was not, what it had been for Plato and Aristotle, an element of human nature which, though not in itself rational, is to be directed by reason and thereby elevated into the rational or moral life. It was a foe with which reason could never come to terms, a foe to be completely annihilated as incompatible with morality, that is, with reasonable life in any form. But emotion remains a fact of human nature, whether reason come to terms with it or not. The virtue, therefore, which demands its total suppression, came to be regarded as a rare privilege reserved for an extremely select aristocracy of the wise, while the moral condition of mankind in the mass was described in pictures of gloom which parallel some of the darkest in the literature of Calvinism.

With regard to Rousseau's theory on the state of nature, it need only be said that, even if it he not selfcontradictory, it is inconsistent with any theory whatever of morality. Moral science must assume that a right 


\section{MAN IN REGARD TO MORALITY}

action is a reasonable action, and a wrong action one that is unreasonable. But to get at the primitive innocence which he imagines to have been characteristic of the state of nature, Rousseau finds himself obliged to eliminate the whole of the culture which has been attained by the use of reason. This at least is the teaching of his two early Discourses on the corruption of men by science and art, and on the origin of inequality among men. Human nature is thus reduced to an inconceivable abstraction of mere sensibility, not only uncorrupted, but wholly untutored by any kind of rational training. The innocence, which is thus ascribed to man's primitive nature, does not really differ from that innocence which, in poetical descriptions of rural scenes, is often attributed to the lower animals, - to herbivora in general as well as the young of all tribes. ${ }^{1}$ Nor does Rousseau conceal the inference from his theory, that moral or rational life must be abandoned in favour of a non-rational or purely animal existence. This may be illustrated by a single, but significant, example. The

${ }^{1}$ In some moods Walt Whitman seems to come near this attitude of Rousscau, as in the "Song of Myself," 32 :

"I could turn and live with animals, they are so placid and self-contained ;

I staud and look at them long and long;

They do not sweat and whine about their condition;

They do not lie awake in the dark and weep for their sins;

They do not make sick discussing their duty to Gol.""

$\Lambda$ similar, if not exactly identical, mood may be met with in saintly mystics; and as James has remarked (Varieties of Religious Experience, p. 396), Whitman had a saving dash of the mystical temperament. In faet not only religions, but all emotion tends to find gratifieation in idealising animal life, in dallying with its own idealisations, even identifying itself with them, and stimulating sympathetically, or at least envying, their idealised enjoyments. Animal worship is not an inconıprehensible phase of religion. On this cult see the singularly subtle, but genial, remarks of Hegel in his Philosophie der Religion, vol. i. pp. 235-237. 
only relation of the sexes in harmony with primitive innocence becomes one that is governed solely by the impulses of sexual sensibility, unfettered by any matrimonial legislation such as reason might dictate. The innocence of such a state of nature might come alarmingly near the original sin of the Augustinian or Calvinist. No wonder that even Nietzsche characterised Rousseau as advocating a return to nature " in impuris naturalibus." 1

But if the abstract conception of man's natural state as one of simple innocence breaks down before the force , of concrete facts, a similar fate attends the opposite conception. This is clearly recognised in those systems of Theology which follow the Augustinian type. In all these the original depravity of human nature is regarded as original only in a very subordinate sense. It forms no integral factor of man's nature as it came direct from the Creative Will, but is the result of an historical accident described as his fall. On the other hand, the primeval condition of man before his fall is irradiated with a glory far surpassing not only the insipid animalism of Rousseau's ideal, but even the nobler intellectualism which characterised the ideal of the Stoics. In spite of the severe Calvinistic Puritanism which formed his social and spiritual environment, Milton has given, in his great religious epic, a picture of the ideal innocence of man's lost paradise illuminated with such an idyllic charm as seems never to have been even approached in the literature of Roussean's school.

It is due to Hobbes to add that his teaching on this subject is in general very inadequately represented. It is quite true that he demolished in advance the doctrine of Rousseau. His description of the state of nature is not, like Rousseau's, merely a fanciful picture. It is a

1 Götzendämmerung in Nietzsche's Werke, vol. viii. p. 117. There is a longer onslaught on Rousseau at pp. 161-162. See also Pp. 121 and 295. 
product of scientific analysis, so far as it goes; and as we have just seen, ${ }^{1}$ it is fortified by a truer interpretation of the facts of savage life. But, after all, his conception of human nature is really nobler than that of Rousseau. For reason is not regarded by him as an artificial excrescence which perverts the unsophisticated sinplicity of nature. On the contrary, it is an integral factor, and the authoritative factor, in the nature of man. Accordingly Natural Law became for him that code of regulations which reason dictates as indis- pensable for social intercourse, for the well-being of individuals in their relations with one another. ${ }^{2}$ However different, therefore, the Philosophy of Hobbes may be in other respects from that of the Stoies, the two are akin in their conception of the Law of Nature. Thus also Hobbes' description of the state of Nature finds a very important complement in his account of Natural Law, just as the Augustinian doctrine of man's natural state since the fall is modified by the complementary doctrine of his natural state before.

Another fact illustrates the abstract and fictitious character of the state of nature pictured in all these theories. That state of nature is admitted to be no historical reality. The ideal of primitive innocence is always relegated to the forgotten childhood of humanity -a golden age, a lost paradise, which retires before historical inquiry into the blank region of a prehistoric period. In like manner, the opposite view can only assume that it is represented by some unknown, if not inconceivable, type of savage. Even for the latest scientific research into the evolution of man from the mere animal there remains here a missing link.

1 Above, p. 136.

2 The Leviathan, pt. i. chs. 14 and 15, with the corresponding chapters in De Cive and its English version. 
It was necessary thus to notice these theories of man's state by nature on account of their intimate connection with our special study. They have played no unimportant part in discussions on moral and political problems, and not least on the problems of Christian Ethics. The science of Christian living has often been obscured by doubtful theories of man's natural state. It is, therefore, of the highest importance to disentangle fact from the theory or dogma by which it is explained to some minds. Facts cannot be cvaded, but, if ignored, continue their operation all the same. There are obviously certain facts in our nature which must be reckoned with in the training of Christian life. What are these?

(1) There are impulses in human nature which, though > not in themselves inimical to virtue, are apt to become so if not controlled by moral purpose. There may be a difficulty in determining whether a particular impulse is inborn or acquired, whether it is an instinct or a common habit formed at a period long before any to which memory extends. Questions of this drift have been a favourite field of psychological controversy. Something has been said already on the relation of instinct and habit, and the former was shown to depend on the latter for its influence. ${ }^{1}$ Even, therefore, if a particular impulse is instinctive, it preserves and it gains or loses its force by habitual indulgence or restraint. But it is sufficient to recognise the actual existence of incliuations which nust be controlled by the Christian spirit in order to attain a truly Christian life. If that fact is recognised, it is not necessary to adopt any particular theory regarding the origin of the inclinations in question.

Of course, science must not be fettered in the investigation of these phenomena; and its work is likely to be fettered all the less, the more clearly men come 
to realise that the interests of their higher life are in no way imperilled by the possible results of investigation. At the present time there is a dominant tendency of scientific thought on the question at issue. That side, at least, of human nature, which has been described as its original depravity, will by scientific biologists almost universally be regarded as a survival of phenomena belonging to lower forms of animal life which have not yet been eliminated in the process of evolution. It is not so easy to determine what must be the trend of scientific thought in regard to the facts described as the primitive innocence of human nature. On this point materialistic and idealistic theories of evolution may be hopelessly irreconcilable. But Christian life demands merely a recognition of the facts, leaving scientific inquiry free to construct its own theories for their explandion. For the Christian the facts have received appropriate recognition from the highest authority"Except ye become as little children, ye shall in no wise enter into the kingdom of heaven." 1

But scientific speculation is not alone in its claim on this region of thought. The imagination of the poet also has its rights. Nor is it without a fruitful function, even in the interests of the highest scientific thought. For the poetic mind is not so liable to be carried away by abstractions as the scientific. It is ready to see facts, not in any fictitious isolation such as is created by scientific analysis, but rather in their real connection with the concrete whole to which they belong. But the very aim of the highest science also, the aim of philosophic thought, is to reconstruct into their permanent connections the facts which have been temporarily isolated for separate study in the analyses of the special sciences. Consequently poetic imagination

${ }^{1}$ Matt. xviii. 3. 
and seientifie thought often pass over into one another; and on the nature of man in particular, with its pitiful degradations on one hand, with its lofty aspirations and possibilities on the other, theories have been mooted which may be elassed either with the splendid faneies of the poet or with the daring hypotheses of the philosopher. Such is the conception of man's mental life extending not only in the future, but also in the past, beyond the life of his body. This eonception is not merely a conjecture of speculative thought; it plays an active part in the religious life of the world, and precisely in that region of religious life with which it is here associated. In any description of Buddhist communities one is apt to be surprised at the common tendency of the people to view all the evil which they suffer in this life as a retributive consequence of evil which they have done in a previous state. The idea has never exerted the same influence in the life of Western nations, though it has found a place in their speculative systems. Among the ancient Greeks it was represented by the Pythagoreans, by Empedocles and by Plato. Among modern theologians, Julius Müller has adopted it in his work, On the Christian Doctrine of Sin, to explain the original depravity of human nature; and it finds an influential ehampionship in the philosophical system which, under the name of Pluralism, attracts attention in our day. ${ }^{1}$

The truth is that the general idea of pre-existence admits of considerable modification as interpreted both by poetic and by scientific minds. It may even degenerate at times into crude pietures of a pre-natal state, coloured in extravagantly faneiful fashion with the hues of earthly

${ }^{1} \mathrm{~A}$ brief critique of this system, especially in its bearing on preexistence, will be found in Dr. Rashdall's Theory of Good and Evil (1907), vol. ii. pp. 345-347. 
existence, while in another direction it may evaporate into the vague, though important, psychological commonplace, that the mind of man admits of no adequate explanation as evolving from his bodily organism. But the idea that the individual self in a very real manner transcends the limits of time in the past as well as in the future, transcends the limits of time altogether,-that has been for many great philosophic and poetic thinkers no pretty conceit with which imagination may dally in an idle hour, but an earnest endeavour to attain a rational comprehension of the real nature of man. Nowhere, perhaps, has the idea found nobler expression than in Wordsworth's great Ode, "On the Intimations of Immortality from Recollections of Childhood." Not inappropriately it is the divine side of man's nature that the poem brings into special prominence, but the lower cravings and their origin are not ignored. Perhaps, indeed, the explanation of these comes nearer the truth in its concrete fulness than most of the dogmas of a narrow Theology or of an equally narrow science.

"Our birth is but a sleep and a forgetting:

The soul that rises with us, our life's star,

Hath had elsewhere its setting,

And cometh from afar;

Not in entire forgetfulness,

And not in utter nakedness,

But trailing clouds of glory do we come

From God, who is our home:

Heaven lies about us in our infancy!

Shades of the prison-house begin to close

Upon the growing boy,

But he beholds the light, and whence it flows,-

He sees it in his joy ;

The youth, who daily farther from the east

MIust travel, still is nature's priest,

And by the vision splendid

Is on his way attended;

At length the man perceives it die away

And fade into the light of common day. 
Earth fills her lap with pleasures of her own; Yearnings she hath in her own natural kind, Ancl, even with something of a mother's mind, And no unworthy aim, The homely nurse doth all she can To make her foster-child, her inmate man, Forget the glories he hath known, And that imperial palace whence he eame."

(2) While it is necessary to recognise the fact that there are in human nature impulses which may become inimical to moral well-being, it is equally important to bear in mind that the real significance of this general statement is to be found in the particular facts which it comprehends. The impulses, which have to be reckoned with in moral training, are not the same in all men; they vary vastly in different individuals. Accordingly it becomes a demand of moral prudence that every individual should carefully examine the peculiarities of his natural temperament in special view of their influence on his moral life. It then becomes a further requirement that his conduct should be governed by a constant caution against the moral dangers to which his self-examination proves that he is peculiarly exposed. The race of life demands of the successful runner that he shall disencumber himself not only in general from all unnecessary weight, but mole particularly from any sin by which he is easily beset. ${ }^{1}$ There may be impulses which, from heredity or other causes, have acquired a natural tendency to excess. Against such it will be indispensable to maintain an unremitting guard. Some even it may be an imperative duty to repress altogether, so far as nature will allow, when, like the morbid craving for alcohol, they will not take even a moderate indulgence without assuming an uncontrollable tyranny over the will. Other inpulses, 
again, such as sympathy, which are favourable or even essential to active virtue, may from various causes be deficient in natural vigour, responding but feebly and sluggishly to their natural stimulants. These it will often be necessary to cultivate with tender care by seeking opportunities for their exercise more frequently than the exigencies of life ordinarily require.

(3) But whatever be the faults of natural temperament, these can never with propriety be described as in themselves sinful. Original sin, interpreted in its strict sense, $\checkmark$ is a contradiction in terms, is, therefore, as meaningless and unthinkable as a square circle. For sin is the personal act of a moral being, and cannot be attributed to any person at the origin of his existence before he has done any moral action. Even if sin be understood in the sense of sinfulness as denoting chronic inclinations rather than any single action, still in so far as these are original or inborn, they cannot be called sinful in any accurate use of the term, they become sinful only when they are sinfully indulged. Till then they are simply products of natural causation, and, like other phenomena viewed as purely natural products, they are absolutely non-moral.

This distinction between moral and merely natural phenomena it is all the more necessary to enforce, because there is a stage of moral culture at which the two are frequently confounded. In the previous chapter it was pointed out that in primitive tribal society the individual has not risen into clear moral independence, his personal responsibility not being distinctly separated from the joint responsibility of his tribe or clan or family. As a result of this, individuals are often involved in the penalty of actions with which they had personally nothing to do. Apparently there has been at times, within the domain of Christian Dogmatics, a tendency to extend this moral confusion of tribal society 
to the whole community of mankind. The entire race of men are spoken of as responsible for an offence of their primeval ancestor. This is not the place to discuss the dogma in question, or to analyse the interpretations which it may be understood to bear. It may be fairly taken as at least a protest against an unscientific > Individualism which would treat each human being as holding an isolated independence on his fellow-men. It thus enforces the familiar fact that no man liveth to himself, that for good or evil he inevitably affects the lives of others. So far as the dogma in question embodies this truth, it is only fortified by the strong trend of scientific thought in regard to heredity and the general solidarity of mankind. But, as already pointed out, ${ }^{1}$ there is no inheritance or eommunication of moral values. The influence which another excrts upon me is by itself an action for which he alone can be called to account. My accountability begins only with my reaction under his influence, with my yielding or resisting. Whether or not the great theologians, with whose names the dogma in question is assoeiated, meant by it more than this mutual reaction of moral beings, they seem always to distinguish between imputed and real guilt, as in theories of atonement also they distinguish between imputed and real merit. In any case, surely at the present day no reader, who is likely to be attracted to the Rubaiyat of Omar Khayyam, can feel that any phase of thought with which he is in sympathy is touched by the verse:

"O Thou, who man of baser earth didst make, And e'en with Paradise devise the snake,

For all the sin wherewith the face of man

Is blackened, man's forgiveness give-and take." 2

1 Above, p. 120.

2 It seareely required the assurance of Professor Cowell, Fitzgerald's teacher in Persian, to know that the allusion to the Hebrew story of 


\section{MAN IN REGARD TO MORALITY}

(4) The same fact holds with regard to all the impulses with which man is endowed by heredity or any other natural cause. It is not the natural endowment, but his voluntary control over it, that gives him a moral $r$ character. Consequently, whatever explanation may be given of man's natural impulses, in order to the very possibility of moral life it is essential that he should not be their helpless slave. On this point it is unnecessary to enlarge again. It has been already ${ }^{1}$ poiuted out that, all through animal life, congenital instincts are of influence only in so far as they are kept in exercise. They may never come into play at all, or they may die out after a time from the absence of their natural stimulants, or they may be completely supplanted by the formation of counteractive liabits. If this is the case with the nature of the mere animal, it is preposterous to suppose that man's moral life is fixed beforehand unalterably by the nature which he receives at birth, and that he cannot direct it to any extent by his own voluntary efforts.

The problem now before us is to trace this direction, that is, the process by which man's nature is uplifted into the control of his will till it attains the ideal of Christian life.

Paradise with the serpent and the fall of man, not to speak of the later theological dogmas by which it was interpreted, could not have anything corresponding to it in the original Persian. Professor Cowell thought that Fitzgerald may have been misled by wrong translation of a quatrain which runs in the same form, but with profoundly different meaning:

"O Thou who knowest the secret of every one's mind,

Who graspest every one's hand in the hour of weakness,

$O$ God, give me repentance and accept my excuses,

Thou who givest repentance and acceptest the excuses of every one."

Cowell says lie wrote to Fitzgerald about this, "but he never cared to alter it." It does not seem clear, however, that Fitzgerald was here translating at all ; he may have created his quatrain.

${ }^{1}$ Above, pp. 33, 34. 


\section{CHAPTER III}

\section{THE BEGINNING OF CHRISTIAN LIFE}

Beginnings form the most intractable problem for scientific thought. The problem faces us in its most complicated form when we endeavour to account for the beginning of Christian life. The origin of matter and motion, the origin of organisation in general, the origin of new organic forms, - these are questions which have long baffled scientific thought, and still wait a satisfactory answer. But the interval between the highest form of material organisation and the lowest form of conscious life is a chasm which no intellectual engineering has been able to bridge by the common eategories of science; and this chasm is widest at the point where the finite spirit of man enters into conscious communion with the Infinite Spirit of the universe. Perhaps the utmost we ean do is simply to study the facts connected with the first appearance of Christian life in individual experience. That, at least, must be our first task.

For practical purposes the early weeks of human life form a period of mere animality. The fact is recognised in common thought and language, that a considerable time elapses before a child comes to the use of reason; and he is therefore treated all this time as incapable of that rational control which is understood by will in the proper sense of the term. Prior to the attainment of this control, human life is governed by impulses which 


\section{THE BEGINNING OF CHRISTIAN LIFE I 55}

are purely natural, that is, non-rational, non-moral. From the very nature of the case these impulses must, by repeated indulgence, acquire in childhood the force of habits. As soon, therefore, as moral consciousness is awakened, that is, as soon as reason is directed to the government of conduct, men find that, by the force of their emotional impulses, they are being frequently drawn into the performance of actions that are unreasonable, wrong.

But a wrong action may be viewed in a variety of lights. In its most extrinsic aspect it may be a crime, that is, an act violating some law of the State in which the wrong-doer resides. As a vice it is conceived most prominently as corrupting his own moral character. When it inflicts injury upon another, it is spoken of properly as a wrong. But there is a deeper import still in such an action. It strikes at the cternal order of the universe, in which the will of the Maker is revealed. It is a $\sin$. This view of evil is by no means exclusively Christian. It gives a solemn tone to the moral sentiment of all races of men. It is, however, a view that is absolutely indispensable in Christian life. No man begins a moral development that is distinctively Christian till a consciousness of the evil he has done takes shape in the confession, "Father, I have sinned against heaven and in Thy sight." 1 Accordingly the first awakening of earnest thought on personal religion is commonly associated with an awakening to the fact of personal sin; and we are prepared for the conclusion, to which a scientific study of religious life has led, that in conversion the sense of $\sin$ is the central fact.

${ }^{1}$ Luke xv. 18 and 21. Compare the pathetic plaint of Ps. li. 4, "Against Thee, Thee only, have I sinned, and done this evil in Thy sight." See Starbuck's Psychology of Religion, 1p. 58, 64, 67 (2nd edition). 


\section{$\S 1$. SiN}

Here, then, is a fact which faces us at the outset in our endeavour to understand the beginning of Christian life. We must not, indeed, complicate our study by entering into problems that are only of speculative interest. The ethical interest is practical. What it demands here is such an intellectual attitude towards sin as must be assumed in order to the possibility of moral life. Now there are certain views of sin which, if adopted for the regulation of conduct, would tend to weaken or paralyse all effort to direct life towards an ideal. Such are the views which are involved in all forms of absolute Naturalism. Under this name may be included all those systems of thought which look upon all events, including the actions of moral agents, as simply natural effects resulting from natural causes. This would describe Materialism in every shape. It would also characterise many systems of pantheistic drift as holding all events, good and evil alike, to be necessary emanations of an Infinite Substance or Force. The description would also apply to an extreme Predestinarianism which denies independent activity to all finite beings.

In historical fairness it ought to be observed that this inference has been in general opposed by the schools which have been most strenuous in asserting the doctrine of predestination. And that with philosophical justification. For predestination, as the act of Infinite Intelligence, cannot be construed after the analogy of a natural cause entering into the stream of natural events, itself determined by antecedent causes, while it determines its consequent effects. Accordingly in practical life the influence of the doctrine has been far from that of a paralysing Fatalism. In Christian history the sects 
which have followed most closely the Augustinian tradition-the Jansenists of the Roman Church and the Calvinists of Protestantism-furnish a long array of heroic per'sonalities, displaying that force of will which can be the fruit only of strong practical faith in personal freedom. Calvinism is usually regarded as having found an extremely explicit expression in the Westminster Confession of Faith; yet it would be difficult to find in the symbolic books of Christendom a more explicit assertion of moral freedom than is given in this symbol. In chapter iii., which treats of God's Eternal Decree, while it is stated that "God from all eternity did, by the most wise and holy counsel of His own will, freely and unchangeably ordain whatsoever comes to pass," this statement is immediately qualified by the distinct condition, "Yet so as thereby neither is God the author of sin, nor is violence offered to the will of the creatures, nor is the liberty or contingency of second causes taken away, but rather established." 1

For Christian Ethics, then, there are two aspects of sin which must be regarded as essential. One may bo

${ }^{1}$ It is worth adding in a note that the Scottish School of Philosophy, $>$ which was always intimately associated with the Calvinistic Church of Scotland, was also prominent in defending the Freedom of the Will against the doctrine of Philosophical Necessity. In the early part of last century, when (as I believe) the writings of Jonathan Edwards came to be known in Britain, there arose among Scottish divines a brief tendency to dally with the latter doctrine as affording apparently a philosophical foundation for Calvinism. But the greatest representative of the national school, Sir W. Hamilton, uttered a vigorous protest "against such a view of Calvin's doctrine and of Scottish orthodoxy . . . as, to speak mildly, not only false in philosophy, but heretical, ignorant, suicidal in theology" (Discussions, p. 628). And, not withont truth, Mr. J. S. Mill has said of Hamilton, that "the doctrine of Free Will was indeed so fundamental with him that it may be regarded as the central idea of his system-the determining canse of most of his philosophical opinions" (Examination of Sir William Hamilton's Philosophy, p. 488, 1st edition). 
spoken of as the divine aspect, the other as the human. The former is completely blurred in an un-Christian confusion of thought if God is regarded as in any sense the author of sin. Christian life becomes simply impossible if a man allows himself to be trieked, by any ingenuity of dialectic, into the illusion that in doing a sinful act he may be doing the will of God. There can be no Christian sense of sin unless the sinner realises that, in so far as his action is sinful, it is wholly antagonistic to God's will -in other words, that he is willing to do what God wills that he shall not do. This does not

- deny that the will of God is absolutely without influence on the will of man. The will of one intelligent being may always influence the will of another. But the mutual influence of intelligent beings is not to be identified with that reciprocity of causation which binds unintelligent phenomena in the rigid connections of natural law. It is difficult to understand why it should , be regarded as an eminently scientific habit of thought to confound the two modes of interaction. But even when the two are identified, the difficulty of sin, of evil action, does not disappear. There is then forced upon us the problem of explaining how beings that come into existence by virtue of the cosmie order are yet determined by that order to perform actions which are painful and destructive to themselves or to others or to both, and which, therefore, violate in some way the very conditions of existence which form the order of the universe. On the other hand, to the religious mind the universe is not merely a play of forees whose interaction is absolutely predetermined through all time; it is essentially a kingdom of intelligenees, who do indeed exert a manifold influence on one another, but cannot coerce one another in the fashion of a natural force.

This brings us to the other, the human, aspect of sin. 
To Christian thought, while $\sin$ is viewed as wholly opposed to the will of God, it is also viewed as proceeding wholly from the will of man. This does not inply that a moral action, whether right or wrong, is without any natural phase, is wholly isolated from the course of nature. Such an action, even if conceivable, would be equally futile with that of a physical force playing in vacuo. The very function of intelligent activity, and therefore of morality, is to direct the forces of nature so as to make them subservient to the ends of intelligence. But such direction is possible only by working in harmony with the laws which govern those forces; and the obligation, which these laws impose, is to the religious mind all the more imperative that they are regarded as manifesting the will of God, so that a deliberate violation of them becomes a transgression of that will-in other words, a sin. A moral action has thus a connection with the causes and effects which make up the course of nature. In some of its phases it may often be explained, and explained very largely, by such natural causes as heredity and environment. But in so far as it admits of explanation by such causes, it is simply an event that has been brought about in the ordinary course of nature, it is not a distinctively moral action. An action becomes moral only when it ceases to be explained as a purely natural event, only when it becomes an independent product of volition.

From this it follows that a volition must not itself be conceived as merely an effect of natural causes. Will is what distinguishes the action of conscious intelligences $r$ from the action of unconscious unintelligent things. It is thus one of the phases of conscious life, and the problem of its nature is but a particular phase of a general problem . which all consciousness involves. That problem may be cxpressed in the question whether the phenomena of conscious life can be brought into the same causal correla- 
tion with the phenomena of the physical world as that in which these stand to one another. Now, for the purposes of scientific thought, the causal connection of phenomena finds its meaning and value as a relation of identity amid all differences between antecedents and consequents; and this identity comes all the more thoroughly under the control of science the more exactly it becomes measurable in units of quantity. If, then, volition and the con, comitant phenomena of conscious life are correlated with the phenomena of matter in quantities that are rigidly fixed by the order of nature, moral responsibility and moral desert would have to be treated as mere figments if they were understood to imply that an agent with conscious intelligence is at the moment of action free to act in any other way than that in which he acts in reality, or that he can be called to account for his action in any other sense than that in which an unintelligent thing is accountable for what happens to it. But if there is one fact to which the researches of Physiological Psychology point more clearly than another, it is to the futility of all attempts to bring the phenomena of con- $>$ scious life into any quantitative commensuration with those of the material world.

Morality, then, as the highest aspect of an intelligent being's life, does not admit of any interpretation which views it as a product of natural causation. "Know," says Matthew Arnold,

"Know, man hath all which Nature hath, and more; And in that more lie all his hopes of good." 1

In another poem Arnold describes Nature, awed by the mystery of a law transcending her own, as realising that morality originates in an ethereal sphere beyond her limitations.

'From the sonnet, "In Harmony with Nature." 


\section{THE BEGINNING OF CHRISTIAN LIFE I6I}

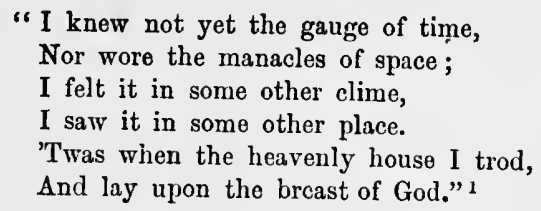

In the genuine claims of science or of philosophic or poetic thought there is thus no obstacle to the view of sin which Christian Ethics demands,- the view that, after making all allowance for the natural influences by which the sinner is tempted, these do not account for his action altogether, but that he himself must render the account as being in a very real sense the author of his action. It has likewise been explained that no objection to this view can be drawn from the relation of the finite will to the Infinite. In the finite will itself there is a certain infinitude; it forms one phase of the divine. image in which man is made. That is indeed an awful grandeur with which he is invested as a moral being; he cannot be coerced against his will even by the Infinite. ${ }^{2}$ This fact affords a speculative kernel for the appalling doctrine of eternal punishment, the purport of which could be indicated more clearly if it were described as asserting the power of sinning for ever. For if the will is viewed merely in the abstract, that is, in abstraction from the concrete conditions under which alone it can be realised, it is not impossible to conceive it maintaining for ever an attitude of hostility to the will of God. This conception, in fact, furnishes the germ from which have been developed the most stupendous creations of tragic literature. Among the ancient Greeks it found embodiment in the myth of Prometheus

1 From the Lyric entitled "Morality."

${ }^{2}$ Is it this infinitude of will to which Novalis points in one of his enigmatical fragments: "What I will, that I can. With man nothing is impossible"? (Schriften, vol. ii. p. 191). 
with his Titanic will defying the supreme ruler of gods and men. It is the secret of the fearful spell wielded over Milton's readers by the real hero of his great poem,

"Who durst defy the Omnipotent to arms."

Of the numerous other attempts in modern literature to portray the Spirit of Evil the tragic interest is also to be found in the limitless daring of will displayed.

It is characteristic of the genius of Shakespeare that he has never made the attempt to portray evil will in the abstract, but only in the concrete conditions under which it is ordinarily manifested in human life. His Iago is perhaps as near an approach to a purely evil spirit as is easily conceivable within the limits of human nature. But Iago is no claimant for the unenviable distinction of embodying evil will in its abstract generality. He embodies an evil will under such social conditions as restrict the life of man everywhere. Nor is it at all likely that Shakespeare would ever have attempted the impossible task of exhibiting a superhuman force of. will in the indulgence of a nature so powerfully impulsive as to be uncontrollable by reason within the restraints of moral law. Such a glorification of sheer power, of the Titanic and Satanic ideals of tragic literature, has reached its culmination $>$ in the Overman of Nietzsche's rhapsodies, and its travesty in his followers among the playwrights of our day. Their superhuman ideal of character is not, like Aristotle's, a sublimity of virtue so far above the common attainments of humanity that it may well be spoken of as heroic or godlike. ${ }^{1}$ It is rather a will which asserts its fancied force in an activity that shakes off the encumbrances of morality to enjoy the licence of a region beyond the difference of good and evil, "Jenseits

${ }^{1}$ Eth. Nic. vii. 1. 1-2 


\section{THE BEGINNING OF CHRISTIAN LIFE I 63}

von Gut und Böse." This ideal of Immoralism has attracted the genius of Shakespeare also, but with true psychological analysis and clear artistic insight he saw that it could with propriety be treated only as a theme for comedy. In the extravaganza of Sir John Falstaff he has created a butt of fun that bears down all barriers of serious sentiment, and opens the sluices of goodhumoured mirth to revel over the preposterous absurdity of an intelligent being who rollicks through life in ludicrous insouciance about the elementary requirements of rational conduct. Falstaff is the logical Overmanor shall we call him rather the Underman?-of immoralistic fancy.

\section{$\S 2$. Repentance or Conversion}

The drift of the previous section has been to show that man is himself responsible for his sin, so far as it. is sin. This implies that he is also responsible for its amendment. The obligation to amendment is involved in responsibility for the $\sin$ to be amended. Now the first step towards amendment is repentance for the sin done. The great historical movement of Christianity began with a call to repentance, not only by Christ Himself, but by His forerunner also $;^{1}$ and in the life of the individual, Christianity must begin as it began in the history of the world.

The truth is that moralists in general have recognised the necessity of repentance in relation to the sins of the past as an indispensable first step in any moral reform. ${ }^{2}$

${ }^{1}$ While all the evangelists, John as well as the others, give this significant place to the preaching of John the Baptist, Mark explicitly describes it as "the beginning of the gospel of Jesus Christ" (i. 1). Compare the language of Peter in Acts i. 22, x. 37 ; and that of Paul in Acts xiii. 24.

${ }^{2}$ Carlyle is by no means historically justified in his strong statement about conversion: "Blame not the word; rejoice rather that such a 
Among the Greeks this truth found its most definite recognition from Socrates, the man who has most frequently suggested comparison with Christ in his method of teaching. For in the teaching of Socrates the first aim was to produce a conviction of ignorance. Without this, it was reasonably maintained, no man will be stimulated to seek knowledge. But the purport of this method of training can be understood only when it is remembered that, in the Ethics of Socrates, virtue was in its essence identified with knowledge, and vice with ignorance. ${ }^{1}$ Among Christ's own countrymen not only had repentance been a theme of impassioned pleading by the prophets, but it seems to have become a general belief that a great national repentance would be the prelude to the kingdom of the Messiah. ${ }^{2}$ It was, therefore, in accordance with popular expectation that Christ was heralded by a forerunner who has come to be known in Christian history distinctively as the Preacher of Repentance.

Repentance has a twofold aspect, a negative as wcll as a positive. For the Christian attitude towards sin, in demanding amendment, requires that the sinner shall at once cease to do evil and learn to do well. This word, signifying such a thing, has come to light in our modern Era, though hidden from the wisest Ancients. The Old World knew nothing of eonversion; instead of an Ecce Homo, they had simply some Choice of Hercules. It was a new-attained progress in the Moral Development of Man: hereby has the Highest eome home to the bosoms of the most Limited; what to Plato was but a hallucination, and to Socrates a chimera, is now clear and certain to your Zinzendorfs, your Wesleys, and the poorest of their Pietists and Methodists" (Sartor Resartus, bk. ii. ch. 10).

${ }^{1}$ In that interesting picture of moral life, the Tabula aseribed to Cebes, $\mu \epsilon \tau$ d́vola takes an important place as indispensable to the rescue

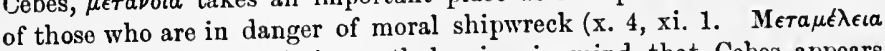
is used in $x \times x v, 4)$. It is worth bearing in mind that Cebes appears among the companions of Socrates in the Phado.

2 See Baldensperger, Das Selbstbewusstsein Jesu, p. 117 (2nd ed.), with the anthorities cited in the footnote. 
twofold recuirement is expressed with peculiar pith in a common Christian metaphor which indicates the thoroughness of the change implied. The penitent is described as, on the one hand, becoming dead to the old life of sin, while, on the other hand, he is born to a new life of holiness.

1. Probably it is the negative side of this change that is obtruded most prominently in the common idea of repentance or penitence. It is then understood to denote simply the emotion of sorrow excited by reflection on past sin. Such an emotion, however, is subject to great fluctuations from the various aspects which our past conduct may present. Some of these aspects may not touch the moral character of our actions, and any sorrow which they excite must not be confounded with the moral sentiment of penitence. It is but the natural sentiment of regret. In its shallowest form regret may be merely an insipid pensiveness, which is of little value for any of the purposes of life. But even when it is deepened into genuine anguish, it may imply no genuine repentance. It is often merely a bitterness of feeling at the folly of bringing on oneself the suffering which is entailed upon sin as its natural consequence. But this implies no unwillingness to enjoy the pleasures of sin, if only they could be obtained without the sting which they leave behind.

Regret may even assume the moral character which is commonly described as remorse without being yet true repentance. Remorse offers an interesting study to the psychologist, and has furnished a fertile theme for literary treatment, at times by the comical turn of its tortuous wrigglings, more frequently by its tragic issues. It often acquires that intensity of excitement which is commonly characterised by the name of passion. The sinner, in fact, is apt to become passive under its power, 
and it thus interferes with active repentance. The agony entailed may go beyond the limits of human endurance and produce an inhibitory effect upon the will. The remorseful sinner lapses into moral despair, abandons all hope of attaining or recovering a virtuous character. One of the Hebrew psalms gives plaintive expression to the peril of this emotional state: "Mine iniquities have taken hold upon me, so that I am not able to look up; they are more than the hairs of my head; therefore my heart faileth me." 1 The plaint of the psalmist is in the form of a natural hyperbole, and is immediately followed by a cry for deliverance. But the despair it expresses often leads to more tragic results. For the anguish of excessive remorse is generally at once the cause and the effect of morbid conditions in nerve and brain. These involve corresponding conditions of mental life. The sufferer lapses into one of the varied forms of insanity, perhaps into veritable aboulia or paralysis of will. His intellect becomes bewildered with illusions like that of having committed the unpardonable sin. $\mathrm{He}$ is tempted into wild excesses with a vain desire to drown remorse in intoxicating drafts of pleasure ; and often the close of the tragedy is a selfish suicide, a rush of blind despair into expected oblivion.

Such enervating despair, while generally immoral, is especially un-Christian. It crushes the very kernol of Christian faith. For if the penitent prodigal may not cherish the confident assurance that he will be welcomed on his return to the spiritual home which in his waywardness he had forsaken, then there is no meaning in

${ }^{1}$ Ps. xl. 12. This forms the psychological vindication of St. Paul's kindly advice to forgive and comfort the penitent, "lest by any means such a one should be swallowed up with his overnuch sorrow" (2 Cor. ii. 7). Paul's advice may have originated the line of thought and ecclesiastic procedure which developed the doctrine and practice of indulgences. 


\section{THE BEGINNING OF CHRISTIAN LIFE I67}

the glad tidings which Christ has proclaimed to the $x$ world. A doubt or disbelief of this, which is allowed to paralyse the penitent's aspirations, is therefore a real. infidelity to Christ. In many cases, indeed, it implies an infidelity far deeper than any purely speculative doubt. For, though it is difficult to analyse the subtle complications in the mental state of a remorseful sinner, yet in many cases it may be feared that his impotent despair is in reality an unwillingness to face courageously . the task of moral reform, a cowardly resignation to the easy course of drifting - a rudderless or unpiloted ship - down the stream into which his life has been allowed to float by indolent indulgence.

These facts enable us to understand why many writers have inveighed against giving way to remorse as a needless and fruitless form of self-torture. This has been the teaching not only of men like Spinoza, ${ }^{1}$ who leave no place for guilt in their view of the world, and therefore no reasonable ground for remorse. It is also the teaching of men who recognise the real difference of right and wrong, but regard the indulgence of remorse as an ille waste of energy which ought to be reserved for energetic endeavour to conquer the faults by which remorse is excited. This seems to be the meaning of St. Paul in that interesting analysis in which he contrasts a worldly sorrow for faults, which produces a deadly paralysis of moral energy, with that godly sorrow

1 Ethica, iv. 54 : "Pœnitentia virtus non est, sive ex ratione non oritur, sed is, quem facti pœnitet, bis miser seu impotens est." Compare iii. 18, Scholium 2, and iii. 51, Scholium ; and for a less technical statement, the Tractatus de Dcoet Homine ejusque Felicitate (ii. 10). Spinoza's definitions of penitence and remorse are almost amusingly naturalistic, non-moral. It is but fair, however, to add that his depreciation of them is almost purely speculative, an irresistible conclusion of his geometrical logic. In practice he allows them a certain value (iv. 54, Scholium). 
which produces an unregrettable repentance leading to salvation. ${ }^{1}$

2. But under this analysis, repentance passes over from a negative and passive attitude of remorseful reflection on the sins of the past into a positive attitude of active effort for future amendment. In this new attitude the past may be made, by its warnings, an aid rather than

- an hindrance to Christian life, bringing with it the cheering experience,

"That men may rise on stepping-stones

Of their dead selves to higher things." 2

There is, therefore, an earnest reason for deprecating idle worry over the irremediable past in view of the richer life which the future holds in store.

"So fret not, like an idle girl,

That life is dashed with flecks of sin.

Abide : thy wealth is gathered in,

When time hath sundered shell from pearl." 3

This attitude of comparative indifference to the past and comparative absorption in the future of life could not be more vividly pictured than in the familiar figurc of a man running a race. It is with this figure in view that the apostle describes himself as forgetting the things that are behind, while he strains cagerly towards what is still before him, in hope of reaching the goal of life and winning the prize of his vocation. ${ }^{4}$

12 Cor. vii. 10. It may be observel that grammatically $\dot{a} \mu \epsilon \tau a \mu \ell \lambda \eta \tau o \nu$ might be construed as a qualification either of $\sigma \omega r \eta p l a \nu$ or of $\mu \epsilon \tau a ́ v o l a \nu$; but the former construction appears to yield a weak meaning conpared with the other.

2 Tennyson's In Memoriam, i. 1. The thought seems not uncommon. It is more fully elaborated in Longfellow's The Ladder of St. Augustine, which appeared a few years after In Mcmoriam.

3 Ibid. lii. 4.

${ }^{4}$ Phil. iii. 14. In 1 Cor. ix. 25 the prize of the Christian race is finely 


\section{THE BEGINNING OF CHRISTIAN LIFE I 69}

This active outlook upon the future rather than inactive brooding over the past finds a happy expression in the New Testament term by which repentance is

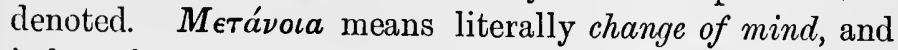
it has often been pointed out that there can be no real change of mind if there is no corresponding change in the conduct of life. Accordingly the penitence enjoined is never spoken of as merely a mental state of passive sorrow for sin. The very opposite, in fact, is explicitly

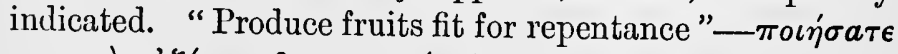

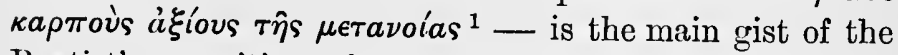
Laptist's exposition of what repentance implies; and in the fullest account which has come down to us ${ }^{2}$ we can see how this general injunction was applied to particular classes - to the rich, to publicans, to soldiers-who were attracted by his preaching.

Repentance is thus seen to be identical with that change of mind and life which by a variety of figures is described as conversion $\left(\dot{\epsilon} \pi \iota \sigma \tau \rho \circ \phi \eta^{\prime}\right),{ }^{3}$ transformation

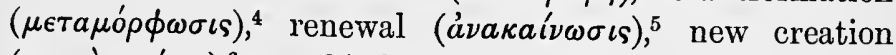
$(\kappa a \iota \nu \grave{\eta} \kappa \tau i \sigma \iota s),{ }^{6}$ new birth or regeneration $(\pi a \lambda \iota \gamma \gamma \epsilon \nu \epsilon \sigma i a){ }^{7}$ The common idea involved in all these expressions is the completeness of the change which they denote. That change is so complete that it seems, in Biblical

described as "an incorruptible crown," that is, an unfading or imperish-

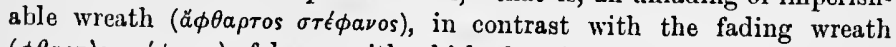
( $\left.\phi \theta a \rho \tau \delta s \sigma \tau \tau^{\prime} \phi a \nu o s\right)$ of leaves with which the winners in public games were crowned. The figure of the race receives another fine application in Heb. xii. 1-2.

${ }^{1}$ Matt. iii. 8; Luke iii. 8 ; ef. Acts xxvi. $20 . \quad{ }^{2}$ Luke iii. 7-18.

${ }^{3}$ Acts $x v, 3$. This is the only place where the substantive occurs in the New Testament, but the verb occurs often.

${ }^{4}$ Rom. xii. 2 ; 2 Cor. iii. 18. It is the verb that is used in these passages. The substantive does not occur in the New Testament.

${ }^{5}$ Rom. xii. 12 ; Tit. iii. 5 ; cf. Eph. iv. 23 ; Col. iii. 10.

${ }^{6} 2$ Cor. v. 17 ; Gal. vi. 15 ; cf. Eph. iv. 24 ; Col. iii. 9 , 10.

7 This idea is the most frequent and most distinctively Christian. 
language, to create "a new heart and a new spirit," 1 forming a "new man," while "the old man is put off" like a worn-out garment, ${ }^{2}$ is even got rid of so thoroughly as to be practically "crucified." 3

In this variety of metaphor it is needless to say that we should look in vain for a scientific definition of the spiritual change described, or for an exposition of any scientific theory of its nature. The variation of metaphor obviously implies that the beginning of spiritual life offers to the reflecting mind a corresponding variety of features. In this respect spiritual life simply represents the picturesque diversity which characterises the phenomena of nature in general, of animated nature in particular. Unfortunately, however, it is a common tendency of thought to take any phenomenon that is peculiarly familiar or peculiarly striking as an unvarying type of the whole class to which it belongs. Now the inner life in general can be known to outsiders only in so far as it is revealed in external life, and therefore its beginning never attracts attention except when it is obtruded into notice by something significant in a man's conduct. But such significance is seen most clearly in a sudden and violent change. Accordingly such a changc has come to be regarded as the normal and necessary mode of beginning the life of a Christian. This assumption calls for some explanations.

1. The phenomenon described as sudden conversion cannot be ignored except by closing our minds to obvious facts. But the real nature of these facts has yet to be ascertained. It is not yet clear whether the change undergone is in reality so sudden as it appears. This question has taken a peculiar phase from an hypothesis

1 Ps. li. 10 ; Ezek. xi. 19, xviii. 31, xxxvi. 26.

2 Eph. iv. 22-24 ; Col. iii. 9, 10.

${ }^{3}$ Rom. vi. 6 ; cf. Gal. ii. 20. 
which plays a prominent part among, the speculative 2 theories of recent Psychology. The hypothesis contends that our conscious life can be adequately explained only by the co-operation of mental activities which never rise into consciousness at all, and are therefore described as latent, subconscious, or subliminal. Applied to the phenomenon of sudden conversion, the hypothesis maintains that the suddenness is only apparent. It suggests that, prior to the conscious change, there has probably been going on, in the subconscious region of life, a more or less prolonged process which, at some critical moment, surges up into the sphere of consciousness. ${ }^{1}$

The interests of Christian Ethics need not be entangled in those of a psychological theory which still remains a subject of controversy. The truth is that the problem involved is not confined to the processes of mental life, but extends to those of nature in general. Sudden conversions do not contravene the Law of Continuity more than many other familiar facts. Even in the region of inorganic nature, with its comparatively simple mechanical combinations, such changes are obtruded incessantly. Take, for example, the transmutation of water from the liquid to the solid or gaseous state. A slight change in the temperature of water, that is, on the received scientific interpretation, a slight increase or decrease in the velocity of its molecular movements, is sufficient to convert it from a liquid into a gas or a solid; and the violence as well as the suddenness of the conversion is impressively exhibited in the enormous force created by the vast expansion into steam or even by the slight expansion into ice. Chemical changes are even more striking. The use of explosives in the industries of the

${ }^{1}$ Starbuck's The Psychology of Religion, pp. 105-113 (2nd ed.) ; James' Varieties of Religious Experience, pp. 236-237. 
world as well as in war furnishes an illustration of the astounding violenee and suddenness of changes which are porfectly natural processes. Nor are they in any sense extraordinary. They are, in faet, familiar in daily observation. There is, therefore, nothing in the general analogies of nature to make a sudden or violent conversion in spiritual life be regarded as unnatural, as inconeeivable or even improbable. It thus appears that , Ethics may, with perfect scientific propriety, recognise the fact of such conversions; and its interests do not demand any particular theory to account for the fact.

2. But it would be unfortunate if suddenness and violenee were taken to be normal characteristics of the beginning of spiritual life. It is not difficult to see how such a mistake may arise. Its source is to be found in the violence of the contrast between the lower and the higher natures in man, between sense and reason, between the flesh and the spirit. As we have seen already, this contrast had been drawn in rugged form and strong colouring by Greek Philosophy, especially in the Stoical school. Such a contrast tends to create, and it did ereate in Stoical thought, a sharp eleavage of the whole human race into two mutually exclusive classes, one governed wholly by the higher nature, another wholly by the lower. But this tendency of thought involves a further necessity to conceive the transition from one class to the other as an instantaneous act. It leaves no halting-place between the two. A man must always be wholly on one side or the other of the dividing line. This Stoical conception, as we have seen, was taken over into Christian Theology, and has often led to a rigid separation of men into the converted and the uneonverted, the regenerate and the unregenerate. But we have also scen that this separation is a mere abstraction of thought, and does not correspond with the actual facts 
of familiar experience. If the separate classes have no existence in reality, there is no act by which a man can transfer himself in a moment from one to the other. Notwithstanding any suddenness of change at critical periods, the normal processes of all life must be of the nature of growth and decay; and it is a significant fact, already pointed out, that our Lord's descriptions of spiritual life are most frequently based upon metaphors drawn from the process of organic growth in nature. Accordingly the beginning of spiritual life need not be signalised by any striking crisis. It may be an incident so unobtrusive as to be unnoticed or unappreciated at the time, and so early as to leave no trace in memory.

Happily there are numerous examples of a spiritual life which seems to enjoy a steady, healthy growth from childhood upwards. They are rarely or never marred by any lapse into serious moral disease or anxious struggle towards recovery. The charm of such a life may well evoke the aspiration of Wordsworth :

"The child is father of the man, And I could wish my days to be Bound each to each by natural piety."

The happy souls that enjoy such a development form a delightful contrast with those that reach a Christian life only through agonies of moral disorder in which the issue may remain long in fearful suspense. The contrast has been expressed ${ }^{1}$ by calling the former once-born, the latter twice-born. It must not be forgotten, however, that such phrases are metaphorical, and that a metaphor loses its value and even its truth if it is strained too

1 Apparently first by Francis W. Newman in The Soul: Its Sorrows and its Aspirations. James, in his Varieties of Religious Experience, uses the expression passim; but see especially the fourth and fifth lectures dealing with the religion of healthy-mindedness. 
far $^{1}$ It is natural enough to extend the analogy between spiritual and bodily life by describing the beginning of the former as birth,- a new-birth or regeneration. But the metaphor involved does not imply that there is anything like an identity between the spiritual change which it describes and the generation or birth of a physical organism. Nor is the metaphor to be understood as expressing merely the superficial idea of a second birth. This, indeed, seems to have been the first shallow confusion of Nicodemus when the necessity of regeneration was impressed on him by our Lord: "How can a man be born when he is old? can he enter a second time into his mother's womb, and be born?" 2 The fact indicated is something much more momentous than a mere repetition of the process of being born; it is the origination of a bigher life than that of the bodily organism. This is the fact brought out in the explanation by which our Lord removes the confusion of

${ }^{1}$ An illustration of this is furnished by a work which was extremely popular a few years ago, Professor Henry Drummond's Natural Law in the Spiritual World. Here the metaphors drawn from organic nature to illustrate spiritual life are treated, not as essentially poetical figures of speech, but as if they were prosaic statements of fact; and scientific inferences are deduced from that interpretation. But the result is fatal to the cause which the author has at heart. The phenomena of spiritual life $>$ are brought down to the same plane with those of physical organisation. But if both classes of phenomena are governed by the same natural laws, there can be no ground for asserting moral freedom and responsibility in the one any more than in the other. All that is distinctive of moral and religious life disappears. The method of explaining higher phenomena by lower can be carried out only by eliminating from the former all that differentiates them from the latter. Their intrinsic nature is thus ignored, and some extrinsic similarity with other phenomena is obtruded in its place. Professor Drummond's later work, The Ascent of Man, may be considered, if not an explicit recantation, at least an implicit correction, of the earlicr. Its general drift is to illuminate the lower by light from the higher. It might not inappropriatcly have been entitled, Spiritual Law in the Natural World.

2 John iii. 4. 


\section{THE BEGINNING OF CHRISTIAN LIFE I 75}

Nicodemus: "Except a man be born of water and of the spirit, he cannot enter into the kingdom of God. That which is born of the flesh is flesh, and that which is born of the spirit is spirit." 1 The whole drift of this explanation demands that $a \nu \omega \theta \epsilon \nu$ in the words of Christ be interpreted to mean "from above," "from a higher source," 2 rather than "again " or "anew." It contrasts

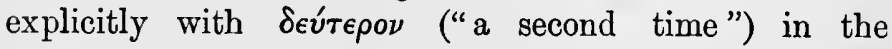
language of Nicodemus.

3. All this, however, is to be understood as by no means ignoring the value of sudden and violent conversions. Even their physical effects-the nervous and cercbral changes which they produce-seem to be highly beneficial at times. Under these organic changes morbid cravings have been known to lose their destructive tyranny, suddenly and permanently to disappear. ${ }^{3}$ But even for Physiological Psychology these effects are too obscure to afford any practical guidance in moral life. For the culture of moral habits, however, the shock of any intense impression upon the mind may form a potent initial stimulus, and in this fact must be found the main value of a conversion that is characterised by some suddenness and violence. But the value of such a stimulus is to be found in its impulsive force, and that force is very soon expended if it is not sustained by continued exercise. It is easy to see, therefore, that, valuable though sudden conversions may be under certain conditions, they are not without serious perils. Not to speak of minor perils incident to such conversions, the very magnitude of the change undergone, the glory of the new life begun, may prove a snare. For in his

3 John iii. 5, 6.

${ }^{2}$ Compare 1 Pet. i. 23 ; and note the repeated use of the phrase " born of God" in Jobn i. 13; 1 John iii. 9, iv. 7, v. 1, 4, 18.

${ }^{3}$ See James, op. cit. p. 268.'. 
young enthusiasm the convert is apt to overestimate his attainments; he may fail to realise that in spiritual life he is yet but a newborn child, and that that life lies all before him still with its innumerable daily tasks to be done ere he can grow to the stature of perfect Christian manhood. It is exceedingly important, therefore, to impress upon him that real conversion is no fleeting excitement of mind, not even a brief spurt of effort, however strenuous, but a toilsome, persistent exertion in which "the inward man is renewed day by day." 1 "It is one thing," says St. Augustine, "to look down from a woody mountain-peak upon the home of peace; it is another thing to hold the road that leads thereto." 2

\section{§3. Atonement}

It thus appears that the spiritual change by which Christian life begins is no remorseful passion paralysing the will. On the contrary, so far as it is impassioned at all, it forms a potent impulse to voluntary effort. Whatever remorseful anguish it may involve is more than counterbalanced by the joy and peace which the penitent attains in the consciousness that he has done with the sins of the past, that they are completely forgiven. This, in fact, is the very meaning of forgiveness ; it implies, in its very etymology, that sin is given away, surrendered, abandoned. The joy of being forgiven is not a non-moral exultation at evading the natural consequences of sin, or even its moral penalty. As to the natural consequences, these can never be evaded. The deed once done can never be undone. It has taken its place among the events by which the future is to be

12 Cor. iv. 16.

2 "Aliud est de silvestri cacumine videre patriam pacis; aliud tenere viam illuc ducentem" (Conf. vii. 21). 


\section{THE BEGINNING OF CHRISTIAN LIFE}

determined, and that place can never be taken from it by any power in the universe. But the moral retribution of an action forms part of its natural effect. The natural effect of an action may result, in part, from incidents of which the agent was unavoidably ignorant. To that extent the effect could not have been foreseen, could not have been intended; and therefore it cannot form an integral part of the action as a moral action. On the other hand, the moral retribution of an action must be intrinsically connected with its moral character, and must, therefore, be entailed upon it necessarily, universally. Now there is a result that never fails to attend a moral action, and is determined entirely by its moral character. That is the result following the operation of the law by which habits are formed. It is impossible to do any act, however trivial, without creating or increasing the tendency to act in the same way again, and to make the same kind of action easier. But it is this facility that constitutes habit. Consequently every action is requited appropriately the moment it is done. As every virtuous action is at once rewarded by a more confirmed habit of virtue, so every vicious action brings at once its natural penalty in a more facile inclination to vice. That is a doom which no ingenuity can elude. It tracks the skilfullest fraud equally with open crime, striking home with unerring certainty through the thickest veil of secrecy by which sin can be concealed from human ken. That is, therefore, but a sober statcment of rigid fact, that "every idle word that men shall speak they shall give account of in the day of judgment." 1

This fact makes it utterly meaningless, makes it a contradiction in the very terms used, to speak of sins being forgiven, except by being abandoned. But while the real nature of forgiveness is thus defined, its possi-

${ }^{1}$ Matt. xii. 36. 
bility is also assumed. This possibility, however, implies that the forgiveness or abandonment of $\sin$ is favoured by those laws of human nature and of external nature, which form the order of the universe and embody the will of God. But this also is implied in the very meaning of forgiveness. The forgiveness of sin means that the sinner has brought his will into harmony with the divine will embodied in the universal order, so that "to those who love God all things must co-operate for good." 1 It is true that speculation has sometimes conceived the mercy of God in forgiving sin as if it were in some way difficult to reconcile with $\mathrm{His}$ justice in pumishing the sinner. But this opposition of divine justice to divine mercy is a pure fiction of abstract thinking. There is no such disharmony in the will of God. So perfect rather is the harmony, it may be said that $\mathrm{He}$ is just precisely becanse $\mathrm{He}$ is inerciful, and merciful precisely because $\mathrm{He}$ is just. St. John does not hesitate to declare that "God is faithful and just to forgive us our sins." 2 Justice and merey, in fact, are but different aspects of goodness. For the will, which promotes only goodness, must be antagonistic to evil. That will must, therefore, appear in one aspect as justice inflicting upon evil its inevitable penalty, while in another aspect it appears as mercy forgiving the evil-doer who is penitent, by aiding his endeavour to escape from the evil of his ways.

It is evident, therefore, that to speak of a simner repenting, being converted, having his sins forgiven, is equivalent to saying that he is no longer at enmity, but at one, with God. It is this restoration of harmony between the will of the simner and the will of God that constitutes $\sim$ atonement. Theories of atonement have formed one of the most extensive battlefields of controversy; but the 


\section{THE BEGINNING OF CHRISTIAN LIFE}

interests involved are theological rather than ethical, speculative rather than practical. At least the rival claims of the controverted theories are of interest to us only in so far as they are connected with the problems of Ethics. But the postulates of Ethics cannot be ignored in any theory of atonement. Whatever else atonement may be understood to mean, it must at least include the transformation of moral character resulting from the reconciliation of the human will with the divine. That is the minimum of the demand which Ethics makes upon Dogmatics. In general this demand has never been refused, explicitly at least, by the great thinkers of Christendom. All sound doctrine, that is, all the wholesome teaching of the Church, has stigmatised by the name of Antinomianism any theory which would lead a sinner into the delusion that he can obtain forgiveness for his sins and atonement with God while he evades the inexorable obligations of the morality which constitutes Christian life. The very meaning and purpose of forgiveness are ignored in such a delusion. "There is forgiveness with Thee," says a psalmist, "that Thou mayest be feared." 1

${ }^{1}$ Ps. cxxx. 4. 


\section{CHAPTER IV}

\section{CHRISTIAN CHARACTER}

Character, as we have seen already, is, in the language of Novalis, a completely formed will; and a completely formed will is a will which has been trained into those uniform modes of action which are called habits. Accordingly Christian character is the trained will embodied in those habits which form the virtues of Christian life. For the description of these numerous data are to be found in the New Testament; and, as might be inferred from the very nature of the case, it is made an essential feature of Christian character that it should include every kind of virtue. While this is the general drift of the moral teaching of the New Testament, it is indicated with peculiar explicitness in the well-known sketch of Philippians iv. 8. Here the sketch is completed by a finishing stroke, "if there be any virtue," for the purpose of including any feature of Christian character that might have been overlooked. The effect of this stroke is fully realised only when it is remembered that the Greek word a $\boldsymbol{\rho} \epsilon \tau \eta^{\prime}$ bears a more extensive meaning than our English virtue. It would be represented more adequately by excellence. In the light of this fact, Christian morality comes to be appreciated in its catholic spirit and extent as according a place to all that is excellent in every sphere of human life, physical and intellectual as well 
as what is more narrowly described as moral and religious. ${ }^{1}$

But even where some detail is given in the enumeration of Christian virtues, they are not, in the New Testament, presented under the forms of scientific analysis or scientific classification. Such a presentation is the task of Christian Ethics. That task, however, requires that the virtues, which constitute Christian character, shall be shown to be necessary outgrowths of the germinal principle of Christian life. This principle was explained at the outset of our inquiry as being the love of God realised in the habitual love of our fellow-men. But it was explained further that love, as a principle of moral life, is good will, that is, the will to do good; and therefore Christian character may be described as the will of man trained to act habitually in $v$ loving harmony with the will of God. Accordingly the task before us is to show how from this source are developed the essential constituents of Christian character.

It has already been observed ${ }^{2}$ that in the analysis

'In Sidgwick's Method of Ethics, bk. iii. cl. ii. gives an elaborate explanation of the term virtue in contradistinction from duty. In Strong's Bampton Lectures for 1895, on Christian Ethics, there is also a valuable llote on the history of the Latin word virtus and its Greek equivalents (pp. 100-106). Besides a $\rho \epsilon \tau$,

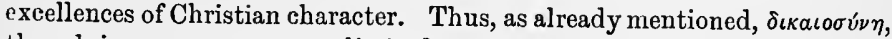
though in a narrower sense limited to bare justice, is often in the New Testament, as among Pagan moralists, extended to embrace all virtue. Occasionally ả $\gamma a \theta 0 \sigma u ́ \nu \eta$, goodness, occurs. In its more sacred or distinct. ively religious aspect virtue is described as $\dot{a} \gamma\llcorner 0 \sigma u ́ v \eta$, holiness, and (mainly in the Pastoral Epistles) $\epsilon \dot{v} \sigma \epsilon \beta \epsilon \iota a$, godliness. In this aspect, when conceived as a gracious gift of divine inspiration, it is spoken of, especially by St. Paul, as a $\chi a ́ \rho \iota \sigma \mu a$, and charism has thus been adopted at times in the literature of Christian Ethics to designate the graces of Christian character. An elaborate note on the terminology of Ethics in early Christian literature is appended by Dobschütz to his Die Urehristliehen Gemeinden, pp. 277-284.

${ }^{2}$ See Iutroduction, $\$ 1$. 
and classification of virtues, Christian moralists have often proceeded on some principle which is extraneous to Christian thonght, or at least does not form the dominant inspiration of Christian life. This procedure, indeed, has been by no neans universal. Angustine had already seen the necessity, for Christian Ethics, of developing all the virtues from the supreme principle of Christian morality; and in De Moribus Ecclesio Catholica he has even indicated how the four types of virtue in the received classification of the ancient world might all be described as different developments of the love of God. But his sketch is too brief for a scientific exposition, and indeed his little treatise is too largely taken up with a polemic against Manichæan morals to afford space for a satisfactory construction of his own system. ${ }^{1} \mathrm{He}$ has, however, indicated the method in which the Christian moralist must proceed in a scientific analysis of the virtues and in a classification guided by such analysis. It is, therefore, desirable to understand clearly what this method implies.

In the first place, it may seem scarcely necessary to observe that amidst all their diversities the virtues must retain a certain unity of principle. Among the ancient pagan moralists this unity received peculiar emphasis in the Stoical school. It was probably, in part at least, the influence of Stoical thought that gave prominence to this feature of virtue in Christian Ethics. But the prominence is also a necessity of Christian life. For the Christian an action ceases to be virtuous in the full sense of the term when it is divorced from the true inspiration of virtue. Accordingly there has been a common tendency to stigmatise as mere morality

${ }^{1}$ The fullest sketch is given in i. 15. $\Lambda$ briefer is given with slight change of language in i. 25 . But both are little more than bare definitions. 
conduct which, though conforming to, moral law, gives no evidence of a higher inspiration. This tendency has often been carried to an unhappy extreme. In eagerness to secure the kernel of Christian life, it has at times created some indifference about the shell of homely virtue, by which alone the kernel can be protected. It has led men to undervalue the inestimable gain of the common moralities, from whatever motive they may be observed. These have even been branded with the title of splendida vitia, as if they were more akin to vice than to virtue. But, after making all allowance for the extravagancies of Stoical and Christian moralists, the unity of virtue remains an essential truth. If the common forms of virtuous conduct are, under any inspiration, a gain to humanity, their severance from the highest inspirations of life is still a decided loss. It may even happen that external conformity to moral requirements generates an inertia of self-contentment which acts as a drag upon all efforts to rise into the heavenly region of spiritual morality, while that region remains accessible to those who, though flagrantly violating some of the moral proprieties, yet continue capable of a penitent discontent which spurs them on to higher endeavour. ${ }^{1}$

It will thus appear that any division of the virtues, however logical, can be regarded only as the modification of a common type into a variety of forms. The same, indeed, may be said of all seientific classifications. Yet there is a difference. In the mineral, the vegetable, and the animal kingdoms different forms are in general so distinctly marked that they can be easily arranged in separate groups. Even here, however, the lowest species of leading divisions are sometimes so indefinitely marked that science itself is puzzled to determine on which side 
of a dividing line they ought to be placed. This difficulty is vastly increased, it becomes the rule rather than the exception, in dealing with psychical phenomena. The day has gone by when Psychology can take the distinctions of common language as if they represented faculties and capacities of mind that are rigidly differentiated from one another. It is now recognised that the intellectual faculties of the old psychologistsperception, memory, imagination, reasoning, and the rest-are but habitual forms into which the elementary processes of intelligence are evolved. Those forms, moreover, even when evolved into definite habits, are not separated by any line of cleavage which prevents them from overlapping each other. Even the most distinct perception of an external object, for example, is a compound in which memories and judgments and generalisations play an essential part. It is still more difficult to take the passions of common speech,-love, hate, anger, pity, joy, sorrow, etc.,-as representing fixed types of emotional sensibility. The emotions generally are so transient and variable, that many psychologists have even denied the possibility of detecting among them any such fixity of type as is essential to scientific classification. 1

This feature of emotional life is peculiarly significant from its bearing on the classification of virtues. For, on any ethical theory, a very large factor of virtue consists in the regulation of the emotions. Consequently the classification of virtues must be attended with the difficulty found in classifying the emotions which they regulate. This difficulty has been aggravated, in Ethics

1 "Any classification of the emotions, if it only serves some purpose, is seen to be as true and 'natural' as any other" (James' Principles of Psychology, vol. ii. p. 454). Compare Jodl's Lchrbuch der Psychologic, lp. 378-380. Both psychologists are anticipated by Spinoza in Ethica, iii. 56. 
as in Psychology, by the misleading tendency to find in the categories of popular language the definite types of a scientific classification. But the common names of virtues form no more satisfactory nomenclature for ethical science than the common names of plants and animals for Botany and Zoology. Accordingly Aristotle, who first attempted to work out in detail a scientific definition of virtues, finds himself repeatedly obliged, for the logical completeness of his classification, to recognise types of excellence for which common language furmishes no names. ${ }^{1} \mathrm{He}$ has not attempted the coinage of a purely technical nomenclature for the virtues; he has in general contented himself rather with a more rigid definition of the terms in common use, or with a description of virtues which are essential to the perfection of moral character, though not distinguished in common speech. For all purposes it will be generally admitted that Aristotle's example may be followed with profit still.

In classification, as well as in nomenclature, the method of Aristotle offers the most useful guide. His method, indeed, is that of his master, Plato. It is, in fact, a method imposed by the very nature of the problem to be solved, and has therefore of necessity been followed in all classifications of virtue which make any pretence to scientific principle. For virtue in general is the $r$ highest excellence of human nature, and therefore the special virtues must be the various forms of excellence corresponding to the different spheres in which buman nature finds play. As we have seen already, Plato believed that all virtues could be comprehended in four supreme types, and this grouping came to be adopted as a traditional doctrine in Ethics. Only Aristotle, while following the method and even the general

${ }^{1}$ See, for example, Eth. Nic. ii. 7. 2-3, 10-13, iv. 4. 4, 5. 1, 6. 4. 
outline of his master, saw that an exhaustive classification must go into minuter detail, and must even recognise forms of excellence which cannot easily be brought under any of the four cardinal types. This is the method which the moralist has still to follow, and it will even be found that the leading features of scientific classification have been indicated by the ancients. The distinctive feature of our task is to keep the Christian ideal constantly before us in defining the several virtues, and in relegating each to its logical place in the classification.

\section{$\S$ 1. The Physical Basis of a Virtuous Life}

At the very foundation of all human excellence lies a condition which is indispensable because it forms an integral part of human nature. This is physical health. All effort to rise into the spiritual heights of morality, in order to assure its own success, must keep sight of the fact, that on one side of his nature man is an animal, and that complete excellence of life must comprehend animal well-being.

This does not mean, of course, that the sick or the feeble may not render loyal service to God, such as their condition allows and demands.

"They also serve who only stand and wait."

Christian teaching gives an insight into the divine significance of suffering, and directs sufferers in the discipline of the peculiar virtues in which their service consists. But their characteristic graces are not those of normal humanity, and it would be an unfortunate blunder to hold them up as ideals for men and women whose superabundance of healthy energy naturally overflows in the joy of vigorous work. In this con- 
nection an occasional complaint is, brought against religious teacher's of the young, that they put biographies of sickly children into the hands of boys and girls who are in the enjoyment of boisterous health. The latter must feel that the pathetic resignation and gentle grace, which fortunately have often been developed in feeble little sufferers, would be unnatural, morbidly artificial, in fact merely a sham, for them; and it would be in every way disastrous were they to gain the impression that such is of the essence of piety. There is a tendency in some scientific quarters to treat religion as if it were not a wholesome outgrowth of human nature, but rather a fungoid excrescence. It would be a matter of extreme regret if an unwise religious literature should even seem to countenance such a tendency; and it is, therefore, of infinite importance that Christian teaching from earliest childhood should be of a kind to illuminate the truth that there is nothing morbid in genuine piety, but that life attains the ideal of perfect health only when it is in perfect harmony with the will of God.

This fact has often been ignored, unfortunately owing to strange perversions of moral and religious intelligence, not only outside, but also inside of Christendom. Such perversions are probably for the most part connected with an extreme asceticism seeking a speculative vindication. Speculative essays of this nature show two tendencies which are sometimes combined. One is towards a physico-theological theory on the nature of matter as the antithesis of spirit, and therefore antagonistic to God ; the other towards a psycho-physical theory r on the relation of body and soul in man. Both result in a practical degradation of the material organism. This has manifested itself in the infliction of horrid, and often meaningless, self-torture, or in a disregard of all the 
wholesome amenities of physical life. Occasionally the tendencies in question lead to practical results which are opposed not only to extreme asceticism, but even to rational ascetic discipline. For body and soul are apt to be viewed as so completely independent that no real influence of the one by the other is conceived possible, not even such concurrent action as is recognised in the theory of Occasionalism or Parallelism. From this arises the illusion that even gross sensualities may be indulged without any fear of tainting the purity of the spirit.

These perversions of moral and religious sentiment originate apparently in a misunderstanding and abuse of wholesome ascetic disciplines. Such disciplines, as we shall see by and by, are useful, and even indispensable, for keeping the body under control ${ }^{1}$ and training the hardihood essential to a good soldier of Christ. ${ }^{2}$ But, as we shall also see, discipline defeats its own purpose, and may even create conditions unfavourable to morality, if it enfeebles, instead of invigorating, the body.

The perverted sentiment, which leads to ill-treatment of the body or even to neglect of its health, can have no foundation in religious intelligence. For it is the distinctive function of religious intelligence to interpret nature as the creation of God, and the laws of nature as an embodiment of His will. Any violation of the laws upon which physical well-being depends, is, therefore, to the religious mind a violation of God's will, that is, a sin. While the disregard of bodily health is thus seen to be incompatible with religious intelligence in gencral, it is specially incompatible with Christian teaching in regard to the physical organism. Even the Mosaic code contains sanitary regulations which put many modern communities to shame; but the whole subject of bodily health is raised into the region of the loftiest spiritual

11 Cor. ix. 27. 22 Tim. ii. 3. 
morality in the New Testament. Among the great religious teachers of the world, Christ occupies a somewhat unique position by the large proportion of $\mathrm{His}$ work that was devoted to the relief of bodily ailments. This consideration is not neutralised, it is not even weakened, by the destructive tendency that runs through a good deal of modern criticism in its treatment of the evangelical narrative of Christ's work in healing. It is indeed worth observing that a large proportion of the cures described in these narratives are far from being beyond the range of curative agencies recognised in the psycho-physical and medical science of our day. But independently of all possible results of criticism on the subject, it must be remembered that it is the Christ of evangelical history who has formed the ideal of supreme excellence for Christendom ; and it is an obvious historical fact that in His example and teaching must be found the most potent influence in the wider establishment of hospitals and other institutions having for their principal object the care of bodily wants. ${ }^{1}$

Among the apostles the language of St. Paul on this subject is characterised by peculiar force. It anticipates, in fact, by a change of metaphor, the common idea of modern science with regard to bodily structure and its functions. That structure in general is described as organisation, any individual structure as an organism, while its component parts, which perform the functions necessary for its existence, are distinguished as organs. It is not altogether unnecessary to be reminded that organ is a Greek word equivalent to the more familiar Latin word instrument. The term, therefore, embodies a metaphor. But, as we have seen already, a metaphor

1 Abundant evidence of this will be found in Dr. Uhlhorn's Christian Charity in the Ancient Church (English translation published by Charles Scribner's Sons, New York). 
loses its value when it is strained too far. We shall see by and by that this is often the case with the metaphor of organisation when it is applied to the structure and life of society; but it is also apt to be misunderstood even in application to individual organisms. In the mere animal and vegetable, indeed, the complete significance of structure may be exhausted by representing the component parts as organs or instruments for the maintenance of the whole. In man, however, this is not the entire significance of physical structure. Not only are the particular organs subservient to the uses of his whole organism, but the whole organism itself is a more organan instrumentality with which he is endowed for working out the destiny of an intelligent moral being. This is the idea which St. Paul has embodied in a different metaphor-a metaphor which is singularly noble, and seems to have been a favourite of his. It describes the body as a temple of the Holy Spirit, an abode in which God Himself is pleased to dwell. ${ }^{1}$ Not only is this conception of the body made the ground of the apostle's appeal against all sensual impurity as being a desecration of God's holy dwelling-place, but he entreats his Roman disciples to offer their bodies a living, holy, acceptable sacrifice to God as being the reasonable worship ( $\tau \dot{\eta} \nu$

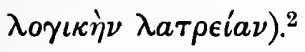

The tone thus set by apostolic teaching was sustained throughout the ethical literature of the early Church. An example is found in the Padagogus of the Alexandrine Clement. This work is very largely taken up with somewhat homely instructions in reforence to all the details of external life, and the instructions are repeatedly fortified by pointing to their importance or ii. 5.

${ }^{2}$ Rom. xii. 1. 
necessity for bodily health. ${ }^{1}$ Unfortunatcly the baneful influence of an irrational asceticism showed itself at an early period; yet the numerous works, which refer to the prevalent sensuality and luxury, naturally dwell also on the physical injury which results from the vices condemned.

The reasonable worship, recommended by Paul, which surrenders the body as an offering to God's service, implies obviously the acquisition of those means of subsistence by which life and health are sustained. These are, therefore, very properly connected with the highest aspirations of the soul. In the Lord's Prayer it may be observed that Christian sentiment descends quite naturally from lofty yearnings after the coming of God's kingdom and the doing of His will upon earth to the very homely petition for daily bread. But daily bread, that is, the means of subsistence, can be produced only by industrial labour; and therefore the prayer for daily bread becomes a real and honest craving of the soul only when the petitioner ceases to expect that the bread, for which he prays, will drop into his lap without any labour on his part, only when he is ready to undertake his fair share of the labour necessary for its production. In our time, when industrial interests are moulding the whole course of social evolution, the necessity of labour for the production of wealth is becoming a commonplace of popular thought as well as of economical science. The effect of this economical truth on the moral consciousness of the world will be noticed later. But meanwhile it may be observed that primitive Christian teaching, founding, indeed, on the teaching of Hebrew Rabbinical schools, is very definitely on the side of the labourers as against the idlers who

${ }^{1}$ See especially the second and third Books, and more particularly the first two chapters of the second Book on eating and drinking. 
live on the labour of others. In fact it seems emphatically to deny any man a right to the means of subsistence if he does not by his labour contribute, directly or indirectly, to their production. St. Paul gives utterance to the sentiment in what appears to have been a Hebrew proverb: "If any man is unwilling to work, neither shall he eat." 1

\section{$\S$ 2. Development of Cirristian Virtue}

In ascending from the physical to the mental conditions of virtue, we come upon a prominent feature of moral life, which perhaps characterises also life in general. It has been already observed that a large part of morality consists in the rational control of those emotional impulses which form the main motives of human nature. As these often thwart, and even baffle, the efforts of rational volition, moral life naturally assumes the appearance of a stuggle. All activity, indeed, implies a resistance overcome, even if it be but the resistance of inertia; and therefore the idea of activity, of exertion or effort, passes over very easily into that of struggle or conflict. Among the ancient Greeks, that brilliant thinker, Herakleitos the Obscure, saw that, as all existence is a ceaseless activity, its essential nature is war, a strife of opposites for the mastery. In the science of our day the favourite theory is that all life is, in its very essence, a struggle for existence. Whatever may be said of this theory, there can be no doubt that life in general, moral life in particular, presents at least the appearance of a struggle. Accordingly, in all literature, moral life is frequently deseribed under this figure, and as a description of Christian life in particular the metaphor is one of the 12 Thess. iii. 8-12. The proverb seems to be based on Gen. iii. 19. 
commonest in Christian literature. Our Lord Himself declares that the kingdom of heaven is won by violent exertion, that it is by men of violent energy that it is captured. ${ }^{1}$ St. Paul has more than once compared the Christian life to the prize-fights that were common among the great games of the ancient world. And he dwells on the intense reality of the conflict. For him it is no sham-fight as of one who is merely beating the air. $^{2}$ Nor is it any common wrestling against earthly foes, but rather a Titanic battle against the worldpower of wickedness in its highest spheres. ${ }^{3}$

Here we may find the truth embodied in the wildoats theory of moral youth, which is often illogically applied to confuse ethical thought. The excesses of youth are often condoned, if not even commended at times, on the plea that they are a sowing of wild-oats in the soil of moral life. It is assumed that by this treatment the soil is enriched and rendered capable of yielding a nobler crop in after years. The metaphor seems to point to facts occasionally observed in the earlier developments of moral character; but whatever may be the significance of these facts, they certainly can never be a justification for deliberately sowing wildoats in the hope of reaping a more cultured crop. It is, on the face of it, never allowable to do evil that good may come. But the truth is that the moral manhood, which sometimes follows the sowing of wild-oats in youth, is in no sense the effect of the indulgences described by the metaphor. It is the result rather of the struggle against these. For a steady, unwearied, triumphant battle with the passions of youth will, of course, develop a moral energy which is not so likely to be attained by men whose tamer nature never exposes them to conflicts of the kind. On the other ${ }^{1}$ Matt. xi. 12 ; cf. Luke xvi. 16. ${ }^{2} 1$ Cor. ix. $26 . \quad{ }^{3}$ Eph. vi. 12. 
hand, the unresisting indulgence of youthful passion inevitably entails moral enfeeblement. The whole gist of the wild-oats metaphor is expressed with admirable pith in the fifty-third elegy of In Memoriam:

"How many a father have I seen,

A sober man, among his boys,

Whose youth was full of foolish noise,

Who wears his manhood hale and green :

And dare we to this fancy give,

That had the wild-oat not been sown,

The soil left barren, scarce had grown

The grain by which a man may live?

Ol, if we held the doctrine sound

For life outliving heats of youth,

Yet who would preach it as a truth

To those that eddy round and round?

Hold thou the good: define it well:

For fear divine Philosophy

Should push beyond her mark and be

Procuress to the Lords of Hcll."

The plea for sowing wild-oats has been not only made general, but urged as if it were particularly applicable to the poetic or artistic temperament. It may, of course, be admitted as an elementary truism, that emotion even of a passionate character is essential to the highest æsthetic achievements. This fact is acknowledged to form a peculiar peril to moral wellbeing; and unhappily, therefore, it is not an unfamiliar tragedy in literary history, that

"The passionate heart of the poet is whirled into folly and vice."

The same truism is recognised in the sphere of moral life itself. The noblest moral achievements call for a certain fervour of enthusiasm, and a fervid sensibility has a perilous tendency to be set on fire with ease by any kind of passionate fuel. But 
neither in artistic nor in moral life should this truism be perverted into the illusion, that creative force is gained not by the control of passion, but by surrender to its tyranny. Milton points to the real source of a high poetic art in the noble words in which he repels a scurrilous criticism which had accused him of being tainted with the common literary profligacy of his day: "He who would not be frustrate of his hope to write well hereafter in laudable things ought himself to be a true poem, that is, a composition and pattern of the best and honourablest things; not presuming to sing high praises of heroic men or famous cities, unless he have in himself the experience and the practice of all that which is praiseworthy." 1

The control of emotional impulses is thus seen to be a prominent feature of moral excellence. It embraces the first and largest division of the virtues in Aristotle's classification. These he names distinctively moral excellences ( $\dot{\eta} \theta \iota \kappa a \grave{i} \dot{a} \rho \epsilon \tau a \grave{\imath})$; and, as the name implies, they comprehend practically all that is understood by morality or virtue in the common language of men. The other division of human excellences, the intellectual

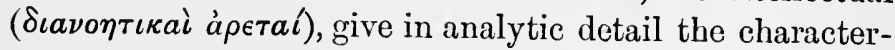
istics which are grouped under the general name of wisdom among the four cardinal virtues. But the truth is that, however valuable Aristotle's analysis of intellectual excellences may be, they cannot be separated by any sharp and rigid line from the other division. In actual life, as already explained, there is no absolute cleavage between emotion and intellect and will. The moral virtues, on Aristotle's own showing, consist in the control of emotion by practical reason, that is, by rational volition; and the intellectual virtues, consisting in the control of reason by itself, demand the

${ }^{1}$ See the preface to the Apology for Smectymnuus. 
control of non-rational emotions, by which it is apt to be biassed or blinded.

All virtue is thus directly or indirectly a control of emotion; and that is the reason why self-control passes current in common thought as equivalent to virtue. But this attitude towards emotion must not be confounded with that of Cynicism or Stoicism. The rigid Cynic or Stoic recognises no use in emotion at all, but would eradicate it entirely. Even Kant goes to an unreasonable extreme in excluding the natural emotions frow any place among the legitimate motives of virtuous conduct. He overlooks the fact that emotions become real motives, not in the rudimentary form in which they rank among the primitive instincts of our nature, but in the developed form into which they are trained by our own conduct, that is, by their habitual indulgence or restraint. An action, therefore, does not lose its moral character by receiving its stimulation partly or even wholly from a natural emotion. It may, in fact, be all the more virtuous if its stimulating motive is an emotion which has been trained into a virtuous habit, and not merely an isolated act of will which represents no fixed habit of life at all. That is a truer estimate of emotional excitements, which recognises their power as stimulants of action. As such they are capable of being used to originate and sustain exertion for the highest ideals, so that they may be made helps rather than hindrances in Christian life.

As already remarked, the inexhaustible variability of emotional impulse presents an obstacle in the way of classifying the virtues which consist in its control. It is therefore futile to attempt a classification with any claim to be rigidly fixed or exhaustive. ${ }^{1}$ Even leading

1 In an article on Modern Classifications of Dutics and Virtnes in the International Journal of Ethics for October 1907, the late Mr. W. L. 
types of virtue, like courage or temperance, which are recognised in common life or in ethical systems, are very variable in their forms; and probably the common language, by which they are designated, owes to the definitions or descriptions of moralists such fixity of meaning as it possesses. ${ }^{1}$ But, though a strictly scientific classification may be out of the question, it is still possible to arrange the leading virtues in such an order as is sufficient for intelligible description and for indicating the place which they severally fill in the building up of Christian character. These purposes may be attained by taking a prominent distinction which runs through the whole emotional life. That is thedistinction between pleasantness and painfulness. This could not indeed be made the basis of a scientific classification of emotions; for an emotion may, without losing its natural features, give pleasure or pain by simply altering its intensity or duration. But the $r$ distinction is one of supreme value in Ethics. The impulsive power of an emotion is intimately bound up with its pleasantness or painfulness. This at least determines the direction which its impulse takes. For that impulse is either toward or (to revive an old proposition) fromward the object, by which an emotion is excited. The attraction of pleasure and the repulsion of pain form the dominant incentives of our emotional nature, and the control of these gives rise to two types of moral excellence.

1. The general craving for pleasurable excitement is in English expressed by desire, ${ }^{2}$ just as the opposite Sheldon complains of the lack of scientific elassification; but he underestimates the intrinsic difficnlties of the subject.

'Speaking of Aristotle in this respect, Sir $\Lambda$. Grant observes: "His influence upon the forms of language of civilised Europe can hardly be overrated" (Note to Eth. Nic. ii. 7. 11).

2 Anong the Greeks, and therefore in the language of the New Testa- 
attitude towards pain is commonly denoted by aversion. The virtue, which consists in the rational control of desire, finds a place in every moral code, in every classification of virtues. It forms one of the cardinal virtues of the ancients. But it finds no name which, by etymology, indicates its specific nature. Accordingly we are obliged to be content with words like temperance, moderation, continence, sclf-denial, which denote a general power of restraint, and might therefore literally be applied to the voluntary regulation of aversions as well as desires. ${ }^{1}$ The virtue known by such names is itself modified into diverse forms by the great variety of desires which it may be understood to control. There is thus a tendency to narrow its requirements in accordance with the peculiar conditions of particular individuals or particular communities. Naturally and properly the moral consciousness calls for special care and special effort in regard to pleasures which from any cause tend to provoke a perilous strength of desire; and those who exercise self-restraint in the enjoyment of such pleasure are apt to flatter themselves that they fulfil the wholc demand of temperance, though they may be conspicuously lax in other forms of self-indulgence. It is

ment, this craving was fitly expressed by $i \pi i \theta v \mu i a$. Of this word the bad sense predominates in actual use; and this is indicated by the English translators of the Revised Version as well as of the Authorised, though in both the rendering varies. The most common rendering secms to be lust, though this noun has tended toward a more restricted meaning since the time of the older version.

${ }^{1}$ In Greek literature generally, as well as in the New Testament, temperance is denoted by $\sigma \omega \phi \rho o \sigma i ́ v \eta$. But it, too, enbodies a wider idea, which appears in its oecasional use. By etymology it denotes the state of a sane or sound mind. See Plato's Cratylus, $411 \mathrm{E}$, and Aristotle's Eth. Nic. vi. 5. 6. The literal meaning of the word is, therefore, brought out pithily by St. Panl in his speech before Festus. "I am not mad, but I utter the language of sane-mindedness" ( $\sigma \omega \phi \rho o \sigma u ́ v \eta s)$ (Acts xxvi. 25). Cicero uses variously temperantia, moderatio, and modestia to render

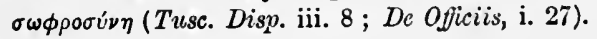


well, therefore, to bear in mind that the Christian ideal of this virtue cannot be reached except by being "temperate in all things." ${ }^{1}$ Nor is this ideal to be regarded as a mere fiction of imagination. It is rigidly enjoined by scientific thought; for it rests on irreversible facts of sensibility itself, as well as of moral nature. For the pleasantness of any excitement of sensibility depends on its moderation, and it passes over readily into pain whenever the limit of moderation is passed. The desire of pleasure, therefore, defeats itself, if it is indulged to excess. But excess also implies the abandonment of life to the rule of immoderate passion, and that means a dissolution of moral character, a relaxation of the habit of self-control.

The Christian ideal of temperance, however, as already remarked, does not demand total abstinence from pleasure, but a reasonable moderation in its enjoyment. In the eonception of temperance it is the moderation rather than the enjoyment that is brought into prominence; and eonsequently the fact is apt to be ignored, that there would be no room for temperance at all if enjoyment were not understood to be an essential feature of life. Practically, therefore, it may be said that the enjoyment of life is never enforced as a duty, evidently from the assumption that the natural desires are sufficient to secure that end without moral effort. There is thus supposed to be no temptation to deprive life of its due pleasures. Even Aristotle, carrying out his theory that every virtue is a mean between two faulty extremes, holds that temperance in actual life is opposed merely by one extreme--that, namely, of excess. "There are, in fact, none," he says, "who come short of their duty in pleasure by enjoying it less than they ought." ${ }^{2}$ For a Greek, with the joy in life which was

${ }^{1} 1$ Cor. ix. 25.

${ }^{2}$ Eth. Nic. iii. 2. 7. See also ii. 7. 3. 
characteristic of his race, this statement is not unnatural ; but even in Aristotle's time the Greek spirit was already shadowed by an ascetic gloom in the Cynic School. A constant saying of its founder, Antisthenes, was to the effect that he "would rather go mad than indulge in pleasure." 1 After the time of Aristotle the Stoics made it a main rule of their moral code to suppress all emotional excitement, whether pleasant or painful. The influence of Stoicism on the Ethics of Christianity has been already referred to; and the great wave of asceticism, which swept over Christendom at an early period, completely submerged in many quarters the rightful joyousness of Christian life. Even at the present day almost every section of the Church is in some degree infected with the ascetic spirit, creating, especially among the young, an impression that religion is essentially a joyless mode of existence. Outside of ecclesiastical organisations also there are men like Carlyle, who make it the very glory of Christianity that it is a "worship of sorrow." 2

Now it may be admitted that Christianity, by its whole system of thought, recognises with peculiar clearness the value of sorrow as a discipline of life, though this aspect of its teaching may be unduly magnified by ignoring the numerous recognitions of the same truth by moralists outside of Christendom, even among the Greeks. But, apart from that, it would involve a complete misapprehension of the Christian spirit to represent it as implying an exclusive worship of sorrow or even a depreciation of joy as a factor of moral life. For, in the first place, it is a familiar truth that the best work in every sphere of life is clone under

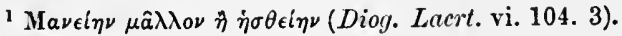

2 The idea runs through most of Carlyle's allusions to Christianity, and even this phrase reeurs several times in his writings. 
the inspiration of joy rather than of pain. All painful consciousness is indicative of some morbid process; and work that is stimulated by such a process must, almost inevitably, partake of its morbid character. The most efficient worker is the man who takes pleasure in his work, who has ceased to feel it a painful task. There is no reason for supposing that this law does not hold in moral life. The finest morality is not that which is regulated by a cool, passionless prudence. It is rather that which thrills with glad enthusiasm in the loving service of God and man. The plea has even been urged, that one of the principal contributions of Christianity to the moral culture of the world has been to raise morality from the plane of lifeless prudential regulations into the region of impassioned enthusiasms. "No heart is pure that is not passionate. No virtue is safe that is not enthusiastic. And such an enthusiastic virtue Christ was to introduce." 1

It ought to be borne in mind, further, that the fundamental ideas of Christianity enforce a view of life which must be optimistic in its general drift. The message of Christ to the world has been spoken of as a

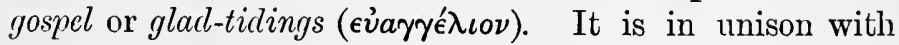
this that St. Paul declares the kingdom of God to be in its very essence "righteousness and peace and joy in the spirit of holiness." 2 The Christian consciousness, therefore, on its emotional side, is always described as brightened by sentiments which are totally incompatible with any pessimistic gloom. Among "the fruits of the spirit," "love, joy, and peace" take rank at the very top of the list. ${ }^{3}$ These phrases of St. Paul connect peace with joy, and the connection indicates the serenity of

1 Ecce Homo, 1. 8. See the same work passim, and especially eh. xiv., oul the Enthusiasm of Humanity.

2 Ron. xiv. 17. ${ }^{3}$ Gal. v. 22. 
the joy which forms a genuine fruit of the Christian spirit. All through the New Testament, in fact, joy and peace, either in union or as equivalents, are referred to as characteristic features of Christian sentiment. In this peaceful joy or joyful peace, therefore, as already remarked, the Christian realises in all its fulness that end which is often but inadequately described in ethical systems of the Utilitarian type-not what is commonly understood by pleasure or happiness, but that completer satisfaction of human nature which is denoted by bliss, blessedness, beatitude. ${ }^{1}$

Even in the earliest and simplest observations of mental life, joy has been connected with the emotion of hope. Hope is joy in prospect rather than in present experience. $^{2}$ This joyous attitude towards the future attains its highest power in what is distinctively characterised as Christian hope. For it is an outlook, not into isolated incidents of a happy nature, but into the completed sum of life; and it rests on faith in the infinite wisdom and love with which the Supreme Ruler of the universe makes all things work together for good to them who work in harmony with His eternal purpose. ${ }^{3}$ This hope is not to be conceived as merely a vague forecast of a glorious future for the world at large, with no particular reference to the individual persons who form the intensest of all realities in the universe. It has been already pointed out that the significance of the moral law is found in its appeal to individuals. ${ }^{4}$ Consequently a moral future of the world, which can form an intelligible object of hope for moral beings, is not merely the condition of a social organism, but the condition of real moral beings, that is, of individual persons. The full assurance of the Christian hope,

${ }^{1}$ See above, p. 117.

3 Rom. viii. 28.
2 Rom. viii. 24.

${ }^{4}$ See above, pp. 118-128. 
therefore, implies more than an outlook towards such a future society as may possibly be realised if this planet continues to wheel round the sun long enough and a number of other physical possibilities become actualities. Christian hope has been advisedly spoken of as at once a foresight and a foretaste. It is already a personal experience, faint it may be, but genuine, of the life which the Christian hopes personally to enjoy more fully in the future. Christian hope is "the hope of eternal life," ${ }^{1}$ of that eternal life which is already realised in the knowledge of God and of Christ. ${ }^{2}$

Strangely enough this hope of eternal life has been sometimes represented as tainting the moral life of men with an ingredient of selfishness. It is contended that a moral being attains a more exalted type of disinterestedness if his mind is freed from any thought of immortality. Now there can be no doubt that the belief in immortality may be, and often is, associated with hopes and fears of a coarsely selfish nature. It may be admitted, moreover, that the belief ceases to be a disinterested inspiration of the moral life whenever it degenerates into a hope of rewards or a fear of punishments that are not intrinsically moral,-a hope of any reward but that which goodness itself brings, or a fear of any penalty but that which is involved in the very nature of sin. Such, however, is not the Christian hope of eternal life; and the criticism which charges that hope with selfishness, arises from a confusion of thought as to what selfishness really is. We have already seen that selfishness is not any special regard for one's own interests, but rather a want of regard for the interests of others. ${ }^{3}$ In this sense of the term no one can pretend that there is any selfishmess involved in the Christian hope of immortality. Such a criticism is

${ }^{1}$ Tit. i. 2, iii. 7 .

${ }^{2}$ John xvii. 3.

${ }^{3}$ Above, p. 116. 
entangled in a dilemma of contradictions. For it must assume either that virtue is at best but a refined form of selfishness, or that it is essentially unselfish. In the former alternative, virtue must be conceived as consisting in a life of refined pleasure. But if this is the case, there can be nothing immorally selfish, nothing inconsistent with perfect virtue, in the wish to enjoy for ever those refined pleasures of which virtue is supposed to consist. If, on the other hand, virtue is essentially disinterested, then the Christian hope of immortality can be nothing but the hope of living an eternal life of disinterested virtue. This is the conception of Christian hope to which Tennyson has given utterance in a powerful little lyric on "Wages," which stirs the spirit like a trumpet call :

"Glory of warrior, glory of orator, glory of song,

Paid with a voice flying by to be lost on an endless sea-

Glory of Virtue, to fight, to struggle, to right the wrong-

Nay, but she aim'd not at glory, no lover of glory she:

Give her the glory of going on, and still to be.

The wages of $\sin$ is death: if the wages of Virtue be dust,

Would she have heart to endure for the life of the worm and the fly? She desires no isles of the blest, no quiet seats of the just,

To rest in a golden grove, or to bask in a sumny sky :

Give her the wages of going on, and not to die."

This conception of Christian hope becomes all the clearer when we bear in mind that the eternal life, which is its object, is that very life which was realised in Christ. In His life is revealed the law by which all life is governed. He has thus shown how, by alopting that law for the regulation of our conduct, we bring our wills into harmony with the will of God, we elevate ourselves above the Heeting conditions of time, we enter into a life that is eternal. It may, therefore, be said that $\mathrm{He}$ has done away with death, while $\mathrm{He}$ has 
brought life and immortality to light. ${ }^{1}$ As the life eternal has been realised in Him, we ean cherish the hope of realising it in ourselves, so that $\mathrm{He}$ is said to form "in us the hope of glory." 2 This glory, indeed, is one which in its fulness "eye has not seen, nor ear heard, nor has it entered into the heart of man" to conceive. $^{3}$ But we are vouchsafed an anticipation of what it implies. For "though it is not yet manifest what we shall be, we know that, when it does become manifest, we shall be like Him; for we shall see Him as He is." ${ }^{4}$ The Christian hope of eternal life becomes thus incompatible with the faintest ingredient of selfishness. It is the hope of becoming Christlike; and such a hope can have no meaning except as an inspiration to the highest unselfishness. "Every man that hath this hope in him purifieth himself even as He is pure." 5

The hope of the Christian reaches the highest degree of certainty. But that certainty manifests itself not only in the full assurance of the Christian's own mind. By a natural and necessary process of thought, this full assurance itself seeks its vindication in an objective and even an eternal foundation. Such a foundation it finds in the guarantee furnished by the will of God revealed in the moral history of the world, as that history is interpreted in Christ. ${ }^{6}$ This idea, that the full assurance of the Christian's hope finds its warrant in the will of God, has taken shape in the general doctrine of Election 2 as well as in the more special doctrine of the Perseverance of the Saints. These doctrines branch out into dogmatic complications which are not of essential import in Christian Ethics, but it is worth while to observe that the conclusion, involved in the doctrine with regard to the Perseverance of the Saints, had been reached by
12 Tim. i. 10.
${ }^{2}$ Col. i. 27.
31 Cor. ii. 9 (Isa. lxiv. 4).
${ }^{4} 1 \mathrm{John}$ iii. 2.
51 John iii. 3.
${ }^{6}$ Heb. vi. $13-20$. 
some of the early Greek philosophers working along the line of scientific Psychology and Ethics. As they based their conclusions on the laws of human nature, and as these laws are the most certain revelation of the Creator's will, the scientific and the theological doctrines must be interpreted as referring to the same class of facts. These are the facts connected with the operation of habit. For this peculiar operation attracted scientific attention at a very early period, just because it is among the most familiar experiences of daily life. Even to ordinary observation the continued repetition of an action produces such organic changes as to create confirmed habits of sufficient force to override and even obliterate native dispositions. In accordance with this law, the continued practice of virtuous actions must produce such changes in the very nature of a man as to make the habit of virtue practically irresistible and ineradicable. This ethical conclusion seems to have been definitely expressed first by Antisthenes the Cynic. $\mathrm{He}$ taught that virtue once acquired is something that can

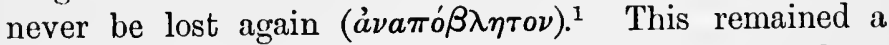
common doctrine among the ancient pagan moralists. Apparently it was the general belief of the Stoical School. It is especially ascribed to Cleanthes. ${ }^{2}$ It appears also in the Pilgrim's Progress of the Greeks, the Tabula of Cebes. ${ }^{3}$

It might not seem necessary to inquire, had the question not been raised, ${ }^{4}$ whether the serene joy of the Christian is compatible with those lighter moods which are described by such terms as mirth, merriment, fun, humour, the sentiment of the ludicrous or ridiculous. It may be admitted that emotional moods of this vein are often the very shallowest excitements of mental life,

Diog. Lacrt. vi. 105.

2 Ibid. vii. 127.

${ }^{3}$ xxvi. 2-3.

4 Dorner's Christian Ethics, p. $298 \mathrm{ff}$. (Eng. trans.). 
and not to be confounded with those deeper satisfactions which are implied in genuine enjoyment. It is a very old and common experience, that "even in laughter the heart may be sorrowful, and the end of that mirth is heaviness." 1 But after making all allowance for this, it remains a fact that there is a whole-souled mirth which naturally bubbles over with laughter at the comical side of things. It would be a serious blunder in Psychology and Ethics to put any rigid restraint on the natural explosions of this mirthful temperament. They contribute to the formation of that habitual cheerfulness of mind which is an essential factor of a thoroughly healthy morality. This fact, indeed, reminds us that the cheerful temperament, like every other, depends on bodily conditions; but it also prevents us from forgetting that teniperament reacts on these. In the interests, therefore, of bodily health itself there is a valuable truth in the Hebrew proverb, that " a merry heart is a good medicine." 2

It ought also to be borne in mind that the sentiment of humour is bound up with the higher nature of man. Only a being gifted with the intellectual faculty of comparison can appreciate the incongruity or oddity which forms an essential, if not the essential, factor of the ludicrous. There is no reason for supposing that it may not be an integral factor in the constitution of the universe, representing a feature of the Creative Intelligence. But, like all sentiments, humour is subject to the law of temperance. While moderate indulgence may be, what it is often called, a pleasantry, a real addition to the pleasantness of life, immoderation entails the inevitable penalty of excess. Not to speak of the suffering it may inflict on the innocent by unkindly

1 Prov. xiv. 13 ; cf. Eccles. ii. 2, vii. 3-6.

2 Prov, xvii. 22 ; cf. xviii. 14. 
jests at their expense, it reacts injuriously on the jester himself. For the more the mind becomes habituated to any form of excitement, the stronger is the stimulant required to yield its wonted gratification. In the course of time, therefore, the jaded sensibility fails to respond to the mild stimulants of a refined mirth, and seeks satisfaction in a coarse buffoonery which indicates a decided loss of intellectual and moral delicacy.

In this respect the requirements of Christian morality harmonise with those of comic art. For the aim of all genuine art is to give a pure intellectual pleasure; and whenever this aim is sacrificed to any extraneous purpose, the pleasure produced is no longer purely artistic, it is the pleasure which the extraneous purpose yields. Thus it is that, when the degradation of an object, and not its simple oddity, becomes the predominant aim, the product is no longer a work of pure comic art, it becomes distinctively satire; and the malicious taint in satire is, of course, aggravated if there is added a glow of triumphant self-exaltation over the degraded object. 'Tis true that a perfectly good-humoured comedy may naturally and legitimately produce a satirical effect, just as a scrious work of art may convey a great moral lesson. But in neither case must the extraneous purpose be allowed to overshadow the artistic aim. If an artist twists his materials out of all artistic shape in order to point a moral, the aim of his art is defeated; he may excite in us the feeling of moral approbation over his well-meaning labours, but he does not give us the pure rsthetic gratification that is felt in a work of art. In like manner, if the satirical purpose of a comic writer is forced to the front, we may possibly join in malicious triumph over the humiliated victim of his satire, but we shall not enjoy the disinterested fun which is the artistic or asthetic effect of pure comedy. Like comic 
art, Christian morality demands that our mirth shall be pure,-free from any poison or malice; and therefore the unsophisticated Christian consciousness is ready to declare with regard to all genuine satire:

"I loathe it: he had never kindly lieart,
Nor ever cared to better his own kind,
Who first wrote satire, with no pity in it." I

The whole of this attitude towards the enjoyments of life, notwithstanding its varied aspects, is comprehended under Christian temperance, when fully analysed; and temperance is thus seen to be a special embodiment of the universal principle of Christian morality. This seems to be the drift of the somewhat vague definition of temperance by Augustine, as "love yielding itself whole to that which is loved," or, as he modifies it in the next sentence, "love keeping itself whole and uncorrupted for God." 2

2. From the attitude of Christian morality towards pleasure we pass to its attitude towards pain. Here also, as already explained, virtue demands self-control, and our problem is to find out what self-control under pain implies. In the first place, there is, of course, a call for simple endurance, if not even a certain degree of indifference or contempt, of present pain when it is unavoidable, although this must not be understood to imply any fanatical surrender of the right and duty to avoid pain when it is unnecessary, or to relieve it when relief is possible. ${ }^{3}$ But the effects of pain are not

1 Tennyson's "Sea Dreams."

2 "Amor integrum se præbens ei quod amatur"; "Amor Deo sese integrum ineorruptumque servans" (De Moribus Ecelesia Catholice, i. 15).

${ }^{3}$ It is worth while to remember that the time is not yet very distant when the boon of anæstheties had to encounter a fanatieal sophistry which pleaded that their use interfered with the will of God as rcvealed in the order of nature. 
limited to the moment of endurance; they spread extensively over emotional sensibility. Even in psychological literature the emotional effects of pain are not always adequately analysed, and the inadequacy of this analysis has naturally affected the analysis of the virtues which imply self-control in pain. A full analysis shows that on different types of men the effect of pain is different. There are two leading forms of emotion excited by pain, though these may often pass over into one another, owing to the variability of emotional moods. In men of robust constitution pain tends to excite that rebound of sensibility which is appropriately described as resentment, or by such terms as temper, anger, irascibility. With persons, on the other hand, who may be characterised as of more delicate nature, the emotional reaction from pain is apt rather to take the form of fear. Consequently, in so far as virtue consists in the control of these emotional excitements, it assumes two types. The control of resentment gives the moral character revealed in what are spoken of as the gentler virtues; the control of fear yields the virtue of courage. These two types of virtue, however, from the affinity of their origin in the sufferings of life, are by no means alien to one another. A man may be gentle just because he is brave, because the complete control of a painful situation, which his bravery gives, may keep him from yielding to the cruel suggestions of an uncontrollable terror. On the other hand, men and women of gentle character have often braced themselves into heroic courage in the prospect or in the actual endurance of pain, just because their gentleness restrained them from yielding to any impulse of vengeful passion for their protection.

1. The affinity of origin in the two virtues has led to a somewhat superficial association of courage with irascibility $\left(\theta v \mu{ }^{\prime} s\right)$. All through the general literature 
of the ancient world it is represented as a sort of cultivated anger. Aristotle illustrates this by several quotations from Homer, ${ }^{1}$ and the tone struck by the earliest of the poets continues to be heard among the later. $^{2}$ There is an often quoted saying ascribed to Pythagoras, that anger is the whetstone of courage. ${ }^{3}$ The philosophers, indeed, corrected the confusion involved in this association. They saw that courage is essentially a rational control of fear-the natural shrinking from pain,- just as temperance is a rational control of desire -the natural craving for pleasure. ${ }^{4}$ In all languages, therefore, courage is commonly denoted by negative terms expressing the idea of fearlessness. We are thus in a position to understand the moral imprudence of playing so frequently on the emotion of fear in the educational discipline of childhood. Every kind of deterrent discipline, as the term implies, is of this nature. But the prominence of such disciplinary methods is open to grave ethical criticism. For, in the first place, the development of courage, as we have seen, is possible only by the suppression of fear. Now there are natural causes enough to excite this emotion under the most favourable conditions. It does not require any artificial stimulation. For general well-being, therefore, as well

1 Nicomachean Ethics, iii. 8.

2 See Aneid, v. 454, with Conington's note.

3 Sce Cicero, Acad. ii. 44, 135 . He speaks of controverting the statement elsewhere, alluding apparently to Tusc. Disp. iv. 36, 37.

${ }^{4}$ Courage has, on the whole, received admirable treatment in ancient literature. A higher conception of the virtue finds expression already in Thucydides, ii. 4, iii. 82. Among the philosophers the truer analysis begins with Socrates in Xenophon's $M e m$. iii. 9 , iv. 6 . Then follows Plato in Laches, which is entirely devoted to courage, and in the Republic, iv. 440. Aristotle gives a brief account in Eth. Nic. ii. 7 ; then a more elaborate in iii. 6-9. Cicero gives a fair summary of the best pagan thought on the subject just before the time of Christ in De Offliis, i. 18-26, and in the passages referred to in the previous note. 
as for moral training, it is a thoughtless cruelty on the part of parent or nurse to provoke in childhood a nervous timidity which may sap all strength of character. Then, in the second place, as a disciplinary force the use of fear is in many cases based on a psychological blunder. For the force of fear rests, physically on weakness of nerve, ${ }^{1}$ psychically on the power of vividly representing the pains which are to be feared. The physical condition of fear it is certainly unwise to aggravate, whether for bodily or for moral welfare. But the psychical condition of fear is apt to prove a broken reed in the hands of the disciplinarian. For it is a well-known law, that pleasure, being commonly the concomitant of healthful activity, is in general more easily revivable in memory than pain, which is commonly associated with activities that are destructive to life or health. In fact a robust constitution revolts against a reinstatement of the morbid condition which reveals itself in pain. Scientific methods of education, therefore, will trust more , to the attractive inducements of a plcasure to be enjoyed than to the deterrent repulsiveness of a pain to be avoided.

To this it may be added, in the third place, that, besides the psychological blunder involved in deterrent discipline, there is an ethical blunder which may often be more serious in its effects. For the object obtruded for the purpose of striking terror is not the sin itself from which the sinner is to be deterred, but some pain associated with the sin. Nor is it even the natural

${ }^{1} \mathrm{~A}$ brave man is often spoken of as a man of nerve; and therefore diseases which shatter the nervous system tend to produce a timidity which enfeebles moral energy in general. The combination of injunctions, "Be strong and of good courage," rests on a sound psychology. It need scarcely be said that it recurs repeatedly in the Old Testament. See Deut. xxxi. 6, 7, 23; Josh. i. 6, 9, 18, x. 25; 1 Chron. xxii. 13;

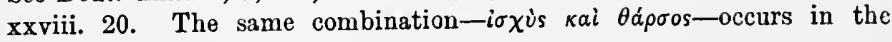
Tabula of Cebes (xvi. 5). 
penalty of the sin, the pain flowing from it by the inevitable operation of nature's laws. It is a purely artificial punishment, a pain invented for the purpose of frightening the sinner, but a pain that has no necessary connection with his sin. Consequently he is left, so far as this discipline is concerned, in the condition of being quite willing to enjoy the sin itself if he may escape its artificial penalties. His wits are therefore set to work to outwit the law by which he is punished; and too often the discipline intended to deter from a sin has simply the effect of stimulating the vice of deceit in order to escape the ineffective penalty. These facts have a peculiar significance in Christian Ethics. What is the main influence by which men are to be persuaded to the Christian life? Too often that influence has been sought in hideous pictures of the eternal punishment of sin, while that punishment is described as if it had no essential connection with the life of a sinner, but were some kind of physical or non-moral suffering arbitrarily inflicted by his Maker. Is it any wonder that the terrors of hell, as commonly conceived, even when eloquently depicted, exert so little influence over the human will? The wonder would rather be if the effect were different. Certainly it would be wonderful if any truly Christian sentiment were developed under such discipline, and it would be a miracle if Christian courage survived. ${ }^{1}$

The crucial test of courage has too commonly been made the power of facing death without flinching. The fear of death as a motive in human life is often greatly

${ }^{1}$ It is worth noting that in Rev. xxi. 8, along with "the unbelieving, and abominable, and murderers, and fornicators, and sorcerers, and idlolaters, and all liars," are classed oi $\delta \epsilon \iota \lambda$ ol, whose character is scarcely indicated by "the fearful" of our English versions. This was the common name for cowards, not only in general literature from Homer downwards, but more especially among the moralists, See Aristotle, Eth. Nic. iii. 6 and 7. 
overestimated. Every other motive, in fact, has conquered it at times. Still it would be very unfortunate if Christian teaching were in any way unfavourable to the development of that courage by which the fear of death is conquered. At one time there was a tendency to charge this fault against Christianity. Its teaching on the subject of death was contrasted with that of ancient paganism, greatly to the advantage of the latter. This contrast found its finest exponent in Lessing's ingenious treatise, Wie die Alten den Tod gebildet. But the most sympathetic and competent critics recognise that Lessing's interpretation of ancient artistic symbolism is by no means beyond question. ${ }^{1}$ On the other hand, the symbolism of the catacombs, whatever may be its artistic value, indicates a cheerful triumphant hopefulness in the outlook beyond death, to which there is no equivalent in pagan art. But when we look for pagan sentiment on the subject not in ambiguous symbols of art, but in explicit statements of literature, we are forced to a very different view from that of Lessing. There are, in fact, some passages quoted by Lessing himself which, as Sime remarks, "can hardly have been written without a shudder." And there is on the subject a great deal in ancient literature, of which Lessing gives no hint, which stands in startling contrast with the general drift of his work. Certainly Lucretius would have been astonished at Lessing's representation of ancient pagan thought about death. One aim which he professes in his great poem was to free men from fear of the eternal suffering which death was believed to bring in the gloom of Orcus and its desolate chasms. ${ }^{2}$ Even the sixth Book

${ }^{1}$ See Sime's Lessing, vol. ii. pp. 76-81, and Erich Schmidt's Lessing: Geschichte seines Lebens und seiner Schriften, vol. ii. pp. 163-166.

2 De Rerum Natura, i. 111, 115: " Eternas quoniam poenas in morte timendumst ; $A n$ tenebras Orci visat vastasquc lacunas." 
of the Aneid, with all its idealising, offers but a cheerless prospect after death to the great body of men, to all, in fact, but a few heroic spirits. Fortunately the essay of Plutarch on Superstition gives us in short space a very definite idea of popular sentiment even as late as his time. "Death," he says," "is an end of life for men, but not for superstition. On the contrary, it projects its limits beyond the period of living, making fear longer than life, adding to death the imagination of deathless evils, and fancying, when troubles cease, that ceaseless troubles begin. In the underworld abysmal gates are opened, rivers of fire mingle with streams of the Styx, and the gloom is peopled with manifold images, bringing grim sights and doleful cries, while there are also judges, and tormentors, and chasms, and caves filled with myriad evils." Even Lucian's Dialogues of the Dead, with all their lurid mirth, never convey the impression that the pagan could take a kindly view of death. Nor do they indicate the robust humour that finds sport in the pictures of the Dance of Death, or in a poem like Burns' "Death and Dr. Hornbook."

The teaching of Christianity, as of all other truth, is often encumbered with crudities of popular thought; and these may at times unnerve the courage of men in the prospect of death. But for such crudities no countenance can be found in the teaching of Christian Ethics. Of course any incident in physical life may exert an influence on moral character. A momentous event like death may therefore be peculiarly momentous in its influence, though that influence appears to be in general greatly overestimated. For death, in its own nature, is only a physical process. It does not necessarily involve any moral process whatever. Popular thought, therefore, crudely associating, if not

${ }^{1}$ Ch. 4. 
confounding, the moral processes with those of physical life, is apt to generate illusions as unspiritual as they are unscientific. Man is often pictured as passing into the presence of God and appearing before His judgmentseat by the mere event of physical death. But such phrases inevitably obscure the realities of spiritual life. Whatever fact they may express is enveloped in such an artificial clothing as to be effectively concealed from the common mind. Why foster the illusion that we can ever, for the briefest instant of time, escape from the Infinite Spirit of the Universe? To be with Him man does not need to wait till he has done with earthly life. Here and now every man is as near to that Presence as he can ever be in any place or at any time. Nor is the judgment, which be must face, an event postponed to some remote period or reserved for some remote tribunal. The character of every act is decided the moment it is done, and no power in the universe can ever alter that decision.

To the Christian, therefore, apart from attendant physical pain and the severing of old ties, death can have no terror. There is, in fact, no reason why he should fear to die more than to live. Everywhere and always he knows that he is in the presence of God, guarded by His love, and that neither death, nor life, nor any other thing can separate him from that love as revealed in Christ. ${ }^{1}$ It may, therefore, be safely asserted that nowhere is to be heard such a note of triumph over the last enemy of man's earthly life as that which rings through Christian literature.

2. The endurance of pain yields another virtue. It was pointed out that, as a rational control of fear forms the virtue of courage, so the rational control of resentment forms the virtue of gentleness. In explaining this ${ }^{1}$ Rom. viii. 39. 
virtue it is necessary to bear in mind that moral qualities are not to be confounded with natural instincts. Now the impulse of anger is instinctive. To that extent it is absolutely non-moral, it is simply one of the natural forces that make up the constitution of man. But whenever this impulse appears in consciousness, it comes within the sphere of the will; and its treatment, whether in the way of encouragement or of repression, becomes a moral act. Morality does not necessarily demand repression. For the resentment of wrong, especially of wrong done to others, is in itself rather a characteristic of vigorous moral health, while failure to resent wrong may be an indication of moral feebleness or of moral indifference. No such feebleness or indifference is to be found in the womanly tenderness, the forgiving mercy, which formed a characteristic feature of our Lord. He did not hesitate, when occasion called, to indulge a righteous wrath. $\mathrm{He}$ could look upon men with anger when $\mathrm{He}$ was grieved at the hardening of their hearts, ${ }^{1}$ and rarely has language of more impassioned indignation been uttered than that which He used at times. The natural and healthy instinct of resentinent may therefore be indulged without sin, with perfect moral propriety. Sin begins only when the angry impulse is indulged unreasonably — indulged without reasonable cause or to unreasonable excess. ${ }^{2}$ This is the common explanation of the well-known injunction of St. Paul_- "Be angry and sin not." 3 It is as if he implicitly acknowledged the propriety of well-timed anger, but urged the necessity of caution to

${ }^{1}$ Mark iii. 5.

${ }^{2}$ In Ecce IIomo there is a chapter on the Law of Resentment which is well worth reading in this connection.

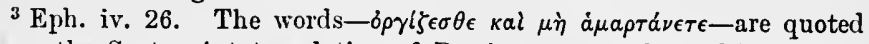
from the Septuagint translation of Ps. iv. 5 as a phrase likely to be familiar to both Greek and Hebrew Christians in the Church of Ephesus. 
prevent it from becoming sinful. For, like other natural impulses, anger is subject to sinful indulgence, and such indulgence is peculiarly alien to the Christian ideal. While that ideal does not refuse a rightful place to anger and the stern virtues which it stimulates, it is rather virtues of the type of "love, joy, peace, longsuffering, gentleness, goodness, meekness," which are signalised as the distinctive fruit of the Christian spirit. ${ }^{1}$

In this peculiar feature of its moral ideal, Christianity brought into prominence one of the finest tendencies of pre-Christian moral culture, especially among the Greeks. This tendency has been already sketched in its leading phases, ${ }^{2}$ and special attention may now be called to the place which Aristotle assigns to gentleness

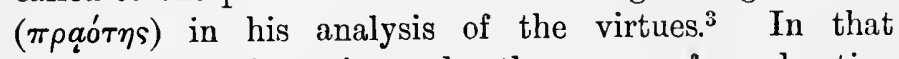
analysis this virtue is made the mean of moderation in anger; and it may safely be said that his description of the virtue, as well as of the faults to which it is opposed, anticipates the best thought of later moralists on the subject.4 Here it may appropriately be added, that among the Athenians the divine significance of the gentler virtues had received a characteristic expression, elevating them into the sphere of religious life. Among the numerous altars which formed a striking feature in the architecture of Athens, ${ }^{5}$ was one erected to Pity, "E $E \epsilon \cos ^{6}$ The earliest and fullest description of the

1 Gal. v. 22, 23.

${ }^{2}$ Above, pp. 75-89.

3 Eth. Nic. iv. 5. It is worth noting also that $\pi \rho a b \tau \eta s$ takes rank among the virtues in Cebes' Tabula (xx. 3).

+ In English ethical literature, Butler's Sermon on Resentment, with the companion Sermon on the Forgiveness of Injuries, has been commonly referred to as a classical treatment of the subject; but the bishop has drawn mainly on Aristotle.

${ }^{5}$ See Acts xvii. 22, 23.

6 "E $\lambda \epsilon$ os is the word usually represented by mercy in the English New Testament. Statius renders it by clementia. 
altar cccurs in a poem written about the close of the first century, the "Thebaid" of Statius." The poet's description naturally idealises its theme, so that his interpretation and embellishments can hardly be taken to represent more than the cultured ethical sentiment of his time. But the altar itself is no poetic fiction. It is mentioned, a century earlier, by Diodorus Siculus $;{ }^{2}$ and, a century later, Pausanias speaks of it as something he had seen in his travels. ${ }^{3}$ In the same century it is referred to by Lucian twice, ${ }^{4}$ and again at the very close of Latin paganism by Claudian. ${ }^{5}$

But, after making all legitimate allowance for such foretastes of Christian sentiment in regard to the gentler virtues, it remains a fact that these claim in the moral code of Christendom an import which had received but meagre recognition before. Indeed, as already observed, Christendom itself has in general failed to rise to an adequate appreciation of its own distinctive ideal. True, there is one form in which this ideal has found a beautiful embodiment, - an embodiment that yields to many minds a high rsthetic gratification as well as a pure ethical satisfaction. That is the worship of the Virgin. This is not the place to discuss the dogmatic or historical aspects of Mariolatry; but there seems to be little doubt that its power over minds of cultured refinement is due to the fact that it furnishes an object

1 Bk. xii. 481-496.

${ }^{2}$ Bk. xiii. 22.

${ }^{3}$ Bk. i. 17. 1.

${ }^{4}$ Demonax, 57 ; Timon, 42. In Lucian's sketch of Demonax occurs the story connected with a proposal to erect an amphitheatre in Athens. Demonax is said to have advised the Athenians "not to vote on the proposal till they had removed the altar to Pity." The story may be a fiction. In fact, Lucian's Demonax has all the appearance of being merely an idealised Cynic, and there is no independent voucher even for the existence of a philosopher of this name. Still Lucian's idealisation indicates the trend of ethical sentiment in his time all the more significantly from its contrast with the common cynical character.

${ }^{5}$ De Bello Gildonico, 405. 
of adoration which embodies the most distinctive features of the Christian character. If the Protestant claims, as he justly may, that our Lord realises in Himself all that divine gentleness which devout Roman Catholics conceive in His mother, then that gentleness ought to be made a more prominent reality in the daily life of Christendom. But every sphere of Christian society is apt at times to be marred by a harshness of bearing in painful discord with the gentleness of Christ, while the Church itself is frequently disturbed by "hatred, variance, emulations, wrath, strife," in brief, by all the types of irascible vice which form a horrid contrast to the peculiar "fruit of the spirit." 1

There is one feature of such vice, the moral significance of which is seldom adequately appreciated. That is its influence over moral intelligence. Common experience proves that no task is more futile than that of reasoning with a man "in a passion," that is, a man carried away by angry sentiment. Whether it be the violent fury of a sudden explosion, or the peevish humour of chronic fretfulness, or the sullen gloom of a sulky disposition, it is an universal tendency of angry men to charge their anger, not upon any flaw in their own character, but upon any person, sometimes upon any thing, that happens to be associated with it in the most incidental and innocent way; and in general no amount of explanation is able to bend the warped judgment back to a reasonable view of the facts.

This warping of moral intelligence, though peculiarly violent in the case of angry passion, is yet a commou effect of all uncontrolled emotion; and therefore all virtue, so far as it requires emotional control, implies the exercise of intelligence in directing emotional excitements. Without such intelligent direction even the ${ }^{1}$ Gal. v. ${ }^{19-23 .}$ 
best feelings of human nature are not to be trusted. In fact some familiar faults of character are obviously traceable to the lack of intelligence in directing even the better sentiments. Men often show " a zeal of God, but not according to knowledge." 1 If this ignorant zeal is accompanied with strong will, it results in dogmatism, opinionativeness, bigotry, intolerance, the fanaticism of the zealot or stickler for trifles, who is among the most impracticable of men to deal with in the social relations of life. On the other hand, when the lack of moral intelligence is combined with weak will, it is revealed in the caprice, irresolution or vacillation of those who are, with psychological truth, described as "children tossed to and fro, and carried about with every wind of doctrine." 2

The culture of virtue thus brings us once more a warning against the common error of scientific abstraction, which conceives the different activities of mental life as if they were independent of one another. The control of emotion, which forms the virtuous character, is a process for the direction of which reason is indispensable; and therefore in every classification of the virtues that rational control of conduct, which we call wisdom, takes an essential place. But the full ethical import of wisdom is brought out only in the interpretation put upon it by Christian Ethics. Then it becomes the trait by which character is rounded off into the full stature of moral manhood.

\section{$\S 3$. The Culmination of Christian Virtue}

By its etymology the word wisdom indicates that in meaning it is identical with knowledge. Wisdom is the condition of the man who may be said to wis or to wit,

${ }^{1}$ Rom. x. 2.

${ }^{2}$ Eph. iv. 14. 
that is, to know. ${ }^{1}$ But, as already pointed out, knowledge may, by scientific abstraction, denote the bare inactive contemplation of truth. In a concrete sense, however, that is, in a more real sense, it means the consent of emotion and will as well as of intellect, so that life comes to be controlled by the truth known. It is this fuller idea of knowledge that the term wisdom embodies. A man of disciplined intelligence may gain even a scientific knowledge of the physical, social, and moral laws by which human life is governed; and yet his own life may be ruined by his reckless disregard of these laws in daily conduct. Such a man has knowledge, but not wisdom. He may be a man of science, but he cannot be called wise. It may be added that the consent of our whole nature to truth is the idea expressed also by the term faith, at least in the richer meaning with which it has been charged in Christian usage. ${ }^{2}$

All these expressions, however, show a certain fluidity in their application. Wisdom and faith are sometimes degraded to the most meagre idea which knowledge can convey, while knowledge may be enriched with the fuller significance of wisdom or faith. It is not to be forgotten also that innumerable fallacies and illusions

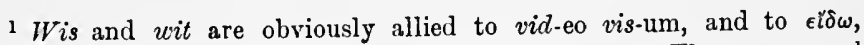

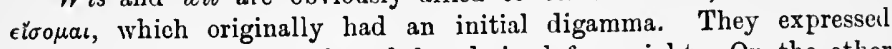
primarily, therefore, the knowledge derived from sight. On the other hand, the Greek $\sigma \circ \phi i a$ and the Latin sapientic denote at first the knowledge derived from taste. It is interesting to note that in one of the psalms these two ideas are used to represent the highest knowledge of which the human spirit is capable: "O taste and see that the Lord is good" (Ps. xxxiv. 8).

2 There is naturally a vast literature on the peculiar Christian application of the term $\pi i \sigma \tau$ is ( $f$ aith); but there is a recent note on the subject, specially deserving of mention, in Strong's Bampton Lectures for 1895 on Christian Ethics (pp. 107-113). It deals particularly with the use of the word in the New Testament and in the writings of the Fathers. 
pass current as genuine knowledge or wisdom. Moreover, there is often a tendency to overestimate mere keemess of intellectual insight above a simpler wisdom or faith which, though lacking in speculative perspicuity, is yet more effective in practical goodness. This tendency assumed startling prominence in the Church itself at an early period, and struck at the very core of Christianity by claiming the spiritual life as the peculiar privilege of a select intellectual aristocracy $(\gamma \nu \omega \sigma \tau \iota \kappa o i)$ into whose

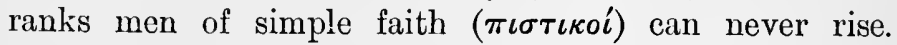
These facts explain the variations of meaning in which the words knowledge and wisdom and faith are used even in the New Testament.

At times, for example, the term knowledge ( $\gamma \nu \hat{\omega} \sigma \iota s)$

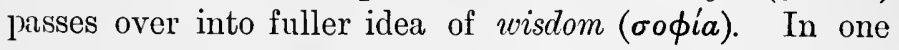
memorable utterance eternal life itself is said to consist in the knowledge of God and of Christ. ${ }^{1}$ In the Pauline Epistles also the term is frequently intensified with this spiritual import. It is in this import alone that knowledge is recognised as real. It is then distinguished from a " knowledge that is falsely so called." ${ }^{2}$ This is evidently what is elsewhere stigmatised as "the form or semblance of knowledge $;^{3}$ and if this phrase is compared with another which refers to those who have "a form of godliness while denying its power," ${ }^{4}$ we may fairly infer that it is meant to describe an idle acquaintance with truth, which wields no power over life.

While the term knowledge thus expands at times to the larger meaning of wisdom, on the other hand wisdom sometimes shrinks to the narrower meaning of knowledge.

1 John xvii. 3.

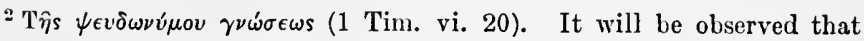
the word here used is not $\dot{\epsilon} \pi \sigma \tau \eta_{\mu} \eta$, as the Authorised Version would lead us to suppose. 'E $\pi \iota \tau \tau \eta \dot{\eta} \eta$ does not occur in the New Testament.

${ }^{3} \mathrm{~T} \dot{\eta} \nu \mu \delta \rho \phi \omega \sigma \iota \nu \tau \hat{\eta} s \gamma \nu \omega \sigma \epsilon \omega s$ (Rom. ii. 20).

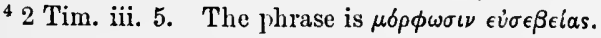


This was the case with oopia and cognate words among the ancient Greeks. The idea now attached to sophist, sophistry, sophistical remains a memorial of this degradation in one of its forms. Even in the New Testament the lowered meaning occasionally appears. Throughout the Epistles to the Greek Christians of Corinth, St. Pcul, recognising that the national bent of the Greek mind is to seach after wisdom, ${ }^{1}$ insists on distinguishing true wisdom from its spurious imitations. These he characterises variously as "wisdom of mere words," 2 "wisdom of the world," 3 " wisdom of men," 4 " carnal wisdom," 5-a kind of wisdom by which men have never come to the knowledge of God. ${ }^{6}$ It is worth observing that in the Epistle of James also the wisdom which comes down from above is in striking language contrasted with that wisdom which is of the earth, the wisdom of the animal, the wisdom of devils. ${ }^{7} \quad$ It will be remembered, moreover, that St. James guards against a similar abuse of the term faith to denote an idle inactive assent such as even devils may yield to truth, and he demands instead an active living faith which manifests its reality in the work of life. ${ }^{8}$

In light of the richer meaning thus given to wisdom and knowledge and faith, it is not surprising to find, in popular thought as well as in ethical speculation, a constant tendency to identify wisdom with virtue, vice with folly. And certainly, since the moral law under any interpretation is the law of perfect rationality in conduct, there can be nothing more unequivocally foolish

11 Cor. i. 22.

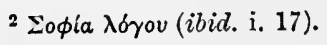

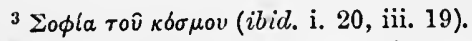

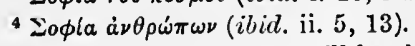

5 ¿офіа баркєкท́ (2 Cor. i. 12).

61 Cor. i. 21. Here, it will be observed, knowledge is the higher term.

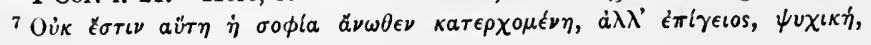
$\delta a \iota \mu \nu \nu \iota \dot{\omega} \eta \bar{s}$ (Jas. iii. 15).

${ }^{8}$ Ibid. ii. 14-26. 
than a vicious life, no more indispensable factor of wisdom than a life of virtue. This aspect of virtue and viee is peculiarly prominent in the ethical literature of Greece, and became even more prominent in the later literature of the Hebrews. In fact, it almost eclipses every other aspect in Proverbs and Ecclesiastes, as well as in the uncanonical books, Ecclesiasticus and The Wisdom of Solomon.

Wisdom, being thus identified with knowledge and faith in their fullest significance, is the recognition of truth by our whole nature. It is that complete consent which carries the fire of emotion and the force of will in the direction indicated by the light of knowledge. It is, in brief, practical intelligence in every form and sphere of its application. In Kant's language, it is practical rcason. But practical reason irresistibly raises the moral life into the religious sphere. Its imperative demand is that in every situation of life a man shall act upon a rule of conduct which is capable of being elevated into a principle of legislation for the universe. But that is merely another way of defining a rule which would be prescribed by an Infinitely Perfect Intelligence. Practical Reason, therefore, looking at the problems of life sub specie aternitatis, by the sheer necessity of its procedure, assumes the attitude of Universal Reason, becomes a veritable communion with God. In its highest development, wisdom is thus seen to be the attitude of mind described as piety or godliness, as the love of God.

We are thus brought back to the point from which wo started in secking the abstract ideal of Christian morality. We see again that the love of God forms the supreme principle $\left(\dot{\eta} \pi \rho \dot{\omega} \tau \eta \dot{\epsilon} \nu \tau o \lambda \eta^{\prime}\right)$ of Christian life, the principle which ought to call forth all the energies of our being, " the whole heart, and soul, and mind, and strength." But the love of God can mean only the complete harmony 
of our will with $\mathrm{His}$; and His will, as we have seen, ${ }^{1}$ is the will to do good,- - that will to do good which is understood by love in the proper sense of the term. Consequently this supreme principle involves as its

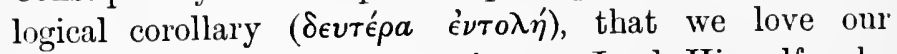
neighbour as ourselves. It is our Lord Himself who says that "greater than these there is no other commandment." "These contain, in fact, the whole gist of God's revelation to man. "On them hang all the law and the prophets." 2

Virtue, therefore, even when viewed in its subjective aspect as a form of self-culture, does not reach its culmination in mere self-satisfaction, however complete and however refined this may be. It carries the individual necessarily beyond himself in the cultivation of those habits by which he maintains a relation of love to his fellow-men. It brings us thus to the objective or social aspect of morality.

${ }^{1}$ See above, p. 25.

2 Matt. xxii. 34-40 ; Mark xii. 28-34. 


\title{
PAR'T III
}

\section{'THE CHRIS'IIAN IDEAL IN I'TS OBJECTIVE ASPEC'I}

\author{
CHAPTER I \\ GENERAL EXPLANATIONS
}

Tre necessity of personal culture to attain the highest ideal of life has at times an unfortunate effect. It gives a one-sided aspect to this ideal. In minds which have been already referred to as having a divine zeal that is not directed by knowledge, this zeal may obscure or oven obliterate the essentially social character of all genuine virtue. The moral ideal then takes on an anti-social or monastic character. But monasticism, distinctively so named, is essentially incompatible with the Christian ideal. The qualification here stated must not be lost from view. It is only monasticism distinctively so named, to which exception is taken; and that must not be confounded with an occasional resort to solitude. For occasional solitude, like any other discipline, is of high value, and generally even indispensable, for the Christian life. Christ Himself seeks solitude at times, and evidently as a human need. In fact, solitude is a need iu many ways. In the first place, it is a wholesome relicf from the distractions of social life, which interfere not only with repose and peace of mind, but with many of 
the disciplines which are necessary for intellectual and moral culture. Solitude is also a wholesome exercise in self-denial, in denying ourselves the pleasures that are found in the gratification of our social nature. But all such exercise is only a means of grace, a method of cultivating the Christian life; and to make the solitary life identical with the Christian life itself is to sacrifice the end to the means. It involves a moral flaw in its very nature, for it is a shirking of social duty.

Of course all monasticism is not unsocial. At least communities are often described as monastic, and a community implies social life among its members. Such social life may be limited in its extent, yet it is often very intense, - communistic in the use of its property, socialistic in subordinating the individual member to the requirements

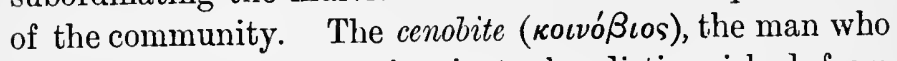
lives in such a community is to be distinguished from

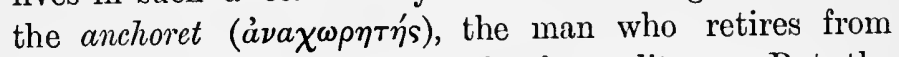
society in order to live the life of a solitary. But the anti-social tendency of such institutions is strikingly

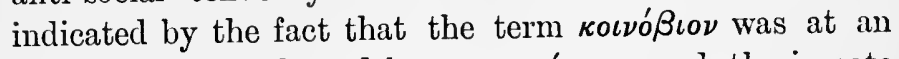

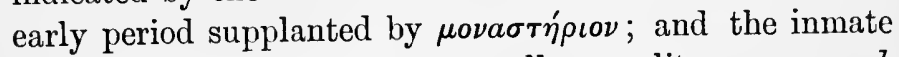
is spoken of as if he were really a solitary, a monk

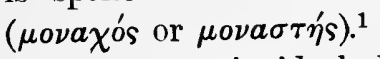

The monastic ideal, however, has a strong point of attachment in human nature, and has generally, therefore, made its appearance in all religions. It is, in fact, so natural, that it has infected the schools of pagan as well as of Christian Ethics. At an early period, as we have already seen, ${ }^{2}$ among ancient Greck moralists the idea gained ground, that that must be the wisest life for a man which renders him self-sufficient; and consequently

1 The etymology of nun is uneertain, but does not seem to imply any idea of solitude.

2 Above, p. 121. 
the problem of Ethics took the form of seeking to ascertain what constitutes such self-sufficiency. Notwithstanding the eminently social character of the morality inculcated by Christ, an anti-social tendency began at an early period to intrude into the Church, and in course of time had come to control a large part of its life, perverting its moral ideal. It is the tendency to seek in private culture rather than in social work the spiritual heights on which the Christian life should range. 'Tis true, the morbid and monstrous forms of this tendency, developed among the hermits of the early Church and in some of the monastic orders of the medirval world, have almost entirely disappeared; but there is no section of the Christian Church in which a large amount of moral energy is not still misdirected towards the realisation of an ideal which is substantially that of the solitary. In one of the most familiar hymns of The Christian Year, Keble takes occasion to protest against this morbid development of religious life :

\footnotetext{
"We need not bid, for cloistered cell,

Our neighbour and our work farewell, Nor strive to wind ourselves too high

For sinful man beneath the sky:

The trivial round, the common task, Would furnish all we ought to ask; Room to deny ourselves; a road To bring us, daily, nearer God."
}

The very phrascology of this protest, however, is a striking proof of the painful hold which the monastic ideal retains over Christian minds. To the poet the voluntary retirement of a cloistered cell, with its forsaking of neighbourly intercourse and work among fellow-men, did not appear as a morbid degradation of religious life, but rather as an elevation which, being too high for men in their present imperfect state, we cannot be required to 
attain, though we may aspire to it as the bliss of a state more perfect.

All sections of Christendom are tainted with the same tendeney to exalt the monastic virtues. Popular religious biographies are sometimes painful diselosures of the feverish eagerness with which a misdirected piety seeks, by self-tormenting disciplines of an excessive solitude, to find that inward peaee whieh ean never be permanently won but by going out in self-forgetful devotion to work for the good of others. This drift of religious life is also exhibited in the popular hymns of all Churches. A glanee through any eollection of these generally reveals a disappointing dearth of poetie fervour over the glory whieh illuminates a life spent in the service of others; and this laek appears in startling eontrast with the monotonous iteration of the satisfaetion which the singer is expeeted to find in solitary penitence and meditation and prayer.

But we must not shut our eyes to the hopeful proofs of a ehange which has eome over the Christian Chureh in this respect during the past generation or two. The numerous sehemes of benevolenee which are under the direet eontrol of partieular Churches, the numerous organisations for soeial improvement which, though unseetarian, are largely manned by Christian zeal,these are all praetieal recognitions of the truth that the > Christian life, like the life of Christ Himself, is a life spent in the service of men.

The obligations of that service arise from, and are determined by, the social relations into which men are brought by the exigenees of life. But these relations cannot be understood as long as they are eonceived to be formed by individuals existing in separate independence beforehand. There was a time when suel a conception tended seriously to mislead all the inquiries 
of social science. But this mistaken atomism has been $r$ long discredited. Even in physical science the atom is not conceived to be an independent entity capahle of existing by itself in complete isolation from everything else. The atom is defined to be what it is by its reaction with other atoms. So in human life the individual is what he is precisely in virtue of his relation with other individuals. That is merely another way of saying that man is by nature a social being; and this doctrine, notwithstanding occasional aberrations, has generally prevailed in the sciences which have to do with hunian life.

The doctrine has taken the form of a revolt against any conception of human society as merely a mechanical or adventitious collocation of independent units; and this revolt has been formulated in the description of society as being of the nature of an organism rather $v$ than of a mechanism. The social relations of men certainly receive a fuller interpretation when they are conceived as organic than when they are conceived as mechanical. But it must not be overlooked that both descriptions are metaphors at best. The language, therefore, which speaks of the mechanism of society, as long as it is understood to be merely metaphorical, may convey a truer meaning than the language which speaks of society as an organism, if this is taken to be an exact scientific definition. Such a definition it is r not. It fails in the lack of that adequacy which logic demands as the primary requisite of a definition. Society is more than an organism. The parts of which an organism is composed are merely organs, that is-to use a more familiar equivalent term-they are instruments whose use and significance lie in the service they perform for the whole body to which they belong. Not so is it with the social organism. Its 
members are not mere members. Each member is itself a separate organism. That is the case even with the societies that animals form. Even of these, therefore, the nature is but imperfectly indicated by comparing them to organic bodies. But the comparison is still less adequate to represent the nature of human socicties, less adequate by all the vast difference which separates man from the mere animal. ${ }^{1}$

We have now to see that all this is implied in the conception of society which is enforced by Christian Ethics. It seems to be assumed at times by recent writers that the analogy between association among men and organisation in nature is a discovery of modern science. But the idea was almost a commonplace of political thought in the ancient world. It is the very foundation of Plato's Republic. It runs through Aristotle's conception of the State too, and with a more scientific appreciation of its significance. ${ }^{2}$ Moreover, the first germ of the idea among the Greck philosophers was probably obtained from the talk of Socrates. ${ }^{3} \quad$ It remained a familiar thought among the Roman expositors of Greek philosophy. In earlier modern literature the very title of Hobbes' Leviathan implies that the State appeared to him like a huge organic bcing; and, all through the work, the likeness is elaborated in the fashion of the seventecnth century with quaint conceits of detail. The truth is that some of those in our day who insist most strongly on this

1 The conception of society as an organism has been subjected to a grood deal of criticism by recent writers. In Tarde's Etudes dc Psychologic Sociale (1898) there is a special essay on the conception, which describes it as "cette notion unanimement discreditée" ( $p$. 120). Compare the same anthor's La Logique Sociale, p. 133 (2me ed., 1898).

2 See, c.g., Politics, v. 3, 6.

3 Xenophon's $M \mathrm{em}$. ii. 3.

${ }^{4}$ Cicero, De Off. iii. 5 ; Scneca, De Ira, ii. 31 ; Epist. 90, 95. 
analogy do not apprehend its significance with the clearness of the ancient thinkers whom they ignore. Herbert Spencer, for example, and his school, whilew contending urgently that society is an organism, not a mere mechanism, undo their teaching to a large extent by their reduction of organic processes ultimately to mechanical. It is not, therefore, surprising that, in his treatment of the practical problems of political life, Spencer's conception of society as an organic union very largely disappears in an Individualism that is almost anarchical, in an uncompromising hostility to the most moderate extensions of collective action on the part of communities. ${ }^{1}$

Very different is the conception of the organisation of society which we meet with in the New Testament. For the metaphor which it involves was no exclusive property of philosophic thought in the ancient world. At an carly period of Roman history, in the well-known story of Menenius Agrippa, we find the metaphor applied with homely pith to reconcile contending factions in the republic. ${ }^{2}$ It may, therefore, be taken for granted that among the ancients it was regarded as a familiar, or at least easily intelligible, figurc of speech ; and consequently we are not surprised to find it employed occasionally by St. Paul to give point to his social teachings. The ethical implications of the idea he elicits with singular. clearness. He points out in general that such is the solidarity of human beings, that absolute independence,

${ }^{1}$ In the Philosophy of Nature, which is, of course, intimately connected with the Philosoplyy of Religion, it is interesting to note how the same School of Philosophy often empties evolution of all its meaning by redncing it, in the last analysis, to a mechanical process. If that analysis be correet, then there is no real evolution, no organic growth in Nature,-nothing but a rearrangement of the spatial relations of atoms and molecules.

2 Livy, ii. 32. 
whether in life or in death, is possible for no man. This mutual dependence is even definitely enforced by comparing it to the organic relation in which the different members of a living body stand to one another. ${ }^{2}$ The welfare of each individual member of society is shown to be involved in the welfare of all; and from this necessary interdependence of men by nature is inferred the moral nexus, by which they are all bound to work in the spirit of mutual love for the good of one another.

But this metaphor, with all its momentous ethical implications, has still a limit to its range. It is truc that, among primitive men as among the lower animals, society does not burst very effectually from the restrictions of a merely organic union. ${ }^{3}$ The individual is little more than a member of his family or clan or tribe. He scarcely attains to consciousness of himself as an independent personality. His moral worth as an individual, with its rights and obligations, is more or less completely absorbed in that of the community to which he belongs. Even the disinterested self-surrender, which gives often a touch of deep pathos to the incidents of tribal history, is not illuminated with the splendour of heroic self-sacrifice on the part of a moral personality acting with the full freedom of self-consciousness. It resembles rather the unreflective impulse of a natural instinct, the reckless devotion of an animal mother to her offspring. But when moral life is distinctly differentiated from instinctive activity, the concept of organisation can no longer represent adequately the social relations of men. For the individual is then

Rom. xiv. 7 .

2 It forms the theme not only of the elaborate exposition in 1 Cor. xii., but of several briefer allusions, as in Rom. xii. 4, 5 ; Eph. i. 23, ii. 16, iii. 6, iv. 4, 12, 16 ; Col. iii. 15.

3 See above, pl. 118-120. 
recognised as not merely a means to the ends of the social organism. He becomes an end to himself. But this idea has never found such clear expression as in the teaching of Jesus. As we have already seen, ${ }^{1}$ there is perhaps no truth more distinctively characteristic of that teaching than the infinite worth of the individual soul.

This great truth is of significance not merely in the spheres of morality and religion. It is of the highest value also for the light which it throws on the problems of social science. For it is evident that the government of society, both in its theoretical structure and in its practical administration, must never lose sight of this truth. Yet in social science and in social activity the truth is perpetually ignored. That is what gives momentous import to the clear, earnest, energetic enforcement of it in the teaching of our Lord. While $\mathrm{He}$ recognises the interdependence of men in their social relations, that is never allowed to conceal the independent worth of the individual. On the contrary, it is this independent and infinite worth of the individual that calls for the infinite obligations of mutual love 2 among men. For, while society may be spoken of as an organism, we must not misunderstand the moral implications of the phrase. It is quite true that men are related to one another as members of one organic body, and that each ought, therefore, to live for the well-being of the whole. But the whole that claims the self-sacrificing love of each inclividual is not the abstraction described as the social organism, but the whole of the individuals of whom that organism is composed. It seems to be taken for granted that the organism has some independent worth in itself apart altogether from its living members. In moral and

${ }^{1}$ Above, pp. 121-128. 
political thought a fallacy of Division and Composition warps the judgment. The composite whole is mistaken > for its component parts. The individuals, who are the realities in the social body, are treated as if they were merely organs of that body, and must be ruthlessly sacrificed for some supposed good which it may enjoy independently of them. Now, while it is important to remember that, in one point of view, the individual members of a community are organs serving as means to promote the ends of the whole, it is equally important not to forget that there is another and truer aspect, in which the social organism is merely a means to promote the well-being of its individual members. In this aspect, all social institutions, laws, and customs find their rational vindication only by being adapted to promote the good of real human beings. This political truth has found illustration by a felicitous example in the teaching of our Lord with regard to the Sabbath. For His great utterance about that institution holds equally of all others; they are made for man, not man for them.

We are thus in a position to face the problem of the ethical relations which the Christian should hold to society. The forms of society are various; in other words, men form many kinds of societies for the purpose of united effort in promoting their common ends. Most of these societies are adventitious; that is to say, they are purely voluntary associations formed by a limited number of individuals to promote some particular object in which they all take a special interest. We 7 have thus innumerable societies for almost every conceivable object that can interest the human mind. But besides these non-essential forms of society, there are others that are indispensable to human life. They are those in which alone the necessary and universal 
ends of humanity can be attained. They grow, therefore, out of the nature of man as an intelligent moral being.

There are three forms of society which are of this necessary character for man. These are the Family, the State, and the Church. The first is based on that relation of human beings which is formed by nature, and which is therefore spoken of as natural relationship or kindred. In the second, man forms a new relation, beyond the relationships formed by nature, for the purpose of securing those social conditions without which human existence is impossible. But there is an ideal of human life transcending that which can be enforced in the external conditions of social existence. This ideal may be described as purely spiritual, inasmuch as it is to be attained only by intelligent and voluntary effort, without any extrinsic compulsion. The association of men with a view to this ideal is the Church. It must not be supposed that, in actual life, these three types of society have always been separate. It would appear even as if human history had in general begun with a simple society, in which the functions of Family and State and Church were indistinguishable. There is certainly no differentiation of these in that social condition which is supposed by some sociologists to be most primitive of all, in which descent is traced along the female line, and which is therefore distinguished as matriarchal. But all the great civilisations have grown out of a patriarchal society; and in it the pater familias is also chief or king, and priest as well. A great part of the whole history of the world draws its interest from the struggles connected with the differentiation of these social groups and the delimitation of their respective spheres.

For general purposes it is perhaps most convenient 
to treat of these in the order in which they have just been mentioned-Family, State, Church. But in Christian Ethics there is an obvious propriety in beginning with the Church, as that is the society of which the special function is to develope the Christian life, and which must therefore determine Christian ideas of the family and the State. 


\section{CHAPTER II}

\section{THE CHRISTIAN CHURCH}

HERE, it must be remembered, our problem is ethical, not dogmatic or historical. The theory of the Church as a doctrine of Christian Theology, the development of the Church as a fact of Christian history,- these are subjects to be studied elsewhere. We have here to do with the ethical attitude of the Christian to the social organisation which goes by the name of the Church.

1. At the very outset of this study we encounter the perplexing variety of Churches, with their rival claims. It is true, there is a conception of the Church which seems to abolish this rivalry by abolishing the variety out of which it arises. That is the conception of the Church as invisible. In this aspect the Church is viewed simply as that ideal community of spirit among all true Christians which is commonly spoken of as the communion of saints. With regard to the Church in this idcalised significance there need be no ethical controversy. The catholic creed of Christendom-it may be said, even the catholic creed of all who under any name aspire to saintliness of life-makes the communion of saints onc of its fundamental articles. It is in regard to the socalled visible Church, that is, the Church as a real social organisation, that the problems of moral life arise. Now that Church at once creates a perplexity for the moral 
life of Christendom by the variety of its forms. If we face this perplexity frankly and intelligently, it is impossible to evade the historical aspect which it presents. This point of view has value in many ways. In the first place, it calls for the strictly historical attitude in studying all the varieties of organisation and of spiritual life which the different Churches display. But this attitude is that of a perfectly truth-loving spirit, seeking to discover the actual conditions under which the various Churches have arisen, and to appreciate the work which they have severally accomplished in promoting Christian life. This spirit of listorical impartiality enables us even to see a certain significance in the varieties of Christian faith and life which find embodiment in the different Churches. For

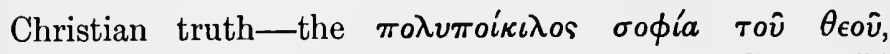
which had to "be made known through the Church" 1 -is so many-sided that it cannot be adequately expressed in any single type of Church life. Its many-sidedness, in fact, finds but an imperfect embodiment in all the Churches taken together.

But the historical point of view has another advantage. It enables the Christian more truly to appreciate, not only the Churches in general, but his own Church in particular. He will learn to appreciate the special testimony to Christian truth which its history has called it to bear; and he will probably find that its special mission, when interpreted historically, does ' not interfere with its being for its members a welcome vehicle of the catholic Christian spirit. For most Christians the connection with a particular Church is not, in the first instance at least, an act of their own choice. It is the

${ }^{1}$ Eph. iii. 10. Professor James has some excellent remarks on the value of religious variety, "without which the total human conscionsness of the divine would suffer" (Varieties of Religious Expericnce, 1. 487). 
Church in which they have becn born and bred. It is a higher and wiser Will than their own that sends them into human history in connection with a particular family and a particular State. With any genuine faith in ther providential government of the world, the Christian cannot allow himself to believe that such a connection has been created for him from the first without any rational purpose; and he will not, without some reason of overpowering force, abandon the advantages which sucl a comnection guarantees. The habits of his spiritual life are monlded from childhood by the saered rites and the kindly associations of his native Church. Its forms and companionships will generally be best adapted to promote his own spiritual well-being as well as to stimulate him in work for the well-being of others. This is not, of course, to be understood as precluding all change of Church connection. But it must be an unusually deep change in a man's spiritual life that can warrant or compensate the wrench of all the potent associations which have formed his early religious habits. There can be little doubt, therefore, that, as a rule, the spiritual life of every Christian is fostered most effectively in the Church to which the habits of his life have become adapted. This general principle, as we have seen, appears to receive the sanction of our Lord Himself in His limitation of His own work to the lost sheep of the house of Israel.

2. But whether the Christian's attachment to a particular Church has been formed at birth, or subsequently by his own voluntary act, it entails certain obligations. These must be so interpreted that, while they require a peculiar devotion to his own Church, that devotion shall not interfere with the rights or the interests of others. Such a devotion, like that which family and State denand, is often spoken of as loyalty; and there- 
y fore we are called to consider what loyalty really implies in Christian life. ${ }^{1}$

(1) First of all, then, Christian loyalty does not mean sectarian hostility to other Churches. This negative aspect of loyalty it is of infinite importance to inculeate. For the unedifying polemics of Christendom in all ages prove that such a conception of loyalty has been only too prevalent. To some also it has seemed inevitable; and they have therefore advocated and adopted an attitude of aloofness in relation to all the Churehes, as if by this radical step alone the catholicity of the Christian spirit could be sustained. But is catholicity of spirit inevitably prejudiced by connection with a particular Church? It is true that men cannot escape from the bias of their associations. But religion is not distinguished by imparting any abnormal intensity to that bias. There is therefore no special reason for avoiding the influence of fellowship in religious life. Such a course, if logically carried out, would prevent men from uniting with their fellows in the promotion of any common object, if such , union brought them into conflict or rivalry with another party. ${ }^{2}$

(2) But if loyalty to a particular Church is not, and does not necessarily entail, a narrow sectarianism, what does it imply? It implies obviously earnest effort, on the part of every Christian, in promoting the wellbeing of every Church. Now the true well-being of every Church is in direct proportion to its efficiency as an organ of the Christian spirit. But that efficiency can be maintained only by maintaining a high ideal of Christian life among the nembers of the Church

${ }^{1}$ A recent work has appeared on this suljeet by Professor Royee of Harvard University, The I'hilosophy of Loyalty (The Maemillan Comprany, New York, 1908).

2 I have discussed this question at length in an article in The Intcr. national Journal of Ethics for $\Lambda_{1}$ ril 1904, Pp. 353-362. 
generally; and this the individual can do most successfully by being a consistent illustration of that ideal in his own life. This ideal, however, implies further, that he maintains a Christian character not only in the general relations of human life, but in his special relation to his own Church. His loyalty must be a loyal regard for its institutions, its ritual, and its ecclesiastical methods in general, so that they may be effective means of grace to himself and his fellow-members.

3. In order to this it must be borne in mind that all the forms of Church life are merely means to an end. But, as in other spheres of life, the means are apt to conceal the end and to become a substitute for it. The history of all religion proves that this has been the fruitful source of its corruption in every age and in every part of the world. Under this corruption the services of the Church are apt to degenerate into "bodily exercise which profiteth little," ${ }^{1}$ to become a mere "form of godliness," the power of which is ignored. ${ }^{2}$

As a revolt against this corruption, some have gone to the extreme of abolishing forms of worship altogether. This radical step seems to represent a natural tendency of the human mind, for we find it under various phases of religion. Philostratus tells us that Apollonius of Tyana prayed to God always in perfect silence, holding that no language is adequate for addressing the Supreme Being; and though the Life of Apollonius is more of a philosophical romance than a biography, yet this trait in the religious life of the hero may be taken to represent a not uncommon tendency of ancient pagan mysticism. The mystical movements also which have made their appearance from time to time in Christendom, have been characterised by a general indifference to stereotyped forms of worship. But perhaps the most

$$
{ }^{1} 1 \text { Tim. iv. } 8 .
$$

22 Tim, iii. 5. 
systematic embodiment of this tendency, the most formal assertion of formless worship, is the peculiarly interesting English movement in the seventeenth century which originated the Society of Friends. The movement involved a general protest against the use of forms which are not created by the Spirit in all spheres of life. Worship particularly was regarded as " a silent waiting upon God." It was therefore held to be incapable of being preached or practised "but by such as find no outward ceremony, no observations, no words, yea, not the best and purest words, even the words of Scripture, able to satisfy their weary and afflicted souls, because where all these may be, the life, power, and virtue which make such things effectual may be wanting." 1 It is pleasingly significant to find that the great champion of Quakerism, from whom these words are quoted, recognises mystics like Bernard, Bonaventura, Tauler, Thomas à Kempis as having "felt the power and virtue of God's Spirit" even " in the darkness of popery." 2

There are obviously two extreme views with regard to forms of worship. One is based on the fact that the spirit can sustain its vital vigour only by constant expression in some form; but it misinterprets this fact by pitching on a particular form, generally one that is consecrated by the venerable associations of antiquity, and exalting it to a position of exclusive value and exclusive authority over the religious life. The opposite extreme orignates in a similar misinterpretation of the fact, that no particular form of worship is the sole possible expression of the religious spirit. From this it is inferred that no form of worship is necessary at all. But neither conclusion follows from its premises, and neither is practicable in real life. For if the religious life is to be a reality, it must be realised in some form.

${ }^{1}$ Barclay's Apology, Proposition xi. 7.

${ }^{2}$ lbid. xi. 5. 


\section{THE CHRISTIAN CHURCH}

But, on the other hand, such are the varieties of spiritual life, that no particular form can be adapted for all men even at any one period, still less through all the changes that go on from age to age. In the private devotion of the individual it is not necessary, nor is it even possible, that forms should be rigidly fixed. There is often a gain to the devout spirit in being perfectly free to find expression in the form best adapted to the devotional mood of the moment. But there is also a gain, even to the individual, in the adoption of ready-made forms of expression for quickening his spiritual acts, like the other actions of his life, by fixed rules of conduct. But the necessity of fixed rules and fixed forms becomes unquestionably evident for social worship. Social life of any kind is possible only by rules which embody a common understanding among men. It might be pleaded that religion is exceptionally subjective, exceptionally individual, and that therefore it is better left entirely to the indivdual soul. Such a plea is not without an appearance of plausibility. For in regard to the rights as well as the obligations of the individual a wide scope must be allowed to the solitary communings of his own spirit with God. But the advantages of such spiritual solitude presuppose a certain maturity of religious life; and that maturity is reached through innumerable stimulations of social religion, while without these the new life might never be born at all, or might remain for ever stunted in its growth. In any case there is no more reason why social influences should be lost for religion than for any other cause in which the interests of humanity are at stake. But if those influences are to be won for religion, there must be religious institutions and laws or customs to secure united action.

(1) First of all, it is obvious that, if there is to be any kind of association in religious life at all, men must 
meet for religious purposes. The fact is, and it is extremely significant in this connection, that the original name of the Church was simply the word which the Greeks commonly used for their assemblies. ${ }^{1}$ It is also a significant fact that even the Society of Friends recognises this fundamental requirement of social religion. Barclay puts the point very sensibly. "To mect together," he says, "we think necessary for the people of Grod, because, so long as we are clothed with this outward tabernacle, there is a necessity to the entertaining of a joint and visible fellowship, and bearing of an outward testimony for God, and seeing the faces of one another." 2

(2) But the necessity of meeting involves still further the necessity of agreement as to the times of meeting. Here again we come into contact with the problems of Dogmatics and Church History in regard to the institution of the Lord's Day ${ }^{3}$ and other holy days of the Christian year. But our problem is purely ethical. It arises out of our obligation to agree with one another as to the most convenient time of meeting for religious edification. For the practical purpose of such agreement the historical point of view is eminently reasonable, as it neither includes nor excludes any theory with regard to the nature or origin of holy days. As a fact in history we find the Lord's Day and a few other festivals sanctioned by an almost universal custom in Christendom reaching back into a very early period. The arrange-

1 'E $\kappa \kappa \lambda \eta \sigma i a$ is still retained by the Latin races, as in the French église, Italian chiesa. How the Teutonic races came to adopt the word represented by church, kirk, kirche, etc., has not been satisfaetorily explained. The origin is most probably to be found in kvpiakbs, but the listory of its adoption by the Gothic Christians is very obseure. Trench, in his Study of Words (Lecture Iv.), gives the common account.

2 Barclay's Apology, xi. 3.

${ }^{3}$ It is well to bear in nind that this mame for the first day of the week, $\dot{\eta} \kappa v \rho t a \kappa \grave{\eta} \dot{\eta} \mu t \rho a$, has New Testament sanction (Rev. i. 10). 
ments of social as well as ecclesiastical life in all Christian eountries are made to harmonise with this eustom. By the Providence which rules through history there is thus at our disposal an admirable eonvenience for religious meetings; and it is difficult to see how, even if there were no dogmatie ground for the institution of the Lord's Day, we can evade the moral obligation to make use of the beneficent opportunities whieh it puts within our reaeh. Here again there is some interest in citing the singularly sensible attitude adopted by Barclay. After observing that "we know no moral obligation, by the fourth command or elsewhere, to keep the first day of the week more than any other, or any holiness inherent in it," he goes on to explain further- " But, first, forasmuch as it is neeessary that there be some time set apart for the saints to meet together to wait upon God; and that, sccondly, it is fit at some times they be freed from their outward affairs; and that, thirdly, reason and equity doth allow that servants and beasts have some time allowed them to be eased from their continual labour; and that, fourthly, it appears that the apostles and primitive Christians did use the first day of the week for these purposes; we find ourselves sufficiently moved for these causes to do so also without superstitiously straining the Scriptures for another reason." 1

4. In regard to the days and hours set apart for spiritual discipline, and the religious exereises to which these may be devoted, it is important to be reminded once more that these are useless, and even tend to be worse than useless, if they are not honestly made to serve the purpose for which they are designed. And

${ }^{1}$ Apology, xi. 4. Barclay appeals to Calvin in refence of his attitude. He gives, in fact, a brief exposition, in milder language, of the doctrine enforced in Calvin's exposition of the fourth commandment (Institutio, ii. 8 . $28-34$ ). 
this brings us, in concluding, back to the conception of the Church as in its essential nature an organisation for spiritual purposes. To keep the Church true to its ideal, it must be spiritual in practice as well as in theory. The only methods which it may employ are those which appeal to the spirits of men. It dare not, without treason to its lofty mission, condescend upon the methods $>$ of physical compulsion, which are legitimate within the power of the State. Our Lord's own instruction is that the new society which He eame to found upon earth is different in its nature from a secular State; it is a kingdom which is not of this world. ${ }^{1}$ The essential differentiation, also, of the function of the Church from that of the State is indicated in another familiar instruction, to render unto Casar the things that are Cæesar's, to God the things that are God's. ${ }^{2}$

This truth it is important to enforce on account of that confusion, which was referred to above, between the social functions of family and State and Church. This confusion characterises not only primitive society. It may be traced through all the higher civilisations as well. Even Christian civilisation has been continuously retarded by its influence. During the first three centuries, indeed, the Church was of necessity differentiated absolutely from the State. But even at that early period an impatient eagerness to accelerate the slow process of genuine spiritual growth appeared in the stern methods of discipline which were adopted by the Church to maintain its purity. So early as the time of St. Paul the severity of discipline had to be checked by his kindly wisdom advising the Christians of Corinth to forgive and even comfort an offender, "lest perhaps such a one should be swallowed up of overmuch sorrow." ${ }^{3}$ It is

1 John xviii. 36 .

2 Matt. xxii. 21.

${ }^{3} 2$ Cor. ii. 7 ; ef. Ps. xl. 12 . See above, p. 166. 
also a faniliar fact in history that the system of Indulgences, which wrought such havoc on the spiritual life of later times, originated out of necessities created by the cxcessive severity of disciplinary penalties in the early Church. ${ }^{1}$ But the worst effects of the confusion between the functions of Church and State arose after the conversion of the Roman Empire. Gradually the profession of Christianity was made a law of the State, and any departure from the orthodox form of its doctrines came to be treated as a crime. It is worth noting, indeed, that even in the deepest darkness of this hideous confusion the light of the truth was not wholly extinguished. For the Church court, the Inquisition, professed at least merely the spiritual function of inquiring into the doctrine of any one accused. On finding him guilty of holding illegal opinions it did not itself proceed to pronounce any sentence inflicting temporal, bodily penalties. In a phrase which sounds now like a grim hypocritical mockery, it "handed the offender over to the secular arm."

Unfortunately the Reformation did not deliver the Church from the appalling cruelty of persecution. In spite of the noble teaching of some of the Reformed confessions, that God alone is Lord of the conscience, in Protestant countries generally the representatives of the dominant creed endeavoured for some generations to force it upon the consciences of dissenters by methods of legal compulsion. They even retained the horrid barbarity of burning heretics at the stake. Only in comparatively recent times has dissent been gradually

1 The development of the doctrine of Indulgences can be studied in any work on the History of Dogmas. See, c.g., Harnack's, vol. vi. pp. 259-269 (Eng. trans.). Ullmann gives all elaborate sketch in Reformers before the Reformation, vol. i. p1. 217-234 (Eng. trans.). On the practice of the Church, Chetham's article in Smith's Dictionary of Christian Antiquities is valuable. 
released from civil disability, and there are in Christendom still some nations that inflict upon dissenters indignities which are a disgrace to Christian civilisation. Even in countries which have attained the utmost religious liberty the Churches appear at times to despair of the methods of spiritual conviction which are alone available for them. They are therefore tempted to call in the aid of legislation with its rude instruments in police force in order to grasp prematurely the ends which can never be secured but by the lordship of spiritual conviction over the lives of men. All this impatience is but the spirit of the querulous demand, "Where is the promise of His coming?" The evolution that is really going on in the kingdom of God is, from the very vastness of the process, hidden from the feeble vision of many who sink into the gloomy illusion that "all things continue as they were from the beginning of the creation." With intelligence too narrow to grasp the fact that "one day is with the Lord as a thousand years, and a thousand years as one day," their sympathies also become so narrowed that they cannot realise the long-suffering which does "not wish that any should perish" by haste in the infliction of punishment, but rather that " all should come to repentance." 1

With the renunciation of methods which call for physical compulsion the Church must also abandon a rigid uniformity of order and discipline which takes inadequate account of the infinite variety that must characterise the freedom of moral and spiritual life. The order and discipline of the Church must leave scope for the varieties of character among men who, as contemporaries, are obliged to live and work together, and it must also provide for that incessant change of external and internal conditions which forms a conspicuous feature 
of human existence. No dogmatic creed, for example, can be regarded as truly Christian which raises any barrier against members of the Church accepting new discoveries by which human life is being enriched , through the progress of genuine knowledge. Nor can any order of Church government or of Church service ignore, without folly and injustice, the improved methods which such discoveries suggest. The art of printing alone, and especially the recent cheapening of its processes, have placed in the hands of the Church means of a moral and religious instruction which was in former times attainable only by the oral teaching of her ministers. Undoubtedly an increasing number of genuine Christians find their spiritual culture in religious literature rather than in the oratory of the pulpit, and it would be a source of unmitigated regret if the Church refused their co-operation in Christian work because they do not find that regular attendance on her ministrations is necessary or even helpful to edification. 


\section{CHAPTER III}

\section{THE CHRISTIAN FAMILY}

Tue family as a social institution offers various phases for study. The variety of its forms at different stages of civilisation has been made the subject of extensive and fruitful research, especially in recent times. But such investigations lie beyond the scope of our inquiry, except in so far as they may incidentally throw light upon it at times. ${ }^{1}$ It is the Christian family alone that concerns us here, and even that is viewed only in its ethical aspect. Our subject is even narrowed down to the Christian family of our time. We do not, for example, require to go back to a period when slavery was still an almost universal feature of family life, and the relations , of master and slave formed no unimportant part of Christian morality. ${ }^{2}$

The distinctive feature of the family as a social organisation is the fact that it grows out of relations that are formed irreversibly by nature. On their physical side these relations eonstitute what are commonly spokeu

1 The elaborate work of Westermarck, The History of Human Marriage (Maemillan \& Co.), contains full information on the subjest with ample reference to its literature.

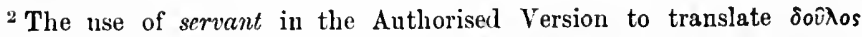
unfortunately leads still to the adoption of passages about masters and slaves as texts for sermons on the duties of employers and employees in modern life. It is diffieult to say whieh party is most injured by the mistake. If the nne is treated as a slave, the other is put in the position of a slave-holder. 
of as natural or blood-relationship oi kindred. On their mental side they appear in the form of those emotions which are distinguished as the natural affections. To understand the ethical significance of the family, it must be borne in mind that an affection which is purely natural is not yet, as such, moral. To repeat a distinction already drawn, it may create good nature in a man, but it is not in itself good will. Accordingly the sentiment of natural affection requires to be refined into a corresponding moral sentiment. But such a sentiment can only be the fruit of moral training, and the training which bears such fruit is twofold. It is, on one side, a discipline of moral intelligence in recognising the obligations which arise from the relationships of family life. On another side, it is a ceaseless discipline of the will, forcing it to observe these obligations in all the little incidents which make up the daily intercourse of a family.

There are three relations which give rise to three different spheres of duty in the family. These are the relations (1) of husband and wife, (2) of parent and child, (3) of brothers and sisters.

\section{$\S 1$. The Conjugal Relation}

The conjugal relation, though it must take its origin beyond the limits of all the closer natural relationships, yet owes that origin to one of the most powerful instincts in man's emotional nature. But a conjugal relation, a marriage, which is sanctioned by Christian Ethics, requires that the instinctive sexual affection out of which it originates shall be elevated into the moral sentiment of conjugal love. That is to say, it must be purified and fortified by the force of moral volition, by the mutual resolve of the man and the woman to love 
one another. This mutual resolve has therefore been always regarded as the foundation on which Christian marriage must rest. "Mutuus consensus conjugum est causa efficiens matrimonii," is a common formula of the old divines. Any union of the sexes without this spiritual and moral sanction is inconsistent with civilised morality in general, but is peculiarly repulsive to Christian sentiment in particular. There is perhaps no point in social morality in regard to which the demand of Christian sentiment has been so exacting. That demand has rigidly restricted legitimate union within the bond of matrimony. While noble sentiments in favour of purity, in detestation of sensuality, may be met with elsewhere, no great civilisation outside of Christendom has ever been so rigid in this region of the moral life. This rigidity is all the more remarkable from its contrast with the dark environment of hideous laxity amid which Christianity first spread. The necessity of enforcing this contrast seems an obvious explanation of the extreme view to which most of the early Christian moralists were driven. At all events, under the circumstances, it is not unintelligible that many should have come to regard a natural appetite, which was the source of revolting sin, as being evil in its very essence, to make the conquest of this appetite an essential feature of the perfect life, and thus to exalt virginity into the highest rank among the virtues.

This excess of reaction against a prevalent licentiousness, though far from inexplicable, was singularly unᄀ fortunate for healthy morality. Logically, it involves a system of thought which, setting at defiance an ineradicable fact in the nature of man, is essentially irreligious. So far as it has invaded the ethical theory, as distinguished from the ethical practice, of Christendom, it may not improbably be traced to the influence of 
Stoicism on the early Christian moralists. Stoicism, as we have seen, held that the whole emotional nature of man is essentially irrational, and that therefore in a rational life it must be completely suppressed. As was the attitude of the Stoics towards emotional excitements in general, such was the attitude of the early Christian moralists towards sexual emotion in particular. Both stood in irreconcilable contradiction with the faith, to which both were attached, in the divine origin of nature. Accordingly every wise practicable scheme for the cultivation of purity must be based on a frank recognition of the fact that the emotional impulse to be controlled forms an integral factor of the divinely created nature of man, and, as such, claims its legitimate gratification.

It is this sane view of fact, even in presence of the loftiest idealism with regard to marriage, that finds expression in the teaching of Jesus. In the spirit of what is now called the higher criticism, He goes beyond $r$ Mosaic legislation, insisting even that that legislation must be set aside when it comes into eonflict with the older legislation which is revealed in the purpose of the Creator as embodied in human nature. He points to the fact that in the ereative plan human beings are differentiated into male and female, and that therefore, in fulfilment of that plan, they must be prepared to break off from the primary union with their parents in order to form a new union as man and wife. ${ }^{1}$ In this teaching there is no hint of any unnatural perversion of moral sentiment. Such a perversion indeed did begin to corrupt the healthy moral sentiment of the Church even in New Testament times, and it was then met by that appeal to the facts of nature as revealing the will of God, for which Christ had created a precedent in His

${ }^{1}$ Matt. xix. 3-5 ; Mark x. 2-7. 
teaching. In the first of the pastoral Epistles a heresy is denounced, in very strong language, as "forbidding to marry" and imposing other artificial restrictions on the natural appetites of men. In opposition to all this futile defiance of nature the apostle declares, with clear moral insight, that everything created for our use is in itself good, and therefore not to be refused, if it is aceepted in a grateful spirit. ${ }^{1}$

At a later period the spurious ascetieism which had been rejected by the apostles spread to an astounding cxtent throughout the Church, though in its most offensive forms it continued to be associated with heretical sects. $^{2}$ The later views of Christian moralists on this subject seem to have been influenced not only by the general asceticism of Stoical theory, but by its special attitude in reference to marriage. For, while reeognising and recommending marriage in a general way as a necessary social institution, Stoical teaching could not avoid indicating that the celibate life is more favourable to that apathy and self-sufficient independenee which were regarded as essential to perfect virtue. The truth is, that Christian noralists, like the Stoical, became thus entangled in doctrines which are logically subversive of one another. For, on the one hand, an unscientific asceticism led them to exalt into a virtue of the perfect life a practice which would inevitably bring about the extinction of the human raee with all its virtues, and in any case would leave its propagation to beings with all the hereditary defects of an inferior moral type; while, on the other hand, they were obliged to recognise that, in order to the continuanee of the superior virtue itself, it had to be renounced. But, on the whole, in spite of

${ }^{1} 1$ Tim. iv. 1-5.

2 The earliest indications of this are traced by Dobschiitz in the Urchristlichen Gemeinden, 1'I. 183-184. 
this antinomy of moral judgment, the catholic doctrine of the Church has given to marriage the rank of a divine institution with a peculiar sacredness; though very properly it also contends that there are exceptional conditions, sometimes physical, sometimes spiritual, which may make the obligation of celibacy imperative. ${ }^{1}$

The peculiar sacredness ascribed to marriage by Christian moralists forms, in fact, one of the most distinctive features in the social Ethics of Christianity. This sacredness attained a characteristic formulation in the doctrine which ranks marriage among the sacraments of the Church. We need not here be drawn into controversy about the technical application of the term sacrament. Apart altogether from this problem of terminology, the doctrine in question points to a peculiar consecration which marriage has reached in Christian Ethics. As already indicated, indeed, all the higher civilisations, founding on a patriarchal type of society, have necessarily imparted a bigh importance to marriage and the family which it creates. But it may safely be

${ }^{1}$ Even at the present day Roman Catholic teaching remains entangled in the old antinomy. It is very pronounced in the admirable text-bookthe Summa Philosophica- of Cardinal Zigliara. See vol. iii. pp. 200-203. The author admits that marriage is ordained for the perfection of the race, that is, the conservation of society. But he contends that it is not directly ordained for the perfection of the individual; and therefore it cloes not constitute any obligation for him, unless it were to happen that "without his marriage the human race would become extinct." Consequently, as the celibate can devote himself more fully to intellectnal and moral perfection than those who are eneumbered by family ties, celibacy is more exeellent than matrimony for the sake of society as well as of the individual. The whole discussion of the Cardinal, not to speak of some remarkable specific assertions, is apt to suggest the query, whether it is not a solecism in justice that the eanon law in regard to marriage should have been left to the development and administration of men who, by the most solemn vow, are debarred from learning, either by experience or even by sympathetic imagination, the spiritual culture or any
of the other boons of wedded life. 
said that no civilisation has ever given to marriage the sacred import with which it has been invested in Christian teaching. And this teaching can be traced, perhaps more clearly than any other doctrine in the compass of Christian Theology, to the very pronounced utterances of the Master Himself.

It has often been said, and with truth, that Jesus was not a social reformer in the common sense of the term. $\rightarrow$ He did indeed aim at social reform, and that of a very thorough character; but it was a reform to be brought about, not by new-modelling the institutions of society, but rather by regenerating the moral character of men. Consequently, profound as may be the social changes resulting from such a regeneration, Jesus proposes no sort of political revolution, offers no programme for the reorganisation of society. But there is one point at which He departs from His general policy of avoiding interference with the external institutions of society, and that is the institution of marriage. On this point His teaching is unique-unique to a degree that is startling to the historical student; for it diverges substantially from the practice and theory of the whole world, even of His own country. It stands in special contrast with the prevalent laxity of $\mathrm{His}$ own time. That laxity was recognised by great pagan teachers as eating into the very vitals of family life, while Jewish rabbis sometimes went beyond any moralists of the Gentile world in relaxing the marriage-bond. Even Hillel, from whose school probably a large proportion of the primitive Christians were drawn, in his interpretation of the marriage law, advocated a loosening of its obligations which could scarcely be equalled by the most facile of divorce courts. To this whole trend of thought and practice Jesus stands in unqualified antagonism. For Him marriage is a bond which admits of no relaxation. 
It is true that, in one version of His teaching, adultery is specified as a legitimate ground of divorce. ${ }^{1}$ To some critics this appears a qualification by some later editor, seeking to obviate the offence created by the stringency of the original teaching. By other critics the omission of this exception ${ }^{2}$ is regarded merely as implying that adultery was taken to be itself a dissolution of the marriage tie, and as therefore requiring no explicit specification. The dispute is of minor importance. Even if the act of adultery constitutes divorce by its very nature, the teaching of Jesus remains, that the man or wife who enters into a new marriage under any other condition, puts himself or herself morally in the rank of an adulterer. No such indissolubility had ever been attached to the marriage bond before. No wonder, thercfore, that even the disciples staggered at the unexpected rigidity of the Master's teaching. "If," they say, "the case of the man be so with his wife, it is not expedient to marry." 3

There are three features thus given to the Ethics of marriage by the teaching of Christ Himself. (1) Sexual affection is an integral factor of human nature as planned by the Creator, and its full gratification is as legitimate as that of any other natural feeling, though only within the general limits of moral law and the special limits of wedded life. (2) Marriage and the family are necessary institutions of society, and consequently Christian Ethics

1 Matt. v. 32, xix. 9.

2 In Mark x. 11-12 and Luke xvi. 18.

${ }^{3}$ Matt. xix. 10. It is perhaps of some critical significance that Matthew, the only evangelist who qualifies the Master's teaching, is also the only one who mentions the grumbling of the disciples. In the work of Professor Peabody of Harvard, Jesus Christ and the Social Question, ch. iii., on the Tcaching of Jesus concerning the Family, is pecnliarly valuable, not only for the general drift of the teaching of Jcsus on the subject, but morc partienlarly for its hearing on the marriage problems of the present day, especially in the United States. 
is irreconcilably opposed to all schemes of social reconstruction, by which those institutions would be eliminated. (3) Marriage is no common contract which can be set aside by the desire of one or even of both of the contracting parties; it is a bond which is indissoluble during earthly life, except by a cause which may be taken to be in its very nature a dissolution.

Objections to the practical indissolubility of the marriage-contract arise, in large measure, from ignoring obvious facts in the natural as well as in the moral life of man. It is continually forgotten that the love of man and wife, to be abiding, must be not merely an instinctive impulse of nature, but a cultured moral sentiment. However passionate the natural attraction of the two to one another may be at first, its continuance is not to be expected. It is true a reflection of its glorious dawn often illuminates with a milder halo even the latest evening of a long married life. But it is not the glory of the dawn itself. It is indeed the purest element of the primitive love. It is that part which was something more than a blind unreasoning instinct, which had its origin in an intelligent regard for each other's character and in an intelligent resolve to live for each other's welfare. Such an intelligent affection may not only endure through all the changes of life, but may even gain force from the increasing knowledge which man and wife acquire of each other's worth. On the other hand, the instinctive affection depends on physical conditions which vary even with the varying incidents of daily life, and disappear altogether with young manhood and young womanhood. It is therefore extremely disastrous to rest the welfare of a home on the continuance of such a transitory instinct. As it begins to cool with advancing years, or even at any early period amid the manifold distracting interests of life, an illusion is apt to 
be created that conjugal affection has become extinct. Those who experience such a change are apt to yield to this illusion instead of endeavouring to replace the evanescent passion of youth by the trained habit of maturer years. The result is that they often sink into the conviction of despair, that marriage had been for them an irreparable failure; and either they seek a practical, if not a legal divorce, or they reconcile themselves to a fate which is even harder to bear, a separation in spirit while they have to face daily association in external life.

When conjugal affection is thus conceived, not as a variable impulse of emotional nature, but as a habit of rational will, the eontract of fidelity in marriage loses the appearance of irrationality, with which it has sometimes been charged. It is no longer an irrational promise to do what is beyoud the power of human will, to prolong an efflorescence of sentiment which must pass away with the process of natural growth as inevitably as the flower withers to make way for the fruit. It becomes the free act of intelligent beings solemnly legis- $v$ lating for the government of their own lives. And it is well to bear in mind that all that is valuable in human life is attained by elevating it above the capricious moods of emotional nature into the dominion of a rational order. ${ }^{1}$

1 In Carlyle's essay on Diderot (Essays, vol. iv. pp. 233-234, ed. 1857) there is a noble exposition of this theme as a protest against the French philosopher's singularly shallow interpretation of the mcaning of marriage. In this conneetion it is worth while to observe that the names Ethies and Morals are derived from words that denote the habits which form the character of individuals, the custons which form the character of nations, and that these words express rarlically the idea of what is fixed in eontrast with what is variable in life. Thus $\hat{\eta} \theta$ os and $\varepsilon^{\prime} \theta$ os, which scem merely dialectical varieties of one word, are connected with the root of

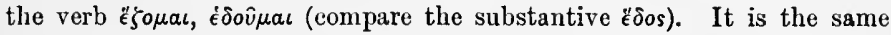
root that we find in the Latin sedeo, the English set and sit, the German setwen and sitzen. Consequently the Gorman sitte is not only the equi- 


\section{§ 2. The Parental and Filial Relation}

The natural relationship of parents and children has, of course, two sides, creating two types of natural affection and two corresponding types of duty in family life, parental and filial.

1. The parental mind assumes properly the tone of authority, but of authority mellowed by affeetion. This is the natural attitude of the parent; but, like other facts in human nature, it must be regulated and inspired by Christian love. For the authority of parent is not absolute. It is restrieted, on the one hand, by their own duty of loving regard for the welfare of their children; on the other hand, by the fact that a certain sphere of liberty belongs to a child as a moral being, though in an undeveloped state. The respective limits of parental authority and filial liberty it is not always easy to determine. They must be adjusted from time to time in accordance with the growing claims of childhood by the intelligent taet of a Christian love. In the enforcement of authority the main precaution of the parent is to make sure that the demand, upon which he authoritatively insists is in harmony with Christian morality. There can be little doubt that, if such a demand is enforced with parental dignity and affection, its reasonableness

valent of $\hat{\eta} \theta$ os in meaning, but allied to it in etymology ; and sittenlehre should represent Ethics exactly. The worl $\theta \dot{\epsilon} \mu \mathrm{s}$ also has the same root, $\theta \epsilon$, which is found in $\tau\{\theta \eta \mu \iota$, so that it deseribes law as something settled or established. It is worth noting, further, that the substantive wont (German Gevolnheit) conveys the same idea originally, as it is connected with the old English verb von (German wohnen), meaning to dwell. The greatest poet of Rome, who had a very lofty conception of the part which his country had played in civilisation, deseribes its primitive inlabitants as a people "quis neque mos neque eultus erat" (AEneid, viii. 316), while Jupiter promises for it the mission: "Moresque viris et menia ponet" (ibid. i. 264). Conington's notes on the full meaning of mores are interesting. 
will in the long run win the assent 'of the child. But no principle of Christian Ethics can warrant the enforcement of an unreasonable demand, or even the enforcement of a reasonable demand by methods that are incompatible with the dignity and affection which a parent ought to maintain. For the supreme obligation of a parent, as a parent, is love for his children; and that love, if it is something more than a blind impulse, if it is a moral habit, means an intelligent regard for their highest well-being. Consequently the Christian parent will make it the dominant aim of his family arrangements to train his children to the highest Christian life. Whatever stimulants of the religious spirit nay be found elsewhere, in church, in school, in companionship, the home will always remain the most potent and constant sphere of religious culture. The chief influence for such a culture must of necessity proceed from the parents. It is true, the innumerable tender graces of childhood will react on the susceptible father and mother, and reward them with an expansion of spiritual life which is far more than a compensation for all parental labour and care. But this reward of parents can be enjoyed in its fulness only by those who have loyally endeavoured to "bring up their children in the nurture and admonition of the Lord." ${ }^{1}$ It is an occasional complaint of the present day, that the Sunday school is supplanting the home school, and relaxing the sense of the obligation resting on father and mother to give personal attention to the religious training of their children. To what extent this complaint is founded on fact need not be discussed here. It would probably be difficult to prove that, where parental laxity exists, it is in any way due to the Sunday school. But it would certainly be a great disaster for the spiritual life of the 1 Ejh. vi. 4. 
home if there were any weakening of the duty of parents to educate their children, by example as well as by precept, to the highest ideals of Christian morality.

2. It is by such education that the other side of domestic virtue is realised, - that which arises from the relation of child to parent. As the parental mind takes a tone of authority mellowed by affection, so in the child-mind the tone of affection is modified by respect. It is this complex sentiment of respectful affection that is understood by filial love. This is also included among the so-called natural affections. That is to say, it tends to grow up under the varied influences of the natural relation between child and parent. But its permanence and proper direction can be secured only by moral culture; and therefore the culture of filial love ought to be, in the first place, an object of parental care, and then an object of the child's own endeavour as soon as he can be made to realise the necessity of moral training. It is by this culture that the child acquires one of the most valuable moral qualities, the habitual sentiment of reverence for authority. This sentiment is indispensable both for individual and social well-being.

(1) In the individual it forms the foundation of moral character. There can be no genuine morality without a sense of reverential awe before the majesty of the imperative ougur; but with this sense strongly developed the moral character is always safe. The time for the development of this moral sense is obviously that early period during which childhood remains dependent on parental love and care. If revcrence for authority is not developed before young manhood and womanhood attain a consciousness of personal independence and manifest naturally a self-assertive claim for freedom, it is hardly probable that the sentiment will be developed at all in strength adequate to mould the moral life. 
(2) But if reverence is the essential foundation of moral character in the individual, it is equally essential to social stability. The only secure safeguard of any society is a general sentiment of loyal respect for the institutions and laws which constitute its social order. Without that any political union must fall into irremediable disintegration. But this sentiment of respect for a higher authority can become an energetic and permanent force in national character only when it is woven into the very fibre of individual character by habitual early training, and this result can be attained only by calling into habitual play in the home that filial affection which is a combination of reverence and love. The peculiar promise, therefore, which is attached to the fifth commandment in the Decalogne, is based on a sound psychology, confirmed by historical experience. The days of a nation's independent existence must be numbered by proportion to the thoroughness with which its citizens have been trained in childhood to honour their father and their mother.

\section{§ 3. Tife Relation of Brother and Sister}

The remaining relation of family life is that of the children to one another, the relation of brothers and sisters. Wo lack a single collective term, like the German Gcschwister, to denote the members of this relation; and the lack is felt also in the want of a convenient expression to represent the German Geschwisterliebe, the affection felt for each other by the ehildren of one family. Brotherly love is the phrase nearest to it in our language; but it is far from being its equivalent, as it is most commonly applied to those general affections beyond the linits of kindred, which resemble in their intensity the natural affection of brotherhood. 
With regard to the moral relations of brothers and sisters, little remains to be said in addition to what has been already indicated in connection with the other relations of family life. Here again natural affection forms, of course, a powerful impulse to the will; but it must not be taken for the moral habit of loving, which has to be trained by brothers and sisters subjecting themselves to daily discipline in doing deeds of brotherly and sisterly kindness for one another. Such a loving habit is fostered under peculiarly favourable conditions. Rooted in the kindly soil of a deep natural affection, it continues to draw perpetual nourishment from the same rich source. It thus rises with comparative ease into the highest region of social morality, - that region in which there is no hard bargaining about the good to be given or received, no hesitating delay about conferring a benefit till a full equivalent is guaranteed; but under the stimulus of natural and cultured affection goodwill overflows in constant streams which bless giver as well as receiver. It is for this reason that brotherly love has come to be taken by the human mind as a type of the finest friendship that can be realised by men in general. For the same reason, when human beings associate for any of the more serious purposes of life and seek to maintain a finer moral relation with one another, they readily describe their association as a brotherhood or sisterhood, and its members speak of each other as brothers or sisters. This idea has beeome specially familiar to the Christian mind from its frequent occurrence in the New Testament. The ideal relation, into which Christians enter with one another is described under the figures of family life. They are spoken of as being all brethren, children of one Father in heaven.

There is one preeantion in the intereourse of family life which is peeuliarly important to protect its finer 
fruits from being blighted. Brothers and sisters are not only allowed, but even required, to show to one another a kindly familiarity of language and manner, which would in general be offensive towards strangers. In their intercourse with one another, therefore, one side of their emotional nature is freed from a restraint which must be rigidly maintained in their intercourse with other people. But this relaxation of emotional restraint is apt to be perilously extended. The freedom, which is legitimately given to the delightful expressions of kindly feeling, is often yielded as freely to unkindly explosions of an irritable temper. The result is that the moral refinement of a home may be destroyed, its life more or less completely vulgarised, by a lack of those courtesics without which the finer moralities of life ean never be permanently sustained. This rudeness in family relations is far from uncommon among brothers and sisters who are ready to don the dress of eonventional etiquette whenever it is required for display in general society. That is, of course, no genuine courtesy which is put off and on like an external elothing. Genuine courtesy must flow from a "soul of courtesy," forming an habitual feature of personal eharacter, and regulating conduct in all the relations of life. If any distinction is to be drawn in regard to the manners and language which ought to be used in different relations of life, surely the sphere from which every approach to rudeness should be rigorously exeluded, the sphere in which the finest courtesies should be uniformly maintained, is the home. 


\section{CHAPTER IV}

\section{THE CHRISTIAN STATE}

An ideal society must be one after the type of the Church. As we have seen, the Church is a social organisation governed by purely spiritual motives. Its code of laws is one demanding only the voluntary assent of its members. It cannot, without contradicting its essential nature, allow any kind of external compulsion to enforce obedience. In the family also, as we have seen, social relations are governed by those kindly sentiments which originate in kinship and attain their finest efflorescence under the culture of Christian goodwill.

Such are the ideals at which all social development should aim, and towards which apparently all social development is actually tending. But while the imperfect condition of human nature makes the realisation of such an ideal impossible, what is to be done? Bare existence, and still more such an existence as can truly be called human, demand for their very possibility certain external conditions. Without these the family and the Church become themselves impossible. It is to secure these external conditions of human life that the State primarily exists; and as these are indispensable, the State can fulfil its functions only by being endowed with authority and power to enforce those conditions when they are not conceded by voluntary assent.

This, therefore, forms the distinctive feature of the 
State as a social organisation, differentiating it specially from the Church; and in the interests of both it is of infinite importance that the differentiation should be rigidly maintained. As it is a prime obligation of the Church to remain true to her spiritual character, so it becomes a prime obligation of the Christian State to limit its compulsory authority within the sphere in which alone compulsion is possible. It is thus debarred from attempting to control the spiritual life by the compulsory methods of persecution. An adequate physical force can indeed prevent or punish any physical action of men. It may therefore prevent or punish the expression of particular thoughts or feelings. But all the force of the physical universe cannot compel the spirit of man to think or feel in accordance with any fixed rule. Only spirit can act upon spirit; and all the interests of Christian civilisation demand that the human spirit should be left free to the influence of purely spiritual motives, and even motives of the highest ethical character. Persecution may indeed create a motive; it excites the fear of physical pain. But this emotion ranks among the lower motives of life; and an important part of moral culture, as we have seen, consists in winning that victory over fear which forms the cardinal virtue of courage.

The excessive interference of the State with the freedom of the individual, especially in his spiritual life, bas tended to create a reaction towards an opposite extreme which would not only curtail, but even abrogate, all compulsory authority. This reaction has in our time culminated in the political theory known as Anarchism. $\checkmark$ Such a theory would scarcely call for notice here, were it not for the fact that, among supporters like Count Tolstoi, it seeks a foundation in the teachings of our Lord. Nor does the theory claim notice here as a speculative dogma; but it bears upon the practical life of the 
Christian, and in that respect it comes within the domain of Christian Ethics. We have already touched upon some of the instructions in the Sermon on the Mount against resisting the wrong-doer, upon which this amiable type of Anarchism founds. ${ }^{1}$ We have also pointed out what seems to be their true interpretatior. The Anarchistic interpretation is surely a very prosaic rendering of Oriental figures, which are far from unintelligible to the coolest Western imagination. Certainly the apostles never dreamt of their Master's teaching being in any way hostile to the authority of the State as an ordinance of God for the well-being of man. ${ }^{2}$ The whole attitude, moreover, of the early Church was designed to vindicate the spiritual freedom it claimed against any suspicion of disloyalty to the legitimate demands of the State. Nor has the higher moral intelligence of the world ever denied the right and even the duty to prevent wrong, wherever possible, by the $\checkmark$ use of adequate physical force. It is quite true that the individual may often legitimately submit to the endurance of wrong in his own person, provided he does not thereby inflict wrong upon others. It may be admitted also that a more heroic courage is often displayed in the strength of quiet endurance than by rude methods of physical redress. But there is a limit even to righteous personal endurance; and a healthy morality - a morality which is the exponent of thoroughly sane manhood and womanhood-erects a more conspicnous limit to submission in the case of wrongs inflicted upon others. If a man of fair physical vigour is standing by while an outrage is being perpetrated on a child, on a woman, on a feebler man, and if he declines to interfere when he could prevent the

1 Above, pp. 93-95.

2 The classical passage on this theme is Rom. xiii. 1-7. 
wrong by his superior strength, if even he is not willing to stake his personal safety on the venture, it is hard to comprehend any casuistical dialectic which can absolve him from participation in the wrong. But if such resistance to evil is allowed and even demanded of the individual, much more does it come within the rights and obligations of an organised community acting in accordance with a reasonable constitution and reasonable laws. This becomes all the clearer when it is seen that the social order, which the State represents and enforces, is not an interference with individual liberty, but rather the condition under which alone individual liberty can be realised. For the function of the State is to secure 2 the liberty of all its citizens. Now the liberty of all does indeed imply the right of each to act as he chooses. But this could not be the right of all unless each, in acting as he chooses, refrains from interfering with the same right on the part of any other. It is equal liberty for all $\downarrow$ in this sense that the State is designed to guarantee.

In explaining the mutual obligations which thus arise, a distinction must be drawn between the moral and the political points of view. Sometimes political measures are advocated on the ground of their being in a special sense moral. But all legislation either is or is not moral according to the point of view from which it is described. For all legislation ought to aim at the moral well-being of the people for whom it is enacted. $\checkmark$ All legislation, however, is at best only a social regulation by which it is expected that moral well-being will be promoted. It is, therefore, a means to an end; but, as often happens, the same end may, under different conditions, be attained by different means. Accordingly in political life good men are often found to differ, not only in regard to the wisdom of particular measures, but even in general principles; and this produces the great 
lines of cleavage by which political parties are separated. To illustrate by a particular measure, temperance in the use of alcoholic liquors, as indeed in every other respect, forms an indispensable factor of moral well-being; but there is wide scope for difference of opinion as to the political measures by which this virtue may be most effectually promoted. No man, therefore, is to be stigmatised as indifferent, still less as hostile, to morality, who is opposed to a particular measure for the promotion of temperance or any other virtue. He may be convinced that some other measure would be more effective. He may even hold, in regard to some virtues or vices, that legislative interference is of no avail, and that the only effective method by which the moral ends of humanity can be attained is the training of moral intelligence and will. But, on the other hand, it is not to be assumed too readily that legislative enactments are ${ }^{\prime}$ of no value for the moral life of a people. It is quite true that "men cannot be made moral by Acts of Parliament." No regulation of external conduct by external compulsion can of itself develope those habits of internal life which constitute moral character. But external regulations may create social conditions which are favourable or unfavourable to virtue or to vice. That was therefore a wise saying ascribed to an ancient Pythagorean philosopher, who was asked by a father the best method of moral education for his son: "Make him citizen of a State with good laws." For the State with the legal code by which it is realised is, in a very real sense, a divine institution. ${ }^{1}$ It forms an organised embodiment of the highest revelation of God, that a

1 Tôे $\theta \epsilon o \hat{v} \delta$ sararý (Rom. xiii. 2). The student of philosophy may $\downarrow$ surmise that idealistic theories of the State are perhang merely expressions of the Pauline idea in the peculiar terminology of Ilealism, while he may also realise more clearly the meaning of the idealistic theories by translating them back into Pauline language. 
nation has been able to attain in its national life. Accordingly it becomes one of the primary obligations of the individual to the State to work for the improvement of its legal code. Every such improvement provides at least a more favourable social environment for a corresponding improvement in the moral life of the people.

Notwithstanding the lofty moral function with which the State is thus invested, there is a prevalent assumption that the highest morality is not demanded, or, if demanded, is not possible in political life. Baseless as this assumption is, its origin is not far to seek. Political life implies the co-operation of individuals and classes with varied characters and varied interests. The individual is thus accnstomed to recognise that, in order to the possibility of national action, he must make up his mind that he cannot always have his own way, he must give up his own preferences at times-in brief, he must compromise. How far is this legitimate? The question is not always easily answered. Legitimate compromise seems at times to be separated from illegitimate by no distinct line of demarcation. Men yield what they consider to be merely best among a number of competing alternatives that are all allowable; and, perhaps without being aware of the transition, they are led to yield what is imperatively demanded of right, and thereby to consent to what is wrong.

The politician thus accustoms himself at least to come down from the higher altitudes, to range on a lower level of the moral world. In this tendency he is perhaps confirmed by the unreasonable and impracticable obstinacy of the stickler for trifles, holding forth a living lesson of the unavoidable necessity of compromise if the work of the world is to be carried on at all. But the tendeney is aggravated by the interests of party being neeessarily 
intermingled, and by an unfortunate illusion often confounded with those of country.

This degradation of political life may be due at times to a mere lack of moral intelligence; but unfortunately $\checkmark$ it is often traceable rather to a corruption of will. The corrupt motive by which the will is seduced takes in general the form of bribery. Men bribe others or allow themselves to be bribed, not necessarily by money, but by various other tempting inducements, by playing, in fact, upon any of the numerous petty motives which wield power over human life. Every mode of corrupting trickery is ready to seek defence in the corresponding trickery of a casuistical dialectic. One of the commonest and coarsest forms of this dialectic meets us in the plea that it is necessary to "fight the devil with his own weapons." This is obviously a particular form of the general moral sophism, that it is allowable to use evil means in order to reach some good end. The plea is therefore liable to the condemnation pronounced upon it by St. Paul ; ${ }^{1}$ but it merits some special criticism from its own peculiar character. It is fortunate that St. Paul has anticipated this particular form of moral sophistry, and even in the very figure of speech in which it finds expression. "The weapons of our warfare," he says, "are not carnal." 2 But the most remarkable feature of his utterance is the reason which he gives for not resorting to such weapons. To the sophisticated mind it appears as if the spiritual weapons of candour and uprightness and generosity in the conduct of a political campaign are utterly impotent; and that is the reason why many are ready to snatch any other weapons that seem more likely to foree a way to victory. But to the practiser spiritual insight of the apostle it is carnal weapons - the weapons of the devil-that are 
powcrless. That is the reason why they can never form any part of the armour of the Christian; the weapons required for his warfare are "mighty through God to the pulling down of strongholds." 1

It is true that spiritual weapons will not always secure what is commonly understood by success, that is, success in external life. But no man is under anyv obligation to be successful in this sense. Such success depends not only on the voluntary efforts of individuals, but on the operation also of vast and complicated forces which are often beyond individual control. The utmost, therefore, that can be required of any man is to will what is right and leave the issue to the Ruler of the Universe, by whom all its agencies are controlled. If in a political contest the Christian succeeds in resisting all temptation to indulge in "corrupt practices," succeeds in keeping his Christian honour unstained, he has achieved success in the only sense in which success is imperatively demanded. He and his party may suffer political defeat. They may be defeated by a party that marches to power by trampling on many of the principles which are essential to Christian life. Such defeat is undoubtedly galling to some of the most natural and legitimate feelings of an honourable mind. But it requires no unusual keenness of spiritual insight to discern that a success, won by violating the eternal principles on which the universe is governed, is a defeat in the most tragic sense of the term. It is all the more tragic because of the illusion of victory by which its real character is concealed.

Nor is the defeat of the apparent victors merely a moral disaster in their individual lives. Such a disaster is appalling enough. But it often involves, besides, ruin to the cause of unrighteousness, with which it has been 12 Cor. x. 4. 
associated. For all evil is, in its essence, a disintegrating process. It carries in itself the principle of selfdestruction. Consequently the most effective method of completely getting rid of an evil is often that of leaving it to work out its own annihilation. At all events, in the temporary triumph of unrighteousness we may surely catch a glimpse of the larger wisdom characterising the cosmic process by which the moral world is ruled. As it is said that the darkest hour is the hour before dawn, so we can see why the hour of darkest gloom in the moral world may be, nay must be, that which precedes the sunrise of a brilliant spiritual day. That is a truly prophetic note which the old singer of Israel has struck in one of the psalms: "When the wicked spring as the grass, and when all the workers of iniquity do flourish, it is that they shall be destroyed for ever." 1 Nor in the depression of his defeat, amid the irritating huzzas of his triumphant opponents, should the Christian forget the inspiring consolation he may draw from the results of a defeat far more overwhelming in appenrance than his own. On that first Good Friday in the history of our race, the cause, which was more elosely identified with the cause of righteousness for the world than any other can ever be, seemed to go down in disaster more irretrievable than any cause has ever sustained. And yet it is but a sober historical fact, that that defeat was the most triumphant victory in the moral warfare of the world. The spiritual civilisation of all the higher races of mankind

${ }^{1}$ Ps. xcii. 7. Claudian (In Rufinum, i. 21-23) strikes a similar note :

"Jam non ad culmina rerum

Injustos crevisse queror. Tolluntur in altum Ut lapsu graviore ruant."

Aristotle has also expressed the idea in his brief, pithy prose: Td $\gamma \dot{d} \rho$

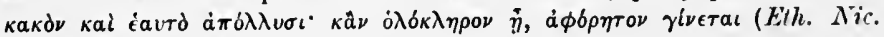
iv. 5. 7). 
draws its most potent inspiration still from the infinite spiritual force of the victory won through that defeat.

To the inspiration of this victory an additional energy is given by the earlier victory of the Temptation. The third of the temptations of Christ was such a bribe as has often appealed to the powerful minds of the human race. The glory of an empire over the kingdoms of the world has been offered again and again on condition that it should be won by doing homage to the devil, by fighting under his banner, with his weapons, in a word, by being not over-scrupulous about the means to be employed for the imperial end ; and many of those whose figures stand out conspicuously on the field of history have accepted the devil's terms, dazzled by the bauble of a dominion gained by ruthless brutality in war or by unscrupulous diplomatic trickery. Yet, after all, there is but one Lord of the universe; and if we do not worship Him willingly, we have to serve Him and work out His purposes against our will.

Of political existence, still more of political well-being, industry is an essential factor. The maintenance of the State depends on its economy. Political economy, therefore, is not an independent science. Properly it forms part of the general science of Politics. By the very ctymology of its name, Political Economy is a regulation of the national houschold.

But in regard to the bearing of Christian Ethics on industrial problems it is essential to remember again that the aim of Jesus was not primarily any external recon- $v$ struction of social order. His teaching, indeed, must affect the organisation of industry as well as of other features in the structure of society. But, as we have seen, His aim was primarily a moral regeneration of men; and that will construct for itself such industrial arrangements as may form its fittest embodiment. The 
effect of moral regeneration on industrial life cannot be fully understood, except by a detailed analysis of the complicated phenomena of modern industry. This, of course, is beyond the scope of a general treatise on Christian Ethics, though it might well form one of the most important monographs within the field of the science. ${ }^{1}$ Here we are limited to the main principles of Christian morality in application to industrial problems.

At the outset it is worth observing that the teaching of Jesus implies no depreciation of wealth in the proper sense of the term. By its very etymology, and still more under scientific definition, wealth can denote only things that are favourable to human weal. Anything that does ill to its owner, whatever may be its value in exchange, ought, as Carlyle puts it, to be characterised as illth rather than as wealth. Now "man's life consisteth not in the abundance of the things that he possesseth." 2 It is not, therefore, by multiplication of possessions that life is really enriched. On the contrary, possessions cease to enrich a man, they make him really poorer, whenever they become a drag on his spiritual progress, which is his true weal.

It is, therefore, a misinterpretation of Christ's whole attitude to social economy when $\mathrm{He}$ is represented as denying or belittling the real value of wealth. It is quite true that, in a familiar figure, $\mathrm{He}$ asserts that it is difficult for a rich man to enter into the kingdom of God. ${ }^{3}$ But the kingdom of God means at least the ideal life; and it requires no special keenness of moral insight to see that wealth, by the power for good or evil which it puts in the hands of its possessor, involves such high

${ }^{1}$ Here again reference may be made to Professor Peabody's Jesus Christ and the Social Question. Chapter vi. deals specially with the Industrial Order, and the two preceding chapters are devoted to the allied subjects of the Rieh and the Care of the Poor.

${ }^{2}$ Luke xii. 15.

${ }^{3}$ Matt. xix. 23, 24 ; Mark x. 25 ; Luke xviii. 25. 
responsibilities that few men can rise to the height of their fulfilment. When this fact has penetrated industrial society more fully, the eager quest of riches, which has formed such a corrupting motive all through the ages, may give way to an awe which shrinks from the tremendous obligations which the possession of wealth entails, and men may prefer that moderate provision for life which the proverbial wisdom of common experience as well as the wisdom of philosophical reflection has recognised as being best adapted to the moral limitations of human nature.

The truth is that the same uncritical method of interpretation which ascribes to Jesus a grudge against the rich, might invent a plausible plea for the contention that He takes an unduly favourable view of the rich as compared with the poor. In the parable of the Talents, ${ }^{1}$ it is the comparatively poor man, the man with only one talent, who appears in an unfavourable light, morally paralysed by a niggardliness that is helpless for good, while it is the comparatively rich men that are commended for rising to the requirements of their duty. The same line of thought runs through the parable of the Labourers in the Vineyard. ${ }^{2}$ Here it is the wealthy landowner, the capitalistic employer of labour, that represents the spirit of generous justice, and it is the labourers who fail in sympathy for his ideal in regard to the remuneration of labour. Moreover, the fact of his owning property is by no means regarded as a moral disadvantage. On the contrary, it is that very fact, the fact of his having a right to do what he will with his own, that gives him the power to carry out the requirements of an ideal justice. ${ }^{3}$

1 Matt. xxv. 15-30.

2 Matt. xx. 1-16.

${ }^{3}$ It would be difficult to find a more monstrous perversion of Seripture than the use of the noble language cmployed by the owner of the vineyard to justify the unscrupulous rich in heartlessly selfish extravagance. 
The desire of genuine weilth, therefore, which is the strictly industrial motive of life, cannot be in itself the source of those evils by which industrial society is corrupter. These evils originate in influences that are altogether extraneous to the motives of peaceful and industrious labour. Among the most prominent of such influences are two which, however different, are yet curiously akin and curiously intermingled in the complicated play of actual life. One is the predatory instinct surviving from an earlier militarism amid the strange environment of industrial civilisation. This instinct finds embodiment still in many a financier, who by his own labour contributes little or nothing to the production or distribution of wealth, but, after the type of an antique brigand, succeeds in enriching himself by plundering the real producers while they are engaged in the complicated process of exchanging their surplus products for mutual benefit.

Akin to the predatory instinct is that which embodies > itself in gambling, for both seek to obtain possession of wealth without undertaking the labour by which alone wealth can be produced. Gambling, therefore, is often associated with the spirit of plunder in corrupting the purity of industrial life. For, driven by law from modes and places of acknowledged gambling, the spirit of the gambler has sought shelter under the forms of legitimate trade, and appears to be so successful in this subterfuge that legislation is often baffled in its endeavour to disentangle the confusion created. An ethical problem is thus presented which lemands a moment's consideration here. It is but fair to point ont that, as in other evil things, so in the evil of gambling, there is a soul of goodness; and it is by frankly recognising this soul of goodness and giving it a fuller play that it will most effectively throw off the evil associations by which it is 
fettered. What then is the soul of goodness in gambling? It is indicated by the very names by which it is known. For the world gambling is merely a frequentative form of gaming. The practice of gambling is thus described as a kind of game or sport. We call it, in fact, sonetimes play, just as the French denote it by jeu, and the Germans by Spiel. Now the impulse which finds vent in play is an irresistible and legitimate instinct in human nature. What is its significance? It means that the strain of the earnest work of life cannot be sustained too long, and must, therefore, be relieved. Such relief is found in activities that are of a totally different class from those described as work. In work there is always some object to be attained beyond the action done. But in actions that come under the designation of sport or play there is no such nlterior object. The joy of the exertion put forth satisfies the player without thought of any further purpose to be gained; and this enjoyment is really adulterated by the admixture of a foreign excitement, such as the effort to make pecuniary gain.

Play, however, often takes a form which allies it more closely with gambling. This form arises from the contrast of play with work. In work, as we have seen, there is always some intelligible purpose, some object in view which can be made more or less certain by rational calculation. Consequently play, by contrast, sften sceks to free itself from the rigid fetters of rational control, to find its fullest gratification in actions that are frankly non-rational; and the very extravagance of the irrationality is often its most rational vindication. Now this playful impulse finds an admirable satisfaction in the so-called "games of chance." The word chance denotes an issue which cannot be rationally calculated beforehand. A game of chance, therefore, is a kind of playful activity in which the sport is drawn from the 
emotional excitement of waiting for an issue which cannot possibly be foreseen. But here again the attitude of mind, which lets things go as they may be irrationally determined by a turn of dice or by a deal at cards, gives a pure fun which is only adulterated by the meaner excitement arising from the chance of peeuniary gain or loss.

With this explanation it will be seen that the ethical problem of gambling must be attacked from two sides. $>$ On the one hand, the serious struggle for gain must not be allowed to corrupt the spirit of pure sport. It neutralises the fun of a game, for it is inconsistent with the essential nature of playful activity, which, as we have seen, seeks no object beyond the simple joy of the activity itself. For, when a man is asked to play for stakes on a game, what does the request imply? Is it not implicitly an insinuation that he is considered to be of too coarse a grain to enjoy the generous fun of sport for its own sake, and that he can be coaxed into play only by the meaner expectation of a possible pecuniary gain?

But, on the other hand, it is still more obviously necessary to eliminate the irrational element of chance from the serious work of industrial life, and to bring that work as thoroughly as possible under the eontrol , of cultured business intelligence. This task is not so hopeless as on first thought it may appear. The main trend of industrial life in our time points to a solution of the problem involved. For the system of competition, which has been commonly described as forming the very , life of trade, is proving itself in experience to be a very different power. With the vast expansions of industrial activity in recent times, unlimited competition is becoming more and more unworkable, and some form of concerted action is now rapidly taking its place. Among producers 
the small master-workman has almost everywhere vanished before the capitalistic employer, the individual capitalist has been unable to hold his own against the joint-stock company, and even joint-stock companies have been obliged to abandon competition with one another and to unite in vaster combinations. In like manner, among distributors, the petty shop, peddling a single class of wares, is gradually giving place to the large departmental store. This process is certainly the most striking feature in the trend of industrial organisation at the present day, and it is displacing that blind scramble for wealth which is inevitable under the un-r restricted competition of individuals. It is true that, by the creation of enormous stocks, this industrial movement has opened or widened a field for gambling operations; but it is growing clearer every day that speculation in stocks is by itself merely a species of gambling, and it is not to be confounded with the genuine industrial work of the producers and distributors of wealth. This work is coming more and more under the control of disciplined intelligence, and even of exact science; and it is thus limiting more and more the field for irrational guessing about incalculable chances. These tendencies of industrial life, it may reasonably be hoped, will train more effectively the habits of just and generous industry, as it is upon these alone that society can depend for the production of those factors of material wealth which are recognised in Christian teaching as indispensable conditions of the highest life.

It is not, therefore, a question with Christ whether men may seek those necessaries of well-being which constitute wealth. He assumes, as every one must, that these have to be procured in some way, and His teaching is designed to explain the method by which alone they can be procured with certainty. In doing so He brings 
us baek to the prineiple, which ought to be the startingpoint of every effort for social well-being, that all aspects of social life must be comprehended in the highest. For if morality means anything in the life of man, it represents the indispensable conditions of well-being in the fullest sense of the term. There cannot, therefore, be any real well-being for man which is inconsistent with morality. That would involve a contradiction in the very meaning of the words. By the same necessity of reason the more completely the moral law is observed, the more completely is man's well-being secured. It is thus on the face of it preposterous to suppose that that aspect of his well-being which is specifically denominated wealth ean be seeured by ignoring the moral law of his life. For wealth, as we have seen, means the condition of human weal. It has, indeed, fallen to a somewhat superficial use. It is commonly limited to the external material eonditions of weal, such as food, clothing, and housing. But it is impossible to separate these from the essential nature of man's weal as a whole, and therefore the external conditions are most unfailingly secured by starting from the innermost source of well-being and working out towards them.

This has been repeatedly pointed out by the great thinkers of the world. "All these goods" (external possessions), says Plato, "are increased by the virtuous friendships of men for one another." 1 More explicitly Aristotle expresses the truth: "Mankind do not acquire or preserve virtue by means of external goods, but external goods by means of virtue." ${ }^{2}$ The same thought receives in Christ's teaching a clearer, fuller, pithier form. For Him, though food and clothing"what ye shall eat, and what ye shall drink, and where-

${ }^{1}$ Plato, Critias, 120.

${ }^{2}$ Aristotle, Politics, vii. 1. 6. 
withal ye shall be clothed"1_are external goods, they are yet necessaries of life; and therefore, as already pointed out, ${ }^{2}$ there is for Hins no ineongruity in the sudden descent from an aspiration after the coming of God's kingdom and the doing of His will to a humble prayer for daily bread. He knows that no man can do the will of God upon earth or work for the coming of His kingdom if he is not sustained with nourishing food. He sees, as Plato and Aristotle did, that the laws of nature are so planned as to connect external wellbeing by irresistible necessity with internal well-being or virtue. But, with that clear vision which went at once to the heart of things, and with that tender beauty of form in which His thought found its natural expression, He puts it, "Your Heavenly Father knoweth that ye have need of all these things." 3 His teaching, therefore, countenances no ascetic grudge against men possessing and enjoying the materials of genuine wealth. He implies rather that the Creator has so planned the world as to enable men to enter into the possession and enjoyment of these. But He warns His disciples against the "Gentile" mistake of trying to secure these by making them the primary object of pursuit in life, and $\mathrm{He}$ points to a more excellent, because it is the only infallible, way: "Seek ye first the kingdom of God and His righteousness, and all these things shall be added unto you." 4 We cannot reach a deeper source of economical well-being than that. Do we realise what an industrial community would be, which had become ar veritable kingdom of God governed by His righteonsness? In snch a community, of course, every man would be perfectly upright in his dealings with others. Instead of seeking to overreach his fellows or to drive a keen

1 Matt. vi. 25 and 31.

${ }^{3}$ Matt. vi. 32.

${ }^{2}$ Above, p. 191.

${ }^{4}$ Matt. vi. 33. 
bargain with them, every one would be eager to do them all the good in his power. Any student of social economy, any man of practical intelligence in industrial life, knows that the wealth of such a community would soon roll up at a rate that the wildest social reformer has never dared to dream. Nor would there be any heartburnings between classes or between individuals about the unfair distribution of the wealth produced; for no man would think that any of the things he possessed was absolutely his own, but distribution would be made to every one according to his need.

What the external form of such a renovated industrial order may be, it is impossible to foretell. The teaching of Jesus Himself, of course, gives not even the faintest outline of such an organisation. It is quite true that in the Acts of the Apostles there is an account of a temporary movement among the primitive Christians of Jerusalem which has a communistic aspect. ${ }^{1}$ But on a careful reading of the narrative the movement is seen to be communistic only in spirit, not in external form. There is no hint of any interference with private property, no hint of communism having been imposed upon the Church as an indispensable condition of membership. What is indicated is such a spirit of brotherly love, of Christian fellowship, that every one considered his private possessions to be at the service of those in need. ${ }^{2}$ One, in fact, Barnabas, is singled out as if he were an exceptional case worthy of special

${ }^{1}$ Acts iv. $32-37$.

2 The ascetic view of property, like that in regard to marriage, spread throughont the Chureh soon after the Apostolic acre. Remunciation of private possessions beeanre, at an early period, an essential virtue among some of the Gnostic sects, and, later, among the mendicant orders. In the modern world it formed the most prominent feature of the Anabaptist movement. But it never beeame part of the catholie eode of the Chureh. See above, p. 87 , n. 3. 
mention, because, being all owner of some land, he sold it and put the price into the hands of the apostles for the relief of the poor. It may be that an industrial society, moulded by the Christian spirit, will tend towards a communistic type, but there is nothing in the teaching, either of Christ or of His apostles, that points to any specific form of industrial organisation as imperative. And this is after all a matter of secondary importance. Any social organisation may by bold bad adventurers be perverted into an instrument for advancing their own selfish purposes; while a society, embodying the purest socialism in its external structure, would still require for its successful administration men imbued with the spirit of Christ.

We are thus brought again to Christ's method-that of moral improvement-as the only effective method of real and permanent social reform. There is indeed a common tacit, if not explicit, assumption with regard to industrial life, like that referred to in the case of political life, that the principles of Christian morality do not admit of application within its sphere. But no scientific system of Ethics can allow any sphere of voluntary action to be beyond the reign of moral law. It is quite true that, amid the vast and intricate complications of modern industry, it is often difficult, at times indeed practically impossible, even with all the aids of economical science, to discern with certainty what line of conduct Christian morality demands. This difficulty is enormously enhanced by the fact of our industrial system being based so largely on antagonistic competi- tion rather than on friendly co-operation. There is, however, in the industrial movements of our day a tendency apparently irresistible, which indicates a disenchantment from the old illusion that competition is the life of trade. It is becoming perfectly clear, even 
to a very moderate intelligenee, that unrestrieted competition must lead to economical ruin, and that, therefore, industrial workers must, in their own interests, come to some sort of concert with one another.

of the forms which this eoneert may ultimately assume, it is, as already stated, futile to attempt a forecast at present. But in working towards an ideal in industrial life, as in other spheres, we must look to the leaders for guidance. It stands to reason that the commanders who direet the vast operations of the industrial army are in a position to discover the exigeneies of the whole situation more fully than the subaltern officers or the private soldier. Unhappily, iudeed, it is impossible to ignore the erimes of appalling selfishness by which, from lack of adequate moral training, many industrial leaders betray the interests of the army which they command, and of the great work with which they have been intrusted. At the same time we must not shut our eyes to the fact that with , many great eaptains of industry there is no lack of will to work along the lines of Christian morality. It is one of the main missions of the Chureh in our day to sustain and direct such industrial leaders, and to add to their number, by the inspiration of her ethical teaching.

The additions must, of course, be sought mainly among the young. But there are multitudes of these to whom the Chureh may hopefully appeal. Many are to take charge of important industries. They are endowed with organising energy and skill. They possess tact in the management of workers. They enjoy an influential rank in society. They are looking forward to the control of large ineomes. They are not incapable of being fires with the Christian ambition of plaeing all these "talents" at the service of their fellows. Frederick the Great is said to have spoken of himself as simply the first servant 
of his country. Why should not the head of a great industrial enterprise regard himself as simply the first servant of the organisation, and, renouncing all pretence of princely or aristocratic ostentation, endeavour to provide for his fellow-workers an opportunity of entering more fully into the boon of our material and spiritual civilisation? No nobler knight-errantry has ever been proposed to men. No more brilliant "adventure" has ever attracted the moral enthusiasm of Christendom. To conquer the giants of selfish greed, to drive out of our Christian lands the paynim who worship a cruel Plutus instead of Christ,- that ought to kindle a new glow of spiritual life in the youth of our Christian Churches. The ideal held before them is none other than that glorious prospect which has buoyed the faith and the hope-the faithful and hopeful love-of all genuine religious enthusiasm, of all speculative reconstruction of society, of all effective social reform. It is that outlook which has taken shape in the truest prophetic visions of an ideal society to be realised in a more auspicious future, moulded by no mere ingenuity of external organisation, but by a moral life which shall draw its inspirations from the Eternal Source of wisdom and love. This is none other than that holy city, a new Jerusalem, which is to come down out of heaven from God, and to form a renovated world with new heavens and a new earth, wherein dwelleth righteousness. ${ }^{1}$

${ }^{1}$ Rev. xxi. 1-2 ; 2 Pet. iii. 13 ; cf. Isa. 1xv. 17, Ixvi. 22. 


\section{PART IV}

\section{THE METHODOLOGY OF CHRISTIAN ETHICS}

\section{CHAPTER I}

THE METHOD OF MORAL CULTURE IN GENERAL

IT is unnecessary to explain that Methodology is the science of Method. It is well also to bear in mind that Method is simply a Greek word for the way of reaching any end. Every science, therefore, may be said to have its method. In fact it is methodical procedure that distinguishes science from common knowledge. Sciences differ in their ends, but in one respect the end of all is the same. It is science itself, or exact knowledge, that is, knowledge characterised by the exactness which method secures, as contrasted with the inexactness of knowledge obtained in unmethodical fashion. Some sciences, however, are distinguished as practical by the fact that knowledge is not their sole or ultimate end. The knowledge acquired in them is used for the ulterior purpose of regulating practice in some sphere of life. It is possible, of course, to cultivate these sciences from a purely speculative or theoretical interest, but their value lies mainly in their practical use. Practical skill, when it can be acquired without scientific theory, is more valuable than mere theory without corresponding skill. 


\section{METHOD OF MORAL CULTURE}

It need scarcely be said that Ethies is a practical science. In it, too, the general principle holds that practice is more important than theory; but the principle holds here with peeuliar force. In this science, practice, when compared with theory, assumes an importance that is infinitely superior. On the other hand, the value of mere theory not only diminishes till it becomes infinitesimal, but-to retain mathematical phraseology-it is converted into a negative quantity. That is to say, theory, divorced from practice, is not only valueless, but it is worse. For when immorality arises from insuperable ignorance, the fault is not so serious as when it is done in disregard of the guiding light of knowledge. ${ }^{1}$ It has, therefore, been the common teaching of all the great moralists, that the end of ethical science is not merely that men should learn to know what virtue is, but that they should become virtuous. Still it is not to be assumed on this account that ethical knowledge is a matter of no importance. On the contrary, a large proportion of the vices of men are due to moral ignorance, and in such cases the first step towards reform must be the enlightenment of moral intelligence. In general, also, the ability to do what is right implies the knowledge of what is right as its prerequisite condition. Accordingly in the Methodology of Ethics there are two ends to be kept in view, and we have to discover the method required for attaining each of these ends.

But in fact the method of both ends is, in its general character at least, the same, because the two ends, however they may differ in some respects, are yet, in one feature, essentially identical. Both in theoretical and in practical science the ain is to develope a certain readiness which we do not possess by nature, which

${ }^{1}$ See Matt. xi. 20-24. 


\section{METHODOLOGY OF CHRISTIAN ETHICS}

must therefore be acquired by some educational process. This process, however, is but one phase of the general process of growth which is characteristic of all life. Every human being, like every other living thing, becomes what he is by virtue of this process. It is this fact which gives importance to the methods of moral culture, and it will therefore receive fuller illustration as we go on. But of course it is not to be understood as implying that there are no powers inherent in the very nature of the mind. On the contrary, training implies, to begin with, some power that is capable of being trained. The difference between the mind of man and that of any animal, many also of the most marked differences between one human mind and another, are differences in nature, not merely in education. The truth is that, while recent psychology has explained many of the so-called faculties of the mind as products of education rather than endowments of nature, it has by no means tended to diminish the mind's natural endowments. It rather tends to set aside the popular view that nature has endowed the lower animals with a peculiar wealth of instincts for their guidance, while leaving man to the guidance of reason. It is more in accordance with the facts of life to say that man is superior to the mere animal, not only in the power of his reason, but also in the number and variety of his instincts. $^{1}$ On this question, however, it is not necessary to enter here. It is sufficient for us that human life is to be explained as the result partly of natural endowments, partly of education.

These two factors are in general briefly distinguished as instinct and habit. Both of these terms denote a certain readiness in action, the one a readiness which we

'Reference may here be made to my article on Habit in Hastings' Encyclopadia of Religion and Ethics. 
bring into the world with us as an original endowment of our nature, the other a readiness which has to be aequired. It is evident that virtue belongs to the latter class. It is true that by nature man is capable of morality. This natural capacity is what is strictly understood by his moral nature. But this moral nature is neither actual virtue nor actual vice. It implies merely the possibility of these, and man becomes actually virtuous or actually vicious only by the habits which he forms. Consequently the end of Ethies as a practical seience is to form virtuous habits, and the method of Ethics must follow the general laws in aceordance with which habits are formed, while indicating such modifications as may be implied in any peculiarity distinguishing moral habits from others.

Now we have seen that all habit is a growth from a germ and a soil furnished by nature. In the eultivation of habits, therefore, the germ and the soil out of which they are cultivated must be taken into consideration. Thus in all moral diseipline we have to reckon with those native dispositions which eonstitute our moral nature. These, unfortunately, are not always towards virtue. There is also, as a common phrase describes it, a vicious nature in men. This, as we have seen, is what appears in dogmatic theology under the name of original sin. We have now to look at this with a practical end in view, that is, for the purpose of finding how it should be dealt with in the training of moral habits.

1. The first fact which claims attention is the individual varieties of moral nature. This is observable both in good and in evil dispositions. It becomes, therefore, an obvious requirement of moral prudence that men should take note of any pecularities in their natural disposition, so that they may regulate their moral discipline with a view to foster what is favourable, and 


\section{METHODOLOGY OF CHRISTIAN ETHICS}

to repress what is unfavourable, to virtue. This demand is precisely analogous to what is recognised as one of the simplest lessons of prudence in matters of bodily health. If a man knows that from heredity or any other cause he is liable to any peculiar form of disease, he is always deemed guilty of inexcusable imprudence if he does not regulate his life so as to guard against the danger to which he is exposed. It is on the same principle that prudence calls for precaution in dealing with the peculiar dangers of moral life. Such dangers may lie, not only in dispositions that are positively hurtful by their abnormal force, but also in the lack of counteractive dispositions. Thus vices of the malicious type may be stimulated, in the first instance, by an unusual irritabilty of natural temper, but they may also be aggravated by the sympathetic nature being too feeble to offer any effective resistance. When any man becomes capable of reflection, and capable, therefore, of regulating his life intelligently, it is not difficult for him to discover the leading facts of this kind in his natural endowment; and in the interest of all that is worth achieving in life it becomes imperative to discipline himself habitually by a prudent regard to his moral requirements.

2. And he is encouraged to do so all the more hopefully by the fact that natural dispositions are not the irresistible forces they are often supposed to be. The exact ratio between natural faculty and acquired faculty it is not necessary, even if it were possible, to define. But we have already seen that, in the proverbial experience of men, habit has come to be regarded as capable at least of evolving a second nature. When this common experience is enlarged and corrected by scientific observation, the facts present some interesting features. Instincts themselves are found to require an 
appropriate environment in order to be stimulated into action; and if such an environment is not provided, they never manifest themselves at all, literally dead-born for want of the stimulus necessary to life. Moreover, even if they are called into life at first, they cannot become permanent agencies except by being kept in continuous activity through the stimulus of a proper environment; and from lack of this they may become enfeebled or even vanish altogether. This is peculiarly the case if an instinct is not only left to die for want of stimulus, but is counteracted and at last supplanted by an incompatible habit. Numerous illustrations of this from animal life are given in the literature of Biology. ${ }^{1}$ A familiar illustration is furnished by those groups of animals which, under such names as that of "a happy family," are sometimes exhibited as popular shows. In these collections, animals that are natural enenies are found living in perfectly amicable association, the predatory instinct on the one side and the instinctive fear on the other having been completely supplanted by counteractive habits. Innumerable experiments are constantly proving how in wild animals the instinctive fear of man can be eradicated, and in many cases eradicated very soon, by habituating them to kindly human society. Our barnyards often furnish instances of the common domestic hen modifying her instincts to suit those of a brood of ducklings, so that afterwards, when she is set to rear a brood from her own eggs, she will endeavour to force her chicks to take the water.

These facts in the life of the lower animals find their counterpart in the life of man. With him, too, the original instincts of nature are often supplanted by acquired habits. One of the most painful, and unhappily

1 The chapters on Instinct in Romanes' Mental Evolution in Animals still remain a classical treatment of this subject. 
one of the most eommon, tragedies in human life is that presented by the babit of aleoholie indulgence overcoming all the higher instincts which contribute to human welfare. Other vices, like gambling, produce a similar effect. One of the most striking examples of the effect is that furnished by the miser. This remarkable product of habit has formed a favourite theme for comical portraiture of character, perhaps because of its intrinsic ineongruity with the common instinets of human nature. For money, being of value merely as a symbol of the value of other things, might well be supposed ineapable of calling forth any desire or effort exeept for the sake of the things which it is the means of purehasing. Yet when the desire and the effort to gain money have acquired the foree of a habit, the habit suppresses the instincts out of which it grew, the love of money displaces the love of those natural gratifications for which alone money is desirable.

This power of habit to overcome the primitive instincts of human nature is strikingly expressed in the fact that extreme examples of moral degradation are described as inhuman or as monsters. Such monstrous developments, when they run in the line of sensual, animal indulgence, are stigmatised as brutal or bestial; when they take the type of inhuman malice, as diabolic. It is pleasant, moreover, to bear in mind that there are extraordinary developments of moral character in the opposite direction, which excite admiration as being so far above the level of common humanity that they appear to be heroic or angelic, to be even divine or godlike. ${ }^{1}$

${ }^{1}$ Students of Aristotle will rememher that he recognises, on one side,

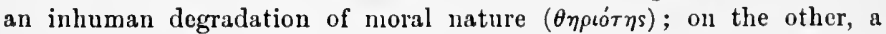
superhuman elevation ( $\dot{\eta} \dot{i} \pi \dot{\epsilon} \rho \dot{\eta} \mu a \hat{s} \dot{\alpha} \rho \epsilon \tau \dot{\eta}$, $\dot{\eta} \rho \omega \ddot{\kappa} \kappa \dot{\eta} \tau \iota s \kappa a i \theta \epsilon i a)$. See Eth. Nic. vii. 1. 1-3, 5. 6, 7. For him, indeed, these characteristies are rather attributes of a distinctive nature than attainments of moral effort. Brutality is therefore distinguished from vice, while heroism is conceived 
It thus appears that the value of instinct, in the first instance, is to be found in the stimulus which it gives to babitual activity; and it is only when it is converted into a habit that it becomes a regulative foree in life. It appears also that the foree of instinct can be completely neutralised by the force of counteracting habits. It is these facts that give to habit the potent influence which it exercises over the life of man. Certainly, so far as his moral life is concerned, he is truly described as a creature of habit.

3. This brings us to the method of moral culture. That method is evidently to be found in the training by which habits are formed. Whether the original tendeneies of our nature are to be strengthened or weakened, the end in view can be attained only by the formation of an appropriate habit. We are thus led to inquire into the nature of the process by which habits are formed. Fortunately this process is such an obtrusive phenomenon in human life, that its general nature at least is well known to common observation without any strictly scientific study. All are familiar with the general law that a habit is acquired by practice; in other words, by frequently performing an action we aequire at last a certain readiness in its performance which we did not possess at first. When this law is examined, it is found to eome under a law more general. This more general law is also familiar in human experience, and is known, both in the language of science and in the language of common life, by the name of association or suggestion. It is well known that facts which have been associated in the mind tend to suggest one another

as something higher than virtne. But though in many cases, if not in most or even in all, such abnormal developments may take their primal origin from differences of nature, their actual power in life depends on their subsequent habitual indulgence. 


\section{METHODOLOGY OF CHRISTIAN ETHICS}

afterwards, and that a great part of education consists in forming such associations with a view to the associated facts being readily recalled by suggestion. This is evidently the process implied in the formation of habits; and consequently the problem for us is to discover the laws in accordance with which associations are strengthened so as to increase their suggestive power. Now, there are two main influences at work to this effect: these are the intensity with which an impression is made on the mind, and the frequency with which it is repeated. There is a third influence commonly recognised as adding to the suggestibility of an impression, namely its recentuess; but this may be left out of account at present, as it is constantly being called into play afresh by repetition.

(1) First of all, then, our success in the formation of any habit depends upon the intensity of the impressions made upon our minds; in other words, it will be greatly facilitated by the earnest, enthusiastic determination with which we apply ourselves to the task. This intensity of application is important all through the continued discipline by which habits are acquired; but it is specially valuable at the start. The beginning of many a habit dates from some unusually intense impression that may come involuntarily. Such is the overpowering stimulus that originates from the spiritual crisis of conversion. It is a simple matter of fact that this stimulus often completely and suddenly revolutionises the most important habits of life. Apart altogether from its religious significance, therefore, the value of conversion to the moral life cannot be ignored. It creates an impulse to the formation of virtuous habits which can scarcely be found in any other discipline. Even after conversion the benefit of an intense impression may be renewed at intervals, as the discipline 
of spiritual life is turned to fresh achievements. This is commonly done by taking some decisive step which commits us to a certain line of conduct, so that for very shame we dare not turn back upon our decision. In varying figure we are said to cross some Rubicon in life, to burn our ships, or to nail our colours to the mast, so as to let it be known that we are ready, if need be, to die in the struggle on which we have entered, but that we shall never surrender. The general principle of this spiritual discipline is recognised by our Lord in those incidents of which the significance is summed up in the saying that "no man, having put his hand to the plough and looking back, is fit for the kingdom of God." 1

(2) But the very intensity of the impulse received at conversion is accompanied with a danger to which attention was drawn above. ${ }^{2}$ And now, with a view to the training of virtuous habits, it is once more important to be reminded that an initial impulse is not of itself sufficient to sustain the prolonged process of spiritual culture. In fact the value of initial impulse in the evolution of moral life may be compared to that of instinct in the evolution of life in general. It stimulates and thereby facilitates those activities by which life is evolved. But, as we have seen, instincts themselves may die from lack of exercise. So the intensest impulses may soon expend their force if they are not constantly renewed. Every one, therefore, is surprised to find how rapidly and how completely even intense impressions are forgotten if they are never repeated. It is this fact that renders so futile for mental training the process of cramming knowledge for use at an examination or for any similar temporary purpose. Although by intensity of applieation the knowledge may be mastered so thoroughly as to be recalled readily

$$
{ }^{1} \text { Luke ix. 57-62. }
$$

2 Sce p. 175. 
for use on the occasion for which it is required, often a few days are sufficient to wipe the whole from memory so completely that even our written memoranda may appear foreign, and be recognised as our own merely by the handwriting. It is only by continuous practice that any of our acquired faculties are kept at their best. Without that the most expert find that they very soon become "rusty," and for any special trial of skill some previous disciplinary exercise is an indispensable training.

All this applies to moral habits with the same force as to others. They too can be trained in the first instance, and kept at their best afterwards, only by constant exercise. But the exercise by which habits are acquired and preserved is a discipline specially designed for the purpose. The practice of such a discipline is what is always understood by learning, training, education, and terms of similar purport. This fact is sufficiently recognised in other branches of education; yet it is strangely ignored so far as the requirements of moral life are concerned. If our educational systems are considered with a view to this, they can hardly fail to strike the mind with surprise by the poverty of their adaptations for moral discipline. There is indeed a feature of school-life which is spoken of as discipline; and it is regarded as absolutely essential to the working of any educational institution. It must also be acknowledged that the discipline of a school is a potent factor of its moral influence. It tends to emancipate the pupil from the dominion of variable caprices and passions; it makes him regulate his conduct by law, by the established order of the school. But this discipline is not strictly a part of the educational work itself; it is the condition necessary for carrying on that work. A discipline designed specially 
for the training of moral habits is conspicuous rather by its absence. It, certainly forms nó prominent feature in the plans or in the work of our educational institutions.

This defect is all the more glaring when it is contrasted with the elaborate equipments and arrangements provided for other kinds of education. Thus, for example, there are often spacious and stately buildings equipped with all the instrumentalities of gymnastic exercise to furnish the means of physical culture. But it is intellectual culture that has generally formed the dominant aim of educational work; and whatever may be said about the various schemes which are advocated for this end, they all contemplate a vast amount of steady regulated effort on the part of pupils to cultivate intellectual habits. It can hardly be pretended that our educational arrangements generally provide any similar disciplinary labour to train the moral habits. These are left in a large measure to grow up spontaneously under such stimulation as they may receive from social intercourse. Is it any wonder that the results in moral life are so disappointing? The results would be similar in intellectual life if the same method were adopted, or rather if the same lack of method prevailed in the culture of its habits. Suppose, for example, children were left to acquire skill in numerical calculation by such practice as is forced on them by the unavoidable exigencies of life, the vast majority would never get beyond the most rudimentary power of counting by their fingers. The same stunted development would meet us under the same conditions in every other direction of intellectual activity. Yet this stunted development does not seem to excite surprise or any determined remedial effort in the sphere of moral life. 


\section{METHODOLOGY OF CHRISTIAN ETHICS}

What is the remedy for this state of things? Evidently the adoption of a discipline similar to that which is used for intellectual and physical culture. But this means that children must not be left to practise virtue merely when they arc called to do so by the imperative demands of duty. That is not lcarning to be virtuous; it does not imply moral education or training in the proper sense of these terms. The pupil in morality must be set to specific tasks which are designed to train moral habits and are performed for that definite purpose. What is the nature of these tasks? The answer to that question will form the subject of our concluding chapter. 


\section{CHAPTER II}

SPECIAL METHODS OF MORAL CULTURE : THEIR DANGERS AND SAFEGUARDS

THE specific tasks or exercises referred to at the close of last chapter must be adapted mainly to develope the power of will, that is, the power of habitually responding to the call of duty. The habit of virtue is readiness in making that response. This habitual power of will, as moralists have seen from of old, implies two forms of control. It implies a power of controlling both the attraction towards pleasure and the revulsion from pain. Consequently moral discipline must be made up of exercises in which the pupil forces himself to give up pleasures and to endure pains, even when he might enjoy the pleasures and avoid the pains without any dereliction of duty. It is not enough to bear pains which are entailed in the performance of duty, to surrender pleasures which duty forbids. Pupils in the school of morality might thus do all that the moral law strictly enjoins aud would yet be obliged to confess, "We are but good-for-nothing slaves; we have done only what we were bound to do." 1 The truth is that the discipline required for moral culture seems to give an intelligible meaning to a doctrine which has been unfortunately darkened by dogmatic complications. These complications may here be left out of account,

${ }^{1}$ Luke xvii, 10. 


\section{METHODOLOGY OF CHRISTIAN ETHICS}

and the doctrine viewed in its purely ethical aspect. The tasks which moral discipline enjoins may not inappropriately be described as works of supererogation. It is true that some such tasks are imperatively required of every human being. But a large sphere is left for freedom of choice in regard to the particular tasks to be adopted and all the regulations by which they are enforced. In most cases probably other exercises might have been adopted with equal profit, or they might equally well have been practised at other times or under other conditions. They thus appear to lie beyond those rigid requirements of the moral law which are of imperative obligation at the moment when they arise. They are in this sense supererogatory or superobligatory. They may even, like the actions technically described as works of supererogation, be spoken of as counsels of perfection; for they aim at a perfection of character beyond any that is otherwise attainable.

Although our educational systems do not give prominence to moral discipline, its necessity has always been recognised by moral and religious teachers. In fact, religious societies have often devised a more or less elaborate code of exercises for the discipline of moral life. Such are the fasts and penances of the Christian Church, which find their counterpart in other religions. In its essential meaning fasting is evidently abstinence from a gratification which is in itself allowable, but of which we deny ourselves the enjoyment simply for the purpose of training the will in power of self-denial. In like manner penance is essentially the optional endurance of a pain or hardship which is not called for by the immediate duty of the moment, but which is undertaken for the specific purpose of schooling the will to endure pain or hardship in the performance of duty. An elaborate code of such disciplinary exercises may, of 


\section{SPECIAL METHODS OF MORAL CULTURE 305}

course, be drawn up and enacted by social authority, but it is extremely questionable whether it can be enforced with profit in any large society. In fact the enforcement of moral disciplines by an external authority is apt to interfere with the very end of these disciplines, and that in two ways.

1. In the first place, to make any moral discipline effective, it is essential that it should be a perfectly voluntary undertaking on the part of the individual, as its specific purpose is to train his will. But when a code of disciplinary exercises is prescribed by some authority extrinsic to his will, it assumes the appearance of a law designed to regulate, not his will, but his external conduct. $\mathrm{He}$ is then apt to be satisfied with his fulfilment of the law if he practises the prescribed exercises as purely external actions without regard to their effect in the training of his will. The whole history of canonical fasting and penance is a revelation of this tendency, but its disastrous effects have been specially conspicuous in connection with those relaxations of the authorised code which have won an opprobrious reputation under the name of Indulgences. The danger in question is likely to be most serious in the case of those who are young in years or young in moral development, and who can therefore seldom distinguish clearly between the letter and the spirit of a regulation in any sphere of life. Yet these are the very persons who stand most urgently in need of a discipline that is really moral. It would seem, therefore, as if a disciplinary code could be of moral value only as a body of suggestions in regard to the exercises that each individual might select for his own moral wants.

2. This is confirmed by a second requirement of moral discipline. To be effective, such a discipline must not only be voluntary, it must also be secret. That 


\section{METHODOLOGY OF CHRISTIAN ETHICS}

is to say, it must throw aside all appearance of external display, it must be undertaken solely for its unseen effect on the moral character. But a code enacted by a social authority must, of course, be published for the use of the society that is to be guided by its regulations, and the enforcement of these regulations must attain more or less publicity too. This unfortunate feature of disciplinary codes has also manifested itself in the corruptions of moral and religious life. It will be remembered that in our Lord's time the ostentatious display of their rigid disciplines by many of the Pharisees called forth some of His severest denunciations. But $\mathrm{He}$ indicated at the same time the real source of the profit that may be derived from such discipline. It must be directed specifically to its purpose of moral culture, and it can be so only when every interest calculated to divert it from that purpose is rigidly excluded. But if that is done, then with certainty the effect to which the discipline is adapted will follow, the moral disciplinarian will assuredly have his reward.

As indicated above, all this is merely another way of saying that in all moral discipline the end which it is designed to serve should be kept constantly in view. This seems a truism so simple and obvious as scarcely to require explicit statement; but it is just the oversight of such simple truisms that entails the most glaring imperfections of moral life. All through the life of man, indeed, as we have seen from some examples already, there is a tendency to lose sight of remoter ends by being absorbed in the immediate ends which are the means of attaining the others. It is true that this is for the moment often indispensable to success, indispensable to the attainment of the remoter ends themselves. But it is attended with an obvious danger. 
For the immediate end, though merely a means to something beyond, is not only elevated into prominence for the moment, but is apt to assume such continued prominence as to exclude permanently from view the remoter purpose which it is intended to serve, and which alone gives it value.

The evil of this result may be traced through all forms of discipline by which the life of man is trained to its highest excellence. Even the discipline designed to develope bodily vigour does not escape the evil. Gymnastic exercises are often elevated into an independent value without reference to the health and strength which it is their function to secure; and consequently they defeat, instead of attaining, their purpose. This is especially the case when to the pure interest in gymnastic exercises are added all the varied interests associated with athletic competitions. Aristotle had long ago sounded a warning against this danger. With the thoroughly Greek sentiment embodied briefly in the proverb $M \eta \delta \dot{e} \nu$ ă $\gamma a \nu$, and more elaborately in his own theory of virtue, he draws attention to the inevitable risk of excessive and exhausting strain which athletic contests entail. He dwells especially on the injurious effect upon the young; and as a proof of this he mentions the seriously significant fact that only in two or three instances had a victor at the Olympic games won a prize both in boyhood and in manhood. ${ }^{1}$ No one who makes a reflective observation of competitors at athletic sports in our own day, can fail to be impressed with a painful suspicion of the justice of Aristotle's warning. It would seem, therefore, as if even in this sphere of discipline it were necessary to go back upon the elementary principle of wisdom, that the end must not be sacrificed to the means. For the moralist the 


\section{METHODOLOGY OF CHRISTIAN ETHICS}

end of all physical training is to develope that healthy vigour of body which is an indispensable condition of the best life for man. That end is to be attained most fully and certainly not by athletic competitions in which the competitors are called to strain their powers to the uttermost, but rather by moderate gymnastic exercises planned and regulated by medical science.

The warning in regard to physical discipline finds its counterpart as we pass to the psychical side of moral life. The virtue of temperance in its widest meaning comprehends, as we have seen, all those forms of selfcontrol which imply a check upon the natural cravings that arise from the attractiveness of pleasure. Accordingly, as we have also seen, it requires for its development a discipline consisting in special exercises of selfdenial-that is, exercises in which we deny ourselves a pleasant indulgence, not because the indulgence would in itself be wrong, but simply to train the power of voluntary self-control. But such exercises create and foster a certain attitude of the mind towards pleasure in general. During the moment of the exercise the surrender of a pleasure, which in itself is innocent, becomes a virtuous act-virtuous because of the virtue which it is calculated to train. But here again the end is apt to be overlooked in the immediate requirement of the means. The sacrifice of any pleasure, whatever its nature may be, comes to be thought of as virtuous in itself without reference to the end which it is designed to serve. By the same process of thought, pleasure in general is at last viewed as an evil, and total abstinence from it is made the prominent feature of a virtuous character. This is the phase of morality commonly understood by the name of asceticism. It is, in fact, an exaggerated estimate of the value of disciplinary exercise (á $\sigma \kappa \eta \sigma \iota s)$, substituting that exereise for the virtue which 
it is the means of training. Asceticism has formed representative sects in all the great religions of the world, and has unfortunately in many minds thrown around the religious life an unattractive, if not even a repulsive, gloom. Among the English-speaking communities it has been commonly associated with the great historical movement of Puritanism, though not so uniformly as has often been represented. As a purely ethical system it formed a dominant characteristic of the ancient Cynics.

The same ascetic aspiration which aimed at overcoming the attractiveness of pleasure, endeavoured to attain its end also by overcoming the repulsiveness of pain. Moral discipline then assumed the form of inflicting voluntary severities over and above such sufferings as are inevitable in the natural course of life. But here again the end has been frequently ignored in the prominence given to the means. The voluntary endurance of suffering has come to be viewed as an end of value in itself without regard to its effect on the moral character. In fact the moral character has often in this way been degraded to a distinctly lower type. For the only way in which the ascetic ideal can be reached is by hardening the natural sensibility. But this process necessarily eliminates the finer sentiments as well as the coarser passions of human nature, and the extreme ascetic becomes a degenerate monster who has reconciled himself to a type of life revolting to normal humanity. In general, even physical as well as moral health is sacrificed by this substitution of a mere discipline for the end to which it ought to be subordinated. Many a life has been made a physical wreck by excessive penances and fastings. This has been the case not only in ascetic religious communities, the great political community of the ancient Spartans 
took its national character from the stern discipline by which its citizens were trained. But there, too, the aim was apt to be defeated by an exaggerated estimate of the discipline employed. Evon as late as the time of Plutarch, Spartan boys sometimes died under the lash by which they were disciplined before the altar of Artemis-a veritable human sacrifice to a savage perversion of the ideal personified in that goddess. ${ }^{1}$

It is only fair to asceticism, however, to point to the danger that lies in any excessive reaction against its hardening effect on the sensibility. It is true that the finer sentiments play an essential part in the moral life, and that they, like other mental activities, can be cultivated only by exercise. It is true also that the mere exercise of refined sentiment may claim to be a legitimate end in itself, which does not require the justification of any ulterior purpose. But that very fact constitutes a peril to practical morality. For the indulgence of our emotional nature, however legitimate, is restricted by the inexorable law of moderation; and whenever the limit of moderation is exceeded, the sensibility assumes an injurious predominance. Although the gratification of a cultured sensibility may be an end itself, yet its most important function is to stimulate moral activity; and the frequent indulgence of sentiment without any corresponding action tends to create an habitual dissociation of the two. This habitual dissociation gives rise to that form of moral feebleness in which energy terminates in sentimental excitement, never going out in the performance of any good work.

To guard against such perversions of moral discipline as have been described, the most essential requisite is the cultivation of moral intelligence, and therefore, one of the most important parts of the discipline of life is that

1 Plutarch, Lycurgus, xvi. 
which points to this end. But the cultivation of moral intelligence does not differ essentially from that of intelligence in general; and, as we have already seen, the methods of intellectual culture generally form the most prominent feature in our systems of education. The culture of moral intelligence must consist in the application of those methods to the particular phenomena of moral life. What is the essential feature of those methods? It is that which is found in all methods of discipline. It consists in the prescription of special exercises. Such exercises can, of course, be invented in the region of moral activity as elsewhere. They take the form of questions or problems with regard to the morality of particular actions or particular rules of conduct. These become what are spoken of as cases of conscience (casus conscientice), and that part of moral science which deals with such problems has therefore been designated casuistry. ${ }^{1}$ This discipline has unfortunately fallen into disrepute, so that it is scarcely ever mentioned without a certain amount of opprobrium. Yet in its essential nature casuistry is simply the method adopted in all spheres of intellectual work for training the mind to solve the problems with which it is called to grapple, and it is difficult at first to see why this method should be tainted with any peculiar flaw in its application to the problems of morality. The source of this taint, however, is not beyond discovery. It may be traced, in a large measure, to that tendency by which other disciplines are perverted when they are made independent ends, not merely means to something higher.

There is, indeed, for the practical work of life a

1 The vast literature of casuistry does not call for notice here, but reference may be made to one of the most recent discussions of the subject in Dr. Rashdall's Theory of Good and Evil (1907). The concluding chapter of this work is devoted to the Possibility and Limitations of Casuistry. 


\section{I 2 METHODOLOGY OF CHRISTIAN ETHICS}

general danger in an education that is too exclusively intellectual. Effective work in any sphere demands prompt and complete concentration of energy on immediate ends. But the culture of intelligence exclusively tends to develope a habit of mind incompatible with such concentration. The keenly inquisitive intellect keeps searching for all the possible alternatives which a situation offers; and, perplexed by their contending claims, often allows the irrevocable moment for decisive action to pass while still occupied in irresolute speculation.

"And thus the native hue of resolution

Is sicklied o'er with the pale cast of thought;

And enterprises of great pith and moment, With this regard, their currents turn awry, And lose the name of action." 1

At times this abnormal preponderance of intellectual activity over other activities of the mind takes a peculiarly morbid direction in moral life. The intellect, prying into all the facts with an eager curiosity, is apt to dwell with a self-torturing anxiety upon insignificant details, and to create the character of the stickler for trifles, who is often one of the most intractable impediments to effective work in the social life of the world. Is not this the character against whom a warning is sounded in the familiar injunction, "Be not righteous overmuch, neither make thyself over-wise; why shouldst thou destroy thyself" ? ${ }^{2}$ At all events, in face of the imperative calls of daily and hourly work, this habit of mind cannot but prove extremely disastrous; and when it is found that, in the interest of casuistical inquiry, the urgent duty of the moment is ignored, it naturally appears as if the discipline of casuistry, instead of enlightening, tended rather to darken the moral intelligence of men. No wonder, tlierefore, that the man

${ }^{1}$ Hamlet, Act III. Scene 1.

2 Eccles. vii. 16. 
in whose mind the practical work of life predominates over all speculative curiosity should unceremoniously sweep aside all the intellectual cobwebbery of the casuist, preferring to do whatever his hand finds ready to be done, and to do it with all his might, in the faith that that is the clearest call of moral intelligence. The same phenomenon is seen in other spheres of life. The scientific engineer has sometimes obstructed the progress of his art by theoretical difficulties which have given way before the resourceful energy of the practical mechanic. Many a Gordian knot of speculation has puzzled the intelligence of man, till some young Alexander appears, and, by cleaving it in two, resolves its entanglements as effectively as if it had been untied by years of toilsome examination.

The perversion of casuistical discipline is apt to be aggravated by another cause. For the vigorous mind there is a joy in the intellectual exercise by which it is trained. Accordingly men often take up a problem of school-life as a pleasant recreation of maturer years; just as, if they retain vigour of body, they occasionally for pure sport take a turn at one of the old games of the playground. It is thus that problems which give scope for agreeable intellectual exercise will always have a certain fascination for the mind. The indulgence of this amusement is, of course, perfectly innocent in itself, but it is fraught with an obvious danger. The amusement is apt to develope the dialectical habit of mind, which finds a certain exhilaration in the thorough discussion of a problem, and in the alternate championship of different solutions. It is unnecessary here to trace the varied influence of this dialectical habit as it is revealed throughout the history of the human mind. Few phases of mental life are more familiar than the spirit which delights in disputation for the mere sake 


\section{I 4 METHODOLOGY OF CHRISTIAN ETHICS}

of disputation, without any great concern about the truth on the matter in dispute. Among the innumerable subjects of thought there is ample scope for innocent indulgence in this amusement. But even on questions beyond the realm of morals, the habit of mind which seeks this gratification has often corrupted the earnest inquiries of scientific thought. These have degenerated under its influence into shallow quibbles scarcely rising above the level of a mere play upon words or a trick of logical forms. This unhappy result, however, becomes peculiarly disastrous in the region of ethical thought. Some of the lighter ethical problems, indeed, may be made the themes of transient dialectical sport as long as it is understood to be mere sport, and is not palmed off upon any one as earnest intellectual work. But in general ethical problems are out of harmony with the spirit of fun. They are too closely wrapped up in the serious work of life. They require, therefore, for their successful solution a spirit of earnestness in unison with their own earnest significance. The man who approaches them for the playful purpose of indulging dialectical ingenuity has taken up an attitude which unfits him more or less completely for the inquiry on which he enters. His ingenuity may at any time bewilder the court of his own conscience, and snatch from it a verdict which sets its highest rules of procedure aside. It is not surprising, therefore, that the casuist has come to be thought of commonly, not as one who uses his highest intelligence to discover the path that leads most clearly away from every appearance of evil, but rather as one who prostitutes his intelligence for the purpose of obliterating or blurring the sharp line of demarcation that rigidly separates the evil from the good.

All this, however, forms no sufficient objection to casuistry in itself. It claims a place with other 
disciplines for training the mind; and, like other disciplines, it loses its value, it becomes even injurious, when it is made an end in itself, to the neglect of the higher purpose which it is intended to serve. As a matter of fact, all men are casuists. Among the common topics with which their minds are occupied, morality takes a prominent, if not even a predominant, place. In the gencral conversations of social circles no questions come up more frequently than those which refer to the rightness or wrongness of particular actions or particular rules of conduct. Even the complicated problem of a person's moral character is one which the ordinary mind rarely shrinks from grappling. For many interests, therefore, besides those of disciplining moral intelligence, it is of supreme importance to direct the mind properly in the treatment of casuistical problems. Now there is one principle which alone can direct to the solution of the problems with which it is called to grapple, and that is to view the facts under consideration in their connection with the general system of things to which they belong. In its highest reach this principle implies an endeavour to view all things as they must appear to a Perfect Intelligence, an Intelligence by whom they are perfectly known.

This principle, indeed, has an obvious application to the discipline of intellectual life in general. Implicitly all genuine intellectual work is an endeavour to reach the point of view of an Intelligence that is absolutely perfect, and to understand the subject of study as it must be understood by such an Intelligence. Whether explicitly conscious of it or not, the earnest intellectual worker is in all his labour endeavouring to enter into communion with God. It would therefore be a valuable discipline for intellectual life in general if the intellectual worker were trained to keep before his mind the 


\section{METHODOLOGY OF CHRISTIAN ETHICS}

perpetual presence of the Perfect Intelligence who is the ideal of all his labours. Accordingly, it is not without a rational vindication that religious exercise has been generally associated with educational work in the history of Christendom at least, and it is worthy of earnest consideration whether the value of this exercise as an intellectual discipline might not be more emphatically recognised. This holds especially of universities and other schools of higher education, where it is of prime importance to develope into a dominant influence over life the intellectual virtue of the love of truth. For the daily educational work of such institutions, could there be a preparatory discipline more effective than a simple morning service adapted to raise the finite reason of the worshipper into communion with the Infinite Reason of the universe, drawing an additional inspiration from some composition of the great masters in sacred music, and from the suggestions of a chapel constructed and decorated by a pure religious art?

But this general discipline is of peculiar value for the clirection and inspiration of moral life. This fact comes out with singular force in the practical attitude of many thinkers who maintain a speculative attitude of doubt, if not of negation, in regard to this central idea of religious thought. While holding that the Perfect Intelligence must, from a speculative point of view, remain a mere ideal, they yet recognise it to be for the practical interests of life so valuable, if not so indispensable, that they claim the right, or even assert the duty, of using it as an ideal for guidance and inspiration. The categorical imperative, in which Kant embodies the supreme principle of practical reason, is but an abstract expression of this ideal ; and consequently the ideal becomes for him a postulate of practical reason, forming the sole, but irrefragable, ground of belief in the 
existence of the Supreme Mind. Whatever force may be allowed to Kant's reasoning, it too gives an impressive proof of the necessity of the religious ideal for the moral life. We have thus the true aim of all the religious discipline by which the elevation and fervour of the Christian life are sustained. Such a discipline must, in its original plan and in its actual use, be designed to awaken when dormant, and to stimulate when flagging, the consciousness of our being always in the presence of the Infinite Mind. Different exercises may be invented for this purpose, and each individual will find it to his advantage to adopt such as are proved by personal experience to be most effective for himself. But it is an admirable discipline for all to train the mind to the habitual use of some consecrated language in which the ideal of all intelligence-the unavoidable presence of the Infinite Mind-has found noble expression. In nobility of phrase and consequent fitness for inspiring use no expression of this thought surpasses the familiar words of the old psalm: "Whither shall I go from Thy spirit? or whither shall I flee from Thy presence? If I ascend up into heaven, Thou art there: if I make my bed in the under-world, behold, Thou art there. If I take the wings of the morning, and alight in the uttermost parts of the sea; even there shall Thy hand lead me, and Thy right hand shall hold me. If I say, Surely the darkness shall cover me, and the light about me shall be night; even the darkness hideth not from Thee, but the night shineth as the day: the darkness and the light are both alike to Thee." 1

But besides any general discipline of this kind, there are for the same purpose all those special disciplines which are commonly spoken of as religious exercises. In many works these are put into a separate class of

${ }^{1}$ Ps. cxxxix. 7-12. 


\section{METHODOLOGY OF CHRISTIAN ETHICS}

obligations, distinguished as Duties to God, co-ordinated with Personal Duties and Social Duties or Duties to Others. This classification may have a certain convenieuce for popular exposition and practical enforcement, but it cannot be vindicated as in harmony with the requirements of logical division. In the first place, the three classes are not logically co-ordinate. Duties to God cannot be reduced to the level of duties to ourselves and to our fellows. In any sense in which we can speak properly of a duty to God, it must be regarded as the universal obligation of moral life, comprehending the duties to ourselves and others, in which it is realised. ${ }^{1}$ Then, in the second place, the so-called duties to God are not really duties which we owe to Him in the sense in which we owe duties to ourselves or to other men. They are properly disciplines which we ought to practise for the training of spiritual character. They are, therefore, significantly spoken of as means of grace. The phrase is significant, because it points to their true place in the Christian life. They are means; and, as we have seen, they are perverted from their proper use when they are elevated to the rank of independent ends so as to conceal the end to which they ought to be subservient. This end, as has been sufficiently explained, is to maintain that uninterrupted communion with the Infinite Mind which will habituate our minds to look at the duties of life, as far as possible, from His point of view.

Here it is well to be reminded what this habituation of the mind implics. It does not imply that the mind is always consciously occupicd with those ideas that are distinctively called religious. We have already seen that, to attain the remoter ends of life, it is generally necessary that our energies should be concentrated on

\footnotetext{
${ }^{1}$ See above, pp. 37 and 225.
} 
the immediate ends which are the means of their attainment. Thus it is that, in our endeavour to fulfil the supreme duty of loving God with the whole heart, we must be absorbed in the little duties of the hour which that supreme duty involves, the duties in which we carry out the will of God with regard to our neighbour and ourselves. The very completeness with which we have trained ourselves habitually to the love of God, may thus appear in the completeness with which we seem to forget it in our devotion to the duty of the moment, which the love of God demands. But if in this way the love of God ceases to be a lifeless abstraction of thought or an idle sentiment, and becomes a living reality, the daily tasks of life lose all appearance of petty, meaningless, transitory incidents; they become glorified with an infinite significance as working out the will of the Eternal. It is well to bear in mind, further, that this infinite and eternal significance is not to be measured by the extent of the stage on which the work of life is done, or by the splendour with which it may dazzle the vision of men. The work of our Lord Himself is never referred to by the early historians of the Roman Empire, except in an occasional phrase of contempt; and yet it was by far the most potent influence in the very history they undertook to record. So in His eyes a widow's mite could be of more value for the treasury of God than the munificent contributions of the wealthy, while any little deed of kindness done to the very least of His brethren had the same significance as if done to Himself.

The great inajority of human beings are ealled to pass their lives in what appears as a monotonous round of insipid tasks that seem to be without value for the vast interests of the world. But the dullest 


\section{METHODOLOGY OF CHRISTIAN ETHICS}

routine in the obseurest sphere of life may be made radiant with heavenly light, and those who are called to such routine may find a diviner satisfaction in their apparently unenviable lot than is granted to many whose brilliant display draws upon them the envy of the world. Some, too, who are bewildered by the clamour of contending creeds, and are inclined to despair of ever discovering the true Chureh of God, may eatch a glimpse of the method by which their doubts are most likely to vanish. There is an old legend of a cathedral which surpassed in "the beauty of holiness" all temples ever built by man. In the Christless wars of Christendom the beautiful House of God had been deserted, and, like the palace of the Sleeping Beauty in another legend, had been gradually in the course of years surrounded by an impenetrable forest, so that its very site came to be forgotten. Still the tradition of its surpassing beauty lingered in the memory of Christendom. Learned divines and antiquaries wrote many an elaborate treatise in defence of different theories about its locality. The search for it beeame another quest of the Holy Grail, in which knightly warriors wasted their lives in vain. It was not by mere theorising or by warlike adventure, it was by doing a little bit of humble labour for the improvement of God's world to make it a more habitable home, that the ideal Church was to be found. A poor woodman, who had been toiling patiently at the clearing of the forest, paused amid his toil one day to wipe the honest sweat from his brow; and, as he looked down the opening which his labour had made, there stood before his eyes the glorious vision which learning and chivalry had sought in vain. 


\section{GENERAL INDEX}

A DAMs, John Conch, 19.

Age, Golden, 145.

Alcoholic craving, 150 .

Alexandria, 5 .

Altruisnı, 30, 91, 118, 130.

Ambrose, 6.

Anabaptists, 286.

Anæsthetics, 209.

Anarelism, 138, 269.

Anchoret, 228.

Anger, 210.

Animals, kindness towards, 63 .

Antigone, 76.

Antinomianism, 179.

Antioch, 4.

Antisthenes, 200, 206.

Apollonius Tyanensis, 85, 243.

Aquinas, 26.

Aratus, 83.

'A $є \tau$ 'ं, 83, 121, 181.

Aristotle, $21,73,74,76,77,78$, $87,88,92,116,117,162,185$, $195,198,199,200,211,213$, $218,232,276,284,296,307$.

Arnold, Matthew, 160, 161.

Artemis, 310.

Asceticism, 187-191, 308-310.

Athletics, 307.

Atom, 28, 231.

Augustine, 83, 134, 139, 176, 182, 209.

Aurelius, 82.

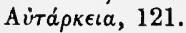

Authority, basis of, 12, 13.

Avarice, 296.

Baldeusperger, 164.

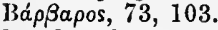

Barclay the Quaker, 244, 246, 247.

Barnabas, 286.

Baur, F. C., 101.
Beneficentia, 84 .

Benignitas, 84.

Bíos, 122.

Bossuet, 13.

Bribery, 274.

Bruce, W. S., 49.

Buddlism, 63, 146.

Burns, Robert, 215.

Butler, Bishol', 32, 116, 218.

Calvin, 58.

Calvinism, 136-144, 157.

Cardinal virtues, 6 .

Carlyle, 35, 117, 163, 200, 261, 278 .

Casuistry, 311-315.

Cebes, 117, 131, 164, 206, 212, 218.

Charism, 181.

Chrysippus, 83.

Cicero, 6, 44, 82, 84, 198, 211, 232.

Claudian, 219, 276.

Cleanthes, $83,206$.

Communism, 87, 88, 286.

Compromise, 273.

Continuity, law of, 171.

Cowell, Professor, 152.

Cynics, 196, 309.

Death, dance of, 215 .

Death, fear of, 213-216.

Defoc, 136.

Demonax, 219.

Descartes, 18, 129.

Determinate Obligation, 45 .

Deutsch, E., 64, 66, 67.

Diderot, 261.

$\Delta \iota \kappa a \iota$ óv $\eta, 77$.

Dio Chrysostom, 88.

Diogenes Lïertius, 74, 87, 200.

Diogenes the Cynic, 73. 
Disinterested, 30 .

Dissolute, 130 .

Dohschiitz, Von, 10, 180, 256.

Dorner, 16, 206.

Drummond, Henry, 30, 174.

Eecc Homo, 201, 217.

Eeclesiasticus, 51, 225.

Edwards, Jonathan, 157.

Egoism, 30, 91, 118, 130.

Election, 205.

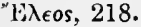

'E $\lambda \epsilon v \theta \epsilon \rho t \delta \tau \tau \eta s, 79$.

Eliot, George, 20.

Empedocles, 146.

End, as distinguished from means, $2,3$.

Epicureans, 5, 87.

Epicurus, 87.

'Е $\pi$ เє

'E $\pi \iota \theta v \mu l a, 198$.

Equality, 31.

Equity, 76, 78 .

Ethics, etymology of, 261.

Eudemonism, $11 \%$.

Ewald, 56, 62.

Falstaff, 163.

Farnell, 85, 86.

Fatalism, 156.

Fitzgerald, 152.

Fraternity, 31 .

Frederiek the Great, 288.

Friendship, 85-89.

Gallio, 99.

Gamaliel, 68.

Gambling, 280-283.

Gass, 49.

Geneva, 58.

Gentiles, 59 .

Goethe, 26.

Golden rule, 65-67.

Grant, Sir Alex., 78, 197.

Gregory Thaumaturgus, 5, 6 .

Gymnastics, 307.

Habit, 33, 146, 292.

Hamilton, Sir W., 1, 157 .

Harnaek, 249.

Hatch, 5, 82.

Hedonism, 117.

Hegel, 129, 143.
IIerakleitos, 192.

Heredity, 120.

Herod Antipas, 67.

Hillel, 65, 66, 258.

Hobbes, 66, 140, 232.

Homer, 211.

Hospitality, 56, 85 .

Humanisnı, 130.

Humanitas, $83,84$.

liume, $17,18$.

Hurons, 119.

Iago, 162.

Ibsen, 12.

Idlealism, personal, 130 .

Indeterminate Obligation, 45.

Individual, the, 28, 29, 230-236.

Individualism, 152 .

Indulgences, 167, 249, 305.

Inhuman, 296.

Instinct, 33, 146, 153, 292.

James, William, 3, 35, 138, 143, $171,173,184,240$.

Jansenists, 140.

Jesuites, relations des, 136.

Jodl, 184.

Joseph of Arimathea, 67.

Josephus, 71.

Jost, 66.

Jus Talionis, 92.

Justitia, 84 .

Juvenal, 59.

Kant, 19, 20, 129, 196, 225, 316.

líeats, 19.

Keble, 229.

Knowledge, 222-224.

Law, distinguished from Morality, 69.

Lessing, 214.

Leverrier, 19.

Liberality, 79, 84.

Liberty, 31.

Link, the missing, 145.

Livy, 233.

Longfellow, 168.

Lost Church, legend of the, 320 .

Loyalty, 241-243.

Lucian, 88, 101, 215, 219.

Lucretius, 214.

Luthardt, 49 . 
Macedonian conquests, influence of, $52,59,80$.

Makarism, 117.

Manchester Sehool, 138.

Materialisin, 156.

Matriarchal Society, 237.

M $\eta \delta \dot{\epsilon} \nu ~ \not ̋ \gamma a \nu, 307$.

Menander, 44.

Menenius Agrippa, 233.

Metávoca, 169.

Mill, J. S., 8, 35, 36, 129, 157.

Miller, Hugh, 137.

Nilton, 144, 162, 186, 195.

Miser, the, 296.

Monasticism, 228.

Montague, E. R., 64 .

Morality, distinguished fronı Law, 69.

Morals, etymology of, 261.

Miiller, Julius, 146.

National religion, 58.

Natural, distinguished from normal, science, 1.

Naturalism, 156.

Nature, 132.

Nature, philosopliy of, 233.

Naturreligionen, 53.

Necessity, plilosophical, 157.

Neighbour, 55.

New England eolonies, 58.

Newnian, F. W., 173.

Nieodemus, 67.

Nietzsche, 12, 20, 130, 144, 162.

Nihilism, 138.

Nitzseh, 16.

Novalis, 34, 35, 161.

Obligation, 45.

Occasionalism, 188.

Olymıjie games, 307.

Ontar Khayyan, 152.

Organisation, 189, 231.

Origen, 5.

Otherism, 30.

Overman, 130, 162.

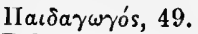

Paley, 34.

Panætius, 6, 84.

Pantheism, 156.

Papacy, 13.

Paradise, the lost, 144, 145 .
Parallelism, 188.

Parker, Theodore, 138.

Parkman, 119.

Pascal, 140.

Patriarchal Soeiety, 237.

Paul, 68, 139.

Peabody, Prof., 259, 278.

Pelagius, 134.

Perfeetionism, 24, 117.

Perseverance of the Saints, 205.

Pliædo, 164.

Plarisees, 64-67.

Phidias, 88.

Pigou, 9.

Plato, 5, 50, 73, 74, 77, 86, 97, $131,146,185,198,211,232,284$.

Pluralism, 130, 146.

Plutarch, 215, 310.

Pope, Alex., 42, 43.

Pragmatism, 19, 130.

Predestination, 156, 157.

Pre-existence, 148-150.

Prometheus, 161.

Prophets, Hebrew, 71.

Protestantism, 13.

$\Psi v \chi \dot{\eta}, 122$.

Puflendorf, 66.

Puritanism, 309.

Pyrrlio, 17.

Pythagoras, 211.

Pythagoreans, 86, 87, 92, 146.

Quakerism, 244.

Raslidall, 146, 311.

Regret, 165 .

Remorse, 165-168.

Resentment, 210.

Retaliation, 92-99.

Revolution, the Freneh, 137.

Right, 46.

Righteousness, 77.

Robinson Crusoe, 136.

Rodkinson's Translation of the

Talmud, 64, 65, 66 .

Roman eonquests, influence of, 80 .

Romanes, 295.

liothe, 16, 24.

Rousseau, 135, 136, 142-145.

Royce, Prof., 242.

Sapientia, 222.

Satan, 162. 
Satire, 208, 209.

Savares, 136.

Scepticism, philosophical, 17.

Sehleiermacher, 16.

Scottish School, 157.

Seltish, 30, 116.

Selfism, 30.

Self-love, 116.

Seneca, 84, 99, 232.

Sermon on the Mount, 91 .

Shakespeare, 125, 162, 312.

Shammai, 65.

Shaw, Bernard, 11, 101.

Sheldon, W. L., 196.

Sidgwick, 66, 181.

Sin, 155-163.

Sin, original, 151.

Slavery, 62.

Smith, J. M. P., 119.

Socrates, $73,86,97,164,211$, 232.

Son of Man, 105-106.

¿ooía, 222.

Sophist, 224.

Sophocles, 76.

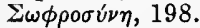

Spartans, 309.

Spencer, H., 233.

Spinoza, 167, 184.

Splendida vitia, 183.

Stapfer, 66.

Starbuck, 155, 171.

Statius, 218, 219.

Stephen, Sir L., 33.

Stewart, Dugald, 116.

Stickler for trifles, 273, 312.

Stirling, Hutchison, 129.

Stoics, 5, 79-85, 134, 142, 145, 172, 182, 196, 200, 206, 256.

Stranger, 55.

Strong's Bampton Lectures, 181, 222.

Sub-conscious or subliminal activity, 171.

Supererogation, works of, 304 .

Superman, 130.

Tacitus, 53, 54, 59.

'Tarde, G., 41, 232.

Temper, 210.
Tennyson, 34, 125, 128, 168, 194, $204,209$.

Terence, 44, 83.

Terminology of Ethics, 181.

Tertullian, 101.

Theocracy, 58.

Theognes, 78 .

Thucydides, 211.

'Tobit, Book of, 66 .

Tolstoi, 11, 269.

Transmigration of souls, 63 .

Trench, Arehbishop, 246.

Tribal morality, 56, 118-120, 151, 234.

Ullhorn, 189.

Ullmann, 249.

Unselfish, 30 .

Vice, 155.

Virgil, 56, 85, 211, 215, 262.

Vis medicatrix nature, 128.

Wage-earners, 61.

Wagner, 12.

Wallon, 62.

Wealth, 278.

Werenfels, 13.

Westermarck, 252.

Whitman, Walt, 123, 143.

Wild-oats metaphor, 193.

Will, 154, 157-163.

Wisdom, 221-224.

Wisdom of Solomon, 51.

Wordsworth, 125, 146, 173.

Wrong, 155.

Wuttke, 16, 49.

Wycliff, 112.

Xenophon, 86, 97, 211.

Zeller, 83.

Zeno the Stoic, 83.

Zens Philios, 85, 88.

Zens Xenios, 85 .

Ziegler, 4, 6, 49.

Zigliara, Cardinal, 257.

Zi $\boldsymbol{\prime}^{\prime}, 122$.

Zoolatry, 53. 


\section{INDEX OF SCRIP'TURE PASSAGES}

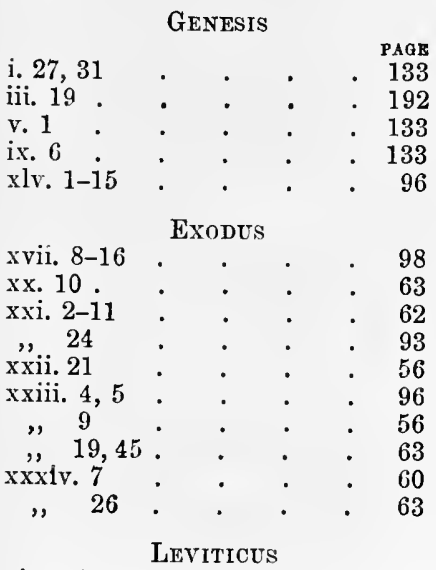

xix. $16-18,34 \quad$. $\quad . \quad 56$

, $17,18 . \quad . \quad . \quad 96$

xxii. $27,28 . \quad$. $\quad . \quad$. $\quad .63$

xxiv. 17-22. . . . 93

xxx. 41-55 . . . . 62

Numbers

vi. $4-9$

x. $12,13 \cdot \cdot \cdot 37$

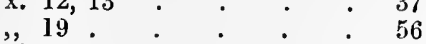

xi. $13 \quad . \quad . \quad . \quad . \quad 37$

xiv. $21 \quad . \quad . \quad . \quad .63$

xix. $21 \quad . \quad . \quad . \quad .93$

xxii. $6,7 \quad . \quad . \quad . \quad 63$

xxiv. $14,15 \quad \cdot \quad \cdot \quad \cdot 62$

,, $16 \quad . \quad . \quad . \quad .119$

,$\quad 19-21 \quad . \quad 61$
Deuteronomy-continued

xxv. 3 PAGE

, $4 \quad . \quad . \quad .62$

, 17-19 . . . . $\quad .98$

xxxi. $6,7,23 \quad$. $\quad . \quad 212$

Josmua

i. $6,9,18$. . . 212

vii. $\quad . \quad . \quad . \quad . \quad 119$

х. 25 . $\quad . \quad$. $\quad .212$

1 SAMUEL

xxiv. 7-22 • . . . 96

2 Kings

vi. 21-23 . $\quad$. $\quad$. $\quad .96$ xiv. 6 . $\quad . \quad . \quad . \quad 119$

xxii. 13 . . . . 212 xxviii. $20 \quad$. $\quad . \quad$. 212

2 Chroniches

XXv. $4 \quad . \quad . \quad 119$

ESTHER

ix. $13,14 \quad$. $\quad$. $\quad 119$

xxxi. 29,30 JoR $\quad$ • $\quad$. 96

iv. 5. PSAlMS . 217

vii. 4 , う $\quad \cdot \quad \cdot \quad \cdot \quad \cdot \quad \cdot \quad 96$

xxxiv. $8 \div 222$

xl. $12 . \quad$. . . 166,248

li. $5 . \quad . \quad . \quad . \quad 139$

, $10 . \quad . \quad 170$

xcii. $7 . \quad . \quad .276$

$\operatorname{cxxx} 4 \quad . \quad . \quad . \quad .179$

cxxxix. 7-12 . . . 317 


\section{INDEX OF SCRIPTURE PASSAGES}

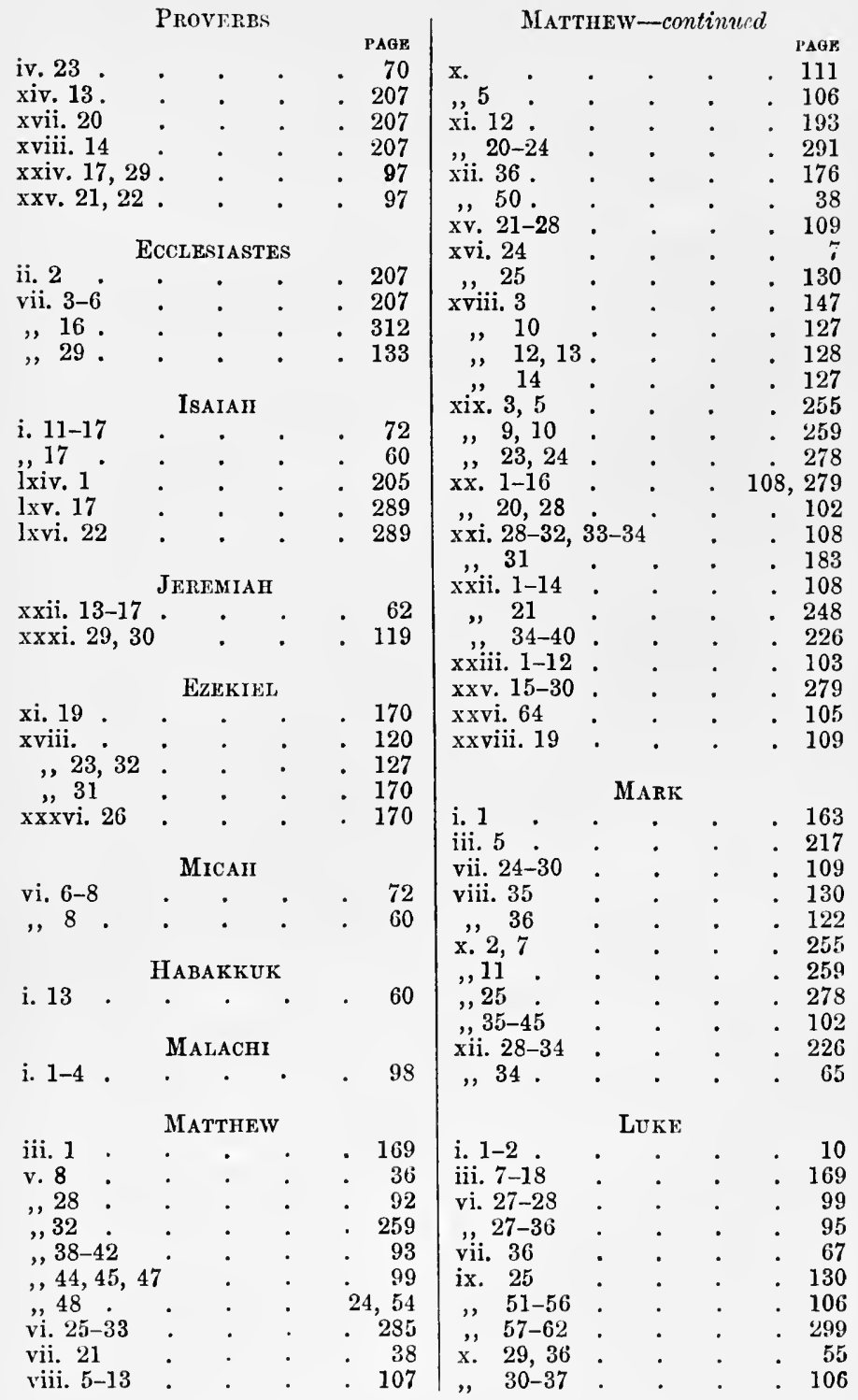




\section{INDEX OF SCRIPTURE PASSAGES}

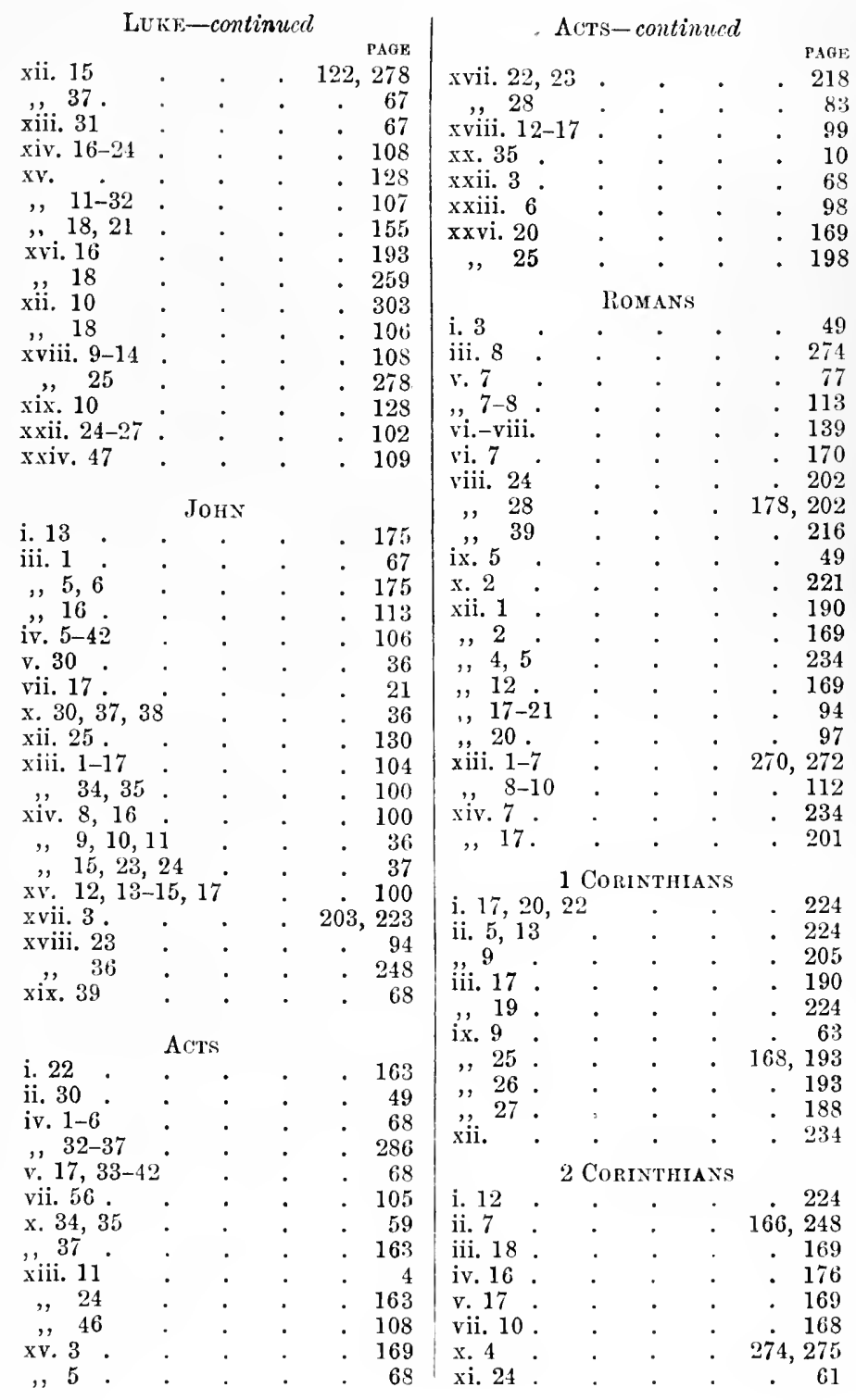




\section{INDEX OF SCRIPTURE PASSAGES}

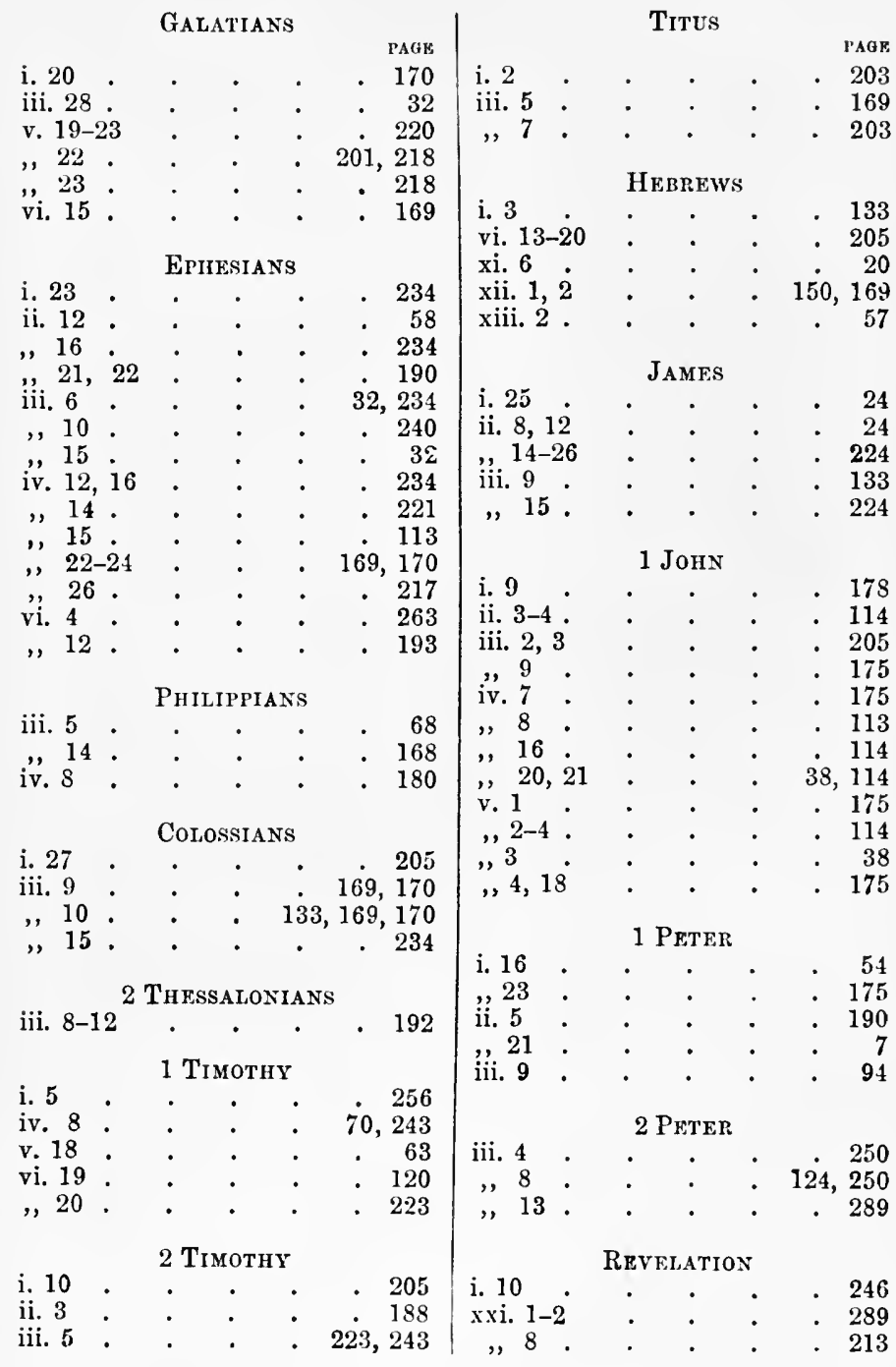


IN PREPARATION.

THE NEW

\section{DICTIONARY OF THE BIBLE.}

COMPLETE IN ONE VOLUME.

\section{J A M ES HAST I N G, D.D.}

This Dictionary is entirely distinct from the Five-Volume Dictionary.

It is complete in ONE Volume.

The Articles are all new.

Many of the Authors are the same as in the large Dictionary, but they have not written on the same Subjects.

It is not based on any other Dictionary, but is a wholly new and original Work.

Every Article is signed by the Author. This is the first time that all the Articles in a single-volume Dictionary of the Bible have been committed to Specialists and bear their signatures, as in the largest Dictionaries.

The price of the large Volume ( 800 or 900 pages), in handsome Cloth Binding, will be 20s; net.

Prospectus, with Specimen Page and List of Authors, post free on application.

The Religious Teachers of Greece. The Gifford Lectures. By the late James Adam, M.A., Litt.D.(Camb.), LL.D., Fellow, Lecturer, and Senior Tutor of Emmanuel College, Cambridge. Edited, with a Memoir, by his Wife, Adela Marion Adam. Now ready, demy $8 \mathrm{vo}$, price $10 \mathrm{~s}$. 6 d. net.

Contrints:--The Place of Poctry and Philosophy in the Development of Greek Religious Thought-Homer-From Hesiod to Bacehylides-Orphic Religious Ideas-Pindar-Eschylus-Sophocles-From Thales to Xenophanes-Hera. clitus-From Parmenides to Anaxagoras-The Age of the Sophists-Euripides -Socrates-Plato: His Cosmological Doctrine, His Elements of Asceticism and Mysticism, His Theory of Education, His Theory of Idcas.

'Discourses full of ripe learning.'-Scotsman.

'The work of one of the best Platonic scholars of this generatiou.'-Church Fimily Newspaper. 
The Book of Ecclesiastes. By Gaorge A. Barton, Ph.D., Professor of Biblieal Literature and Semitie Languages, Bryn Mawr College, U.S.A. (Now Volume, 'International Critical, Commentary.') Just published, price 8s. 6d.

Contents :-Name of the Book-Place in the Hebrew Biblc-Canonicity-TextHistory of the Interpretation-The Relation of 'QoneLETH' to Greek Thought -The Integrity of Ecclesiastes-Qoheleth's Thought in Outline-Was Qoheleth written in Metrical Form?-Linguistic Characteristics of Qoheleth - The Relation of Ecclesiastes to Ben Sara-The Attitude of the Book of Wisdom to Ecclesiastes-Date and Authorship-Commentary.

The Christian Minister and his Duties. By Rev. J. Oswald Drkes, D.D., Westminster College, Cambrilge.

\section{The Teaching of Christ in its Present Appeal. By} Rev. W. L. WaLker, Author of 'The Cross and the Kingdom,' etc. New and Revised Edition, price 2s. 6d. net.

'Mr. Walker, well known by his other great books, has written a really helpful edifying, and inspiring little book. He brings us into the very room where Christ is. We hear His voice.'-Expository Times.

\section{Prehistoric Archæology and the Old Testament. By}

Rev. H. J. Dukinfield Astuer, D.Litt.,' Vicar of Rudham, Norfolk. Post 8 vo, priee 5s. net.

'Is worthy throughout of careful study.'- Spectutor.

'The author writes from secure and first-hand kuowledge.'-Aberdecn Free Pross.

The Grammar of Philosophy. A Study of Scientifie Method. By David Graitam, Barrister-at-Law. Post 8vo, price 7 s. 6d. net.

\section{No Struggle for Existence, No Natural Selection. A} Critical Examination of the Fundamental Principles of the Darwinian Theory. By George P'aulix, Edinburgh. Post 8vo, price 5s. net. 
T. \& T. ClaAk's Publications.

SOMETHING ENTIRELY NEW.

NEYER ATTEMPTED BEFORE.

-A triumphant and unqualified success. Indispensable to ministers and Bible students.'-Dr. W. RoBretson NicolL.

\section{NOW COMPLETE IN TWO VOLUMES A DICTIONARY OF CHRIST AND THE GOSPELS.}

\section{Edited by J. HASTINGS, D.D.}

Price per Vol., in cloth binding, 21s. net; in half-morocco, gilt top, 26s. net.

The purpose of this Dictionary is to give an account of everything that relates to Christ-His Person, Life, Work, and Teaching.

It is first of all a preacher's Dictionary. Its authors are preachers as well as scholars.

The articles are all new. Even when their titles are the same as the titles of articles in the 'Dictionary of the Bible,' they are written by new men, and with a new purpose.

The articles are not entirely limited to the Bible, but gather together whatever touches Christ in all the history and experience of the Church.

It is called a Dictionary of Christ and the Gospels, because it includes everything that the Gospels contain, whether directly related to ChRIsT or not. Its range, however, is far greater than that of the Gospels. It seeks to cover all that relates to Christ throughout the Bible and in the life and literature of the world. There are articles on the Patristic estimate of Jesus, the Mediæval estimate, the Reformation and Modern estimates. There are articles on Christ in the Jewish writings and in the Muslim literature. Much attention has been given to modern thought, whether Christian or anti-Christian. Every aspect of modern life, in so far as it touches or is touched by Christ, is described under its proper title.

It will be found that the contents of the Gospels, especially their spiritual contents, have never before been so thoroughly investigated and set forth.

'The preacher's purpose is better served than it has ever been before.'-Times.

'A scholarly production, edited with admirable skill.'-Christian World.

'Valuable for all scholars and students, it should prove invaluable for the preacher. - Methodist Times.

'We know of no book likely to be more helpful to the parochial clergy.'-Guardian.

'Invaluable to preachers and teachers, and ought to be in constant use.'-Churchman. 


\section{The ênternational Theologiral ådibrarm.}

EDITED BY

Principal S. D. F. SALMOND, D.D., and Professor C. A. BRIGGS, D.D.

'A valuable and much-needed addition to the theological literature of the Englishspeaking nations.'-Academy.

The First Fifteen Volumes are now ready, in Post 8vo, viz, :-

\section{An Introduction to the Literature of the Old Testa-} ment. By Professor S. R. Driver, D.D., Oxford. Seventh Edition. Price 12s.

The Guardian says: 'By far the best account of the great critical problems connected with the Old Testament that has yet been written. . . . It is a perfect marvel of compression and lucidity combined.'

Christian Ethics. By Newman Smyth, D.D. Third Edition. Price 10s, 6d.

The Bookman says: 'It is the work of a wise, well-informed, independent and thoroughly competent writer. It is sure to become the text-book in Christian Ethics.'

\section{Apologetics; or, Christianity Defensively Stated.}

By the late Professor A. B. Bruce, D.D., Glasgow. Third Edition.

Price 10s. 6d.

The Expository Times says: "The force and the freshness of all the writings that Dr. Bruce has hitherto published have donbtless led many to look forward with eager hope to this work ; and there need not be any fear of disappointment.'

History of Christian Doctrine. By Professor G. P. Fisher, D.D., LL.D., Yale. Second Edition. Price 12s.

The Critical Review says: 'A clear, readable, well-proportioned, and, regarding it as a whole, remarkably just and accurate account of what the course and development of doctrine throughout the ages, and in different countries, has been.'

\section{A History of Christianity in the Apostolic Age. By Professor A. C. McGiffert, Ph.D., D.D., New York. Price 12s.}

The Literary World says: 'A reverent and eminently candid treatment of the Apostolic Age in the light of research.'

Christian Institutions. By Professor A. V. G. Allen, D.D., Cambridge, U.S.A. Price 12s.

The Christian World says: 'Unquestionably Professor Allen s most solid performance ; and that, in view of what he bas al ready accomplished, is saying a great deal.' 
Volumes now ready (continued)-

The Christian Pastor and the Working Church. By Washington Gladden, D.D., LL.D. Price 10s. 6d.

The Baptist Magazine says: 'There is scarcely a phase of pastoral duty which is not touched upon luminously and to good purpose.'

Canon and Text of the New Testament. By Professor Caspar René Gregory, D.D., LL.D., Leipzig. Price 12s.

\section{The Theology of the New Testament. By Professor} G. B. Stevens, D.D., Yale. Price 12s.

'The Guardian says: 'No less than an encyclopødia of the teaching of the Now Testament. Within the covers of a single volume we have not merely a summary of Christ's teaching in the Gospels, but a luminous analysis of each of the Epistles which every clergyman will find of the utmost value. . . . It is a work which no one of the clergy can afford to neglect.'

The Ancient Catholic Church. From the Accession of Trajan to the Fourth General Council [A.D. 98-451]. By the late Principal RaInr, D.D., Edinburgh. Price 12s.

The Expository Times says: 'This work will give the intelligent reader more insight iuto the heart of the situation than a dozen books more systematically planned, and more laden with learned detail.'

Old Testament History. By Professor Henrry P. Smith, D.D., Amherst. Price 12s.

The Academy says: "The history of the little nation out of which was to arise the Sun of Righteousness, is clothed with an added charm of actuality, as it is presented in these sano and balanced pages.'

The Theology of the Old Testament. By the late Professor A. B. Davidson, D.D., LL.D., Edinburgh. Second Edition. Price 12s.

The Bookman says : ' Oontains the essence and strength of the whole work of one whom the best judges have pronounced to be a leader in Old Testament learning.'

\section{The Christian Doctrine of Salyation. By Professor G. B.} Stevens, D.D., Yale. Price 12s.

The Expository Times says : ' It is a great book upon a great subject. If preachers want to tit themselves for a winter's work of strong, healthy, persuasive preaching, this book will fit them.'

History of the Reformation. By Principal T. M. Lindsar, D.D., Glasgow.

In Two Volumes-

VoL. I.-The Reformation in Germany, from its beginning to the Religious Peace of Augsburg. Second Edition. Price 10s. 6d.

VoL. II.--The Reformation in Lands beyond Germany. With Map. Price 10s. 6d. 


\section{The International eritical Commentary}

ON THE HOLY SCRIPTURES OF THE OLD AND NEW TESTAMENTS.

UNDER THE EDITORSHIP OF

The Rer. S. R. DRIVER, D.D., Oxford; the Rev. A. PLUMMER, M.A., D.D., Durham; and the Rev. C. A. BRIGGS, D.D., New York.

'T'he publication of this series marks an epoch in English exegesis.'-British Weekly.

Sixteen Volumes are now ready, in Post 8vo, viz.:-

Numbers. By Professor G. Buchanan Grat, D.D., Oxford. Price 12s.

Church Bells arys: 'Dr. Gray's commentary will be indispensable to every Englisb student.'

Deuteronomy. By Professor S. R. Driver, D.D., Oxford. Third Edition. Price 12s.

Prof. G. A. Sмiти says : 'The series could have had no better introduction than this volume from ite Old Testament editor. . . . Dr. Driver has achieved a commentary of rare learning and still more rare candour and sobriety of judgment.'

Judges. By Professor Georar F. Moore, D.D., Harvard University. Second Edition. Price 12s.

Bishor H. E. RYLE, D.D., says: 'I think it may safely be averred that so full and soientific a oommentary upon the text and subject-matter of the Book of Judges has never been produced in the English langaage.'

The Books of Samuel. By Professor Henri P. Smitr, D.D., Amherst College. Price 12s.

Literature eays : 'The most complete and minute commentary hitherto published.'

The Book of Psalms. By Professor C. A. Briggs, D.D., New York. In Two Volumes, price 10s. 6d. each.

'It is likely for some time to hold its place as at once the fullest and the most authoritative we possess on this book of Scripture. It enlances the value of "The International Critical Commentary," and it will also add to the already great reputation of its author.'-Principal Marcus DoDs, D.D., in the Bookman.

\section{The Book of Proverbs. By Professor C. H. Tor, D.D.,} Harvard University. Price 12s.

The Bookman says: "The commentary is full, though scholarly and businese like, and must at once take its place as the authority on "Proverbe."

The Book of Ecclesiastes. By Professor Grorge A. Barton, Ph.D., Bryn Mawr College, U.S.A. Price 8s. 6d. 
Volumes now ready (continued)-

Amos and Hosea. By President W. K. Harper, Ph.D., Chicago University. Price 12s.

'The Methodist Recorder says: 'For thoroughness and exoellence of workmanship, fur clearness of arrangement and exposition, and for comprehensiveness and accuracy in the handling of textual, grammatical, and exegetical questions, this work should rank among the foremost.'

\section{St. Matthew's Gospel. By Willoughby C. Allen, M.A.,} Exeter College, Oxford. Second Edition. Price 12s.

The Scotsman says: 'Mr. Allen has provided students with an invaluable introduction to the comparative study of the Synoptic Gospels. The work as a whole is a credit to English New Testament scholarship, and worthy to rank with the best products of the modern German school.'

\section{St. Mark's Gospel. By Professor EzRa P. Gould, D.D.,} Philadelphia. Price 10s. 6d.

The Baptist Magazine says: 'As luminously suggestive as it is conoise and sober. The commentary proper is thoughtful, judicious, and erudite-the work of a master in hermeneutics.'

\section{St. Luke's Gospel. By Rev. Alfred Plummer, D.D. Fourth Edition. Price 12s.}

The Guardian says: 'We feel heartily that the book will bring credit to English acholarship, and that in its carefulness, its sobriety of tone, its thoughtfulness, its reverence, it will contribute to $n$ stronger faith in the essential trustworthiness of the gospel record.'

Romans. By Professor William Sandat, D.D., LL.D., Oxford, and Principal A. C. Headuam, D.D., London. Fifth Edition. Price 12s.

The Bishop of ElY says: 'We welcome it as an epoch-making contribution to the study of St. Paul.'

Ephesians and Colossians. By Professor T. K. Аввотr, D.Lit., Dublin. Price 10s. 6d.

The Expository Times says: "There is no work in all the "International" series that is more faithful or more felicitous. . . . Dr. A bbott understands these Epistles $\rightarrow$ we had almont said as if he had written them.'

Philippians and Philemon. By Professor Marvin R. Vincent, D.D., New York. Price 8s. 6d.

'The Scotsman says: 'In every way worthy of the series which was so well commenced [in the New Testament] with the admirable commentary on the Romans by Dr. Sanday and Dr. Headlam.'

\section{St. Peter and St. Jude. By Professor Charlas Biga, D.D., Oxford. Second Edition. Price 10s. 6d.}

The Guardian says: 'A first-rate critical edition of these Epistles has been for a long time a felt want in English theological literature... this has been at last supplied l,y the labours of Canon Bigg. . . . llis notes are full of interest and suggestiveness.'

** A Prospectus, giving full details of the Series, with list of Contributors, post free on application. 
THE LATEST HISTORY OF THE REFORMATIQN.

'Principai Lindsay is unsurpassed as an authority on the history of the Reformation.'BRITISH WeEKLY.

A History of the Reformation. By Principal T. M. LiNDSAY, D.D., LL.D. In Two Vols., post 8vo, price 10s. 6d. each. Vol. I.-The Reformation in Germany, from its beginning to the Religious Peace of A ugsburg.

Vol. II. - The Reformation in Lands beyond Germany (Switzerland, France, The Netherlands, Scotland, and England; the Anabaptist and Socinian Movements; The Counter-Reformation). With Map of the Reformation and Counter-Reformation (1520-1580).

'The best English History of the Reformation in Germany. A decidedly successful book.'-Professor Pollard, in the Tribune.

'There can be no doubt this will be the classical work in English on the Reformation. ... It is a noble crown of a life's study of the most stupendous spiritual movement since the death of St. Paul. Dr. Lindsay writes with an ease and charm that fasciuates the reader and carries him on from page to page until the end.'-Christian I'orld.

'At last the English public possesses an adequate History of the Reformation. The work is planned with great comprehensiveness, and executed with singular balance of thought and impartiality. It represents immense labour, with learning of nost unusual breadth and depth.'-The Times.

Christian Theology in Outline. By Professor W. Apass Brown, Ph.D., D.D., Union Theological Seminary, New York. Demy 8vo, price 7s. $6 \mathrm{~d}$. net.

'Of recent books on Christian Theology, this new work is in many respects the lest. It is alive to the present intellectual conditions, and speaks in the language of the time. It is an excellent handbook for a theological class, and there must be thousands of nonprofessional readers also who will find it an absorbing and profitable study.... Everywhere the sincere, cantious, and responsible utterance of a man who has often been orer the field, and who knows what he is doing.'-British Weekly.

\section{The Growth of Christian Faith. By Rev. Georar Frrirs,} D.D., Cluny. 8 vo, 7 s. 6 d. net.

Summary of Contents:-Part I. Thb Preparation for Rkligion. Part II. Riuigion as an Established Fact of Life. Part III. Forgiveniss throvgi Christ. Part IV. Historical. Part V. Development of Results.

'We know of no work in English exactly like it. ... The whole of this rich and fertile work demands, and we think will receive, close attention. Dr. Ferries in writing it has conferred a great benefit npon all open-minded lovers of Christian truth.'-Christian World.

The Fatherhood of God in Christian Truth and Life. By the Rev. J. Scotr LidGETt, M.A., Warden of Bermondsey Settlement. $8 \mathrm{vo}, 8 \mathrm{~s}$. net.

This book is an attempt to estabiish the fatherhood of God as the determining fact of Christian life and the determining principle of Christian Theology. Among the subjects dealt with are: The New Testament Doctrine of the Fatherhood of God. Place in New Testament Theology. The Relation of the Old Testament Doctrine to the Fatherhood of God. The Doctrine in Church History. Vaijity and Content. Manifestation.

- Every reader will own the masterly skill with which Mr. Lidgett handles his snbject, the breadth of his reasoning, the wide knowledge which he brings to bear on overy page of his work, and the zeal which fuses and transfuses the whole.'-Methodist Recorder.

- A valuable contribution to the study of a very great doctrine.'-Guardian.

To Christ Through Criticism. By Richard W. Seaver, M.A., B.D., Belfast. In post 8 vo (212 pages), price 3s. 6 d. net.

'The work of a scliolarly, thoughtful, and broad-minded man. Pleasant to read, simple, and judicious.'-Church Family Newspaper. 


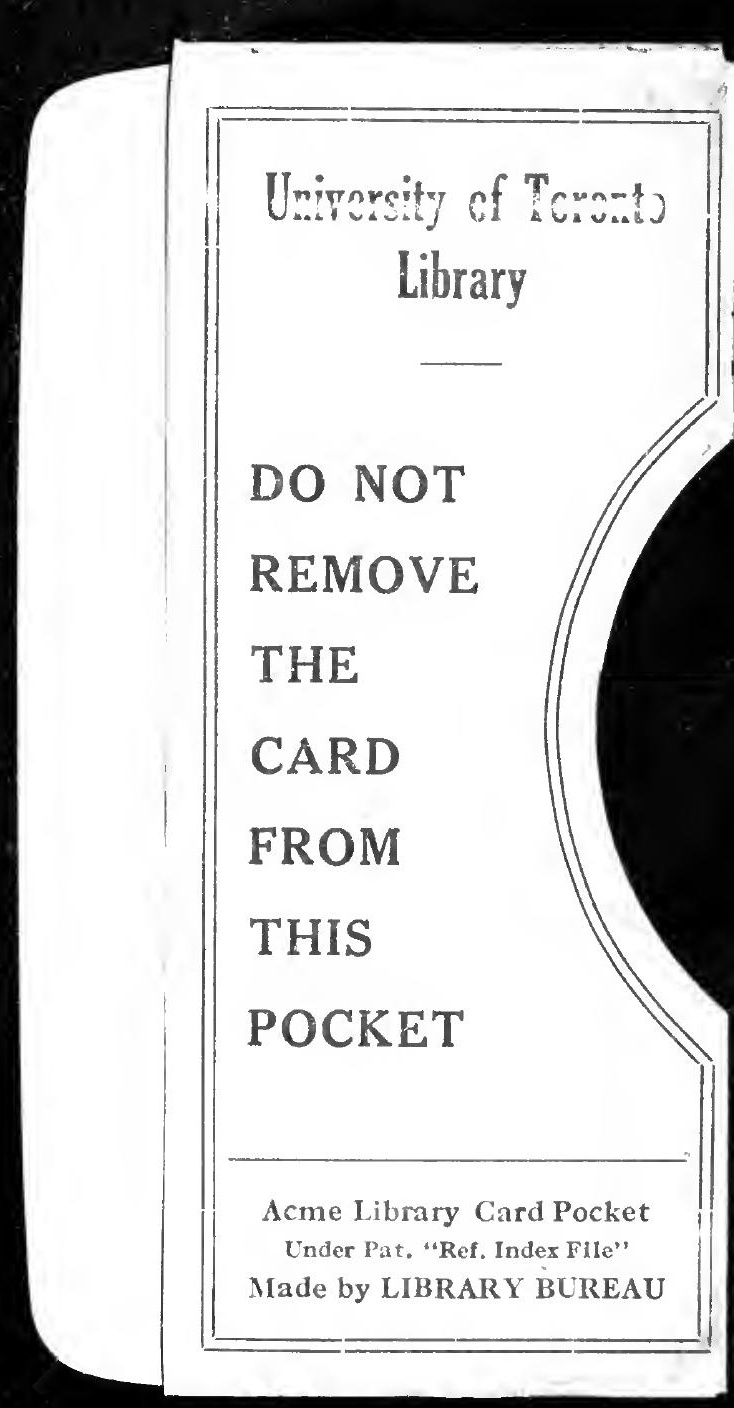


